\title{
Ārstēšanas rezultātu salīdzinājums pēc spieḳkaula distālo artikulāro lūzumu osteosintēzes ar artroskopiski kontrolētām iekšējās un ārējās fiksācijas metodēm
}




\title{
RīGAS STRADIN,A \\ UNIVERSITĀTE
}

Uldis Krustiņš

ORCID 0000-0001-7184-8605

\section{Ārstēšanas rezultātu salīdzinājums pēc spieḳkaula distālo artikulāro lūzumu osteosintēzes ar artroskopiski kontrolētām iekšējās un ārējās fiksācijas metodēm}

\author{
Promocijas darbs zinātniskā doktora grāda \\ "zinātnes doktors (Ph.D.)" iegūšanai
}

Nozare - klīniskā medicīna

Apakšnozare - ortopēdija

Promocijas darba vadītājs:

Profesors Andris Jumtiṇ̌s, Rīgas Stradiṇa universitāte, Latvija

Zinātniskais konsultants:

Dr. med. Mārtiṇš Kapickis, Latvijas Mikroḳirurgijijas centrs

Rīga, 2021 


\section{Anotācija}

Spieķkaula distālo galu lūzumi ir visbiežākā kaulu trauma, ar kuru cilvēki vēršas pēc palīdzības medicīnas iestādēs, to sastopamība variē no 20 līdz $30 \%$ visu lūzumu. (Ilyas and Jupiter, 2007; MacIntyre and Dewan, 2016). Šie lūzumi ir satopami visās vecuma grupās un abu dzimumu pacientiem, taču ir novērojams bimodāls sadalījums starp dzimumiem un pacientu vecumu - biežāk traumējas jauni vīrieši, iegūstot sarežğītus, artikulārus lūzumus, un vecāka gadagājuma sievietes, kurām bez kaula lūzuma novēro arī dažādu stadiju osteoporotiskās izmaiņas traumētajos kaulos. Lielākā daḷa šo lūzumu ir salīdzinoši vienkārši ekstraartikulāri, nedislocēti vai minimāli dislocēti un ārstējami konservatīvi, bet apmēram 30-40 \% lūzumu ir artikulāri (Koo et al., 2013; Sander et al., 2018), kuru rezultātā nepieciešama bojāto kaula locītavu virsmu atjaunošana maksimāli tuvu anatomiskajam stāvoklim, lai radītu iespēju vislabāko funkcionālo rezultātu sasniegšanai adekvātas rehabilitācijas gadījumā.

Līdz pagājušā gadsimta astoņdesmitajiem gadiem nebija noteikti un pierādīti kritēriji artikulāro spieķkaula lūzumu veiksmīgai ārstēšanai. Nereti sarežǵītu lūzumu ārstēšana netika veikta adekvāti mūsdienu izpratnei, jo nebija pieejami multipluss fragmentus fiksējoši implanti, kā arī pastāvēja uzskats, ka šādu lūzumi veiksmīga ārstēšana ir apšaubāma. 1986. gadā J. L. Knirk un J. Jupiter publicēja ikonisko rakstu par pētījumu spieḳkaula distālo galu lūzumu ārstēšanā un to rezultātiem, kurš definēja lielāko piel̦aujamo artikulāro deformāciju variantus, lai pacientam novērstu vai mazinātu posttraumatiskās deformējošās osteoartrozes (DOA) veidošanās riskus. Tika secināts, ka 91 \% artikulāro lūzumu, kuriem pēc repozīcijas locītavas virsmas longitudinālā nobīde saglabājas lielāka par $1 \mathrm{~mm}$, un 100 \% lūzumu ar longitudinālo nobīdi virs $2 \mathrm{~mm}$ komplicējas ar deformējošu osteoartrozi (Knirk and Jupiter, 1986). Nākamajās desmitgadēs tika radīti implanti un jaunu ārstniecības metožu apraksti spieḳkaula distālo galu artikulāro lūzumu ārstēšanai. Pēdējo dekāžu laikā ir nostabilizējušies divi svarīgākie spieķkaula distālā gala artikulāro lūzumu ārstēšanas principi - vaḷēja osteosintēze ar volāro bloḳēto plāksni (VLP-volar locking plate), kas nodrošina maksimālu subhondrālā kaula slāņa atbalstu un stabilu fiksāciju, kā arī slēgta vai minimāli invazīva repozīcija fluoroskopijas kontrolē un fiksācija ar ārējās fiksācijas aparātu (ĀFA - EF-external fixator), lūzumiem, kuriem dažādu iemeslu dēl nevar tikt lietota fiksācija ar VLP.

Ir virkne rakstu, kuros apgalvo, ka spieķkaula lūzumu fiksācija ar VLP uzrāda labākus vēlīnos rezultātus (Esposito et al., 2013; Franceschi et al., 2015; Richard et al., 2011; Wilcke et al., 2011; Williksen et al., 2013; Wright et al., 2005; Xie et al., 2013), savukārt citos tiek pierādīts, ka labāki rezultāti ir, lietojot ĀFA un stieples (Kapoor et al., 2000) (Pino et al., 2011). Literatūrā atrodamie metaanalīžu pētījumu rezultāti par attiecīgajām tēmām arī ir pretrunīgi - 
ir pētījums, kurā pierādās labāki rezultāti, lietojot VLP metodi (Walenkamp et al., 2013), bet ir arī metaanalīzes pētījums, kurā neviena no metodēm neuzrāda statiski ticamas priekšrocības, salīdzinot ar otru (Margaliot et al., 2005).

Lai gan pirmā plaukstas locītavas artroskopija tika veikta 1979. gadā, šīs metodes strauja attīstība sākās tikai 1986. gadā, kad T. L. Whipple, pēc anatomiskajiem pētījumiem, publicēja drošu plaukstas artroskopijas portālu aprakstu (Whipple et al., 1986). Kopš tā laika ir publicēti daudzi pētījumi, kuri norāda uz artroskopiski asistētu spieķkaulu lūzumu operāciju rezultātu pārākumu pār fluoroskopiski kontrolētajām osteosintēzēm (Abe and Fujii, 2017; Doi et al., 1999; Freeland and Geissler, 2000; Lutsky et al., 2008; Ono et al., 2012; Ruch and Papadonikolakis, 2006; Varitimidis et al., 2008).

Latvijā plaukstas artroskopiskā ķirurğija tika ieviesta Plastiskās, rekonstruktīvās un mikroḳirurğijas centrā 2009. gadā. Kopš 2010. gada tika uzsāktas arī spieḳkaula distālo galu artikulāro lūzumu artroskopiski asistētas operācijas. Metode minimāli invazīvā tehnikā ḷauj verificēt locītavas virsmas lūzuma fragmentu precīzu pozicionēšanu, veikt papildu repozīciju un precīzu fragmentu fiksāciju ar dažādām osteosintēzes metodēm, kā arī atklāt papildu mīksto audu bojājumus (Chen et al., 2002; Guofen et al., 2005; Kamano et al., 2005; Lutsky et al., 2008; Ruch et al., 2004). Angliski rakstošajā medicīniskajā literatūrā, publiskajās datubāzēs līdz šim nav sastopami artroskopiski asistētu spieḳkaula distālo galu lūzumu dažādu ķirurǵiskās ārstēšanas metožu salīizinājumi.

Šajā pētījumā veikta detalizēta literatūras avotu analīze par spieķkaula distālo artikulāro lūzumu anatomiju, biomehāniku, morfolog̣iju, ārstēšanas metodēm un to pamatojumu, kā arī plaukstas artroskopijas kontrolē veikto operāciju pacientu subjektīvo un objektīvo datu apstrāde 1, 3, 6 un 12 mēnešus pēc veiktās ķirurǵiskās manipulācijas. Šis bija prospektīvs kohortas pētījums, kurā pacienti tika randomizēti, izmantojot alternatīvās allokācijas metodi, t. i., pirmajam pacientam lietota lūzuma fiksācija ar VLP, nākamajam - ĀFA, trešajam atkal VLP utt. Š̀̄ metode tika izvēlēta, lai maksimāli ātri iegūtu vienāda skaita salīdzināmās grupas. Kopumā divu gadu laikā tika veiktas 74 operācijas (38 operācijas VLP grupā un 36 operācijas ĀFA grupā). 4 pacienti VLP grupā un 6 pacienti ĀFA grupā dažādu iemeslu dēḷ neieradās uz visām novērošanas protokolā paredzētajām vizîtēm, un viṇu dati netika iekḷauti galējā analīzē. Kvalitatīvai datu apstrādei pētījuma beigās palika 34 pacienti VLP grupā un 30 pacienti ĀFA grupā. Pacientu subjektīvie un objektīvie dati tika izvērtēti, izmantojot standarta rentgenogrāfiju (RTG) operētajai plaukstas locītavai 2 projekcijās, Patient Related Wrist Evaluation (PRWE), Modern Activity Subjective Survey of 2007 (MASS07), Gartland \& Werley skalas, kā arī veicot objektīvo datu mērījumus - kustību apjoma (ROM), plaukstas 
satvēriena (Grip), atslēgas tvēriena (Pinch) un 3 pirkstu tvēriena (3P Pinch) rezultātu pierakstus.

Visā pētījuma periodā abu grupu pacientu objektīvie un subjektīvie rezultāti uzlabojās samērā vienlīdzīgi, ar nelielu pārsvaru VLP grupas pacientiem. ĀFA grupā konstatētās komplikācijas bija medicīniski nopietnākas, lai gan skaita ziṇā neatšḳ̄īās no VLP grupas komplikācijām. Lietojot artroskopijas metodi šajā pētījumā, papildu repozīcijas nepieciešamība pēc primārās lūzuma stabilizācijas abu grupu pacientiem bija nepieciešama biežāk, nekā tas bijis aprakstîts literatūrā iepriekš. Alternatīvās allokācijas metode, kura tika izvēlēta pacientu randomizācijai, atsevišķos gadījumos bija traucējoša, jo neḷāva lietot ķirurga izvēlēto ārstēšanas metodi, kura, iespējams, būtu bijusi pacientam piemērotāka.

Atslēgvārdi: spieḳkaula distālā gala lūzumi, plaukstas artroskopija, TFCC, ārējās fiksācijas aparāts, volārā bloḳējošā plāksne, rokas ķirurg̣ija, asociētie bojājumi. 


\section{Annotation}

\section{Comparison of volar locking plates with external fixation and $\mathrm{K}$-wires in arthroscopically assisted intra-articular distal radius fracture fixation}

Distal radius fractures (DRF) are one of the most common bone injuries presented in emergency rooms and varies from 20 to $30 \%$ of all fractures. (Ilyas and Jupiter, 2007; MacIntyre and Dewan, 2016). These fractures are presented in all age groups and both genders, but there is a typical bimodal distribution - more often young males with complicated injuries and older females with DRF and osteoporotic changes are observed. Most of distal radius fractures are simple, extraarticular, non-dislocated or minimally dislocated ones and can be treated conservatively. But up to 30-40\% of fractures nowadays are intra-articular ones (Koo et al., 2013; Sander et al., 2018), and require surgical restoration of the articular surfaces, to achieve the best possible functional result in a case of an adequate rehabilitation.

Until the 1980 `s, criteria for successful treatment of the articular DRF`s had not been established and demonstrated. Treatment of the complex DRF`s was not performed adequately, in modern understanding, because of the absence of implants for variable and multiple fragment fixation and also there was a perception that the successful treatment of such fractures is questionable. In 1986 J. L. Knirk and J. Jupiter published the iconic paper about the treatment results of the articular DRF in young adults and defined the maximum permissible articular gaps and step-offs to prevent or reduce the risk of posttraumatic deformative osteoarthrosis. They concluded that $91 \%$ of articular fractures with step-off more than $1 \mathrm{~mm}$ after the reposition and $100 \%$ of fractures with step-off more than $2 \mathrm{~mm}$ are complicated by deformative osteoarthrosis (Knirk and Jupiter, 1986). New implants and methods of the DRF treatment were developed during the next decades. Nowadays there are two main principles of the surgical treatment of DRF - open reduction and internal fixation with volar locking plate, which provides maximum support of the subchondral bone and a stable fixation. And the second one closed, minimally invasive reposition under the fluoroscope control and stabilization of the fragments with K-wires and external fixator, mostly in cases of fractures where volar locking plates cannot be used because of the fracture patterns.

There are many articles which claim that superior outcomes are achieved as a result of plating (Esposito et al., 2013; Franceschi et al., 2015; Richard et al., 2011; Wilcke et al., 2011; Williksen et al., 2013; Wright et al., 2005; Xie et al., 2013) and others which claim that external fixation and K-wire are superior (Kapoor et al., 2000) (Pino et al., 2011). The conclusions of published meta-analysis studies on this topic also are controversial Walenkamp et al. in 2013 published results of the superiority of the volar locking plate 
(Walenkamp et al., 2013), but Margaliot et al. in meta-analysis study published in 2005 did no find statistically significant differences between these two methods(Margaliot et al., 2005).

Although the first wrist artrhroscopy was performed in 1979, the rapid development of this method started only in 1986 when T. L. Whipple, after several anatomical studies, described the portal map for safe wrist artrhroscopy (Whipple et al., 1986). Since this was published, numerous studies have been published which confirm the superiority of arthroscopic reduction over the only fluoroscopically controlled surgeries (Abe and Fujii, 2017; Doi et al., 1999; Freeland and Geissler, 2000; Lutsky et al., 2008; Ono et al., 2012; Ruch and Papadonikolakis, 2006; Varitimidis et al., 2008).

Arthroscopic surgery of the wrist in Latvia was introduced in the Centre of Plastic, Reconstructive and Microsurgery in 2009. In 2010 the first arthroscopically assisted distal radius fracture surgery was performed. This method of treatment allows to verify the precise position of the fragments, evaluate the joint surface, perform precise fixation and detect additional soft tissue injuries with minimal invasiveness (Chen et al., 2002; Guofen et al., 2005; Kamano et al., 2005; Lutsky et al., 2008; Ruch et al., 2004). So far there is a lack of studies regarding the comparison of different arthroscopically assisted treatment methods of DRF's in English speaking data bases and medical literature.

This study presents a detailed analysis of the literature about the anatomy, morphology, biomechanics and treatment methods of the articular DRF`s and reasons for them, as well as a prospective comparison of subjective and objective outcomes, recorded 1, 3,6 and 12 months after the primary surgery, of the two methods of fixation, both in combination with arthroscopically assisted reduction of intra-articular fragments. This was a prospective cohort study, where patients were allocated into two groups using an alternate allocation method, the first patient undergoing surgery with VLP, the second one with an external fixator and $\mathrm{K}$-wires, the third one with VLP an so on. This method of the randomization was chosen to achieve the same and sufficient number of patients in both groups as quick as possible. During the 2-year study period, 74 surgeries were performed (38 in VLP group and 36 in EF group). Four patients in VLP group and six patients in EF group did not returned for scheduled followup and thus were excluded. Consequently only 34 patients from VLP group and 30 patients from EF group were included in the final data assessment. The results of treatment were assessed with X-ray examinations postero-anterior position in a $10^{\circ}$ tilted-view and lateral position in a $20^{\circ}$ tilted view, subjective evaluation using the Patient-Rated Wrist Evaluation (PRWE) score, Modern Activity Subjective Survey of 2007 (MASS07) score, and subjective and objective evaluation using the Gartland and Werley score. Grip / pinch / tripod-pinch strength and range of motion were also measured. 
The clinical parameters as well as subjective scores improved evenly during the 12 months following surgery, showing a small superiority in figures for the patients of VLP group. Number of complications was small and equal in both groups, but these ones in EF group were medically more serious than complications in the VLP group. The incidence of additional reduction of fracture fragments at arthroscopy in both groups was higher than found in literature. Alternate allocation method, which was chosen as a method of randomization in some cases made it difficult to fix fragments optimally and limited the surgeon to adapt the technique according to the complexity of the fracture type.

Keywords: intra-articular distal radiius fracture, wrist arthroscopy, volar locking plate, external fixator, k-wire fixation, associated injuries, wrist surgery, TFCC. 


\section{Saturs}

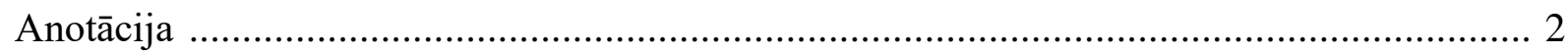

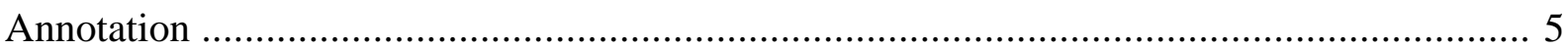

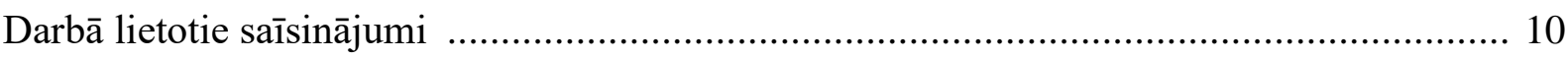

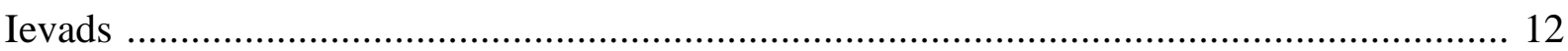

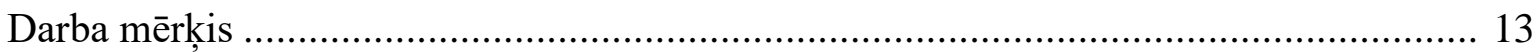

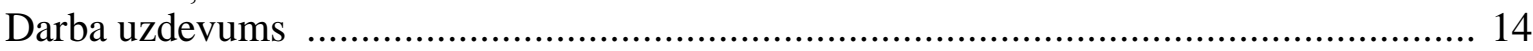

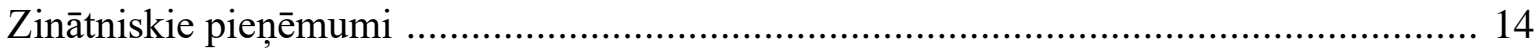

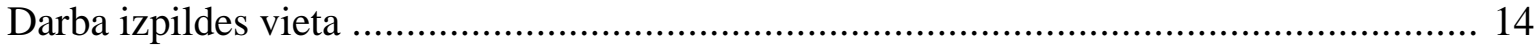

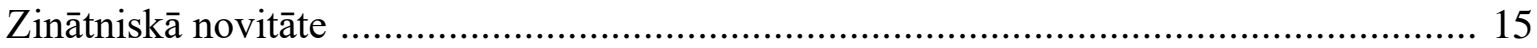

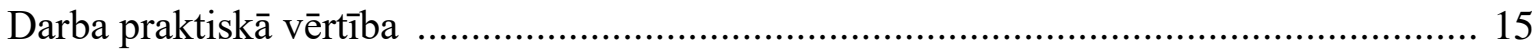

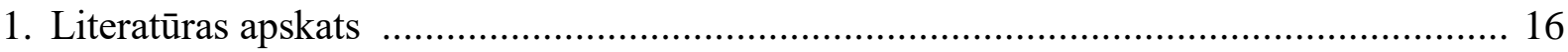

1.1. Spieķkaula distālā gala lūzuma anatomija un morfoloǵija ................................. 16

1.2. Ar spieķkaula distālā gala lūzumiem saistìtā DRUJ nestabilitāte .......................... 24

1.3. Apakšdelma kaulu distālo galu lūzumu klasfikācija ......................................... 26

1.4. Spieḳkaula distālā gala lūzumu ārstēšana ar ĀFA .............................................. 27

1.5. Spieḳkaula distālā gala lūzumu ārstēšana ar VLP .......................................... 28

1.6. Artroskopiski asistēta spieķkaula distālo artikulāro lūzumu ārstēšana ................... 30

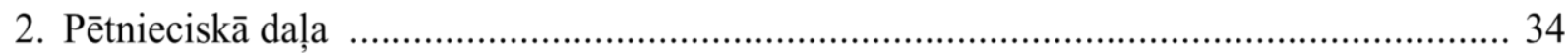

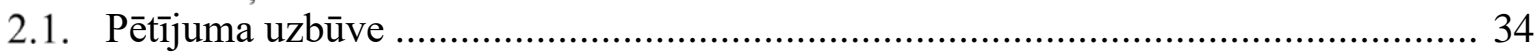

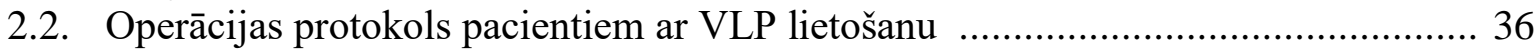

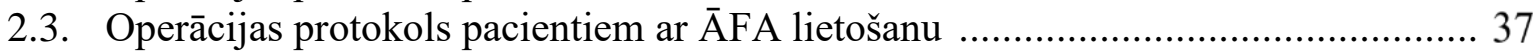

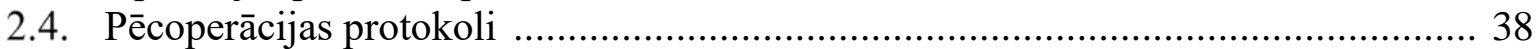

2.5. Primāro datu iegūšanas metodes un sekundāro datu avoti .................................... 39

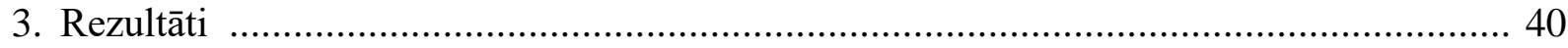

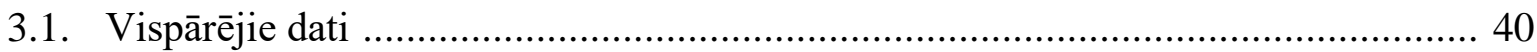

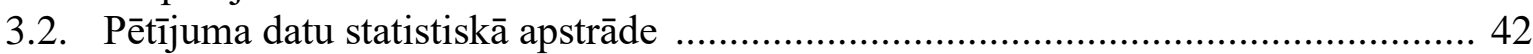

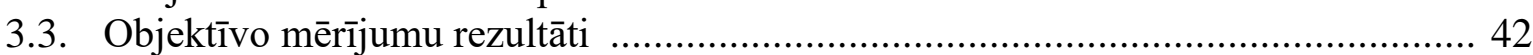

3.3.1. Plaukstas fleksija .................................................................... 42

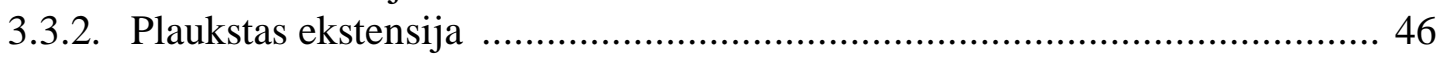

3.3.3. Plaukstas radiālā deviācija ............................................................... 50

3.3.4. Plaukstas ulnārā deviācija ............................................................. 55

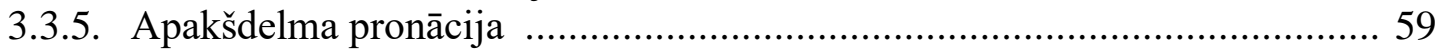

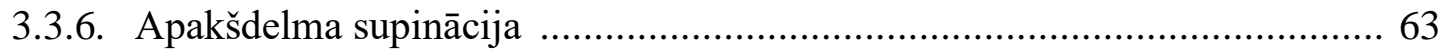

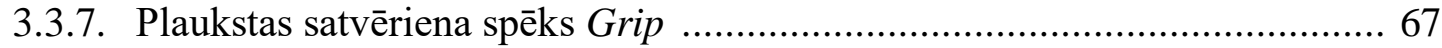

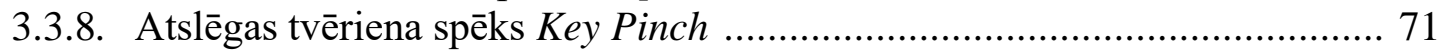

3.3.9. Trīs pirkstu tvēriena spēks Tripod Pinch ............................................... 75

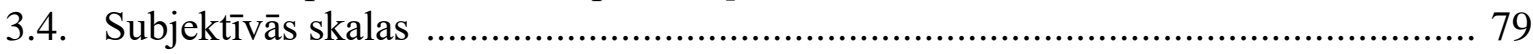

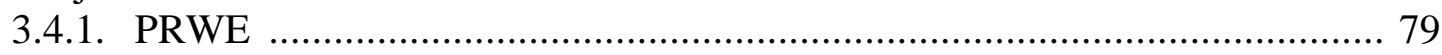

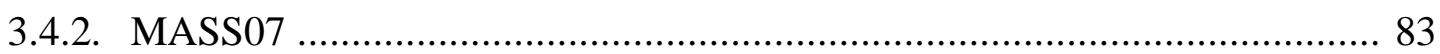

3.4.3. Gartland and Werley modificētā skala .............................................. 87

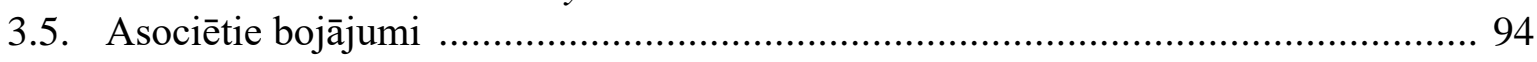

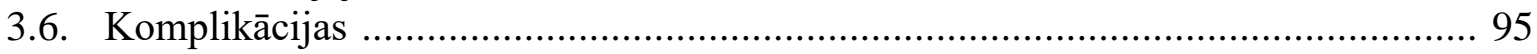

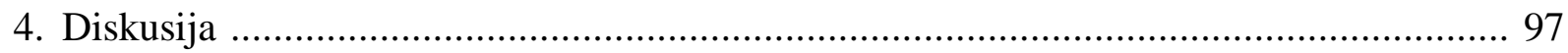

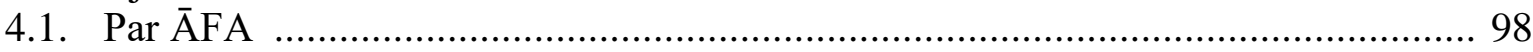

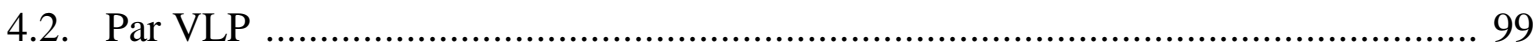

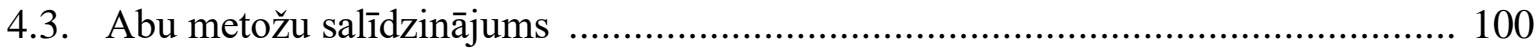


4.4. Artroskopija un distāli artikulāri spieķkaula lūzumi ....................................... 103

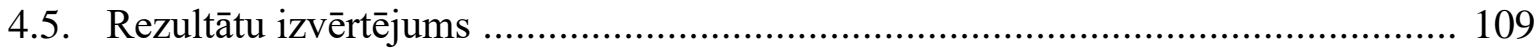

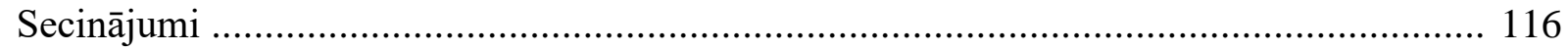

Publikācijas un ziņojumi par promocijas darba tēmu .................................................. 118

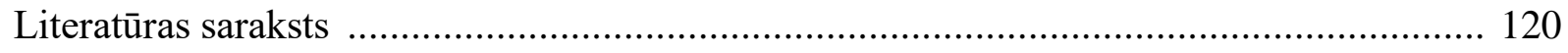

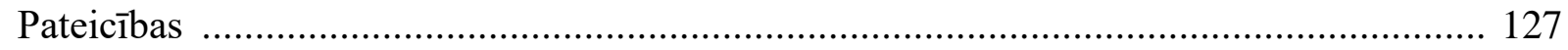

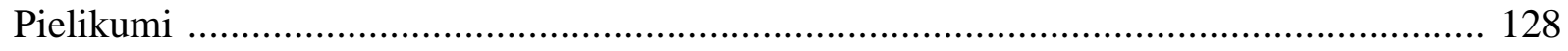

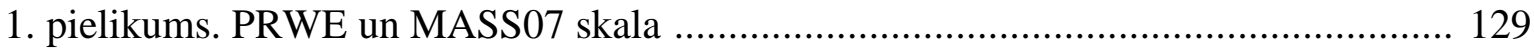

2. pielikums. Modificēta Gartland \& Werley skala ................................................. 131

3. pielikums. Piekrišana pētījumam ...................................................................... 133

4. pielikums. Pētījuma pēcoperācijas protokoli ....................................................... 135

5. pielikums. Ėtikas komitejas atzinums ................................................................. 136

6. pielikums. RAKUS piekrišana akadēmiskā pētījuma veikšanai .............................. 137

7. pielikums. Konfidencialitātes apliecinājums ........................................................ 138

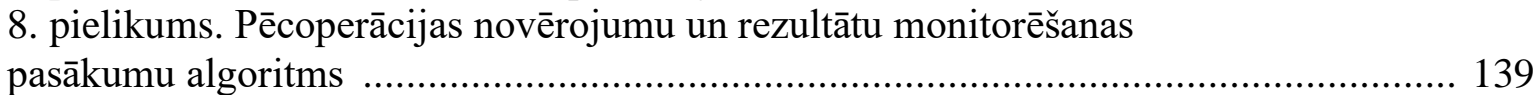

9. pielikums. Algoritms artikulāro spieḳkaula distālo galu lūzumu ārstēšanas

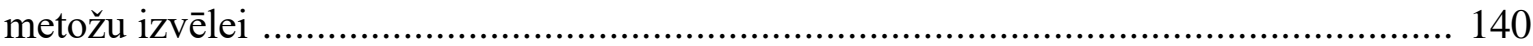

10. pielikums. RTG izmeklējuma veikšanas rekomendācijas .................................... 141

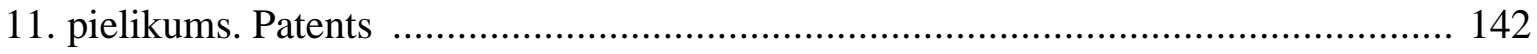




\section{Darbā lietotie saīsinājumi}

AO Arbeitsgemeinschaft für Osteosynthesefragen (zinātniska organizācija)

APL m. abductor pollicis longus

ĀFA ārējās fiksācijas aparāts

CRPS Complex Regional Pain Syndrome - kompleksais regionālo sāpju sindroms

DDRU dorsālais distālās radioulnārās locītavas portāls

DIC dorsal intercarpal ligament - dorsālā interkarpālā saite

DOA deformējoša osteoartroze

DRCL dorsal radio-carpal ligament - dorsālā radiokarpālā saite

DRT dorsal radio-triquetral ligament - dorsālā radiotrikvetrālā saite

DRUJ distal radio-ulnar joint - distālā radioulnārā locītava

ECRB m. extensor carpi radialis

ECRL m. extensor carpi radialis longus

ECU m. extensor carpi ulnaris

EDC m. extensor digitorum communis

EDM m. extensor digiti minimi

EPL m. extensor pollicis longus

FCR m. flexor carpi radialis

LRL Iong radio-lunate ligament - garā radioulnārā saite

LTIL luno-triquetral interosseus ligament - lunotrikvetrālā interosālā saite

MASS07 Modern Activity Subjective Survey of 2007

MCR midkarpālais radiālais portāls

MCU midkarpālais ulnārais portāls

MKK metakarpālais kauls

MKNA minimālā klīniski nozīmīgā atšķirība

MRI magnētiskās rezonanses izmeklējums

N ņūtons (mērvienība)

PDRU proksimālais distālās radioulnārās locītavas portāls

PRUJ proximal radio-ulnar joint - proksimālā radioulnārā locītava

PRWE Patient Related Wrist Evaluation

PQ $\quad m$. pronator quadratus

RAKUS Rīgas Austrumu klīniskā universitātes slimnīca

ROM range of motion - kustību apjoms

RSC radio-scapho-capitate ligament - radioskafokapitētā saite 
RSL radio-scapho-lunate ligament - radioskafolunētā saite

RTG rentgenogrāfija

RVP radiālais volārais portāls

SLAC scapho-lunate advanced collapse - skafolunētais pieaugošais kolapss

SLIL Scapho-lunate interosseus ligament - skafolunētā interosālā saite

STT scaphotrapezium-trapezoideum (portāls un locītava)

TFCC triangular fibrocartilage complex - trīsstūrveida fibrozā skrimšla komplekss

UVP ulnārais volārais portāls

VLP volar locking plate - volārā bloḳējošā plāksne 


\section{Ievads}

Spieķkaula distālo galu lūzumi ir visbiežākā slimnīcu uzņemšanas nodaḷās un traumpunktos reǵistrētā skeleta trauma. Tās incidence no visiem lūzumiem ir 20-30 \% (Ilyas and Jupiter, 2007; MacIntyre and Dewan, 2016). Šiem lūzumiem ir bimodāla izplatība gan vecuma, gan dzimuma izpratnē - sarežğîtus artikulārus lūzumus, kas gūti augstas enerǵijas traumu rezultātā, biežāk sastop gados jaunākiem vīriešiem, taču gados vecākām sievietēm, lai arī sarežğîto lūzumu skaitliski ir mazāk, spieķkaula distālo galu traumas tiek konstatētas daudz biežāk, nekā gados vecākiem vīriešiem (Court-Brown and Caesar, 2006). Pēc publicētajiem medicīniskās statistikas datiem, spieḳkaula distālā gala visu veidu lūzumu sastopamība uz 10000 iedz̄ivotājiem dažādās valstīs ir ar konkrētu tendenci - sievietes dažādu iemeslu dēḷ gūst traumas biežāk, piemēram, sieviešu un vīriešu attiecība Austrālijā 17 : 4 (Sanders et al., 1999), Dienvidkorejā 66,1 : 16,4 (Park et al., 2011), Holandē 45,8 : 10 (de Putter et al., 2013), Kanādā 49 : 14 (Jaglal et al., 2005), Lielbritānijā 36,8 : 9 (O'Neill et al., 2001), Norvēgeijā 75,1 : 18,9 (Diamantopoulos et al., 2012), Šveicē 63,2 : 17 (Lippuner, 2009). Kopumā risks dzīves laikā iegūt spieḳkaula distālā gala traumatisku bojājumu ir $15 \%$ sieviešu un līdz 2 \% vīriešu (Ruch and Papadonikolakis, 2006).

Latvijā šāda veida statistiskie pētījumi līdz šim nav veikti. Pieņemot, ka spieķkaula distālā gala lūzumu incidence ir $20 \%$ no visiem lūzumiem, kas tiek ārstēti medicīnas iestādēs, tad, aptuveni aprēķinot pēc Slimību profilakses un kontroles centra pieejamiem statistikas datiem par 2017. gadu, ņemot vērā pasaulē aprēḳināto procentuālo tendenci, ka AO - C3 lūzumi ir apmēram $32 \%$, Latvijā teorētiski varētu būt apmēram 265 pacienti ar AO - C3 lūzumu gadā.

Pēdējā desmitgadē strauji pieaug spieḳkaula distālā gala sarežğìto, ķirurǵiski ārstējamo lūzumu skaits, ko varētu izskaidrot ar populācijas novecošanos un osteoporozes izraisītajām kaula deǵeneratīvajām izmaiņām, kā arī gados jaunu cilvēku augošo sportisko un arī ekstrēmo vaḷasprieku aktivitāti, kas nereti noved pie augstas enerǵijas traumām (Shukla et al., 2014). Mūsdienās artikulāro lūzumu proporcija no visiem spieḳkaula distālā gala lūzumiem ir no $32 \%$ (Koo et al., 2013) līdz 43,3 \% (Sander et al., 2018). Lūzumu ķirurǵiskās ārstēšanas aktivitāte nenoliedzami ir palielinājusies arī ārstēšanas tehnisko iespēju un implantu evolūcijas ietekmē.

AO (Arbeitsgemeinschaft für Osteosynthesefragen) sistēmā, pēc kuras pienemts klasificēt lūzumus, lai izvēelētos ārstēšanas metodi, un kura kopš 1998. gada ir ieviesta arī Latvijāa, vairākkārt ir notikušas ārstēšanas kritēriju izvērtēšanas (Walenkamp et al., 2015) un standartu maiṇas. Šobrīd spieķa kaula distālā gala lūzumu ārstēšanā tiek lietotas 3 līdz 4 fiksācijas metodes ar nelielām variācijām - stieples un ārējās fiksācijas aparāts (ĀFA), mikronaglas, volārās kompresijas plāksnes, dorsālās plāksnes. Volārās bloḳējošās plāksnes 
(VLP) un stiepḷu + ĀFA izmantošana jau vairākus gadus ir plaši lietota Mikroķirurğijas centrā. Šīs abas metodes ir diametrāli pretējas tehniskajā izpildījumā (operācijas pieeja, mīksto audu papildu traumatizācija u. c.), kā arī atšḳirīgs ir pēcoperācijas rehabilitācijas protokols. Neṇemot vērā daudzos salīdzinošos pētījumus par abu metožu lietošanu un to rezultātiem, kā arī pierādījumus, ka artroskopiski asistētās operācijās plaukstas locītavas virsmu atjaunošana ir iespējama kvalitatīvāk un precīzāk, līdz šim nav veikti abu diametrāli pretējo kirurǵiskās ārstēšanas metožu salīdzinājumi artroskopiski asistētu operāciju grupām. Pētījuma veikšanu motivēja H. J. Kredera atziņa: "Nevis fiksācijas veids un arī ne implants nosaka ārstēšanas iznākumu, bet gan ķirurga spējas panākt apmierinošu kaula repozīciju, saudzējot asinsriti un veicot iespējami mazāk invazīvo ārstēšanas procedūru."

Pêtījuma gaitā, veicot daudzās operācijas, tika attīstīta un uzlabota ķirurğiskā tehnika, samazinot operācijas laiku, kā arī gūtas atziṇas par vienas vai otras ķirurğiskās metodes priekšrocībām atkarībā no lūzumu veida un konfigurācijas. Pētījuma gaitā tika konstatēti arī daudzi mīksto audu asociētie bojājumi un veikta to novēršana, kura bez artroskopiski asistētām operācijām tehniski nebūtu iespējama. Pēcoperācijas periodā pacientu datu savākšanai tika lietotas PRWE (Patient Related Wrist Evaluation), MASSH07 (Modern Activity Subjective Survey of 2007) un Gartland \& Werley skalas, kuras ir pielāgotas interpretācijai un tiek lietotas starptautiskajā literatūrā (Alexander et al., 2008; Changulani et al., 2008; MacDermid et al., 2003). Operācijas gaitas, pēcoperācijas novērošanas, kā arī vēlīno subjektīvo un objektīvo rezultātu izvērtējums ḷauj pamatoti izmantot abas spieḳkaula distālo artikulāro lūzumu artroskopiski asistētās metodes, izvērtējot to tehniskās lietošanas iespējas, materiāli tehnisko bāzi, kā arī ķirurga zināšanas un sagatavotību konkrēto manipulāciju veikšanai.

\section{Darba mērḳis}

Salīdzināt divas artroskopiski kontrolētas spieķa kaula distālās metaepifĩzes multifragmentāru intraartikulāru lūzumu osteosintēzes metodes pēc to agrīnajiem un vēlīnajiem klīniskajiem, radiolog̣iskajiem un funkcionālajiem rezultātiem, operācijas laika un iespējamām komplikācijām. Izstrādāt vienas vai otras metodes lietošanas indikācijas konkrēta lūzuma gadījumā, noteiktai pacientu grupai, prognozējot iespējamo ārstēšanas rezultātu un nākotnē mazinot iespējamo komplikāciju risku. 


\section{Darba uzdevumi}

1. Veikt randomizēto pacientu grupu pēcoperācijas radioloǵisko un funkcionālo rezultātu izvērtēšanu, balstoties uz pacientu dzīves kvalitātes un veselības stāvokḷa izvērtējumu (Gartland and Werley, PRWE un MASS07 skalas), kā arī veiktajām Rtg kontrolēm 1, 3, 6 un 12 mēnešus pēc operācijas.

2. Veikt randomizēto pacientu grupu pēcoperācijas komplikāciju monitorēšanu un iegūto datu analīzi.

3. Noskaidrot ķirurǵiskās ārstēšanas artroskopiskā etapa lietošanas lietderību spieķkaula distālā gala artikulāro lūzumu ārstēšanā.

4. Radīt algoritmu spieḳkaula distālā gala artikulāro lūzumu ārstēšanas metožu lietošanas izvēlei jebkurā traumatolog̣ijas un ortopēdijas stacionārā Latvijā.

5. Radīt sistematizētu pacientu pēcoperācijas novērojumu protokolu pēc spieḳkaula distālo galu lūzumiem, kuru varētu lietot turpmākiem akadēmiskiem pētījumiem Latvijā.

\section{Zinātniskie pieṇēmumi}

Vaḷēja osteosintēze ar plāksni un skrūvēm tiek rekomendēta gados jaunākiem pacientiem ar labāku kaulu struktūru, aktīvu dzīvesveidu un prognozējami garāku dzīvildzi, savukārt saudzējošāka osteosintēze ar stieplēm, papildus veicot distrakciju locītavai ar ārējās fiksācijas aparātu - gados vecākiem cilvēkiem, kuriem kaulu struktūra ir vājāka, potenciāli ir iespējama implantu migrācija, kā arī dzīves aktivitāte ir zemāka. Tiek uzskatīts, ka artroskopiski asistētā artikulāro lūzumu ķirurǵiskā ārstēšana jebkurā lokalizācijā nodrošina precīzāku artikulāro fragmentu repozīciju, kā arī nerada papildus mīksto audu bojājumus, kuri rodas, veicot locītavas virsmu vizualizāciju ar konvencionālām metodēm.

Iespējams, ka jebkura vecuma pacientiem artroskopiski asistēta, mazāk invazīva osteosintēzes metode var radīt labākus apstākḷus pacienta dzīves kvalitātes un plaukstas locītavas funkcionalitātes atjaunošanai, nekā val̨ēja osteosintēze un fiksācija ar plāksni, jo papildus netiek veikta ķirurğiska mīksto audu traumatizācija.

\section{Darba izpildes vieta}

Rīgas Stradiṇa universitāte, SIA "Rīgas Austrumu klīniskā universitātes slimnīca”, stacionārs “Gaiḷezers”, Rokas un plastiskās ḳirurğijas nodaḷa. 


\section{Zinātniskā novitāte}

Pirmo reizi veikts pētījums ar sistematizētu pacientu monitorēšanu, objektīvo un subjektīvo datu pierakstu (Gartland and Werley, PRWE un MASS07 skalas) un iegūto analīzi pēc artroskopiski asistētas spieķkaula distālā gala artikulāro lūzumu ķirurǵiskas ārstēšanas. Tika salīdzinātas divas tehniski piln̄̄gi atšķkirīgas ārstēšanas metodes - miniinvazīva artroskopiski asistēta operācija, lietojot stieples un ĀFA, kā arī standarta vaḷēja osteosintēze ar volāro bloḳēto plāksni, vizualizējot locītavas virsmu optiskā palielinājumā artroskopiski.

Izmantoto pacientu monitorēšanas un novērtēšanas sistēmu plānots rekomendēt plašākai lietošanai, lai, iegūstot lielu datu apjomu, to varētu izmantot ne tikai zinātnisku publikāciju vajadzībām, bet, iespējams, arī statistisko un ekonomisko aprēḳinu veikšanai.

\section{Darba praktiskā vērtība}

1. Izstrādāts patents prototips nepieciešamam instrumentam (ierīce stieples precīza virziena un dziḷuma noteikšanai tās fiksācijai artroskopiski asistētu artikulāru spieķkaula lūzumu osteosintēzei), ar kuru varētu atvieglot artikulāro fragmentu repozīciju un fiksāciju artroskopijas laikā. Iesniegts patenta apstiprināšanai (sk. 11. pielikumu).

2. Pierādīta artroskopiskā etapa nepieciešamība spieḳkaula distālo galu artikulāro lūzumu fragmentu precīzai repozīcijai un asociēto mīksto audu bojājumu diagnosticēšanai, kā arī novēršanai.

3. Radīts praktiskais algoritms spieḳkaula distālo galu artikulāro lūzumu ārstēšanai, kurš lietojams jebkurā traumatolog̣ijas un ortopēdijas nodaḷā vai stacionārā.

4. Ieviests pacientu pēcoperācijas novērošanas, kā arī subjektīvo un objektīvo datu reǵistrācijas algoritms, kurš lietojams jebkurā traumatoloǵijas un ortopēdijas nodaḷā vai stacionārā. 


\section{Literatūras apskats}

\subsection{Spieḳkaula distālā gala lūzuma anatomija un morfoloğija}

Labāk izprotot spieķkaula distālā gala anatomiju - ne tikai kaulu uzbūvi un struktūru, bet arī locītavas saišu lokalizācijas nozīmi lūzuma fragmentu veidošanā, to savstarpējo mijiedarbību ar karpālajiem kauliem un interkarpālajām locītavām, kā arī citām stabilizējošām struktūrām -, mums tiek sniegta iespēja precīzāk novērst traumas radītos bojājumus un radīit labākus priekšnoteikumus pacientu veselības un dzīves kvalitātes uzlabošanā.

Plaukstas locītavas anatomiskā uzbūve ir ḷoti sarežğìta, tāpat kā tās veicamās funkcijas. Anatomiski to veido spieḳkaula (radius) distālais gals, elkoṇkaula (ulna) distālais gals, kas savstarpēji veido distālo radioulnāro locītavu (DRUJ - distal radio-ulnar joint), kā arī plaukstpamata (carpus) kaulu proksimālā rinda - laivveida kauls (os scaphoideum), mēness kauls (os lunatum), trīsstūrveida kauls (os triquetrum), zirṇveida kauls (os pisiforme). Funkcionāli plaukstas locītavas kustību nodrošināšanā tiek iesaistîta arī karpālo kaulu distālā rinda - trapeckauls (os trapezium), trapecveida kauls (os trapezoideum), galvinkauls (os capitatum) un kāškauls (os hamatum). Plaukstas locītavas kustības notiek trijās plaknēs: saliekšana (flexio) - atliekšana (extensio); radiāla (RA) un ulnāra (UA) deviācija (abductio); pronācija un supinācija (pronatio / supinatio), kā arī visu šo kustību kombinācijas visdažādākajās kustību amplitūdās.

Spieķkaula distālā gala anatomiskajā uzbūvē ir vairākas specifiskas īpatnības, kuras obligāti jānnem vērā, uzsākot lūzumu ārstēšanu. Locītavas virsmai ir trīsstūrveidīga forma ar trīsstūra virsotni processus styloideus radii galā. Locītavas virsma veido izliekumu volārā un ulnārā virzienā. Normālās anatomijas raksturošanai izmanto sekojošus spieķkaula parametrus: radiālā inklinācija $23^{\circ}$ (robežas $13-30^{\circ}$ ), volārā pārkare $12^{\circ}$ (robežas $1-21^{\circ}$ ), spieķkaula augstums $12 \mathrm{~mm}$ (robežas $8-18 \mathrm{~mm}$ ).
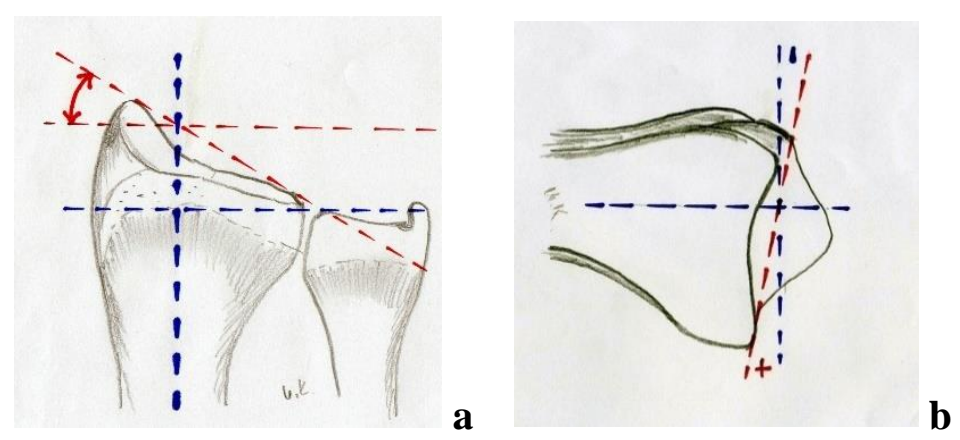

$\mathbf{a}$

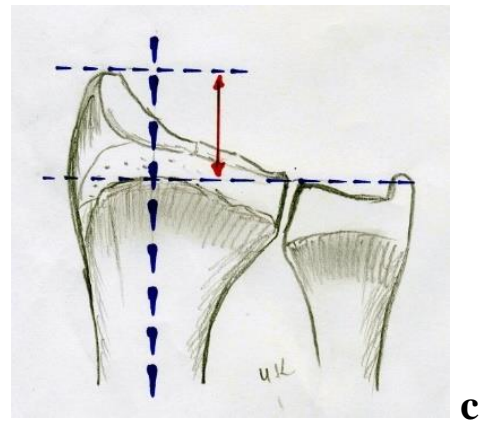

1.1. attēls. Spieḳkaula distālā gala anatomiskie parametri - radiālā inklinācija (a), volārā pārkare (b), spieḳkaula augstums (c) (autora zīmējumi) 
Spieķkaula distālā gala mikrostruktūra atgādina arkveida tilta uzbūvi ar sekojošām līdzībām: subhondrālā kaula plātne - tilta klājums, savienojošās trabekulas - balsti, trabekulārās arkas - multiplas gotiskās velves, spiek̦kaula diafīze - pamatne (Bain et al., 2017) (sk. 1.2. attēlu).

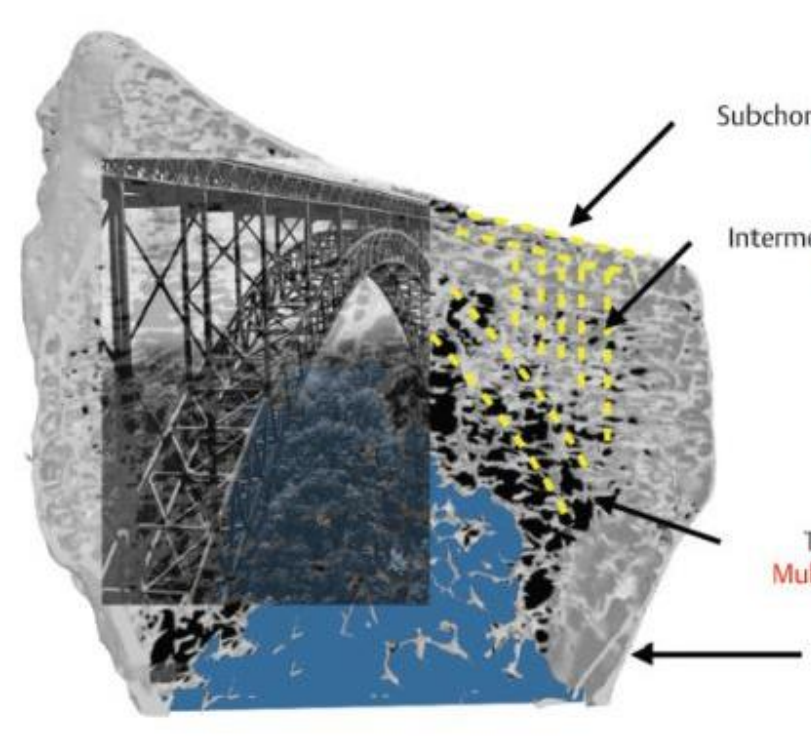

Coronal

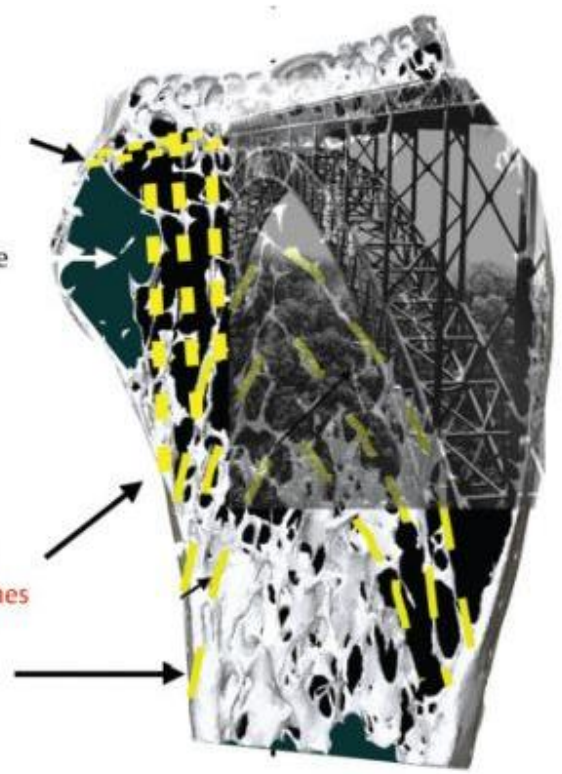

Sagittal

1.2. attēls. Spieḳkaula distālā gala mikrostruktūra (Copyright @ Gregory Bain, MD)

Šī uzbūve pārvada un sadala kompresējošos spēkus no locītavas virsmas uz kaula diafīzi. Kustībā esošas plaukstas radītos spēkus artikulārā lūzuma gadījumā sadala trijās kolonnās, kuras savā starpā satur vairāki saišu gredzeni, kuru pamatuzdevums ir radīt stabilitāti starp karpālo kaulu proksimālo un distālo rindu.

Mandziak ar kolēgiem ir izpētījuši, ka zemas enerǵijas artikulāro lūzumu gadījumos lūzumu līnijas gandrīz vienmēr atrodas starp plaukstas locītavas saišu insercijas zonām, savukārt augstas enerğijas traumas gadījumos locītavas virsmas bojājumu veidi ir dažādi, atkarīgi no lūzuma brīdī izmantoto spēku virzieniem un jaudas (Mandziak et al., 2011). 


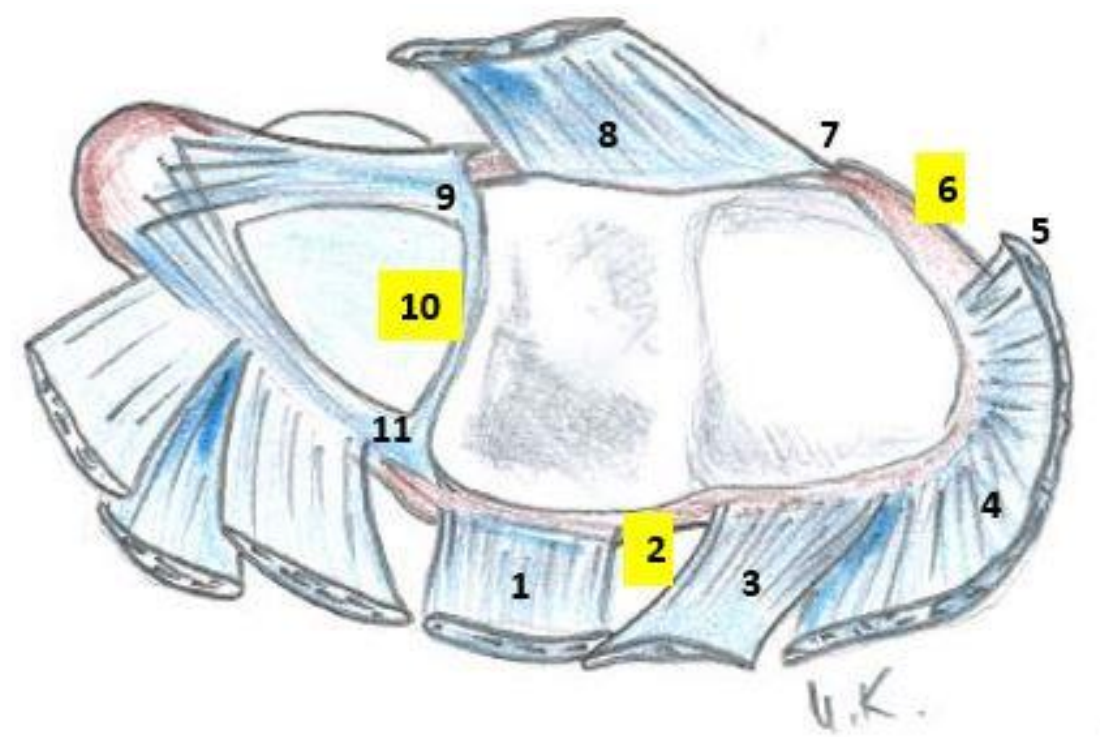

1.3. attēls. Radiokarpālās $(\boldsymbol{R C})$ locītavas saišu un biežāko artikulāro lūzumu rašanās vietu savstarpējais izvietojums (autora zīmējums - reprodukcija no M. Crespi zīmējuma Anatomy of the fracture, Distal Radius Fractures and Carpal Instabilities: FESSH IFSSH 2019 Instructional Book. del Piñal F, ed. 1st Edition. Thieme; 2019)

1-SRL - short radiolunate lig.; 2-RSL - radioscapholunate lig.; 3- LRL - long radiolunate lig.; 4- RSC - radioscaphocapitate lig.; 5-6-7 - zona starp RSC un DRC; 8- DRC - dorsal radiocarpal lig.; 9-DRU - dorsal radioulnar lig.; 10 - sigmoīdās ieloces (sigmoid notch) centrālā daḷa; 11-PRU - palmar radioulnar lig.; 2; 6; 10 - biežākās lūzumu rašanās zonas.

Biomehāniski saites nodrošina stabilitāti un spēj pretoties stiepes spēkam / iestiepumam, kurš sasniedz maksimumu jebkuras kustības galējā punktā. Kauls savukārt neitralizē / pretdarbojas kompresējošo spēku radītajam spiedienam, bet nav izturīgs iestiepumā. Atklājums, ka saišu stiprinājuma zonas parasti paliek neskartas, izskaidro un apstiprina faktu, ka, veicot locītavas iestiepšanu (ligamentotaksi), pat komplicētu artikulāro lūzumu gadījumā ir iespējama gandrīz anatomiska lūzuma fragmentu repozīcija un kaula konsolidācijas sagaidīšana, fiksējot ar ĀFA.

Ir pierādīta sakarība starp karpālo kaulu pozīciju traumas brīdī un tās mehānisma radīto spieḳkaula distālā gala virsmas bojājuma veidu - radiālā deviācijā esoša plauksta rada sākotnējo triecienu caur os capitatum ar os scaphoideum pret laivveidkaula faseti (scafoid facet), ulnārā deviācijā esoša plauksta - triecienu ar os lunatum pa mēnesskaula faseti (lunate facet), savukārt neitrālā pozīcijā esoša plauksta rada vienlaicīgu triecienu ar abiem iepriekšminētajiem kauliem pa spieķkaula virsmu (Bain et al., 2013) (sk. 1.4. un 1.5. attēlu). 

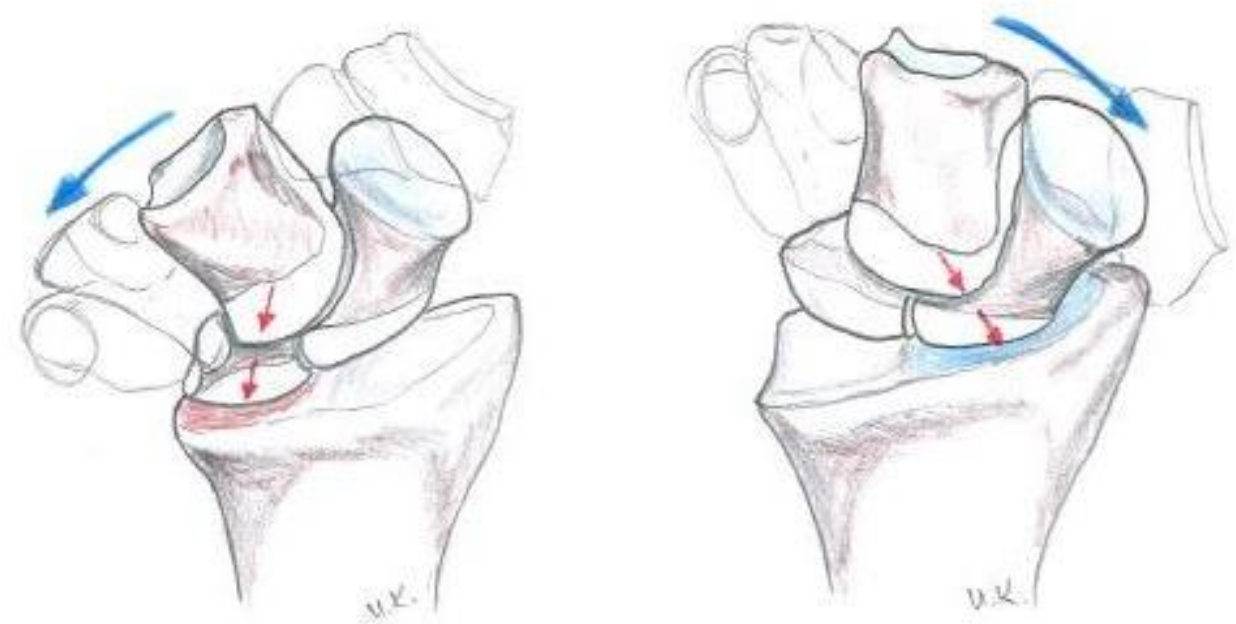

1.4. attēls. Ulnārā un radiālā deviācijā esošas plaukstas ietekme uz spieḳkaulu lūzuma brīdī (autora zīmējums, reprodukcija no M. Crespi zīmējuma Anatomy of the fracture,

Distal Radius Fractures and Carpal Instabilities: FESSH IFSSH 2019

Instructional Book. del Piñal F, ed. 1st Edition. Thieme; 2019)
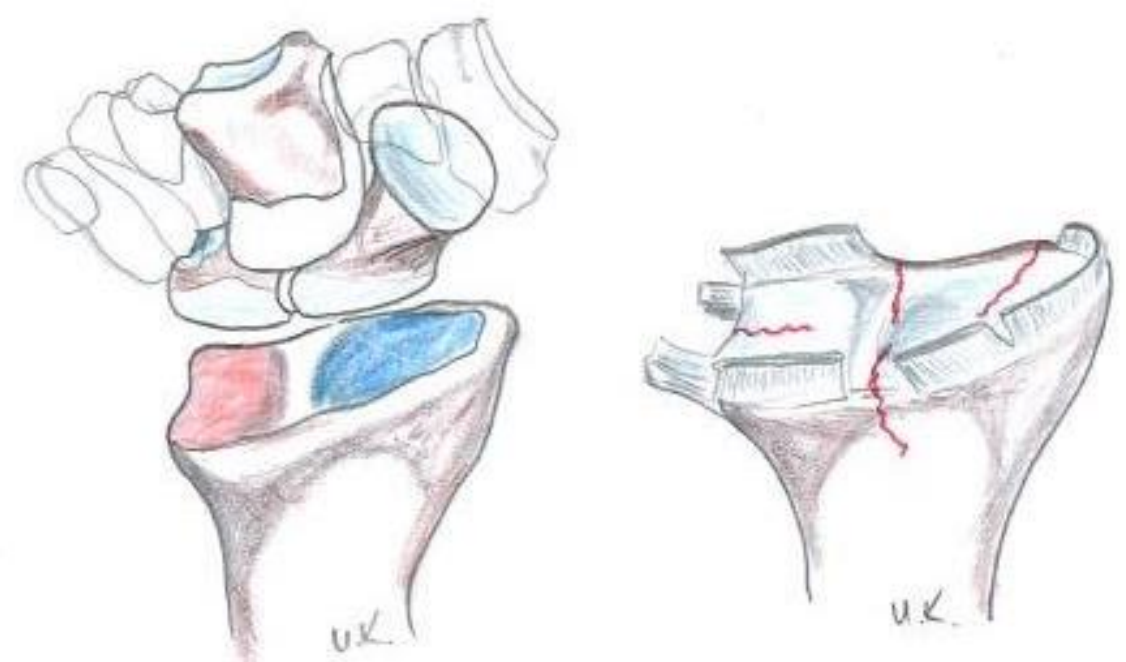

1.5. attēls. Neitrālā pozīijāà esošas plaukstas ietekme uz spieḳkaulu lūzuma brīdī un biežākās artikulāro lūzumu rašanās vietas (autora zīmējums, reprodukcija no M. Crespi zīmējuma Anatomy of the fracture, Distal Radius Fractures and Carpal Instabilities: FESSH IFSSH 2019 Instructional Book. del Piñal F, ed. 1st Edition. Thieme; 2019)

Šo traumas mehānismu laikā tiek bojātas ne tikai kaula virsmas, bet arī interkarpālās saites un citas plaukstas locītavu stabilizējošās struktūras - SLIL, LTIL, TFCC. Visbiežāk bojāta tiek Skafo-lunātā interkarpālā saite (Scapholunate interosseus ligament - SLIL), jo tā atrodas lūzumu radošo spēku epicentrā (sk. 1.6. attēlu). SLIL bojājumi pēc Geissler artroskopiskās klasifikācijas tiek iedalīti 4 pakāpēs (sk. 1.1. tabulu). 

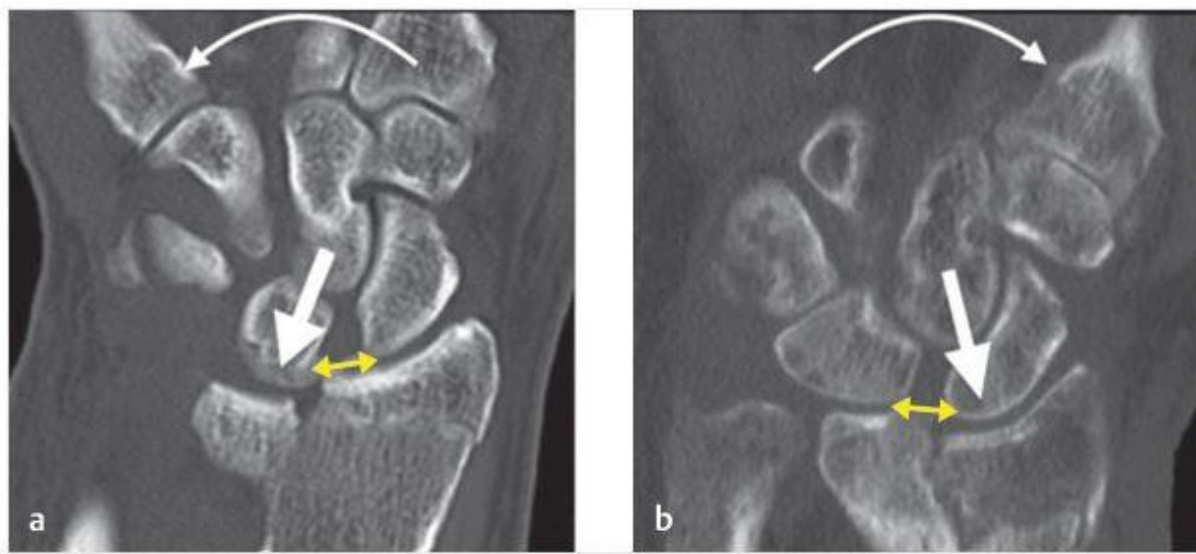

1.6. attēls. SLIL bojājumi ulnāri (a) vai radiāli (b) deviētas plaukstas pozīcijā

(Copyright (C) Gregory Bain, MD)

1.1.tabula

Geissler un kolēǵu ieteiktā SLIL artroskopiskā bojājumu klasifikācija

\begin{tabular}{|c|l|l|l|}
\hline Pakāpe & \multicolumn{1}{|c|}{ RC locītava } & \multicolumn{1}{c|}{ MC nestabilitāte } & \multicolumn{1}{c|}{ Locītavas "kāpe" } \\
\hline $\mathbf{1 .}$ & $\begin{array}{l}\text { SLIL hemorāgija, nav saišu } \\
\text { vājuma }\end{array}$ & Nav & Nav \\
\hline $\mathbf{2 .}$ & $\begin{array}{l}\text { SLIL dal̄ējs plīsums, } \\
\text { izvelvējums, nav saišu vājuma }\end{array}$ & Neliels valị̄gums $(<3 \mathrm{~mm})$ & Tikai midkarpāla \\
\hline $\mathbf{3 .}$ & $\begin{array}{l}\text { Saišu vājums, dal̄ējs plīsums } \\
\text { vai neliels pilna biezuma } \\
\text { plīsums }\end{array}$ & $\begin{array}{l}\text { Artroskopijas zondi var } \\
\text { iestumt starp karpālajiem } \\
\text { kauliem }\end{array}$ & $\begin{array}{l}\text { Midkarpāla un } \\
\text { radiokarpāla }\end{array}$ \\
\hline $\mathbf{4 .}$ & Pilns bojājums & $\begin{array}{l}\text { Izteikta nestabilitāte, 2,7 mm } \\
\text { skopu var izstumt cauri } \\
\text { locītavai (drive-through sign })\end{array}$ & $\begin{array}{l}\text { Midkarpāla un } \\
\text { radiokarpāla }\end{array}$ \\
\hline
\end{tabular}

SLIL dažādas pakāpes bojājumu incidence ir no 18 līdz $95 \%$, luno-trikvetrālās saites (luno-triquetral interosseus ligament - LTIL) bojājumu incidence svārstās no 0 līdz 52 \%, savukārt Triangulārā fibroskrimšla kompleksa (TFCC) bojājumus var konstatēt no 6 līdz 67 \% spieḳkaula distālā gala artikulāro lūzumu pacientiem (Forward et al., 2007; Geissler et al., 1996; Peicha et al., 1999; Roulet et al., 2020). Sistēmiskā literatūras apskatā (12 pētījumi, 467 pacienti, vidējais pacientu novērošanas laiks - 22 mēneši) SLIL bojājumi tiek konstatēti $41 \%$ gadījumu, no kuriem 76,2 \% ir Geissler I-II pakāpes bojājumi (sk. 1.5. attēlu), bet 23,8 \% ir Geissler III-IV pakāpes bojājumi (Kastenberger et al., 2020). Ilgtermiṇā veiktā pacientu novērojumā ir secināts, ka akūtu SLIL bojājumu gadījumos, ja saglabāta plaukstas locītavas ārējo (extrinsic) saišu stabilitāte, notiek sadzīšana bez sekundāru deformāciju veidošanās (Mrkonjic et al., 2015; Swart and Tang, 2017), taču ir sastopama arī diametrāli pretēja informācija - laikus neārstēti SLIL bojājumi izraisa sekundāru interkarpālu nestabilitāti (Forward et al., 2007) un ilgtermin̄ā var novest plaukstu pie SLAC (scapho-lunate advanced collapse) un deformējošas osteoartrozes veidošanās (Lindau, 2017). 


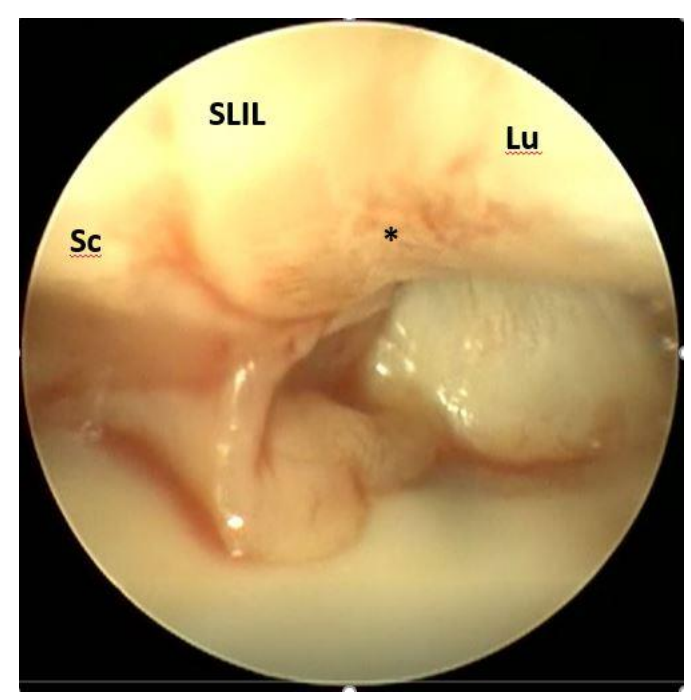

\section{7. attēls. SLIL II pakāpes bojājums ar hemorāgijām (*) un izvelvēšanos (autora foto)}

$\mathrm{Sc}$ - os scaphoideum, Lu - os lunatum (autora foto).

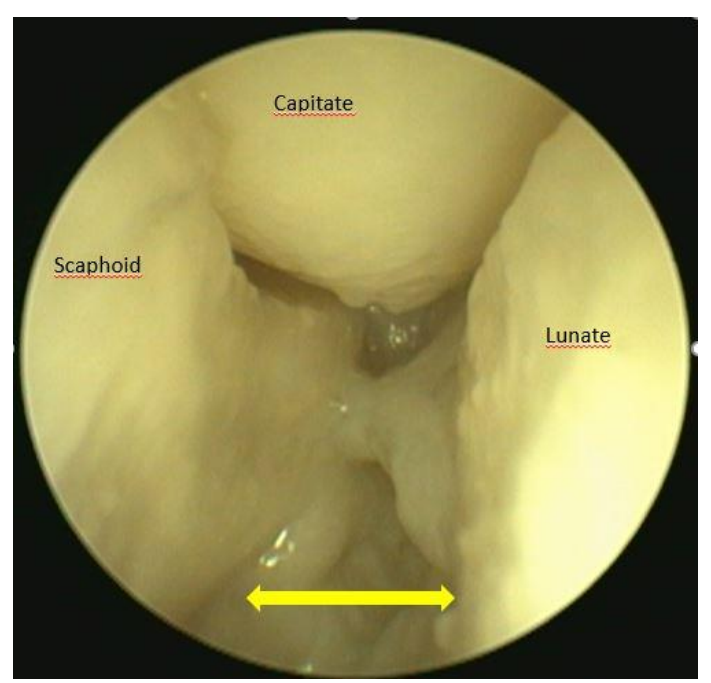

1.8. attēls. SLIL IV pakāpes plīsums

2,7 mm artroskops piln̄̄gi brīvi ieiet starp os scaphoideum un os lunatum, augšā redzams os capitatum. Ar dzelteno bultu apzīmēta sprauga starp kauliem (autora foto).

Distālā radioulnārā locītava (DRUJ-distal radio-ulnar joint), iespējams, ir būtiskākā plaukstas locītavas daḷa, kura ḷauj cilvēkam veikt rotācijas kustības apakšdelmā, saglabājot plaukstas satvēriena funkcijas. Elkoņkauls ir apakšdelma stabilitātes balsts, ap kuru spieķkaulam muskuḷu mijiedarbības rezultātā ir iespējas veikt rotācijas kustības. Šo kustību stabilitāti nodrošina TFCC, ulnokarpālo saišu komplekss, ECU cīpsla un tās maksts, m. pronator qudratus (PQ), interosālā membrāna ar saitēm un paši kauli kopā ar locītavas kapsulu. Apakšdelma pronācija un supinācija vienlaikus notiek gan proksimālajā (PRUJproximal radio-ulnar joint), gan distālajā radioulnārajā locītavā (DRUJ), tāpēc šīs abas locītavas būtu jāuzskata kā vienota apakšdelma locītava (Hagert, 1994). 
TFCC ir galvenais DRUJ stabilizējošais elements (Palmer and Werner, 1984). To veido artikulārais disks, ulnokarpālās saites, distālās radioulnārās saites, kurām izškiir dorsālās un palmārās škiedras, ar sākumu pie spieḳkaula ulnārās puses malām un kopīgu nobeigumu elkonkaula îlenveida izauguma pamatnē - fovea capitis ulnae. Šì kompleksa uzbūve ir loti sarežğìta, un tikai pēdējo 2-3 desmitgažu laikā virknē anatomisko pêtījumu tā morfolog̣ija un biomehānika ir izprasta, vienlaikus sniedzot izpratni arī par iespējamiem TFCC bojājumu veidiem un to ietekmi uz visas plaukstas biomehāniku.

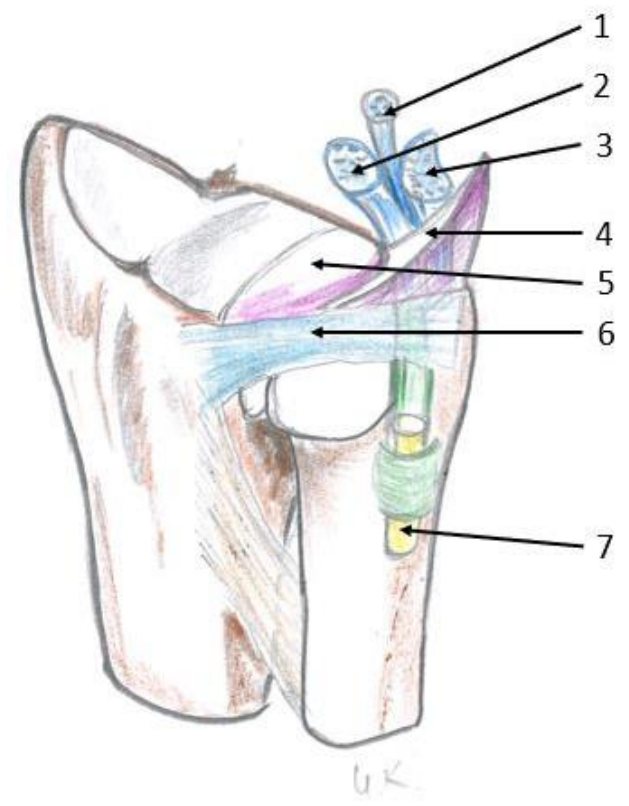

\section{9. attēls. TFCC "seklās" sastāvdaḷas}

1-UCL (ulnocapitate lig.); 2-ULL (ulnolunate lig.); 3-UTL (ulnotriquetral lig.); 4-menisks; 5-ulnokarpālais disks; 6-DRUL (dorsal radio-ulnar lig.); 7-ECU cīpsla (autora zīmējums, reprodukcija no Distal radioulnar joint: functional anatomy, including pathomechanics by J. R. Haugstvedt et al., The Journal of Hand Surgery (European Volume) XXE(X) 1-8). 


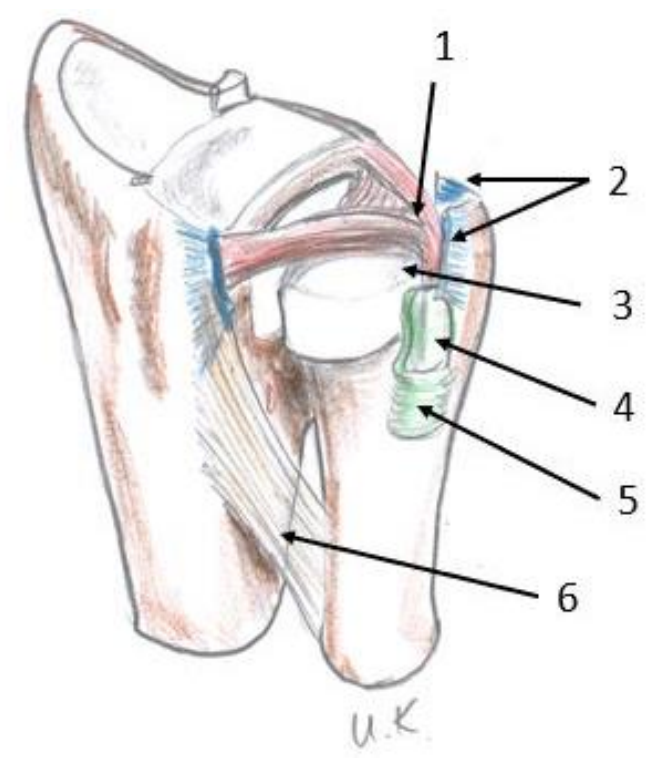

\subsection{0. attēls. TFCC “dziḷās”sastāvdaḷas}

1 - dzilo škiedru stiprinājums elkoṇkaula galviņas bedrē; 2 - DRUL un PRUL stiprināšanās zona;

3 - prestiloīdā zona un fovea capitis ulnae; 4 - periosts un ECU cīpslas maksts; 5 - ECU cīpslas maksts škiiedrainais apvalks (retinaculum); 6 - interosālās membrānas (IOM) distālais slīpais kūlìtis (autora zīmējums, reprodukcija no Distal radioulnar joint: functional anatomy, including pathomechanics by

J. R. Haugstvedt et al., The Journal of Hand Surgery (European Volume) XXE(X) 1-8).

Šobrīd eksistē divi dažādi TFCC biomehāniku izskaidrojošie salīdzinājumi. Nakamura ar līdzautoriem 1996. gadā ieteica TFCC morfologiski sadalīt trijos komponentos - distālā, stabilā daḷa, kura darbojas kā šūpuḷtīkls (hammock concept), pret kuru kustību laikā atbalstās karpālo kaulu proksimālās rindas ulnārā mala, volārā pusē atrodas UTL -ulnotriquetral lig. un proksimālā daḷa, kurā atrodas dziḷās radioulnārās saites (Nakamura et al., 1996). Otru salīdzinājumu ir aprakstījusi Atzei un Luchetti 2011.gadā. Viṇi piedāvā tā saukto Aisberga konceptu, kurā TFCC tiek sadalīts divās dạ̣ās - distālā vai tā sauktā redzamā virsma un proksimālā vai t. s. iegremdētā daḷa (Atzei and Luchetti, 2011). Distālās daḷas komponenti UC saites, menisks kopā ar virspusējām artikulārajām saitēm un ulnokarpālais disks - atbalsta un aptur karpālo kaulu ulnāro daḷu kustības laikā, darbojoties kā trieciena absorbētājs, kā arī ir atbildīgi par slodzes transformēšanu plaukstas ulnārajā pusē. TFCC proksimālais komponents sastāv no dziḷajām šḳiedrām, kuras stiprinās elkoṇkaula galviņas bedrītē un stabilizē gan karpālo kaulu ulnāro daḷu, gan DRUJ. Š̄i "iegremdētā daļa”, izmantojot analogiiju ar aisbergu, ir uzskatāma par lielāko un svarīgāko TFCC daļu. Histoloǵiskajos pētījumos ir konstatēts, ka ulnokarpālais disks un menisks pārsvarā veidots no irdenajiem saistaudiem, norādot uz buferizācijas funkciju, turpretī RU un UL saišu struktūra ir blīva un tās ir domātas DRUJ centrālai stabilizācijai (Nakamura and Yabe, 2000). Gan MRI izmeklējumos, gan anatomiskajos preparātos var izsekot trim TFCC daḷām - proksimālā jeb dziḷā šķiedru daḷa, vidējā ar krusteniskām šḳiedrām, kuras iet no radiopalmārās virsmas uz periostu un ECU maksts pamatni, savukārt otras iet no radiodorsālās virsmas uz elkoņkaula îlenveida izauguma palmāro 
virsmu, kā arī trešā kārta - distālās, virspusējās šķiedras, kuras aptver elkoṇkaula īlenveida izaugumu (sk. 1.11. attēlu) (Haugstvedt et al., 2017).

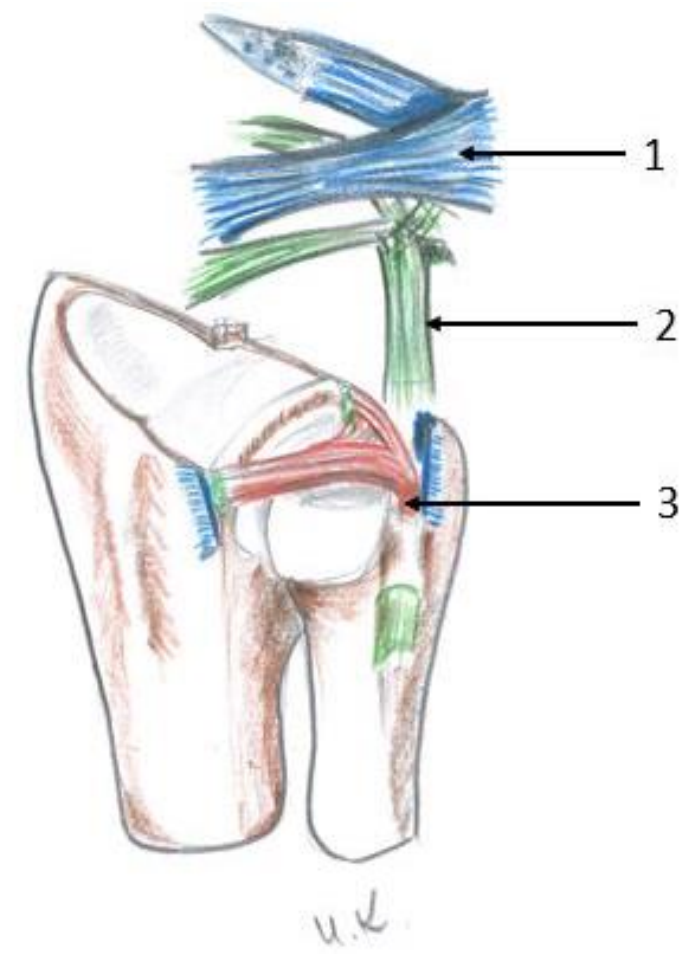

1.11. attēls. TFCC 3 kārtas: 1 - DRUL un PRUL, 2 - krustenisko šḳiedru daḷa, 3 - dziḷo šķiedru sistēma (autora zīmējums, reprodukcija no Distal radioulnar joint: functional anatomy, including pathomechanics by J. R. Haugstvedt et al., The Journal of Hand Surgery (European Volume) XXE(X) 1-8)

\subsection{Ar spieḳkaula distālā gala lūzumiem saistītā DRUJ nestabilitāte}

Biomehāniskajos anatomiskajos pētījumos ir pierādīts, ka spieḳkaula distalās metafīzes saīsināšanās par $3 \mathrm{~mm}, 10^{\circ}$ volāra vai dorsāla leṇksveida nobīde, kā arī $2 \mathrm{~mm}$ radiāla nobīde var radīt DRUJ nestabilitāti (Nishiwaki et al., 2015; Saito et al., 2013). DRUJ jau pēc būtības ir potenciāli nestabila locītava, jo spieķkaula sigmoidās ieloces virsma $(18 \mathrm{~mm})$ ir divas reizes lielāka par elkoṇkaula galviņas izmēriem $(8 \mathrm{~mm})$. Locītavas kapsula un saišu komplekss ir galvenie DRUJ stabilizējošie faktori. Spieķkaula distālā gala lūzumu gadījumos traumas radītie spēki, atdalot spieḳkaulu no elkoṇkaula galviṇas, parasti atrauj TFCC dziḷās šķiedras ar vai bez elkoņkaula īlenveida izauguma lūzuma. TFCC bojājuma smagums korelē ar artikulāro fragmentu veidošanās biežumu un fragmentu dislokācijas pakāpi (Richards et al., 1997). Elkoṇkaula īlenveida izaugumu lūzumus konstatē 55 līdz $65 \%$ gadījumu, no kuriem apmēram 25 \% gadījumu veidojas nesaaugšana - pseidoartroze. Potenciālu DRUJ nestabilitāti var radīt lūzumi, kuri šḳērso īlenveida izauguma pamatni, jo tā ir zona, kurā stiprinās arī TFCC proksimālās šķiedras (Almedghio et al., 2018; Zenke et al., 2009). Spieķkaula sigmoīdās ieloces locītavas virsmas artikulāri lūzumi tiek konstatēti 55 līdz $65 \%$ no visiem artikulārajiem 
spieḳkkaula distālā gala lūzumiem. Parastajās rentgenogrammās, ja fragmentu dislokācija nav būtiska, tos var konstatēt tikai apmēram $35 \%$ gadījumu, tāpēc artikulāro lūzumu pirmsoperācijas izmeklēšanā tiek rekomendēta datortomogrāfija (Rozental et al., 2001). Ja dislocēti sigmoidās ieloces lūzumi tiek atstāti neārstēti, tad DRUJ nestabilitāte un locītavas virsmu neatbilstîba noved pie deformējošas osteoartrozes un sāpīgas, kā arī mazkustīgas plaukstas locītavas (Del Pinal et al., 2012).

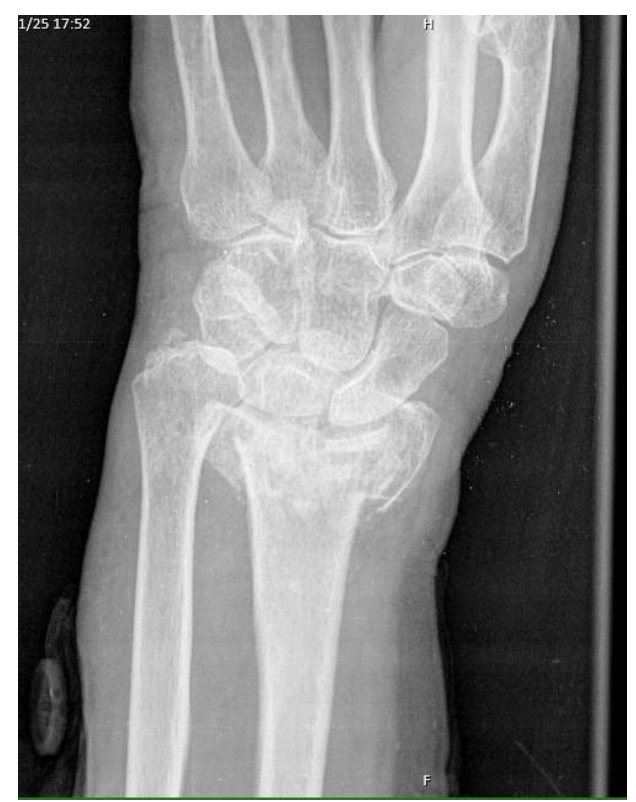

1.12. attēls. Artikulārs, multifragmentārs spieḳkaula distālā gala lūzums ar potenciālu TFCC bojājumu, DRUJ nestabilitāti un sigmoidās virsmas artikulāru lūzumu (autora foto)

Iepriekšminēto papildu bojājumu diagnostikai un potenciālo problēmu risināšanai mūsdienās tiek rekomendēta artroskopiski asistēta spieķkaula distālā gala lūzumu ḳirurǵiskā ārstēšana, kuras laikā jāveic lūzumu virsmu inspekcija, TFCC un citu stabilizējošo struktūru bojājumu diagnostika, kā arī novēršana, radot maksimāli labus apstākḷus pacienta veiksmīgai rehabilitācijai. DRUJ stabilitātes atjaunošanai var lietot gan vaḷējas, piemēram, elkoṇkaula īlenveida izauguma fiksāciju ar stieplēm un savelkošo cilpu, gan artroskopiskas ķirurǵiskās ārstēšanas metodes. 


\subsection{Apakšdelma kaulu distālo galu lūzumu klasfikācija}

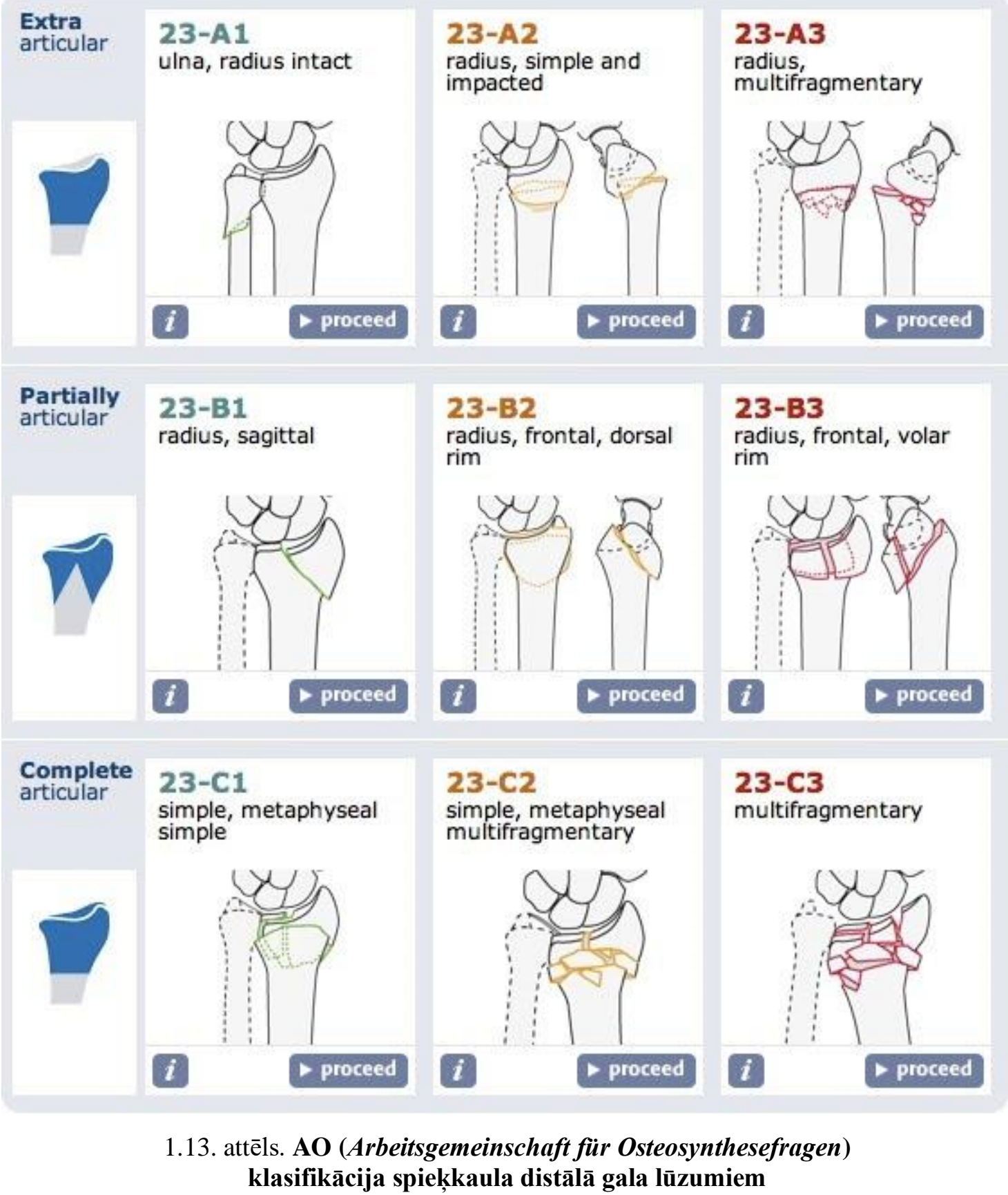

Müller AO klasifikācija spieķkaula distālā gala lūzumiem pirmo reizi tika publicēta 1987. gadā kā daḷa no autoru grupas izstrādātās garo stobrkaulu lūzumu klasifikācijas. Šo klasifikāciju pien̄ēma Ortopēdijas un traumu asociācija (Orthopaedic Trauma Association) un 2007. gadā šo klasifikāciju pārdēvēja par AO / OTA Classification of Fractures and Dislocations. Jau tās sākotnējais dizains tika veidots tā, lai varētu atspoguḷot ievainojuma smaguma pakāpi un lokalizāciju, informētu par plānotās ārstēšanas taktiku un iespējām, potenciālo ārstēšanas iznākumu, kā arī atvieglotu zinātnisko komunikāciju. Š̉ joprojām ir visplašāk izmantotā stobrkaulu lūzumu klasifikācijas metode arī mūsdienās. Oriǵinālajā versijā lūzumi tiek klasificēti trijos veidos (A, B un C), 9 grupās (1, 2 un 3) un 27 apakšgrupās 
(0,1, 0,2 un 0,3). Saīsinātais variants, kurā ietvertas 9 kategorijas (veidi un grupas), ir visplašāk lietotā klasifikācijas forma.

\subsection{Spieḳkaula distālā gala lūzumu ārstēšana ar ĀFA}

Pēdējo 50 gadu laikā ārējās fiksācijas ierīces ir piedzīvojušas neskaitāmas konfigurācijas un modifikācijas, taču metodes principi ir palikuši nemainīgi. Lielākā daḷa ārējās fiksācijas aparātu balstās uz ligamentotaksi (iestiepjot locītavu, saišu aparāts palīdz reponēt lūzuma fragmentus), lai nodrošinātu fragmentu repozīciju un stabilitāti. Ligamentotakse tiek panākta ar trakciju, iestiepjot RSC un LRL saites. Biomehāniski ārējās fiksācijas metode nodrošina relatīvu stabilitāti, salīdzinot ar plākšņu fiksācijas metodi, kura nodrošina daudz lielāku lūzuma stabilitāti. Ārējās fiksācijas ierīcēm, neskatoties uz to, ka tās nav rigidas konstrukcijas, ir jāspēj pretoties līidz $245 \mathrm{~N}$ lielam spēkam - tik liels ir intraartikulārais spiediens plaukstā, tai atrodoties radiālā deviācijā un apakšdelma supinācijā, tāpēc papildu stiepḷu lietošana caur lūzuma fragmentiem palielina ĀFA pretestību un mazina sekundārās dislokācijas iespējas (Dunning et al., 1999; Wolfe et al., 1998). Lai nodrošinātu nepieciešamo pretestību, ķirurgam ir jāievēro pareiza ĀFA stieņu, savienotājmezglu un fiksatoru konfigurācija, kā arī piel̦aujamie izmēri. Klasiska ĀFA aplikācijas tehnika ir Šanca skrūvju implantācija 2. metakarpālā (MKK) kaula dorsoradiālā virsmā un spieķkaula diafìzes dorsoradiālā virsmā proksimāli no lūzuma vietas monolaterāla Hofmaņa tipa aparāta gadījumā vai Kiršnera stiepḷu ievietošana riņķveida aparātu lietošanas gadījumos, izveidojot tiltam līdzīgu veidojumu pār plaukstas locītavu. Tiek uzskatīts, ka ar šādu fiksācijas metodi intaktās saites iestiepj kaula fragmentus pareizā pozīcijā (ligamentotakse). Pieņemot, ka šis process dzīvē patiesi darbojas, ir piedāvāts vēl viens lūzuma repozīcijas mehānisma izskaidrojums - locītavas distrakcijas rezultātā samazinātais intraartikulārais spiediens iedarbojas ar sūkṇa efektu uz mazajiem artikulārajiem fragmentiem un neḷauj tiem sekundāri dislocēties (Schuind et al., 1997). Diemžēl šis mehānisms darbojas tikai uz svaigiem lūzumiem, tādēḷ ĀFA aplikāciju rekomendē veikt pirmo 72 stundu laikā pēc traumas, jo vēlāk sasniegt labu fragmentu repozīciju bez papildu manipulācijām ar fragmentiem ir sarežğîti.

Ārējai fiksācijai kā miniinvazīvai un slēgtai ārstēšanas metodei ir arī virkne komplikāciju. Kopējo uzskaitīto komplikāciju skaits dažāados literatūras avotos atšḳiras, jo autori izvēlējušies atšķirīgus vērtēšanas kritērijus. Senākos rakstos labus un izcilus rezultātus pēc spieḳkaula distālā gala lūzuma ārstēšanas ar ĀFA konstatē 83 līdz $92 \%$ pacientu (bez detalizētas komplikāciju analīzes) (Jakim et al., 1991; Seitz et al., 1991), savukārt jaunākos detalizētos aprakstos, kuros apkopota ikviena pacienta sūdzība vai objektīvā stāvokḷa izmaiņa, komplikāciju biežums variē no 38 līdz 48,5 \% ar piebildi, ka lielākā daļa no tām uzskatāmas 
par nebūtiskām (minor complications) (Farah et al., 2014; Hayes et al., 2008). Biežākās komplikācijas ĀFA un stiepḷu lietošanas gadījumos ir pirkstu stīvums, kas var rasties no plaukstas locītavas pārstiepšanas ar ĀFA, radiālā nerva dorsālā ādas zara bojājums, lūzuma sekundāra dislokācija vai sadzī̌sana anatomiski nepareizā stāvoklī (Richard et al., 2011). Latvijā (bijušajā Latvijas PSR) prof. Mārcis Krūmiṇš 1984. gadā aizstāvēja doktora disertāciju par tēmu "Spieķkaula distālās metafīzes lūzumu ārstēšana ar Kalnbērza kompresijas-distrakcijas aparātu". Šajā zinātniskajā pētījumā tika konstatēts, ka ar Kalnbērza ĀFA dažādām versijām var veiksmīgi ārstēt ne tikai ekstraartikulārus lūzumus, bet arī artikulārus, vaḷējus un nepareizi saaugušus lūzumus. Pozitīvu ārstēšanas rezultātu īpatsvars ar šī ĀFA lietošanu sasniedza $94,4 \%$.

\subsection{Spieḳkaula distālā gala lūzumu ārstēšana ar VLP}

Pēdējo 15 gadu laikā, pieaugot tendencei aizvien biežāk lūzumus ārstēt ḳirurğiski, par galveno spieḳkaula distālo galu lūzumu ārstēšanas metodi ir kḷuvušas dažādu ražotāju piedāvātās volārās bloḳējošās plāksnes (VLP). Bloḳējošās plāksnes darbojas kā iekšējais fiksators, kura skrūves tiek bloḳētas plāksnes atverēs, nodrošinot paredzamu stabilitāti kaula sadrumstalotajās zonās līdz lūzuma pilnīgai konsolidācijai. Ieviešot multivirzienu fiksētā leṇķa plāksnes (multidirectional fixed-angle plate), skrūves ir iespējams nostiprināt plāksnes atverēs dažādos virzienos ar $15^{\circ}$ deviāciju no perpendikulārās pozīcijas. Šis tehniskais risinājums ḷauj novietot skrūves atbilstoši konkrētā lūzuma konfigurācijai un adaptēt plāksnes novietojumu pret kaula volāro malu (Mehrzad and Kim, 2016). Plāksnes distālā gala dizains ḷauj novietot bloḳētās skrūves maksimāli tuvu subhondrālajai zonai, kurā ir visizturīgākais kaula slānis. Precīzāk izpētot spieḳkaula distālā gala anatomiskās īpatnības, rokas ķirurg̣ijā tika ieviests jauns termins - ūdenslīnija (watershead line), ar kuru apzīmē distālāko plāksnes novietojuma zonu, lai izvairītos no saliecējcīpslu jatrogēna bojājuma (sk. 1.14. A un 1.14. B attēlu). 

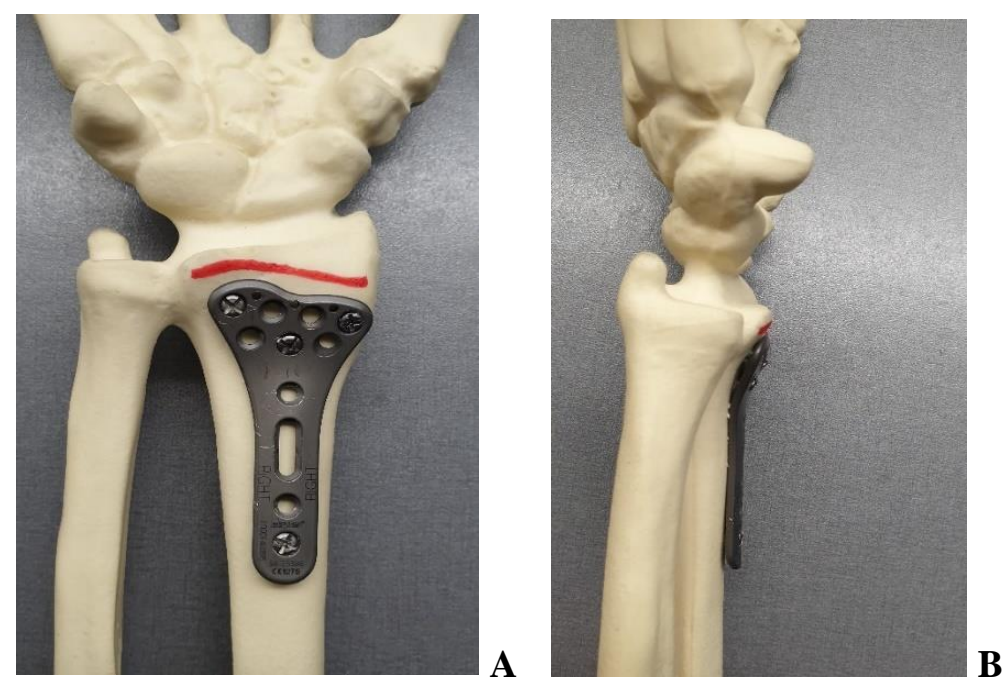

1.14. attēls. Watershead line un plāksnes pareizs novietojums AP un LL projekcijās (autora veidots modelis un foto)

Plāksnes distālā un palmārā novietojuma raksturošanai izmanto Soong līnijas, kur Soong $O$ apzīmē plāksnes optimālu novietojumu, Soong $I$ - plāksnes distālais gals palmārā pusē izvirzās ārpus spieḳkaula anatomiskajām robežām, Soong II - plāksnes distālais gals izvirzās ārpus spieḳkaula palmārajām un distālajām anatomiskajām robežām, un tas nozīmē, ka metāla konstrukcija obligāti ir jāevakuē (sk. 1.15. attēlu).

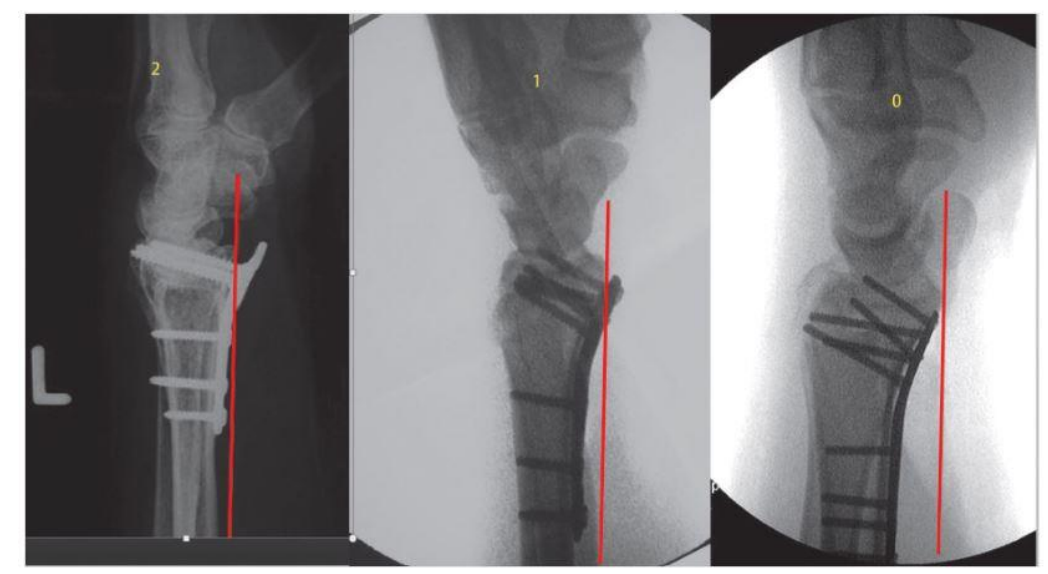

1.15. attēls. Soong kritēriji

Lai izvairītos no atliecējcīpslu jatrogēnu bojājumu radīšanas, distālajām skrūvēm ir jābūt vismaz par 2 mm īsākām nekā nomērītajam skrūves kanālam. Biomehāniski tas neradīs repozīcijas nestabilitāti, jo skrūves ar galvin̄ām rigidi fiksējas plāksnes atverēs (Baumbach et al., 2015). Ir izšķiroši būtiski izvairīties no skrūvju galu izvelvēšanās virs dorsālā kortikālā slāņa. Šaubu gadījumos skrūvju garumu un novietojumu var pārbaudīt ar RTG veikšanu specifiskās pozīcijās (skyline view, dorsal horizontal view) (Joseph and Harvey, 2011). Nemot vērā spieķkaula distāla gala trīsstūrveida formu, parastajās standarta RTG pozīcijās, implantējot VLP, var šķist, ka distālās skrūves ir novietotas intraartikulāri. Lai pārliecinātos par skrūvju 
pareizu pozicionēšanu subkortikāli, nepieciešams veikt RTG izmeklējumus laterālā pozīcijā (LL) $20^{\circ}$ līdz $23^{\circ}$ pacēlumā (tilted view), savukārt taisnajā projekcijā (AP) $-10^{\circ}$ līdz $11^{\circ}$ pacēlumā (Boyer et al., 2004) (sk. 1.16. A un 1.16. B attēlu).
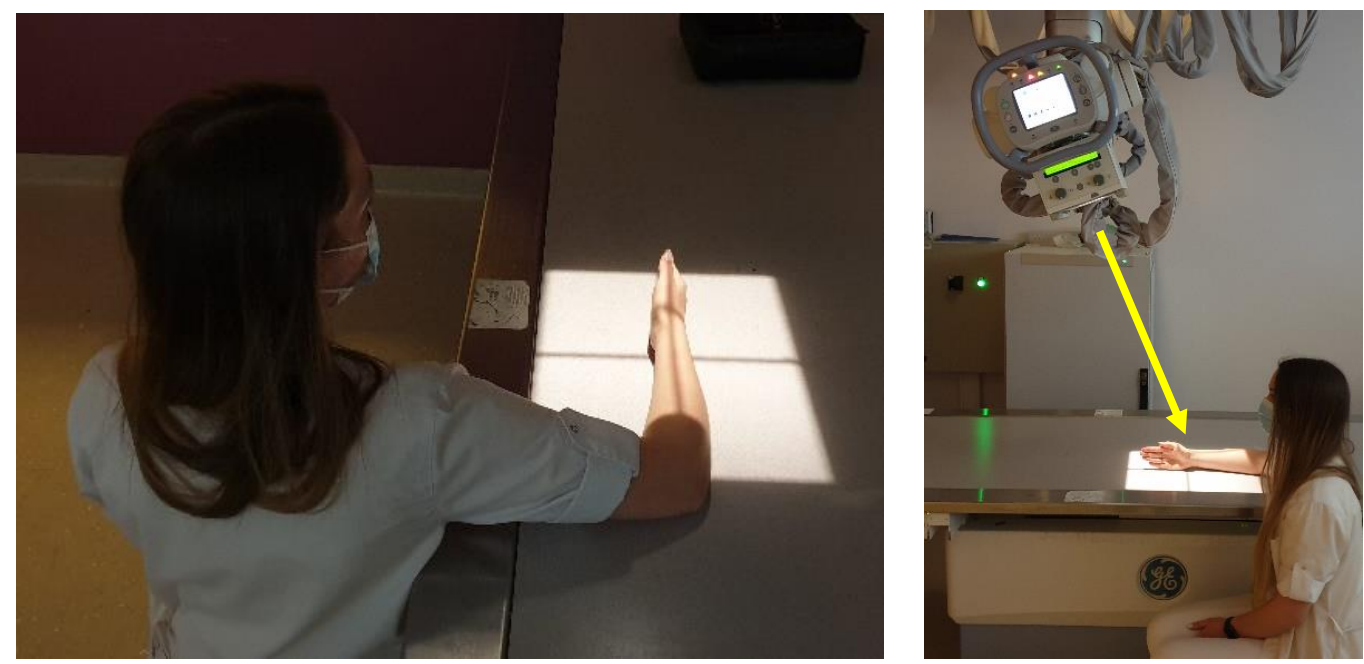

1.16. A attēls. $\mathbf{L L} \mathbf{2 0}^{\circ}$ tilted view (autora foto)
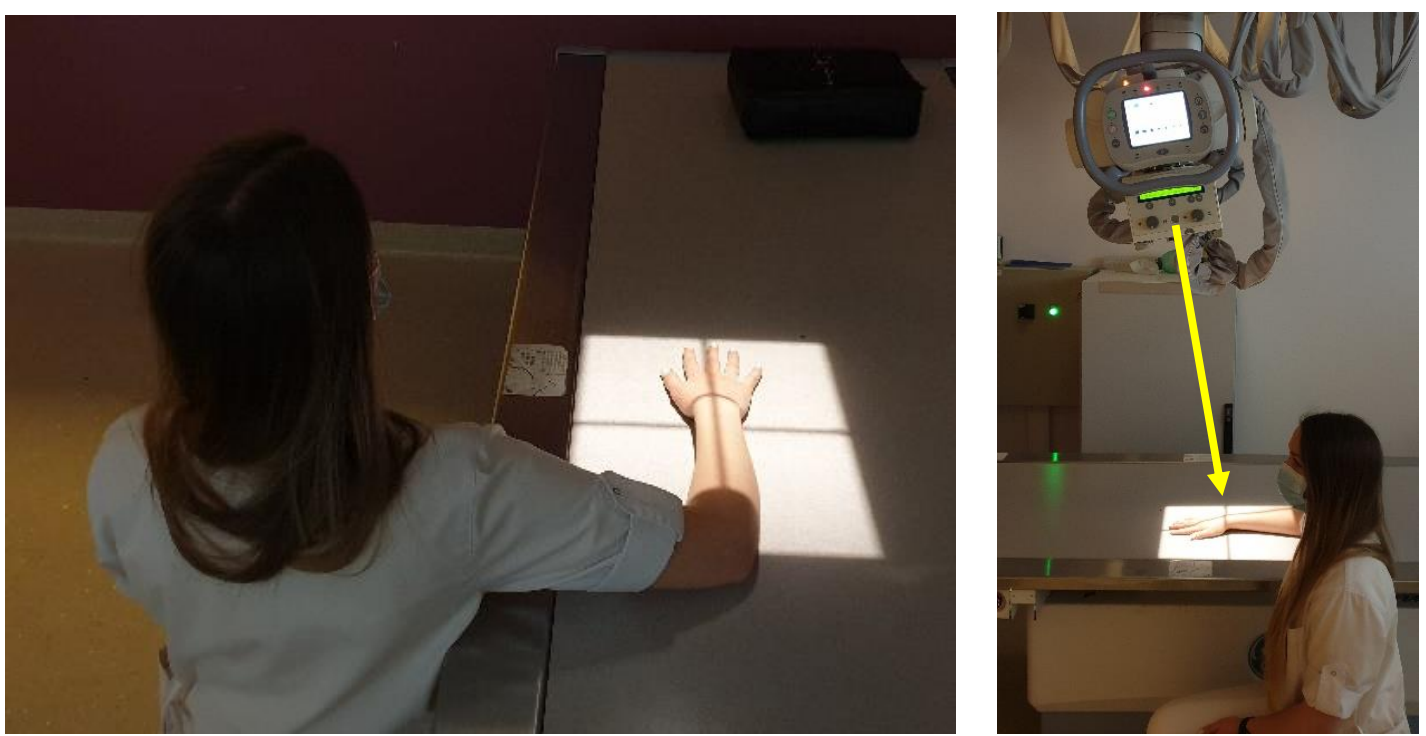

1.16. B attēls. AP $10^{\circ}$ tilted view (autora foto)

\subsection{Artroskopiski asistēta spieḳkaula distālo artikulāro lūzumu ārstēšana}

Plaukstas ķirurgi sāka lietot artroskopiju spieḳkaula distālo galu lūzumu ķirurǵiskajā ārstēšanā pagājušā gadsimta 90. gadu beigās. Artikulāro lūzumu ārstēšanas funkcionālos rezultātus nosaka ekstraartikulāro lūzuma fragmentu izlīdzināšana, atjaunojot kaula formu, garumu un ieloces, locītavas virsmas fragmentu anatomiska repozīcija, mīksto audu papildu bojājumu novēršana, kā arī iespējamās pēcoperācijas komplikācijas, kā visiem periartikulāriem vai intraartikulāriem lūzumiem (Catalano et al., 2004; Fernandez and Geissler, 1991; Geissler et al., 1996; Mehta et al., 2000; Wadsten et al., 2017). Ņemot vērā šos aspektus, plaukstas 
locītavas artroskopija ir atzīta par svarīgu, ārstēšanas procesu papildinošu un labāku rezultātu nodrošinošu procedūru, kura ḷauj kvalitatīvāk izvērtēt un veikt locītavas virsmu veidojošo fragmentu repozīciju un fiksāciju, kā arī diagnosticēt un novērst (ārstēt) dažādus papildu mīksto audu bojājumus (Del Pinal, 2011; Doi et al., 1999; Lindau, 2017; Ruch et al., 2004). Artroskopiskā metode noteikti ir pārāka par tikai fluoroskopiski kontrolētu artikulāro fragmentu repozīcijas metodi. Līdz pat $30 \%$ atlikušo fragmentu deformāciju fluoroskopiski nav iespējams verificēt (Ardouin et al., 2018; Lutsky et al., 2008; Varitimidis et al., 2008). Izmantojot plaukstas locìtavas artroskopiju, locìtavu var attīìit no asins recekḷiem, mazinot posttraumatisko intraartikulāro adhēziju veidošanās risku, evakuēt sīkos kaulu fragmentus un vizualizēt hondrālos defektus (Lutz et al., 2011). Mīksto audu asociētos bojājumus konstatē no 30 līdz 50 \% gadījumu, taču ir būtiski pieminēt, ka līdz šim nav konkrēti pierādīta saistība starp šo bojājumu (SLIL, LTIL, TFCC) diagnosticēšanu, ārstēšanu un pacientu funkcionālo uzlabojumu pēc operācijas (Swart and Tang, 2017).

Veicot artroskopiski asistēto spieḳkaula distālo galu lūzumu ārstēšanu, tiek izmantoti standarta plaukstas artroskopijas portāli (sk. 1.17. un 1.18. attēlu) (skatīt arī tabulas par portālu lokalizāciju un funkcijām), kā arī papildus volārie portāli.

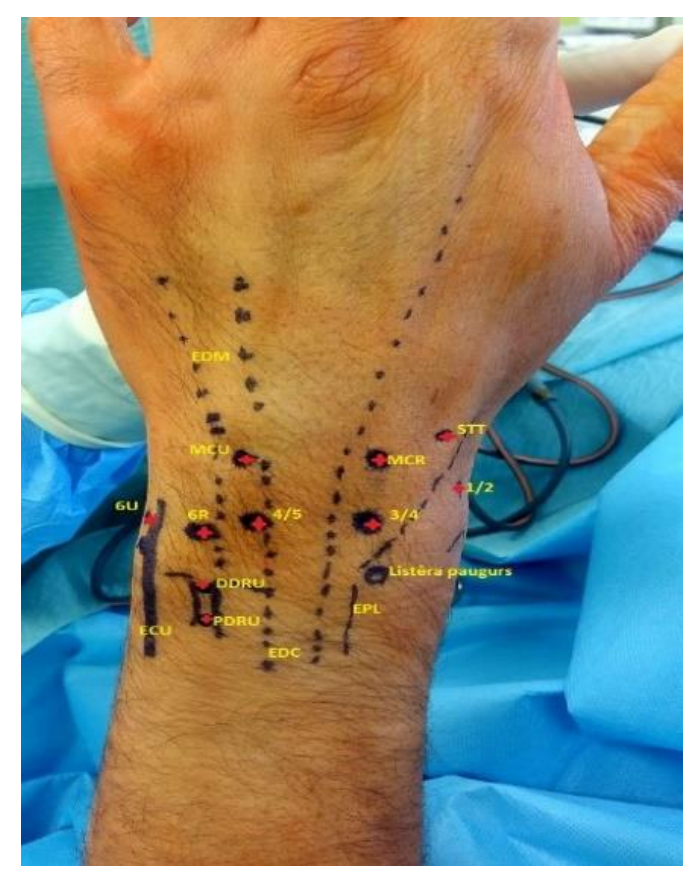

1.17. attēls. Dorsālie plaukstas portāli (autora foto)

MCR - midkarpālais radiālais portāls; MCU - midkarpālais ulnārais portāls;

STT - scaphotrapezium-trapezoideum portāls; DDRU - dorsālais distālās radioulnārās locìtavas portāls;

PDRU - proksimālais distālās radioulnārās locītavas portāls; ECU - m. extensor carpi ulnaris cīpsla;

$\mathrm{EDC}-m$. extensor digitorum communis cīpsla; $\mathrm{EDM}-m$. extensor digiti minimi cīpsla;

$\mathrm{EPL}-$ m .extensor pollicis longus cīpsla; 1/2, 3/4, 4/5, 6R, 6U - radiokarpālie portāli. 


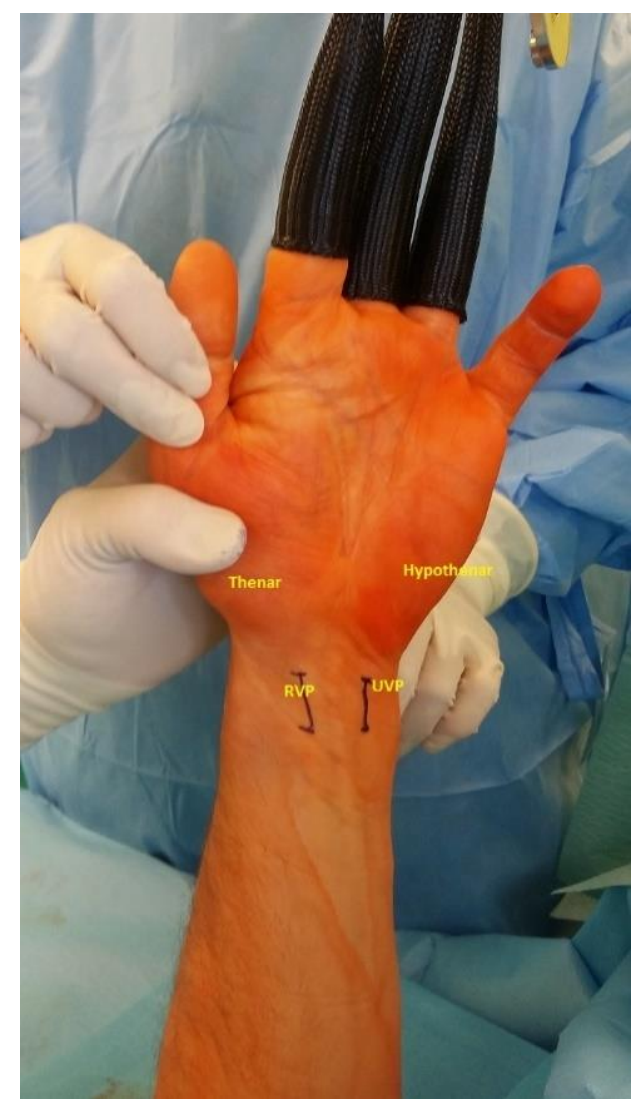

1.18. attēls. Volārie plaukstas portāli (autora foto)

$\mathrm{RVP}$ - radiālais volārais portāls; UVP - ulnārais volārais portāls.

1.2. tabula

Radiokarpālie portāli

\begin{tabular}{|c|c|c|}
\hline Portāls & Lokalizācija un funkcija & $\begin{array}{c}\text { Riska struktūras } \\
\text { (potenciāli traumējamas) }\end{array}$ \\
\hline $1-2$ & $\begin{array}{l}\text { Starp APL un ECRB cīpslām anatomiskās tabakdozes } \\
\text { dorsālajā pusē. Retāk lietojams, galvenokārt, lai sasniegtu } \\
\text { spiekkkaula îlenveida izaugumu un locitavas radiālo pusi } \\
\text { vai lai izmantotu skalošanai }\end{array}$ & $\begin{array}{l}\text { a. radialis, } \\
\text { n. radialis virspusējais zars }\end{array}$ \\
\hline $3-4$ & $\begin{array}{l}1 \mathrm{~cm} \text { distāli no Listēra paugura starp EDC un EPL } \\
\text { cīpslām. Vienmēr veido kā primārās vizualizācijas portālu }\end{array}$ & EPL un EDC cīpslas \\
\hline $4-5$ & $\begin{array}{l}\text { 4. delnas (metakarpālā) kaula ass starp EDC un EDM } \\
\text { cīpslām. Portāls instrumentiem un TFCC vizualizācijai }\end{array}$ & EDC un EDM cīpslas \\
\hline $6 \mathrm{R}$ & $\begin{array}{l}\text { Pie ECU cīpslas radiālās malas. Papildu portāls } \\
\text { instrumentiem vai vizualizācijai, TFCC ulnārās daḷas } \\
\text { rekonstrukcijai }\end{array}$ & n. ulnaris dorsālais zars \\
\hline $6 \mathrm{U}$ & $\begin{array}{l}\text { Pie ECU cīpslas ulnārās malas. Primārais papildu portāls } \\
\text { instrumentiem vai vizualizācijai, TFCC ulnārās daḷas } \\
\text { rekonstrukcijai }\end{array}$ & n. ulnaris dorsālais zars \\
\hline RVP & $\begin{array}{l}2 \mathrm{~cm} \text { grieziens paralēli FCR cīpslai. Tiek izmantots DRCL } \\
\text { un SLIL volārās daḷas izvērtēšanai }\end{array}$ & $\begin{array}{l}\text { n. radialis palmārais ādas } \\
\text { zars }\end{array}$ \\
\hline UVP & $\begin{array}{l}2 \mathrm{~cm} \text { grieziens paralēli saliecējcīpslu ulnārajai malai. Tiek } \\
\text { izmantots LTIL volārās dal̦as izvērtēšanai }\end{array}$ & $\begin{array}{l}\text { n. ulnaris distālais } \\
\text { palmārais ādas zars }\end{array}$ \\
\hline
\end{tabular}

APL - m. abductor pollicis longus cīpsla; DRCL - dorsal radio-carpal ligament; ECRB - m. extensor carpi radialis; ECRL - m. extensor carpi radialis longus; ECU - m. extensor carpi ulnaris; EDC - m. extensor digitorum communis; EDM - m. extensor digiti minimi; EPL - m. extensor pollicis longus; FCR - m. flexor carpi radialis; TFCC - triangular fibrocartilage complex. 
Midkarpālie portāli

\begin{tabular}{|l|l|l|}
\hline Portāli & \multicolumn{1}{|c|}{ Lokalizācija un funkcija } & \multicolumn{1}{c|}{$\begin{array}{c}\text { Riska struktūras } \\
\text { (potenciāli traumējamas) }\end{array}$} \\
\hline MCR & $\begin{array}{l}\text { Lokalizēts 1 cm distāli no 3/4 portāla starp ECRB un } \\
\text { EDC cīpslām. Iespēja vizualizēt locītavas: } \\
\text { SL (art. scapholunate), SC (art. scaphocapitate) } \\
\text { un STT (art. Scaphotrapezium-trapezoideum) }\end{array}$ & ECRB un EDC cīpslas \\
\hline MCU & $\begin{array}{l}\text { Lokalizēts 1 cm distāli no 4/5 portāla, pa 4. delnas } \\
\text { (metakarpālā) kaula asi, starp EDC un EDM cīpslām. } \\
\text { Lauj vizualizēt LT (art. lunato-triqutrale), LC (art. } \\
\text { lunato-capitatum) un TH (art. triquetrale-hamato) }\end{array}$ & EDC un EDM cīpslas \\
\hline STT & $\begin{array}{l}\text { Lokalizēts pa 2. delnas (metakarpālā) kaula asi ulnāri } \\
\text { no EPL cīpslas STT locītavas (art. scaphotrapezium- } \\
\text { trapezoideum) līmenī }\end{array}$ & ECRB un ECRL cīpslas \\
\hline
\end{tabular}

ECRB - m. extensor carpi radialis; ECRL - m. extensor carpi radialis longus; EDC - m. extensor digitorum communis; EDM - m. extensor digiti minimi; EPL - m. extensor pollicis longus; MCR - midkarpālais radiālais portāls; MCU - midkarpālais ulnārais portāls; STT - scaphotrapezium-trapezoideum portāls.

Plaukstas artroskopijas var veikt divās dažādās tehnikās - tā sauktajā slapjajā, kad visu laiku izmanto sterila fizioloǵiskā šķidruma ievadīšanu locītavā, un tā sauktajā sausajā tehnikā, kad manipulācijas notiek iestieptas plaukstas locītavas lūmenā bez pastāvīgas šḳidruma klātbūtnes, veicot tikais locītavas periodisku izskalošanu, lai uzlabotu redzes lauku un evakuētu asins recekḷus (Del Pinal, 2011). Locītavas inspekciju artroskopiski labāk veikt pēc prelimināras lūzuma fragmentu repozīcijas un fiksācijas. Neadekvāti esošo fragmentu pārdislocēšanai rekomendē izmantot artroskopisko zondi vai stieples, kuras, ieurbjot fragmentos, izmanto kā manipulatorus. Artroskopiski var arī konstatēt stiepḷu vai skrūvju nepareizu lokalizāciju - piemēram, atrašanos intraartikulāri, ko tūlītēji ir iespējams novērst, mazinot DOA veidošanās risku. Lieliski ilustrētus artroskopiskās spieḳkaula distālo lūzumu ārstēšanas metožu aprakstus ir publicējuši vairāki autori (Ardouin et al., 2018; del Pinal, 2011; Lutz et al., 2011). Plaukstas artroskopijas šobrīd rekomendē lietot jebkura artikulārā spieķkaula distālā lūzuma ārstēšanā, tomēr ir apzinātas dažas iespējamās kontrindikācijas. Kā viena no tām ir gados veci un mazaktīvi pacienti, vaḷēji lūzumi, kā arī politraumas pacienti, īpaši agrīnajā ārstēšanas posmā, jo š̄ procedūra var ievērojami palielināt operācijas laiku. Kā vēl viena būtiska iebilde artroskopiskās ārstēšanas lietošanai ir tehniskā ekipējuma un ķirurga pieredzes trūkums (Abe, 2014; del Pinal, 2011; Kastenberger et al., 2020). 


\section{Pētnieciskā daḷa}

\subsection{Pētījuma uzbūve}

Šis ir prospektīvs, longitudināls pētījums, dalot pacientus divās salīdzināmajās grupās ar alternatīvās allokācijas metodi. Mērḳa populācija - abu dzimumu pacienti, kas sasnieguši 15 gadu vecumu un guvuši spieķa kaula $\mathrm{C} 1, \mathrm{C} 2$ vai C3 tipa lūzumu vienai rokai (veselā roka paredzēta funkcionālai salīdzināšanai). Lūzumu rentgenogrammas tika izvērtētas pēc AO klasifikācijas, ieviešot papildu korekcijas lūzumu iedalīšanai vienā vai citā grupā, n,emot vērā operācijas laikā iegūto informāciju (piemēram, artroskopijas laikā konstatēts lielāks artikulāro fragmentu skaits, nekā redzams parastajās rentgenogrammās).

Pêtījumam nepieciešamo dalībnieku skaitu un pētījuma statistisko jaudu aprēḳināja, pamatojoties uz literatūrā pieejamiem datiem par plaukstas spēka mērījumiem (satvēriens kā galvenais) un PRWE anketas punktu skaitu minimālo klīniski nozīmīgo atšḳirību (MKNA). Plaukstas satvēriena MKNA ir ap 6,5 kg jeb 19,5 \% no pretējās plaukstas spēka (Kim et al., 2014). Pēc šiem datiem aprēķināts, ka pētījumam ar 80 \% jaudu pietiktu vien ar 10 pacientiem katrā grupā. Savukārt vērā ņemamāks ir izlases apjoma aprēḳins, izmantojot pieejamos datus par PRWE, kas ir $11 \pm 14$ punkti MKNA (Walenkamp et al., 2015). Izlases apjoma aprēķinā secināts, ka nepieciešami kopumā 50 pacienti hipotēzes apstiprināšanai vai noraidīšanai (25 pacienti katrā grupā). Pieņemot, ka $30 \%$ pacientu pārtrauks līdzdalību pētījumā, nepieciešams iesaistīt vismaz 71 pacientu. Diemžēl vēl aizvien literatūrā nav pieejamu pētījumu par MKNA plaukstas locītavas kustību daudzumu, kā arī pētījumā tika izmantotas skalas MASS07 un Gartlan and Werley modifikācija, kam nav izstrādāti MKNA, lai tos varētu ṇemt vērā izlases aprēḳinos. Pētāmās grupas lielums tika aprēḳināts ar 80 \% pētījuma jaudu pēc formulām (sk. 2.1. attēlu).

$$
\begin{aligned}
& k=\frac{n_{2}}{n_{1}}=1 \\
& n_{1}=\frac{\left(\sigma_{1}^{2}+\sigma_{2}^{2} / K\right)\left(z_{1-\alpha / 2}+z_{1-\beta}\right)^{2}}{\Delta^{2}} \\
& n_{1}=\frac{\left(10^{2}+10^{2} / 1\right)(1.96+0.84)^{2}}{10^{2}} \\
& n_{1}=16 \\
& n_{2}=K * n_{1}=16 \\
& \quad \\
& \quad \begin{array}{l}
\Delta=\left|\mu_{2}-\mu_{1}\right|=\text { absolute difference between two means } \\
\sigma_{1}, \sigma_{2}=\text { variance of mean } \# 1 \text { and } \# 2 \\
\mathrm{n}_{1}=\text { sample size for group } \# 1 \\
\mathrm{n}_{2}=\text { sample size for group } \# 2 \\
\alpha=\text { probability of type I error (usually } 0.05) \\
\beta=\text { probability of type II error (usually } 0.2) \\
\mathrm{z}=\text { critical } \mathrm{Z} \text { value for a given } \alpha \text { or } \beta \\
\mathrm{k}=\text { ratio of sample size for group } \# 2 \text { to group } \# 1
\end{array}
\end{aligned}
$$

\section{1. attēls. Pētāmās grupas lielums, kas aprēḳināts ar 80 \% pētījuma jaudu} pēc attēlotajām formulām 
Pēc veicamās operācijas metodes noteikšanas pacientus iedalīja VLP grupā vai ĀFA grupā atbilstoši pieņemtajai randomizācijas metodei. Tika veikta ķirurğiskā ārstēšana - vaḷeja repozīcija un osteosintēze ar volāro bloḳēto plāksni vai minimāli invazīva osteosintēze ar stieplēm un monolaterālu ārējās fiksācijas aparātu no dorsālās virsmas. Operācijas tika veiktas paduses nervu bloka (axillary block) vai vispārējā anestēzijā (pēc anesteziologa ieskatiem un / vai tehniskajām iespējām). Abas osteosintēzes tika veiktas plaukstas artroskopijas kontrolē, lai vizualizētu artikulāro fragmentu savstarpējo novietojumu, mazinātu pēcoperācijas intraartikulāro adhēziju veidošanos un vizualizētu papildu mīksto audu traumas - TFCC vai interkarpālo saišu bojājumus. Artroskopijas laikā konstatētā interkarpālo saišu bojājuma pakāpe tika vērtēta pēc Geissler klasifikācijas (sk. 1.1. tabulu), savukārt TFCC bojājums vērtēts pēc Palmer klasifikācijas (sk. 2.1. tabulu un 2.2. attēlu).

2.1. tabula

Palmer klasifikācija akūtiem (traumatiskiem) TFCC bojājumiem

\begin{tabular}{|l|l|}
\hline A & Centrāla TFCC perforācija \\
\hline B & Perifēra ulnāra TFCC avulsija (ar vai bez proc. styloideus ulnae lūzumu) \\
\hline C & Distāla TFCC avulsija (atrāvums no DUC saites) \\
\hline D & Radiāls TFCC bojājums (ar vai bez sigmoīdās ieloces lūzuma) \\
\hline
\end{tabular}

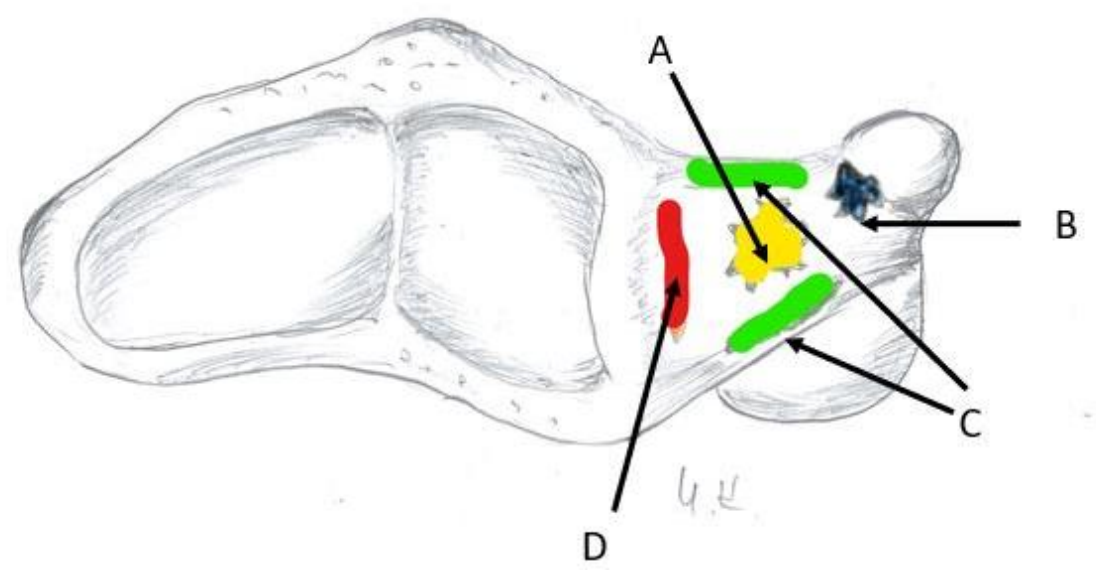

2.2. attēls. TFCC plīsumi pēc Palmer (autora zīmējums)

Pirms pētîjuma uzsākšanas tika definētas pieḷaujamās novirzes: < $1 \mathrm{~mm}$ starp fragmentiem, spieķa kaula sāisinājums $<5 \mathrm{~mm}$, salīdzinot ar veselo roku, radiālās inklinācijas leṇkisis $>15^{\circ}$, volārā pārkare $<-10^{\circ}$. Iespēju robežās tika veikti visi pasākumi, lai spieḳkaula distālā gala anatomija tiktu atjaunota maksimāli precīzi. 


\subsection{Operācijas protokols pacientiem ar VLP lietošanu}

Anesteziologa izvēlētajā anestēzijā pēc operācijas lauka aseptiskas apdares tiek uzlikts arteriāls manšetes žņaugs augšdelma distālajai trešdaḷai un uzpildīts ar spiedienu no 280 līdz $320 \mathrm{~mm}$ Hg. Operējamā roka tiek novietota uz rokas galdiņa. Tiek izdarīts ādas grieziens ar tā saukto paplašināto volāro pieeju, t. i., pamata grieziens ir lineārs paralēli FCR cīpslas gaitai, savukārt distālajā galā veido V-veida griezienu processus styloideus radii virzienā un pēc tam atpakal uz plaukstas locītavas volārās virsmas vidusdaḷu, nešḳērsojot karpālās saites zonu. Ādas grieziena kopējais garums ir 8-10 cm. Ar šādu grieziena distālās daḷas izvietojumu ir iespējams vizualizēt visu spieķkaula distālo galu un tas atvieglo gan lūzuma fragmentu vizualizāciju, gan plāksnes ievietošanu. Pēc ādas un zemādas šḳelšanas asā un trulā veidā virzās brūces dziḷumā. Šḳeḷ fasciju virs FCR cīpslas. Brūces dziḷumā virzās starp FCR cīpslu un radiālo neirovaskulāro kūlīti, kuru saudzīgi izpreparē un atbīda radiāli. L-veid̄̄gi šḳeḷ m.pronator quadratus caur tā šḳiedraino daḷu, muskuli retrahē ulnāri un skeletizē lūzuma zonu. Veic hematomas evakuāciju, vaḷēju volāro fragmentu repozīciju redzes kontrolē un prelimināru fiksāciju ar Kiršnera stieplēm.

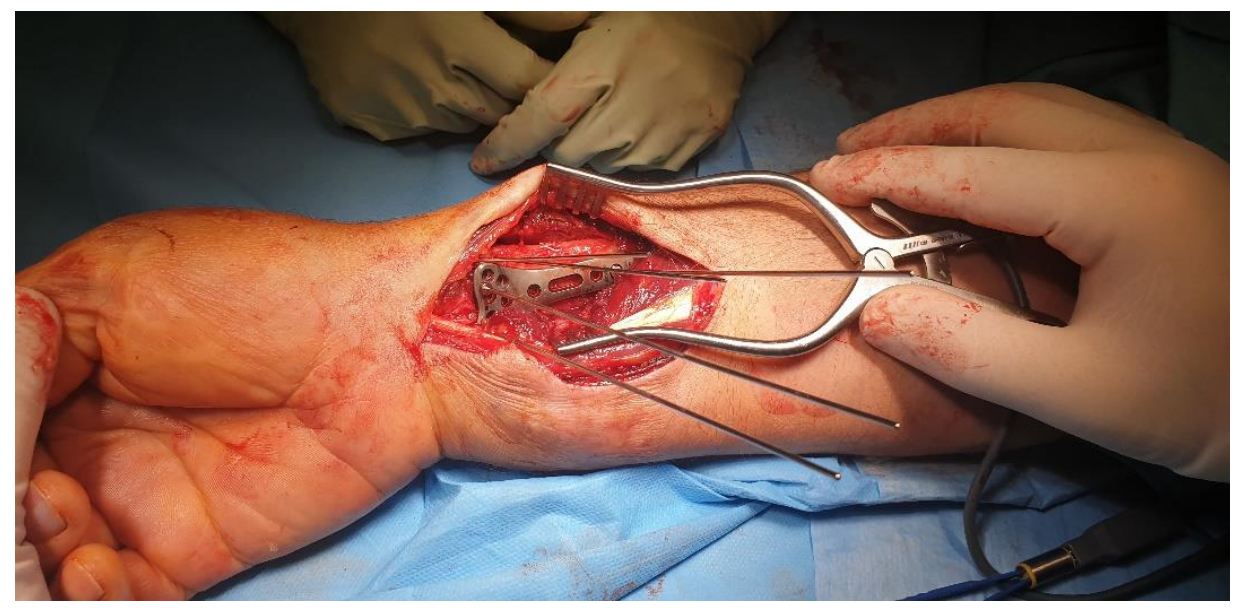

2.3. attēls. Standarta volārā pieeja, plāksnes pagaidu fiksācija ar stieplēm pēc primārās repozīcijas

Tiek veikta RTG kontrole un plāksnes fiksācija pie spieḳkaula diafīzes ar skrūvēm. Distālo metafìzi šajā etapā fiksē ar pagaidu stieplēm caur plāksni un operējamo roku novieto plaukstas artroskopijas tornī. Tiek veikta plaukstas locītavas distrakcija (ligamentotakse). Izveido 3.-4. un 4.-5. portālu. Veic asiṇu un asins recekḷu evakuāciju no plaukstas locītavas, to izskalo un vizualizē lūzuma zonas. Artroskopijas kontrolē, ja nepieciešams, mainot vizualizācijas portālus, tiek veikta manuāla lūzuma fragmenta papildu repozīcija ar stieplēm vai kaula spailēm un fiksācija. 


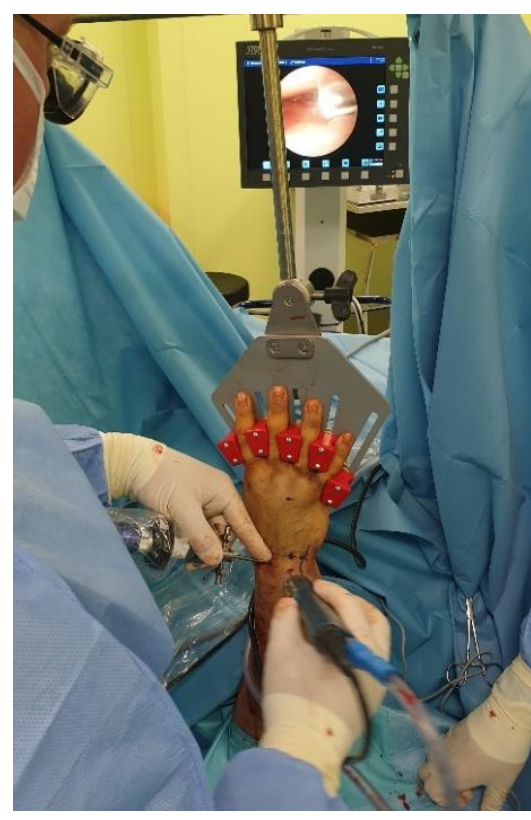

\section{4. attēls. Plaukstas fiksācija artroskopijas tornī un artroskopiskais operācijas etaps}

Ja, inspicējot locītavu, konstatē TFCC plīsumu vai arī interkarpālo saišu bojājumus, tiek veiktas papildu manipulācijas atbilstoši šo bojājumu novēršanas algoritmiem. Pēc artroskopiskā etapa tiek veikta plāksnes fiksācija ar skrūvēm. Atkārtoti veic fluoroskopijas kontroli. Dažādos virzienos grozot plaukstas locītavu, pārliecinās par implantēto konstrukciju garumu. Ja lūzuma fiksācija palpatori un vizuāli ir stabila, sašuj m.pronator quadratus. Brūci drenē ar aktīvās aspirācijas drenu un slēdz pa kārtām. Liek aseptisku pārsēju. Plaukstas locītavu fiksē īsajā gipša longetē.

\subsection{Operācijas protokols pacientiem ar ĀFA lietošanu}

Anesteziologa izvēlētajā anestēzijā pēc operācijas lauka aseptiskas apdares tiek uzlikts arteriāls manšetes žņaugs augšdelma distālajai trešdaļai un uzpildīts ar spiedienu no $280 \mathrm{lī} d z$ 320 mm Hg. Operējamā roka tiek novietota uz rokas galdiņa. Sākotnēji fluoroskopijas kontrolē veic lūzuma fragmentu primāro repozīciju un fiksāciju ar vairākām stieplēm, cenšoties panākt labāko iespējamo fragmentu repozīciju. Tālākajā etapā operējamo roku fiksē plaukstas artroskopijas torn̄̄ un veic plaukstas locītavas distrakciju (ligamentotaksi). Izveido 3.-4. un 4.5. portālu. Ievada locītavā artroskopu un manipulatorus. Locītavā veic asins recekḷu un sīko kaulu fragmentu evakuāciju ar šeiveri. Vizualizē lūzuma zonu un fragmentus. Ja nepieciešams, veic fragmentu papildu repozīciju artroskopijas kontrolē un fiksāciju ar stieplēm dažādos virzienos. Veic atkārtotas fluoroskopiskās kontroles, līdz tiek iegūts apmierinošs kaula fragmentu vizuālais un rentgenologiskais stāvoklis. Ja nepieciešams, šajā operācijas etapā tiek veiktas manipulācijas asociēto mīksto audu bojājumu novēršanai. 
Nenoṇemot roku no artroskopijas torņa un nesamazinot plaukstas locītavas iestiepumu, tiek veikta papildu stabilizācija ar ĀFA.

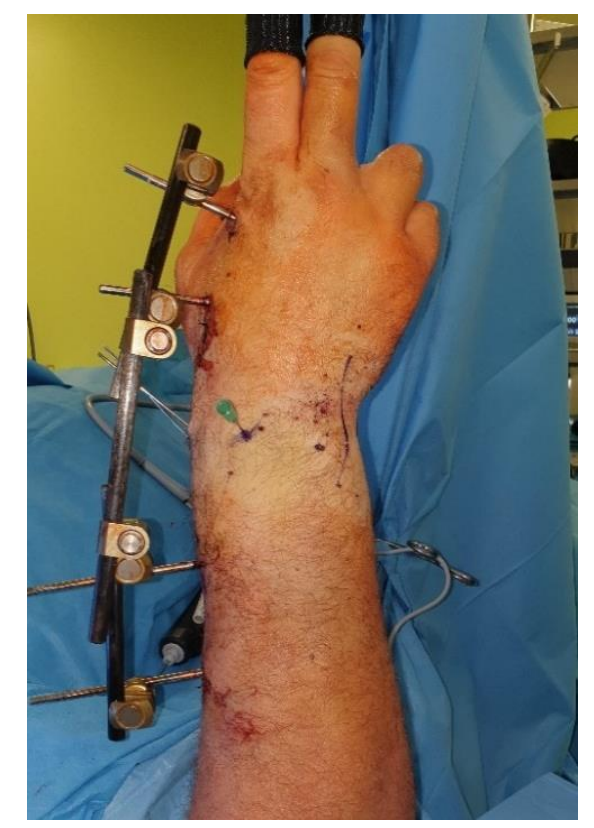

\section{5. attēls. ĀFA aplikācija pēc artroskopiskas lūzuma fiksācijas ar stieplēm}

Šim mērķim 2. metakarpālā kaula dorsoradiālā virsmā ievada divus ĀFA savienotājmezgla atverēm atbilstošus, paralēlus vītṇstieņus un spieḳkaula diafīzē proksimāli no lūzuma dorsoradiālajā virsmā ievada vēl divus vītṇstienus. Starp kaulā ievadītajiem implantiem montē un safiksē ĀFA mezglus, saglabājot iestiepumu plaukstas locītavas mīkstajos audos. Ievadīto stiepḷu galus noliec, nokniebj un paslēpj zem ādas. Atlaiž žņaugu, veic hemostāzi, brūces slēdz ar virspusējām šuvēm, uzliek aseptiskus pārsējus.

\subsection{Pēcoperācijas protokoli}

Pacientiem ar spieķkaula distālu artikulāru lūzumu, kas operēti ar volāro bloḳējošo plāksni:

1. Nākamajā dienā pēc operācijas - aktīvās aspirācijas drenas evakuācija un pārsēja maiṇa, izrakstīšana no stacionāra tajā pašā vai nākamajā dienā.

2. Pārsēju maiņa reizi 3-4 dienās.

3. Šuvju noṇemšana 12-14 dienas pēc operācijas.

4. Imobilizācija līdz šuvju noṇemšanai.

5. Sākot ar otro pēcoperācijas dienu - pleca, elkoṇa un pirkstu kustību uzsākšana pēc vienota protokola. 
6. Sākot ar trešo pēcoperācijas nedēḷ - plaukstas locītavas aktīvo un pasīvo kustību iestrāde rehabilitologa uzraudzībā.

7. RTG kontrole četras nedēḷas pēc operācijas.

8. Kontroles pie ārstējošā ārsta 1, 3, 6 un 12 mēnešus pēc operācijas.

Pacientiem ar spieḳkaula distālu artikulāru lūzumu, kas operēti ar stieplēm un ĀFA:

1. Nākamajā dienā pēc operācijas - pārsēja maiṇa un izrakstī̌sana no stacionāra.

2. Pārsēju maiṇa reizi 3-4 dienās.

3. Sākot ar otro pēcoperācijas dienu - pleca, elkoṇa un pirkstu kustību uzsākšana pēc vienota protokola.

4. Šuvju noṇemšana $12-14$ dienas pēc operācijas.

5. RTG kontrole četras nedēḷas pēc operācijas.

6. ̄FA un stieplu demontāža 4-6 nedēḷas pēc operācijas.

7. Plaukstas locītavas aktīvo un pasīvo kustību iestrāde MC rehabilitologa uzraudzībā pēc fiksatoru izṇemšanas.

8. Kontroles pie ārstējošā ārsta 1, 3, 6 un 12 mēnešus pēc operācijas.

\subsection{Primāro datu iegūšanas metodes un sekundāro datu avoti}

Katrā vizìtē pacientam tiek veikts:

1. Vizuālais novērtējums, objektīvo datu ieguve - kustību apjoma mērījumi, izmantojot digitālo goniometru, plaukstas un pirkstu tvēriena spēka mērījumi (Grip / Pinch / 3P Pinch) ar Jamar dinamometru, kā arī RTG izmeklējums AP projekcijā ar $10^{\circ}$ pacēlumu un LL projekcijā ar $20^{\circ}$ pacēlumu. RTG izmeklējuma izvērtēšanu veica no pētījuma neatkarīgs radiologs.

2. Iegūto rezultātu fiksēšana un izvērtēšana pēc Gartland \& Werley skalas (iespējamie rezultāti no 17,5 līdz 100, lielāks punktu skaits nozīmē labāku rezultātu), anketēšana ar PRWE (Patient-Rated Wrist Evaluation) (iespējamie rezultāti no 0 līdz 140, mazāks punktu skaits nozīmē labāku rezultātu), MASS07 (Modern Activity Subjective Survey of 2007) (iespējamie rezultāti no 0 līdz 100, mazāks punktu skaits nozīmē labāku rezultātu) tabulām. 


\section{Rezultāti}

\subsection{Vispārējie dati}

Kopumā pētījuma datu apstrādē tika iekḷauti 64 pacienti - 40 sievietes ar vidējo vecumu 55,5 gadi un 24 vīrieši ar vidējo vecumu 43,3 gadi (sk. 3.1. attēlu). Sadalot pacientus pētījuma grupās, izveidojās VLP grupa ar 34 pacientiem, kuru vidējais vecums ir 52,4 gadi, un ĀFA grupa ar 30 pacientiem, kuru vidējais vecums ir 49,2 gadi (sk. 3.2. attēlu).

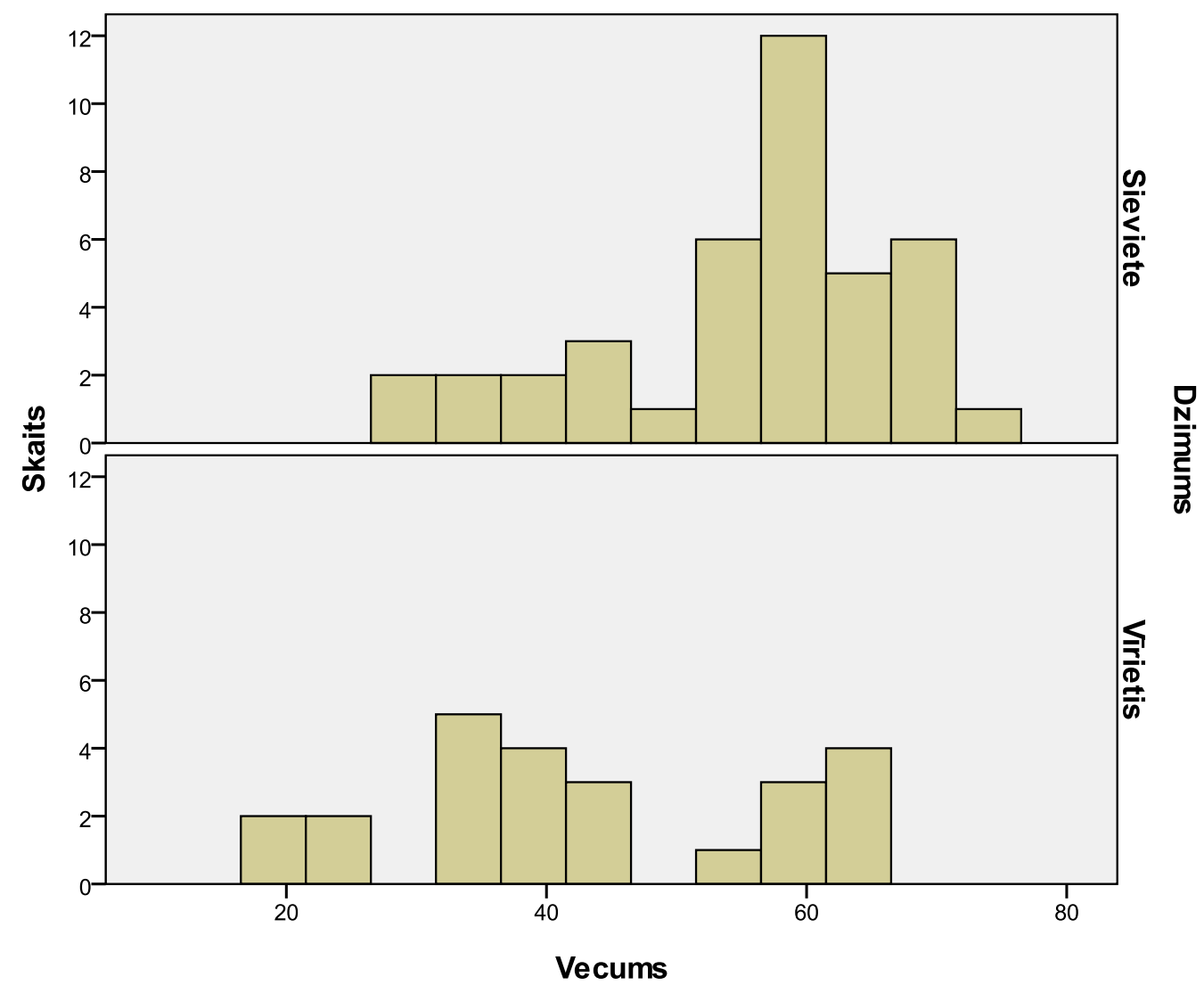

3.1. attēls. Sieviešu un vīriešu vecuma atšḳirību diagramma 


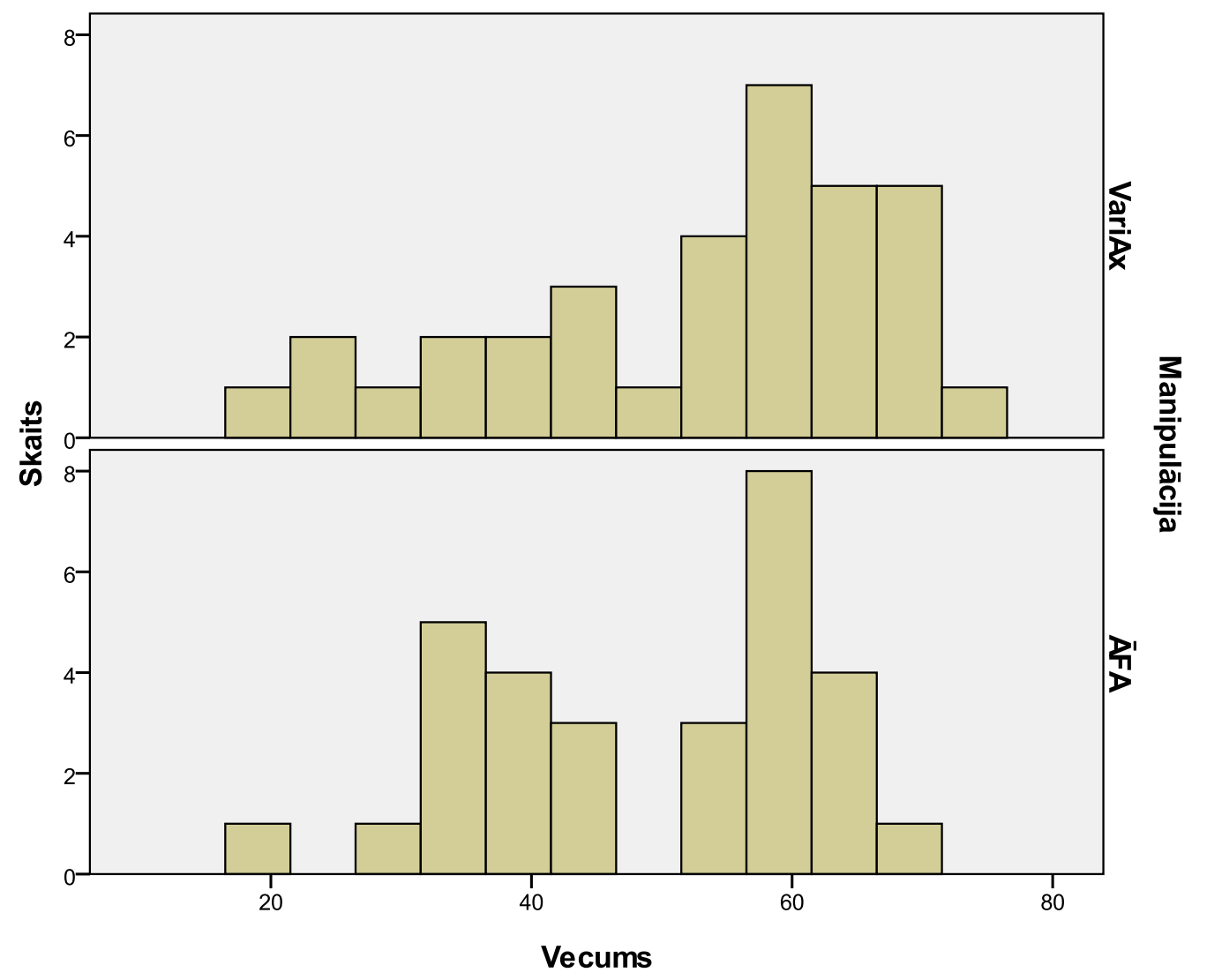

3.2. attēls. Vecuma sadalījuma diagramma pētījuma grupās

Vecuma sadalījums abās grupās Šapiro-Vilka testā ir parametrisks (VLP grupai $\mathrm{p}=0,013$ un $\bar{A} F A$ grupai $\mathrm{p}=0,048)$. Grupu atškikīîas pēc vecuma tika pārbaudītas ar neatkarīgo izlašu $T$ testu, un tajā $p=0,355$, tātad grupas pēc vecuma statistiski neatškiras un ir līdzvērtīgas. Abās grupās lielākajai daḷai pacientu tika novēroti AO - C3 veida artikulārie lūzumi.

Pacientu sadalījums pēc vecuma, dzimuma, lūzuma klasifikācijas u. c. parametriem atainots 3.1. tabulā.

3.1. tabula

Pētāmo grupu raksturojums

\begin{tabular}{|l|c|c|c|}
\cline { 2 - 4 } \multicolumn{1}{c|}{} & VLP grupa & ĀFA grupa & P-vērtība \\
\hline Pacientu skaits & 34 & 30 & - \\
\hline Vīrieši / sievietes & $11 / 23$ & $13 / 17$ & 0,365 \\
\hline Vecums (gadi) & $52,4 \pm 14,7$ & $49,2 \pm 13,0$ & 0,355 \\
\hline Traumētā roka labā / kreisā & $9 / 25$ & $12 / 18$ & 0,250 \\
\hline Dominantā / nedominantā roka & $10 / 24$ & $10 / 20$ & - \\
\hline $\mathrm{AO}-\mathrm{C} 1$ & $11,8 \%$ & $6,7 \%$ & - \\
\hline $\mathrm{AO}-\mathrm{C} 2$ & $26,5 \%$ & $20,0 \%$ & - \\
\hline $\mathrm{AO}-\mathrm{C} 3$ & $58,8 \%$ & $73,3 \%$ & - \\
\hline Augstas enerğijas trauma & 3 & 5 & 0,334 \\
\hline Proc. styloideus ulnae lūzums & $41,1 \%$ & $56,7 \%$ & 0,443 \\
\hline Asociēto bojājumu skaits & $61,8 \%$ & $66,7 \%$ & 0,683 \\
\hline
\end{tabular}




\subsection{Pētījuma datu statistiskā apstrāde}

Abu pētāmo grupu pacientu populācijas dati, kā arī pētījuma mērījumos iegūtie dati sistematizēti Microsoft Excel datu apstrādes programmā. Klīnisko datu statistiskā apstrāde veikta, izmantojot datorprogrammu SPSS 20 (Statistical Package for the Social Sciences) prognozējošās analītikas un statistiskās analīzes programmatūras pakotne. Datu savstarpējā saistība meklēta ar neparametriskiem testiem un korelācijas analīzes metodēm. Visos gadījumos statistisko hipotēžu izvērtēšanai izmantots būtiskuma līmenis ( $\mathrm{p} \leq 0,05$ pieņemšanai un $\mathrm{p}>0,05$ noraidīšanai).

\subsection{Objektīvo mērījumu rezultāti}

Visos plaukstas locītavas kustību apjoma un satvēriena spēka mērījumos uzrādīts kustību apjoms vai spēks (\%), salīdzinot ar veselo roku 1., 3., 6., un 12. mēnesī pēc operācijas. Tā kā nebija iespējams pierādīt, ka iegūtie mērījumu rezultāti atbilst normālajam sadalījumam (tas arī būs redzams pēc histogrammām), rezultātu apkopošanai un izvērtēšanai tika lietoti tikai neparametriskie testi (Mann-Whitney un Kolmogorova-Smirnova testi, lai analizētu mērījumu rezultātu atšķirīibas starp kontrolgrupām, un Wilcoxon Signed Ranks un Sign testi, lai parādītu mērījumu rezultātu izmaiņas atkarībā no pagājušo mēnešu skaita kopš operācijas).

\subsubsection{Plaukstas fleksija}

Lietojot standarta statistiskas metodologiju plaukstas fleksijas vidējās vērtības noteikšanai atkarībā no manipulācijas veida un pagājušā laika intervāla pēc operācijas, ieguvām vidējo vērtību rādījumus (95 \% ticamības intervālus) (sk. 3.2. tabulu, 3.3. attēlu).

3.2. tabula

\section{Plaukstas fleksijas vidējās vērtības}

\begin{tabular}{|l|c|c|c|c|}
\cline { 2 - 5 } \multicolumn{1}{c|}{} & 1. mēn. & 3. mēn. & 6. mēn. & 12. mēn. \\
\hline VLP grupa, \% & $40,7 \pm 5,6$ & $62,3 \pm 4,9$ & $77,3 \pm 5,3$ & $84,7 \pm 4,6$ \\
\hline ĀFA grupa, \% & $32,9 \pm 4,3$ & $63,6 \pm 6,7$ & $77,1 \pm 5,0$ & $81,3 \pm 5,5$ \\
\hline
\end{tabular}

Aprēḳina pēc formulas Mean \pm (Mean Upper Bound - Mean Lower Bound) / 2. 


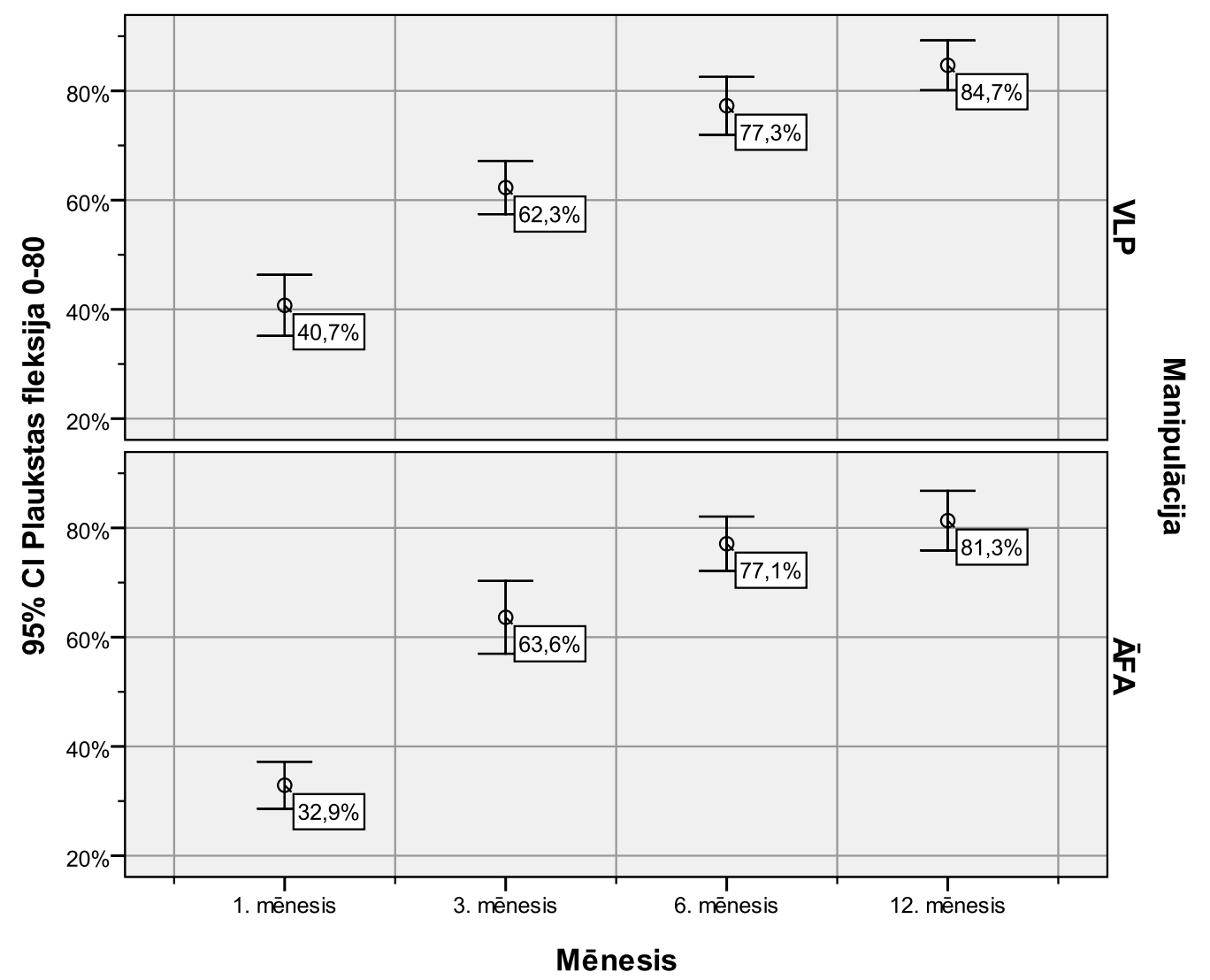

3.3. attēls. Plaukstas fleksijas vērtības atkarībā no manipulācijas veida un pagājušā laika intervāla pēc operācijas

Plaukstas fleksijas mērījumu atkarību no manipulācijas veida un tā dinamikas atkarībā no laika intervāla pēc operācijas vizuāli vēl pilnīgāk var novērtēt pēc histogrammām (sk. 3.4 A, B, C un D attēlu). 

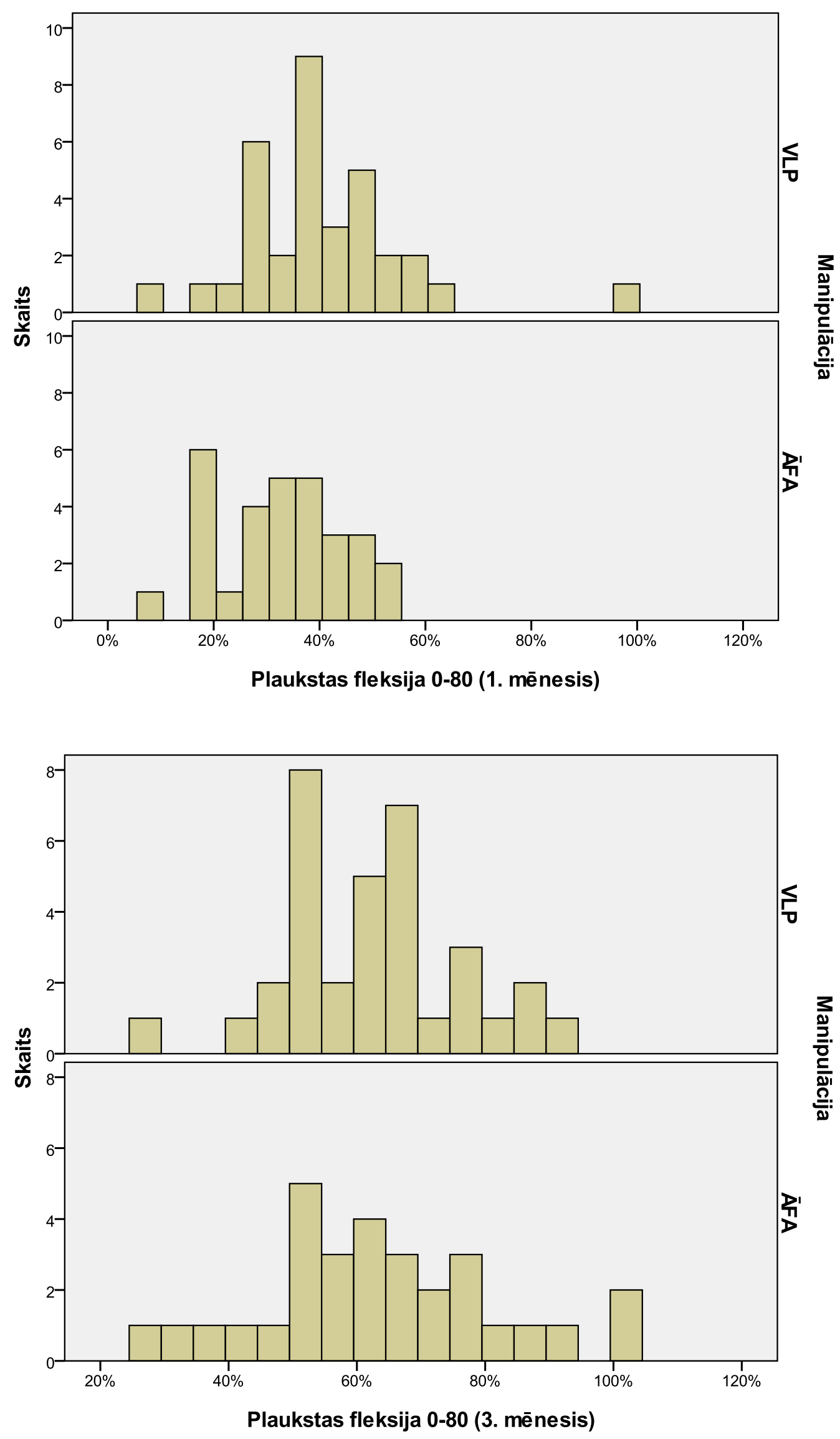

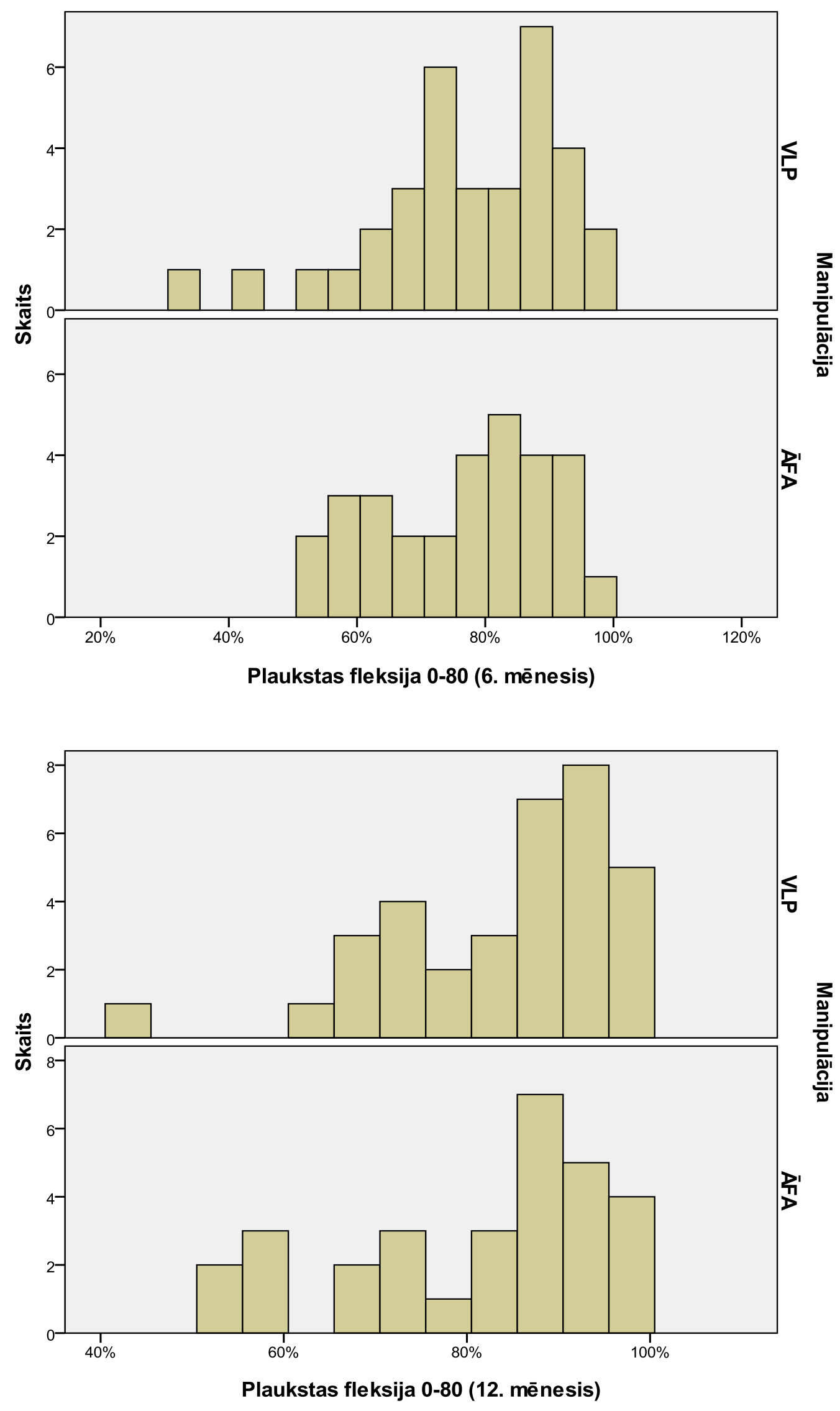

3.4. A, B, C, D attēls. Plaukstas fleksijas rezultāti dinamikā 
Lai analizētu, vai plaukstas fleksijas mērījumi statistiski būtiski atšķiras starp kontrolgrupām atkarībā no mēnešu skaita kopš operācijas, tika lietoti Mann-Whitney un Kolmogorova-Smirnova testi. Iegūti šādi rezultāti - statistiski būtiskas atšḳirības plaukstas fleksijas parametra vērtībās atkarībā no manipulācijas veida ir tikai 1 . mēnesī $(p<0,05)$ pēc operācijas (sk. 3.3. tabulu).

3.3. tabula

Atšḳirības plaukstas fleksijas parametra vērtībās atkarībā no manipulācijas veida

\begin{tabular}{|l|c|c|c|c|}
\cline { 2 - 5 } \multicolumn{1}{c|}{} & $\mathbf{1 .}$ mēn. & 3. mēn. & 6. mēn. & 12. mēn. \\
\hline $\begin{array}{l}\text { Ir statistiski būtiskas atšķirības starp VLP } \\
\text { un ĀFA grupu }\end{array}$ & $\mathrm{jā}$ & $\mathrm{ne}$ & $\mathrm{n} \overline{\mathrm{e}}$ & $\mathrm{ne}$ \\
\hline p-vērtība (Mann-Whitney tests) & $\mathbf{0 , 0 4 8}$ & 0,731 & 0,819 & 0,325 \\
\hline p-vērtība (Kolmogorova-Smirnova tests) & 0,303 & 0,995 & 0,999 & 0,717 \\
\hline
\end{tabular}

P-vērtības sakrīt ar Asymp. Sig. (2-tailed) aprēḳinu materiālos. Ja kolonnā kaut viena p-vērtība mazāka vai vienāda ar 0,05 , raksta "jā̄", pretējā gadījumā "nē".

Lai noskaidrotu, vai plaukstas fleksijas mērījumi statistiski būtiski uzlabojas, ritot laikam pēc operācijas, tiek lietoti Wilcoxon Signed Ranks un Sign testi. Tika iegūti šādi rezultāti - abi testi rāda statistiski būtisku, monotonu plaukstas fleksijas parametra uzlabojumu, ritot laikam pēc operācijas abās pētījumu grupās $(\mathrm{p}<0,01)$ (sk. 3.4. tabulu).

3.4. tabula

Plaukstas fleksijas mērījumi, lietojot Wilcoxon Signed Ranks un Sign testus

\begin{tabular}{|c|c|c|c|}
\hline & $\begin{array}{l}\text { 3. mēn. } \\
\text { pret 1. mēn. }\end{array}$ & $\begin{array}{l}\text { 6. mēn. } \\
\text { pret 3. mēn. }\end{array}$ & $\begin{array}{l}\text { 12. mēn. } \\
\text { pret 6. mēn. }\end{array}$ \\
\hline $\begin{array}{l}\text { Ir statistiski būtisks uzlabojums } \\
\text { (VLP grupa) }\end{array}$ & jā & $\mathrm{ja} \overline{\mathrm{a}}$ & $\mathrm{ja}$ \\
\hline $\begin{array}{l}\text { Ir statistiski būtisks uzlabojums } \\
\text { (ĀFA grupa) }\end{array}$ & jā & jā & jā \\
\hline $\begin{array}{l}\text { p-vērtība (Wilcoxon Signed Ranks } \\
\text { tests) VLP grupai }\end{array}$ & 0,000 & $\mathbf{0 , 0 0 0}$ & $\mathbf{0 , 0 0 0}$ \\
\hline p-vērtība (Sign tests) VLP grupai & $\mathbf{0 , 0 0 0}$ & $\mathbf{0 , 0 0 0}$ & $\mathbf{0 , 0 0 1}$ \\
\hline $\begin{array}{l}\text { p-vērtība (Wilcoxon Signed Ranks } \\
\text { tests) ĀFA grupai }\end{array}$ & 0,000 & $\mathbf{0 , 0 0 0}$ & 0,001 \\
\hline p-vērtība (Sign tests) ĀFA grupai & $\mathbf{0 , 0 0 0}$ & $\mathbf{0 , 0 0 0}$ & $\mathbf{0 , 0 0 3}$ \\
\hline
\end{tabular}

P-vērtības sakrīt ar Asymp. Sig. (2-tailed) / 2 aprēḳinu materiālos. Ja kolonnā kaut viena p-vērtība mazāka vai vienāda ar 0,05 , raksta "jā̄, pretējā gadījumā "nē".

\subsubsection{Plaukstas ekstensija}

Lietojot standarta statistiskas metodolog̣iju plaukstas ekstensijas vidējās vērtības noteikšanai atkarībā no manipulācijas veida un pagājušā laika intervāla pēc operācijas, ieguvām šādas vidējās vērtības (95 \% ticamības intervālus) (sk. 3.5. tabulu, 3.5. attēlu). 
Vidējās vērtības plaukstas ekstensijas noteikšanai

\begin{tabular}{|l|c|c|c|c|}
\cline { 2 - 5 } \multicolumn{1}{c|}{} & 1. mēn. & 3. mēn. & 6. mēn. & 12. mēn. \\
\hline VLP grupa, \% & $46,2 \pm 6,7$ & $72,9 \pm 5,5$ & $87,6 \pm 4,0$ & $91,9 \pm 3,7$ \\
\hline ĀFA grupa, \% & $20,1 \pm 6,1$ & $72,8 \pm 7,5$ & $80,9 \pm 5,6$ & $88,9 \pm 4,4$ \\
\hline
\end{tabular}

Aprēḳina pēc formulas Mean \pm (Mean Upper Bound-Mean Lower Bound) / 2.

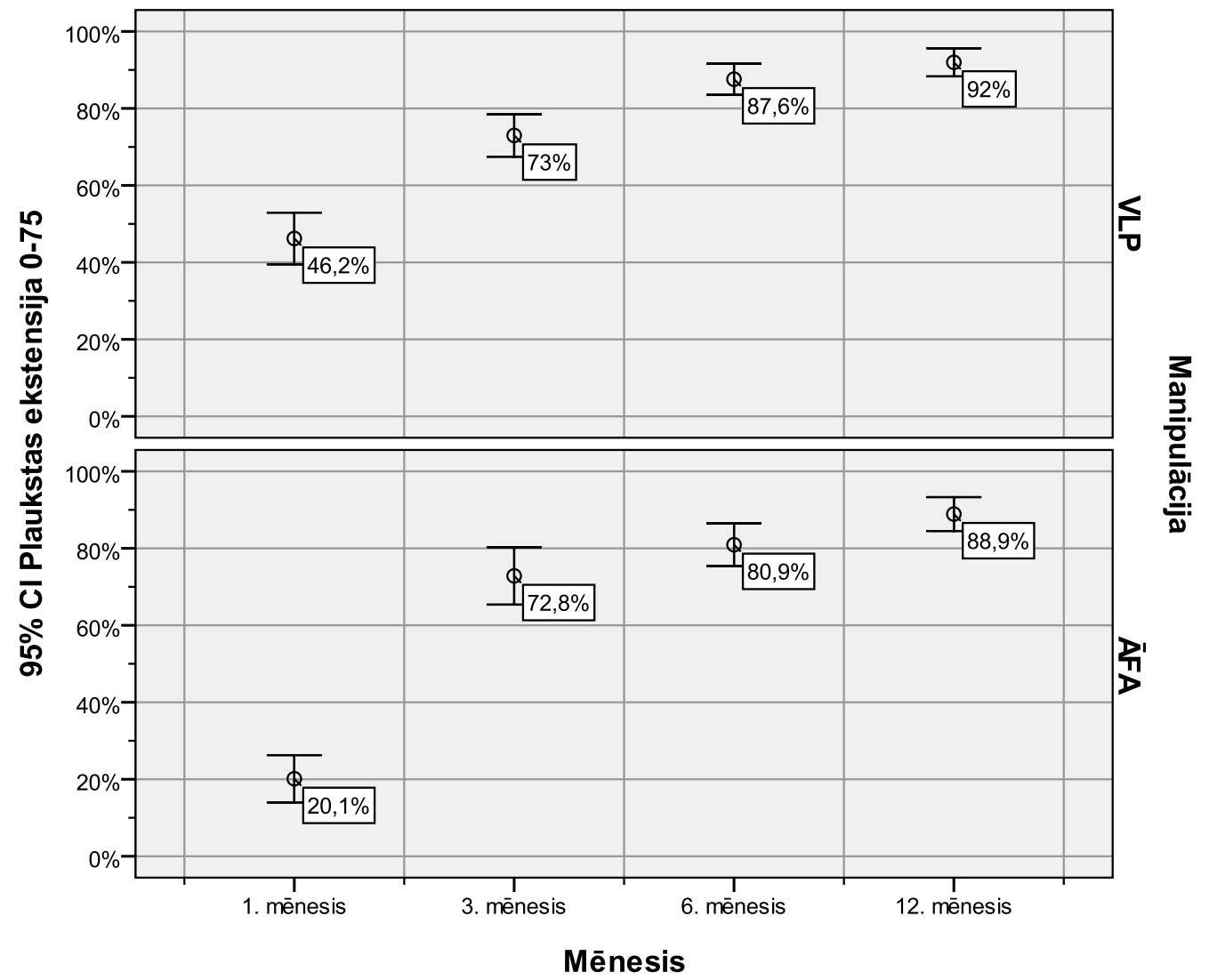

3.5. attēls. Plaukstas ekstensijas vērtības atkarībā no manipulācijas veida un pagājušā laika intervāla pēc operācijas

Plaukstas ekstensijas mērījumu atkarību no manipulācijas veida un tā dinamiku atkarībā no laika intervāla pēc operācijas vizuāli vēl pilnīgāk var novērtêt pēc histogrammām (sk. 3.6. A, B, C un D attēlu). 


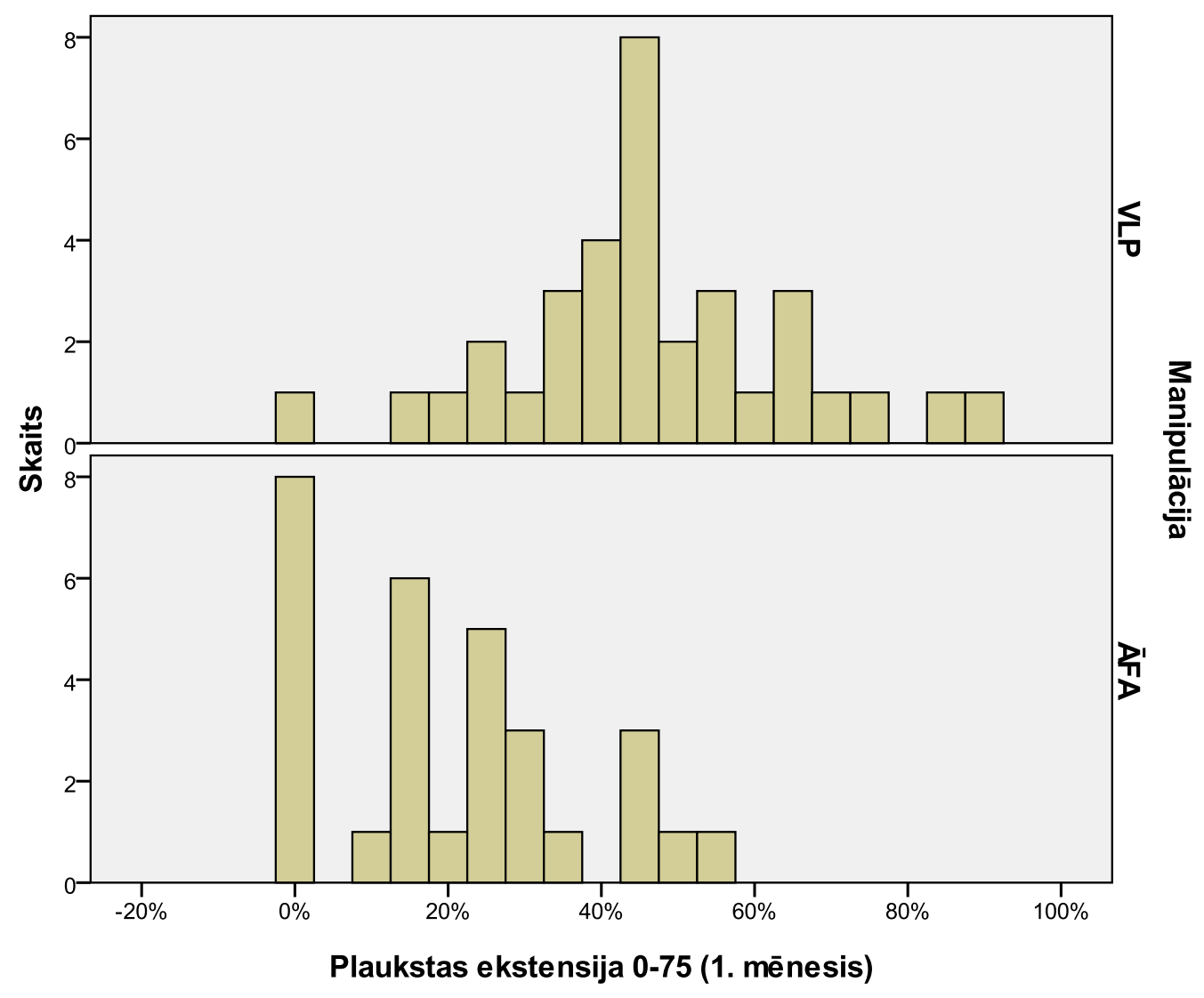

A

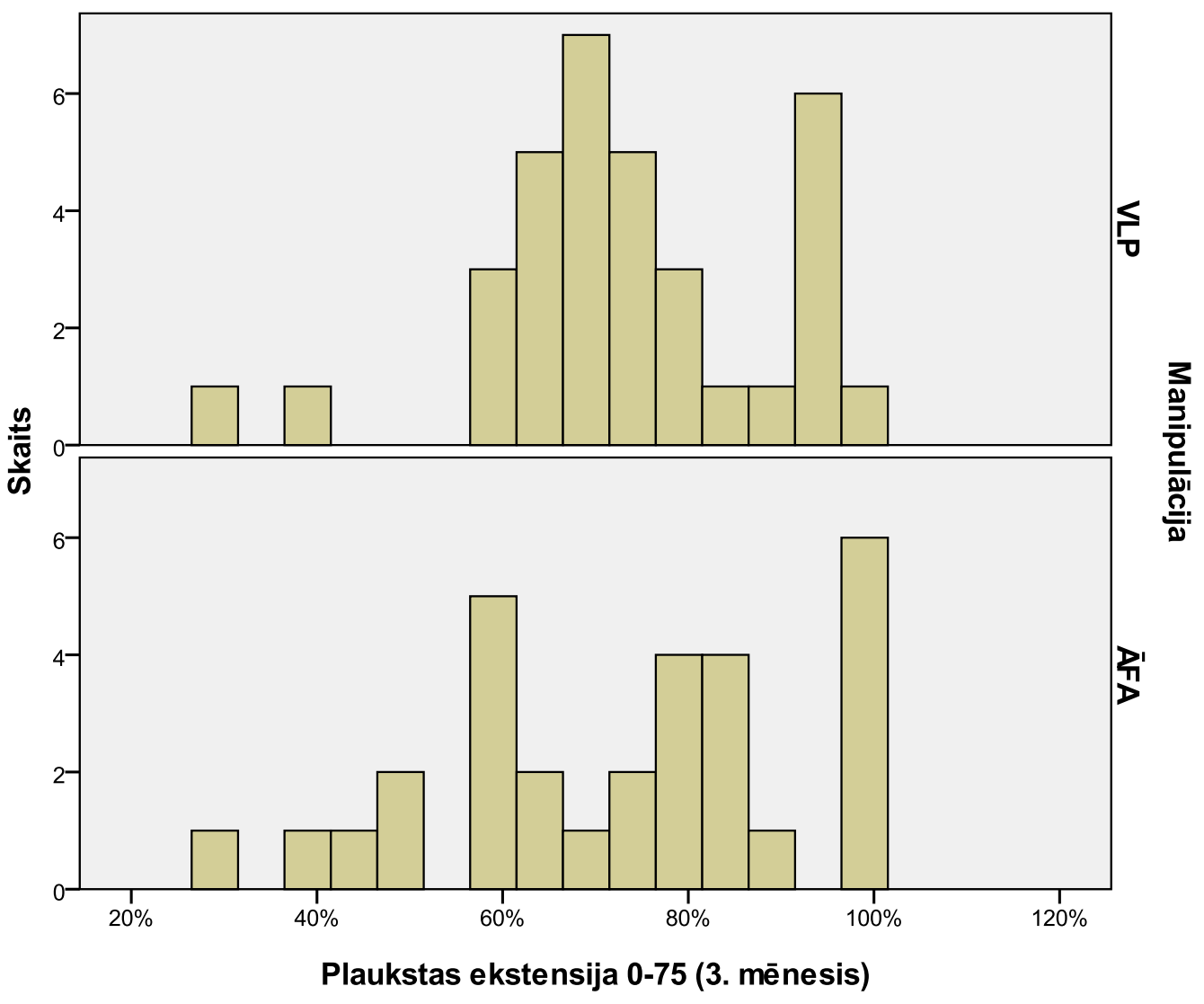




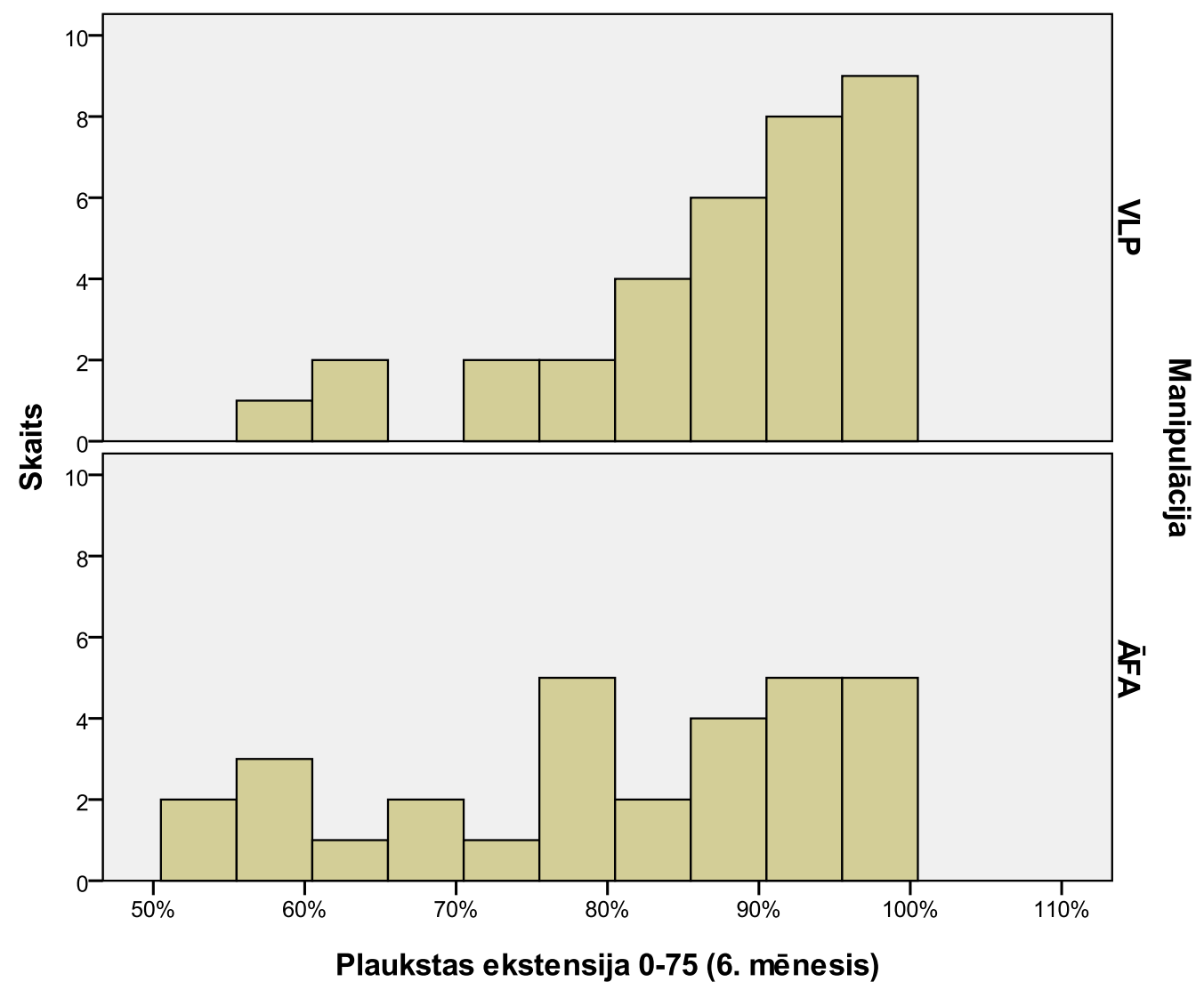

C

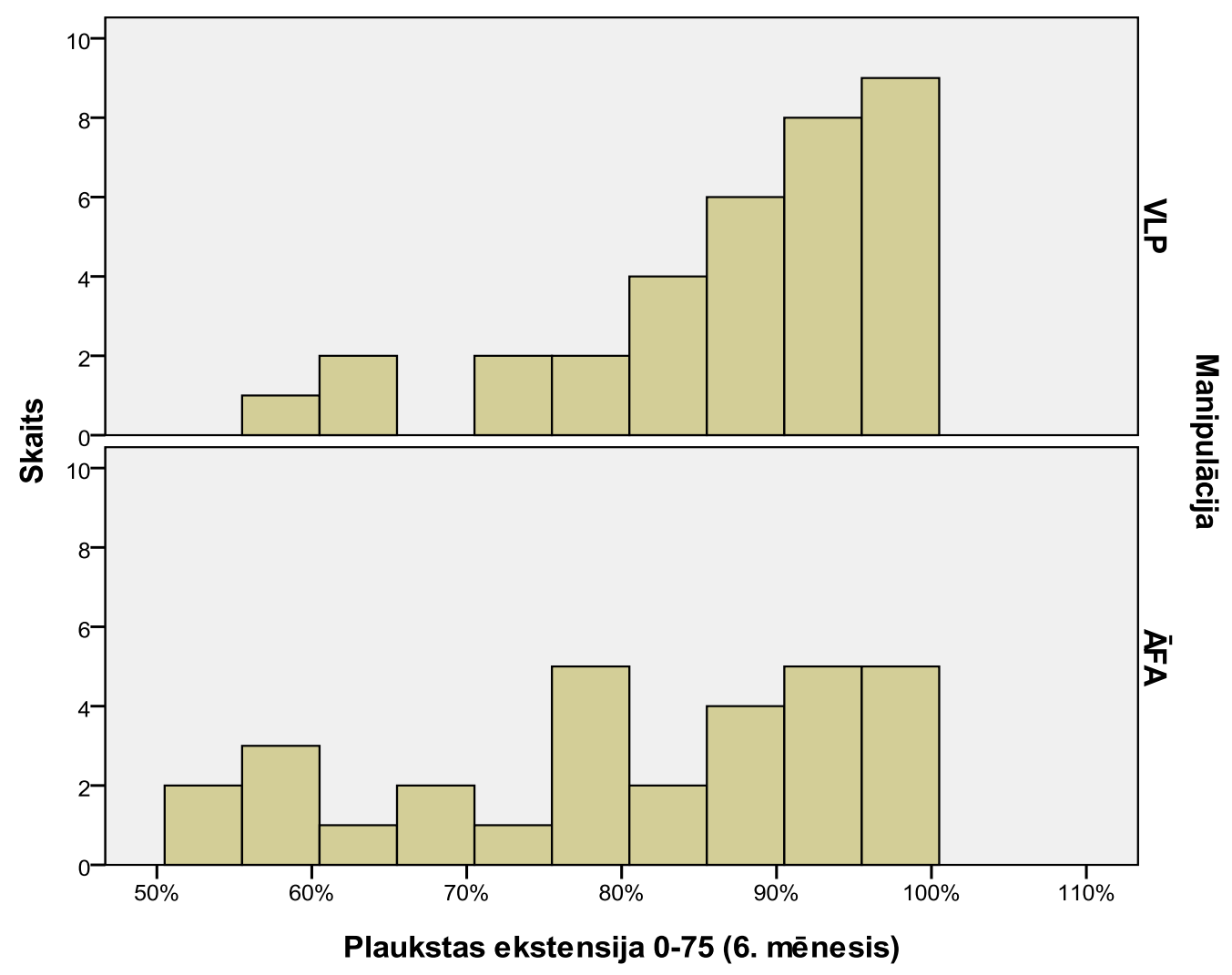

3.6. A, B, C, D attēls. Plaukstas ekstensijas rezultāti dinamikā 
Lai analizētu, vai plaukstas ekstensijas mērījumi statistiski būtiski atšķiras starp kontrolgrupām atkarībā no mēnešu skaita kopš operācijas, tika lietoti Mann-Whitney un Kolmogorova-Smirnova testi. Iegūti šādi rezultāti - statistiski būtiskas atšḳirības plaukstas ekstensijas parametra vērtībās atkarībā no manipulācijas veida ir tikai 1 . mēnes̄i $(p<0,05)$ pēc operācijas (sk. 3.6. tabulu).

\section{6. tabula}

\section{Plaukstas ekstensijas mērījumi, lietojot Mann-Whitney un Kolmogorova-Smirnova testus}

\begin{tabular}{|c|c|c|c|c|}
\hline & 1. mēn. & 3. mēn. & 6. mēn. & 12. mēn. \\
\hline $\begin{array}{l}\text { Ir statistiski būtiskas atšḳirīibas starp } \\
\text { VLP un ĀFA grupu }\end{array}$ & jā & $\mathrm{ne \overline { }}$ & $\mathrm{ne \overline { }}$ & $\mathrm{ne \overline { }}$ \\
\hline p-vērtība (Mann-Whitney tests) & 0,000 & 0,995 & 0,056 & 0,324 \\
\hline p-vērtība (Kolmogorova-Smirnova tests) & $\mathbf{0 , 0 0 0}$ & 0,472 & 0,181 & 0,403 \\
\hline
\end{tabular}

P-vērtības sakrīt ar Asymp. Sig. (2-tailed) aprēkinu materiālos. Ja kolonnā kaut viena p-vērtība mazāka vai vienāda ar 0,05 , raksta "jā", pretējā gadījumā "nē".

Lai noskaidrotu, vai plaukstas ekstensijas mērījumi statistiski būtiski uzlabojas, ritot laikam pēc operācijas, tiek lietoti Wilcoxon Signed Ranks un Sign testi. Iegūti šādi rezultāti abi testi rāda statistiski būtisku, monotonu plaukstas ekstensijas parametra uzlabojumu, ritot laikam pēc operācijas abās pētījumu grupās (p < 0,01) (sk. 3.7. tabulu).

3.7. tabula

Plaukstas ekstensijas mērījumi, lietojot Wilcoxon Signed Ranks un Sign testus

\begin{tabular}{|c|c|c|c|}
\hline & $\begin{array}{l}\text { 3. mēn. pret } \\
\text { 1. mēn. }\end{array}$ & $\begin{array}{l}\text { 6. mēn. pret } \\
\text { 3. mēn. }\end{array}$ & $\begin{array}{l}\text { 12. mēn. } \\
\text { pret } 6 . \text { mēn. }\end{array}$ \\
\hline $\begin{array}{l}\text { Ir statistiski būtisks uzlabojums } \\
\text { (VLP grupa) }\end{array}$ & jā & jā & jā \\
\hline $\begin{array}{l}\text { Ir statistiski būtisks uzlabojums } \\
\text { (ĀFA grupa) }\end{array}$ & jā & $\mathrm{ja}$ & jā \\
\hline $\begin{array}{l}\text { p-vērtība (Wilcoxon Signed Ranks } \\
\text { tests) VLP grupai }\end{array}$ & $\mathbf{0 , 0 0 0}$ & $\mathbf{0 , 0 0 0}$ & $\mathbf{0 , 0 0 3}$ \\
\hline p-vērtība (Sign tests) VLP grupai & $\mathbf{0 , 0 0 0}$ & $\mathbf{0 , 0 0 0}$ & $\mathbf{0 , 0 8 9}$ \\
\hline $\begin{array}{l}\text { p-vērtība (Wilcoxon Signed Ranks } \\
\text { tests) ĀFA grupai }\end{array}$ & $\mathbf{0 , 0 0 0}$ & 0,005 & 0,000 \\
\hline p-vērtība (Sign tests) ĀFA grupai & 0,000 & $\mathbf{0 , 0 0 7}$ & $\mathbf{0 , 0 0 0}$ \\
\hline
\end{tabular}

P-vērtības sakrīt ar Asymp. Sig. (2-tailed) / 2 aprēḳinu materiālos. Ja kolonnā kaut viena p-vērtība mazāka vai vienāda ar 0,05 , raksta "jā̄", pretējā gadījumā "nē".

\subsubsection{Plaukstas radiālā deviācija}

Lietojot standarta statistiskas metodologiju plaukstas radiālās deviācijas vidējās vērtības noteikšanai atkarībā no manipulācijas veida un pagājušā laika intervāla pēc operācijas, ieguvām šādas vidējās vērtības (95 \% ticamības intervāli) (sk. 3.8. tabulu, 3.7. attēlu). 
Plaukstas radiālās deviācijas vidējās vērtības

\begin{tabular}{|l|c|c|c|c|}
\cline { 2 - 5 } \multicolumn{1}{c|}{} & 1. mēn. & 3. mēn. & 6. mēn. & 12. mēn. \\
\hline VLP grupa, \% & $41,5 \pm 8,3$ & $74,5 \pm 5,6$ & $84,3 \pm 5,6$ & $89,9 \pm 3,7$ \\
\hline ĀFA grupa, \% & $26,0 \pm 7,9$ & $61,7 \pm 8,9$ & $72,9 \pm 5,5$ & $80,6 \pm 6,3$ \\
\hline
\end{tabular}

Aprēķina pēc formulas Mean \pm (Mean Upper Bound - Mean Lower Bound) / 2

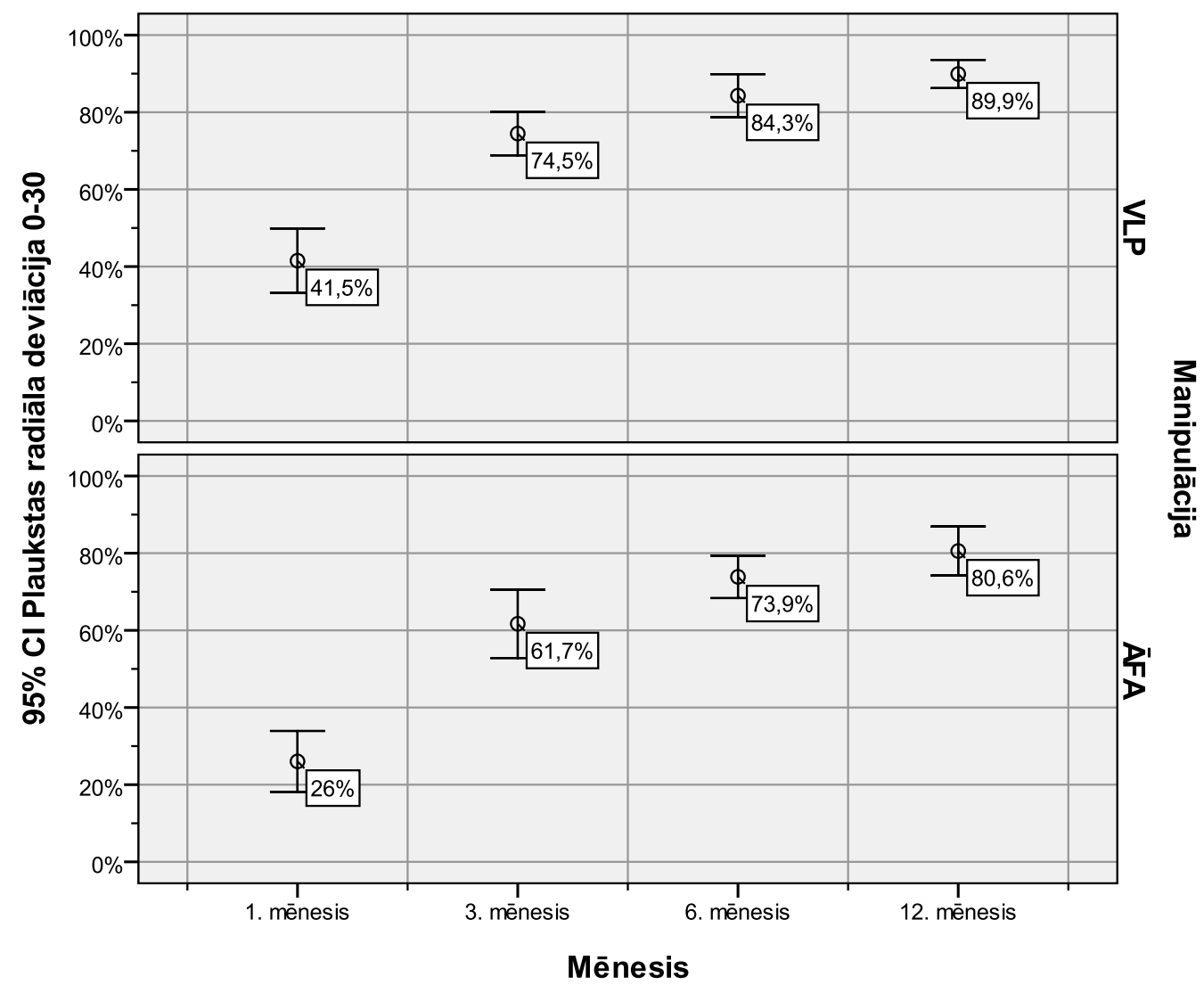

3.7. attēls. Plaukstas radiālās deviācijas vērtības atkarībā no manipulācijas veida un pagājušā laika intervāla pēc operācijas

Plaukstas radiālās deviācijas mērījumu atkarību no manipulācijas veida un tā dinamiku atkarībā no laika intervāla pēc operācijas vizuāli vēl pilnīgāk var novērtēt pēc histogrammām (sk. 3.8. A, B, C un D attēlu). 


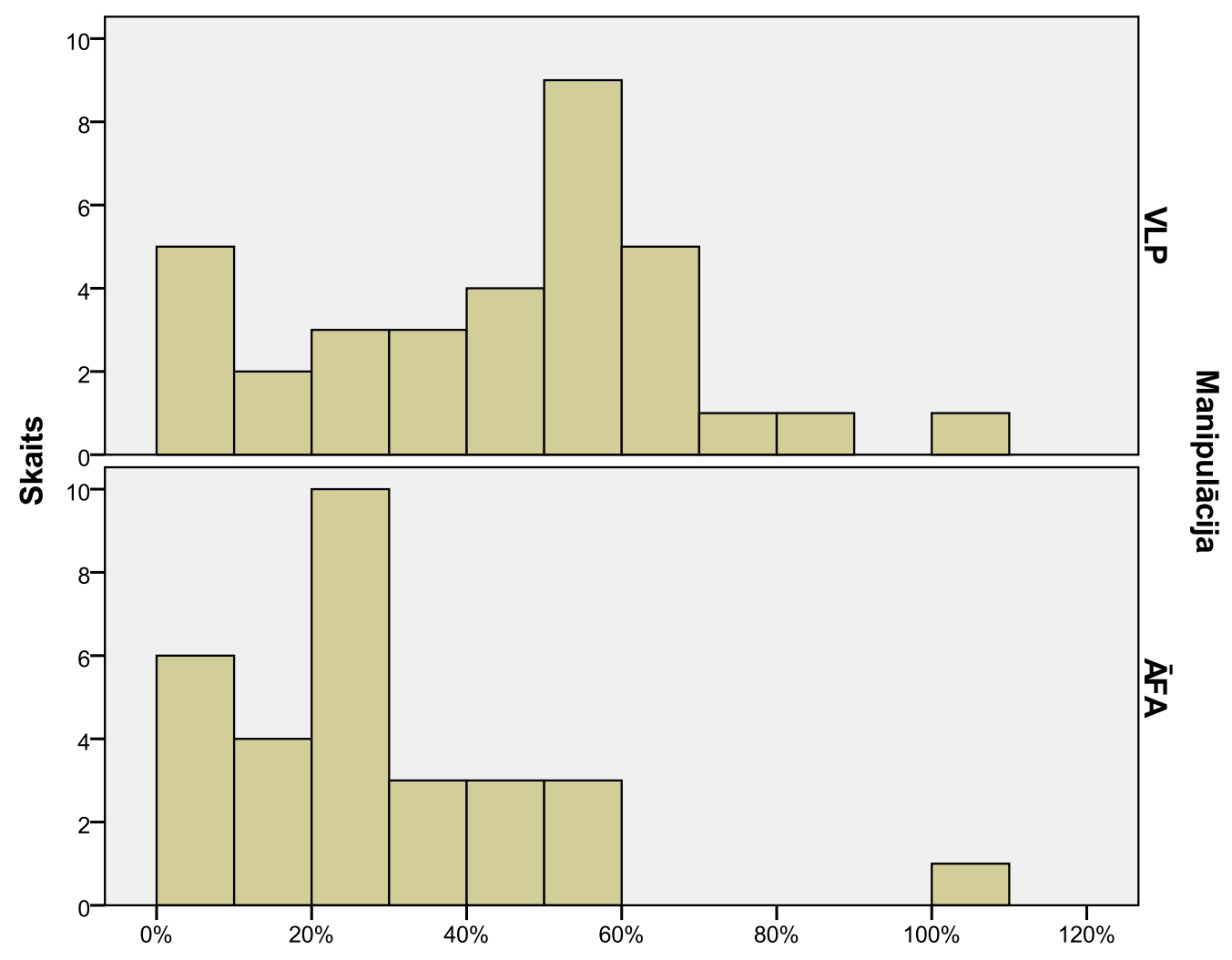

A

Plaukstas radiāla deviācija 0-30 (1. mēnesis)

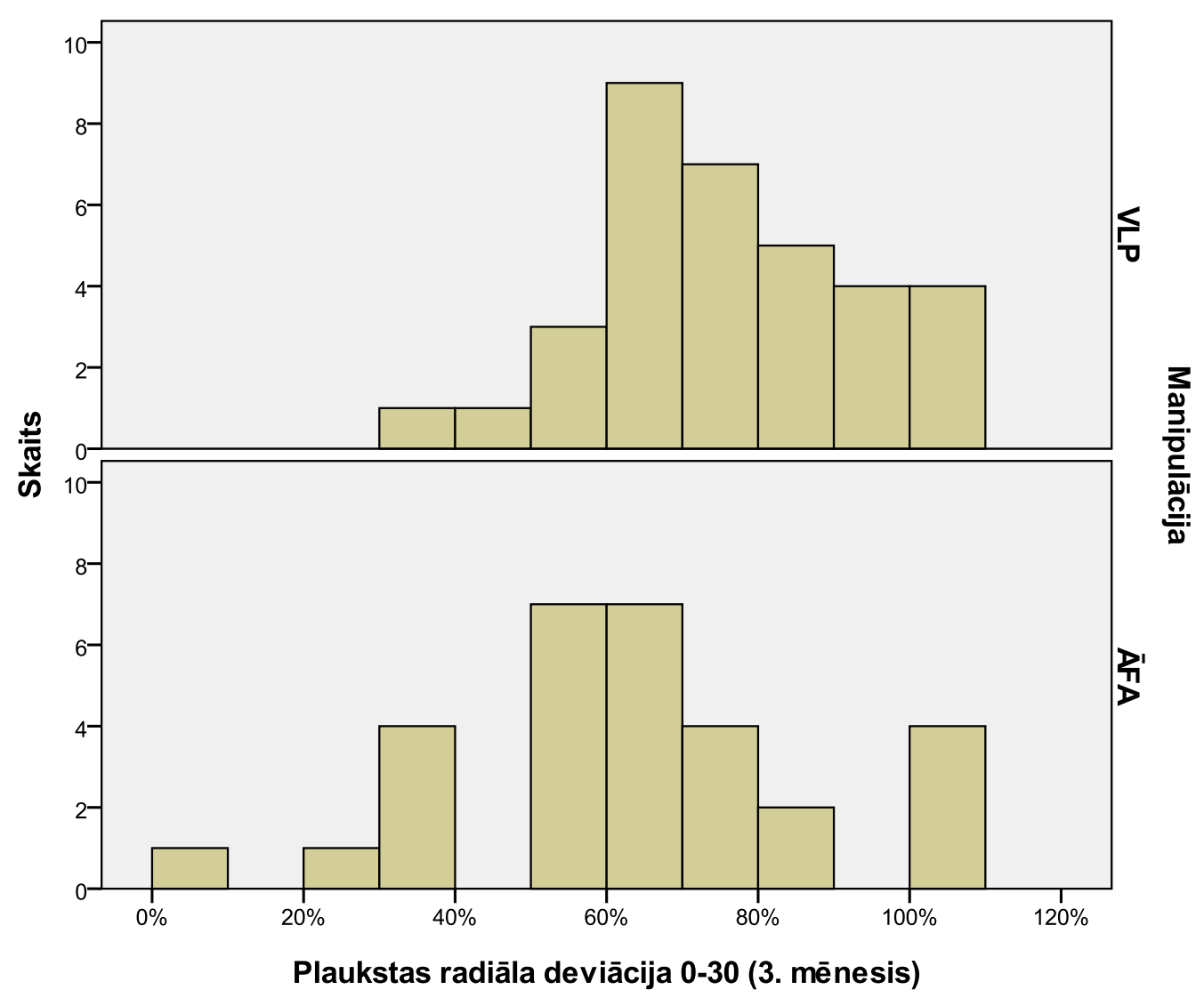




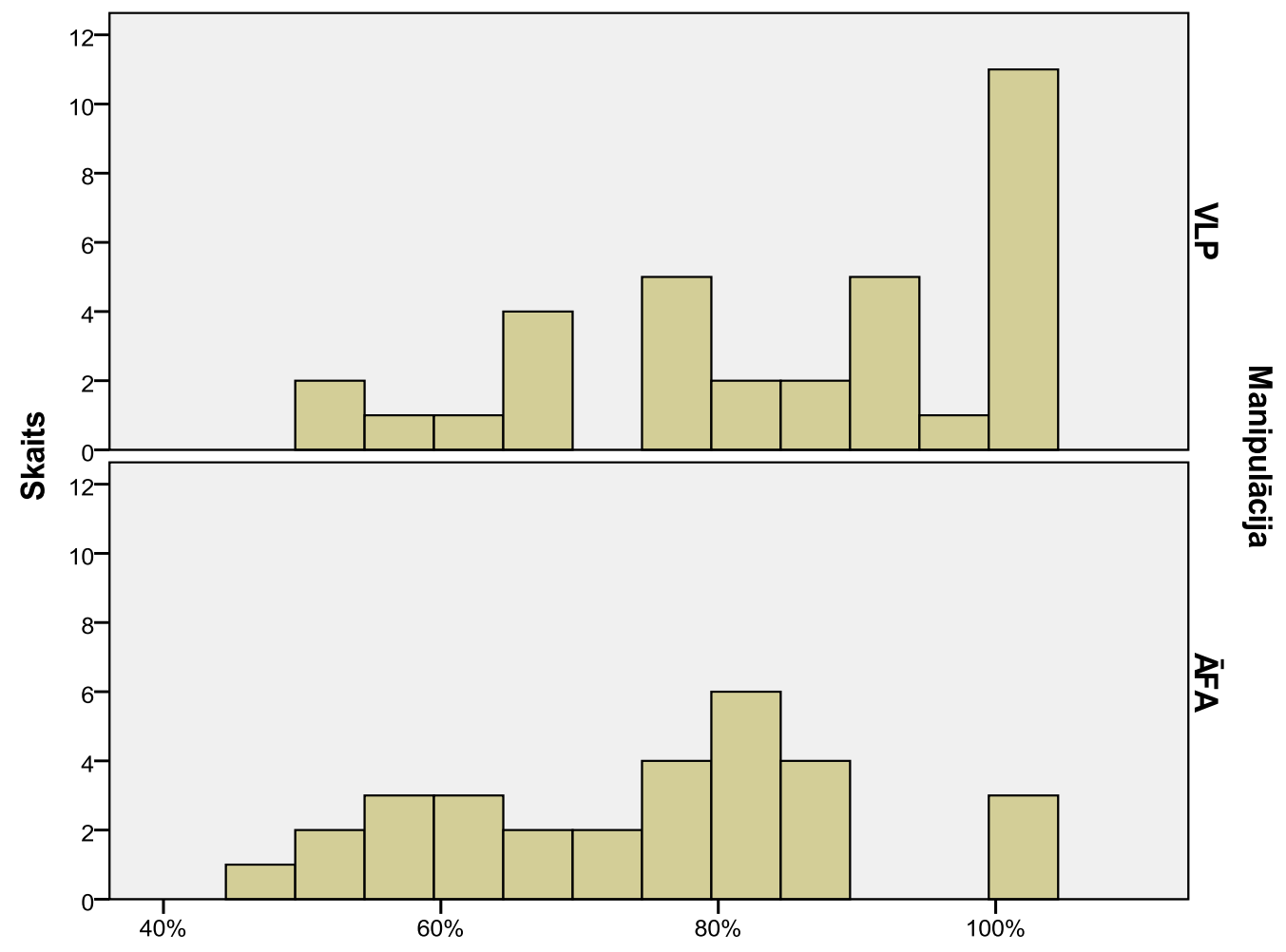

C

Plaukstas radiāla deviācija 0-30 (6. mēnesis)

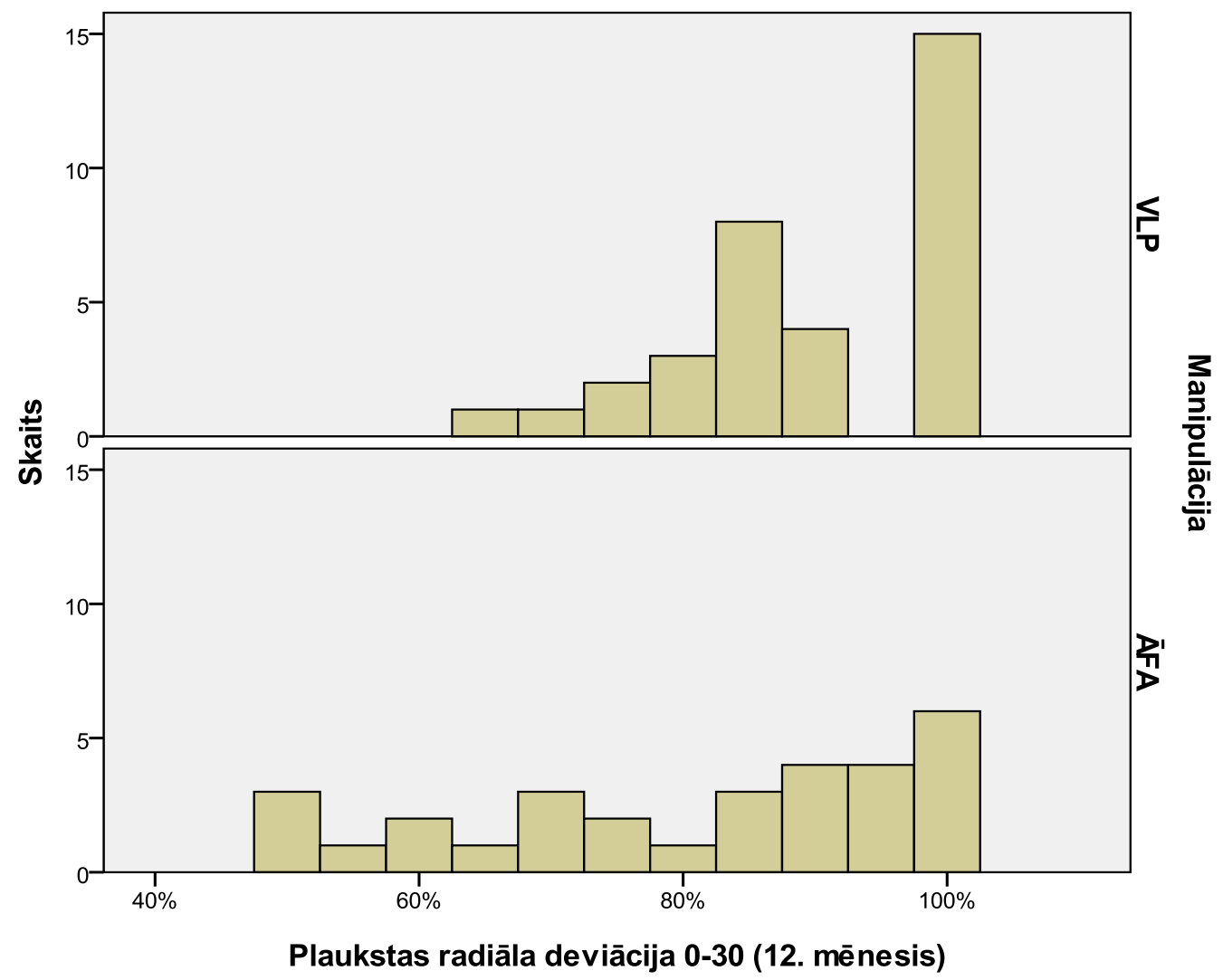

3.8. A, B, C, D attēls. Plaukstas radiālās deviācijas rezultāti dinamikā 
Lai analizētu, vai plaukstas radiālās deviācijas mērījumi statistiski būtiski atšķiras starp kontrolgrupām atkarībā no mēnešu skaita kopš operācijas, tika lietoti Mann-Whitney un Kolmogorova-Smirnova testi. Iegūti šādi rezultāti - statistiski būtiskas atšḳirības plaukstas radiālās deviācijas parametra vērtībās atkarībā no manipulācijas veida ir visos mērījumos (p < 0,05) pēc operācijas (sk. 3.9. tabulu).

3.9. tabula

\section{Plaukstas radiālās deviācijas mērījumi, lietojot Mann-Whitney un Kolmogorova-Smirnova testus}

\begin{tabular}{|l|c|c|c|c|}
\cline { 2 - 5 } \multicolumn{1}{c|}{} & $\mathbf{1 .}$ mēn. & 3. mēn. & 6. mēn. & 12. mēn. \\
\hline Ir statistiski būtiskas atšķirības starp & jā & jā & $j \bar{a}$ & jā \\
\hline VLP un ĀFA grupu & $\mathbf{0 , 0 0 3}$ & $\mathbf{0 , 0 1 4}$ & $\mathbf{0 , 0 0 9}$ & $\mathbf{0 , 0 3 6}$ \\
\hline p-vērtība (Mann-Whitney tests) & $\mathbf{0 , 0 1 2}$ & 0,071 & $\mathbf{0 , 0 1 2}$ & 0,098 \\
\hline p-vērtība (Kolmogorova-Smirnova tests)
\end{tabular}

P-vērtības sakrīt ar Asymp. Sig. (2-tailed) aprēḳinu materiālos. Ja kolonnā kaut viena p-vērtība mazāka vai vienāda ar 0,05 , raksta "jā̄", pretējā gadījumā "nē".

Lai noskaidrotu, vai plaukstas radiālās deviācijas mērījumi statistiski būtiski uzlabojas, ritot laikam pēc operācijas, tiek lietoti Wilcoxon Signed Ranks un Sign testi. Iegūti šādi rezultāti - abi testi rāda statistiski būtisku, monotonu plaukstas radiālās deviācijas parametra uzlabojumu, ritot laikam pēc operācijas abās pētījumu grupās (p < 0,01) (sk. 3.10. tabulu).

3.10. tabula

Plaukstas radiālās deviācijas mērījumi, lietojot Wilcoxon Signed Ranks un Sign testus

\begin{tabular}{|c|c|c|c|}
\hline & $\begin{array}{c}\text { 3. mēn. } \\
\text { pret } 1 . \text { mēn. }\end{array}$ & $\begin{array}{l}\text { 6. mēn } \\
\text { pret 3. mēn. }\end{array}$ & $\begin{array}{l}\text { 12. mēn } \\
\text { pret 6. mēn. }\end{array}$ \\
\hline $\begin{array}{l}\text { Ir statistiski būtisks uzlabojums } \\
\text { (VLP grupa) }\end{array}$ & jā & jā & jā \\
\hline $\begin{array}{l}\text { Ir statistiski būtisks uzlabojums } \\
\text { (ĀFA grupa) }\end{array}$ & $\mathrm{jā}$ & jā & $\mathrm{ja}$ \\
\hline $\begin{array}{l}\text { p-vērtība (Wilcoxon Signed Ranks } \\
\text { tests) VLP grupai }\end{array}$ & $\mathbf{0 , 0 0 0}$ & 0,001 & 0,058 \\
\hline p-vērtība (Sign tests) VLP grupai & $\mathbf{0 , 0 0 0}$ & $\mathbf{0 , 0 0 1}$ & $\mathbf{0 , 0 4 3}$ \\
\hline $\begin{array}{l}\text { p-vērtība (Wilcoxon Signed Ranks } \\
\text { tests) ĀFA grupai }\end{array}$ & $\mathbf{0 , 0 0 0}$ & $\mathbf{0 , 0 0 3}$ & $\mathbf{0 , 0 3 8}$ \\
\hline p-vērtība (Sign tests) ĀFA grupai & $\mathbf{0 , 0 0 0}$ & $\mathbf{0 , 0 1 1}$ & $\mathbf{0 , 0 2 1}$ \\
\hline
\end{tabular}

P-vērtības sakrīt ar Asymp. Sig. (2-tailed) / 2 aprēķinu materiālos. Ja kolonnā kaut viena p-vērtība mazāka vai vienāda ar 0,05 , raksta "jā", pretējā gadījumā "nē". 


\subsubsection{Plaukstas ulnārā deviācija}

Lietojot standarta statistiskas metodoloǵiju plaukstas ulnārās deviācijas vidējās vērtības noteikšanai atkarībā no manipulācijas veida un pagājušā laika intervāla pēc operācijas, ieguvām šādas vidējās vērtības (95 \% ticamības intervālus) (sk. 3.11. tabulu).

3.11. tabula

Plaukstas ulnārās deviācijas vidējās vērtības

\begin{tabular}{|l|c|c|c|c|}
\cline { 2 - 5 } \multicolumn{1}{c|}{} & 1. mēn. & 3. mēn. & 6. mēn. & 12. mēn. \\
\hline VLP grupa, \% & $41,8 \pm 8,9$ & $70,1 \pm 6,3$ & $79,9 \pm 5,5$ & $87,8 \pm 3,7$ \\
\hline ĀFA grupa, \% & $38,5 \pm 8,7$ & $64,9 \pm 8,1$ & $78,3 \pm 6,4$ & $88,0 \pm 5,0$ \\
\hline
\end{tabular}

Aprēḳina pēc formulas Mean \pm (Mean Upper Bound - Mean Lower Bound) / 2.

Mērījumu rezultātu vizualizācija skatāma 3.9. un 3.10. A, B, C, D attēlā.

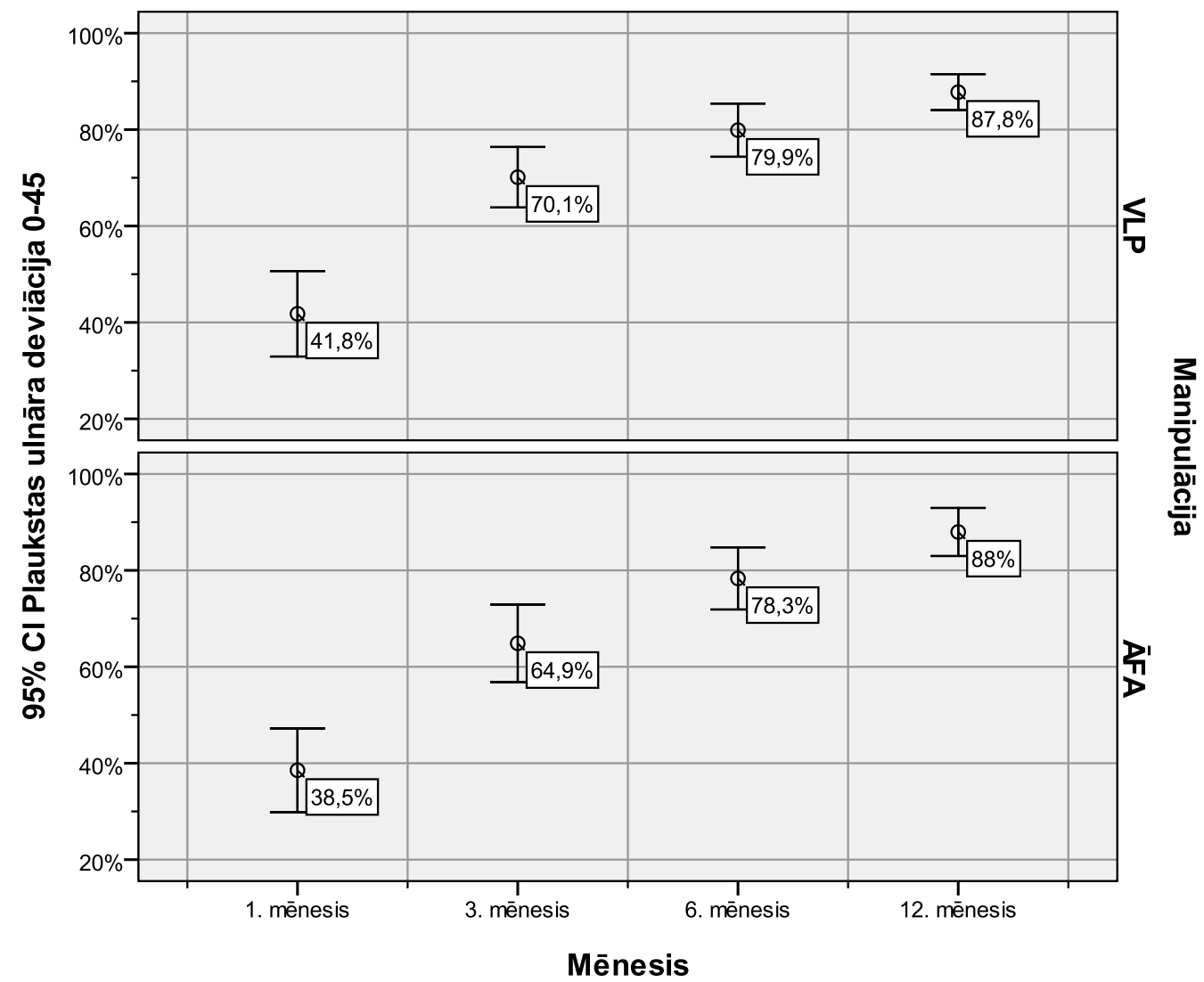

3.9. attēls. Plaukstas ulnārās deviācijas vērtības atkarībā no manipulācijas veida un pagājušā laika intervāla pēc operācijas 


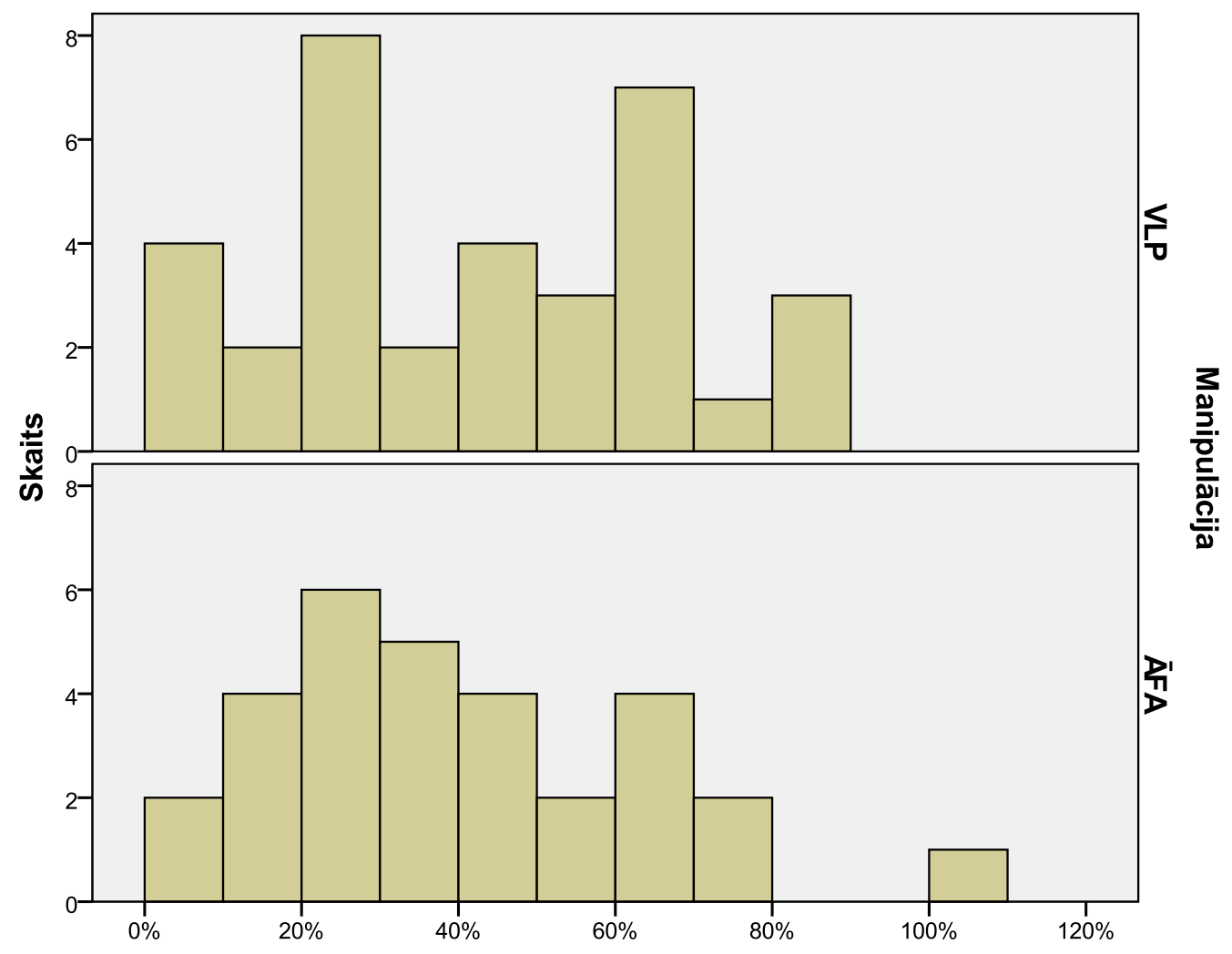

A

Plaukstas ulnāra deviācija 0-45 (1. mēnesis)

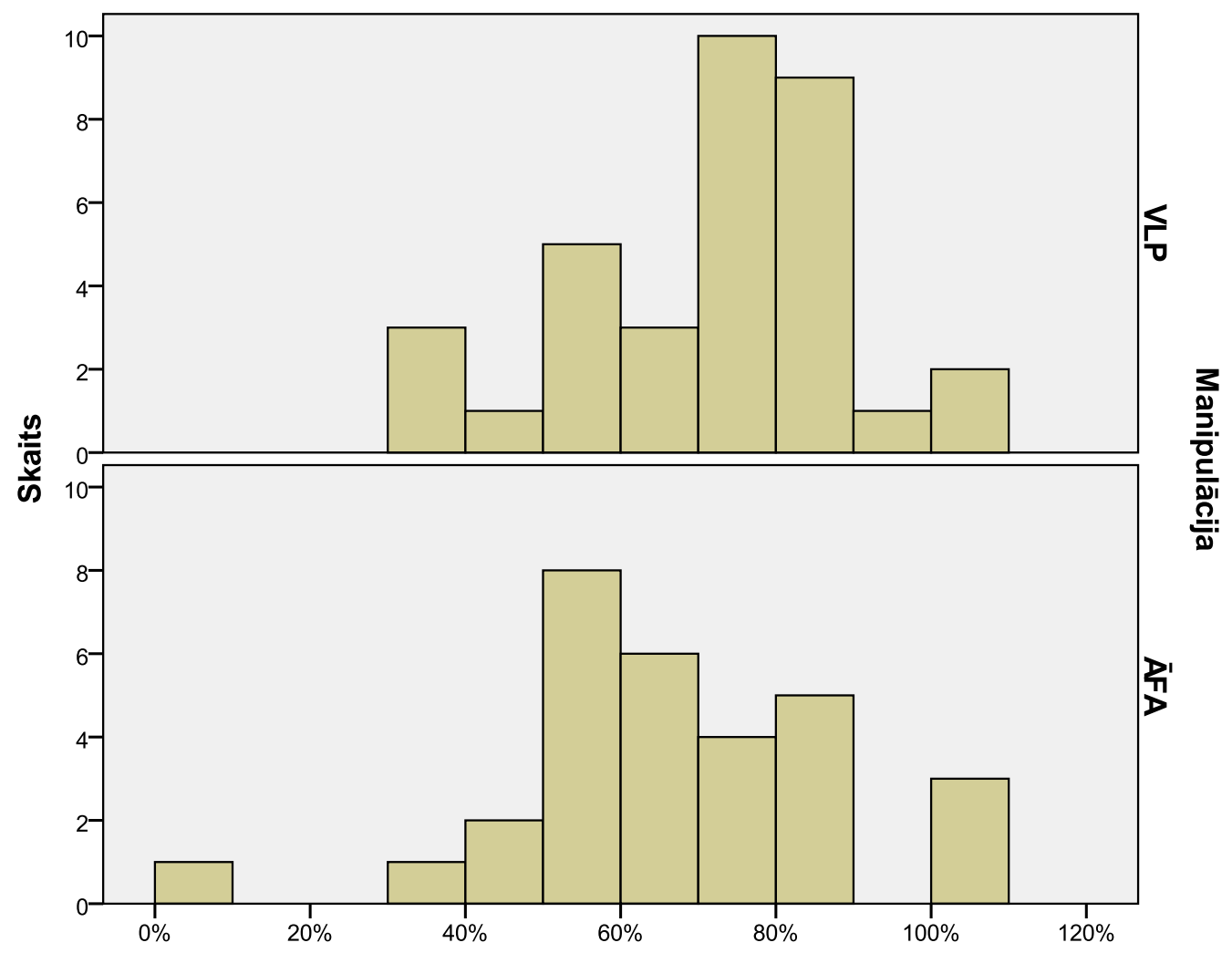

Plaukstas ulnāra deviācija 0-45 (3. mēnesis) 

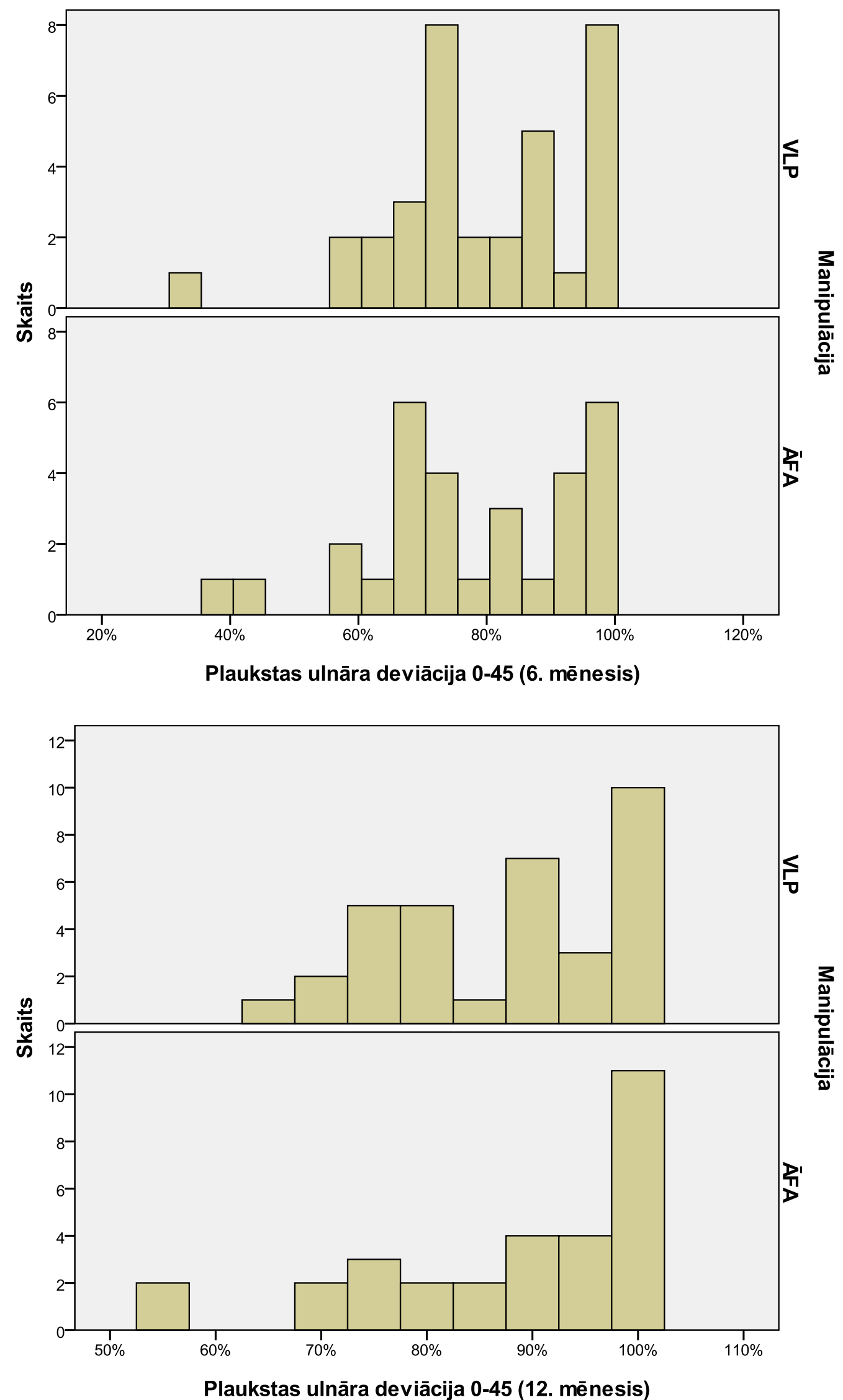

D

3.10. A, B, C, D attēls. Plaukstas ulnārās deviācijas rezultāti dinamikā 
Lai analizētu, vai plaukstas ulnārās deviācijas mērījumi statistiski būtiski atšķiras starp kontrolgrupām atkarībā no mēnešu skaita kopš operācijas, tika lietoti Mann-Whitney un Kolmogorova-Smirnova testi. Iegūti šādi rezultāti - statistiski būtiskas atšķirības plaukstas ulnārās deviācijas parametra vērtībās atkarībā no manipulācijas veida nav atrodamas nevienā mērījumā $(\mathrm{p}>0,05)$ pēc operācijas (sk. 3.12. tabulu).

3.12. tabula

Plaukstas ulnārās deviācijas mērījumi, lietojot Mann-Whitney un Kolmogorova-Smirnova testus

\begin{tabular}{|c|c|c|c|c|}
\hline & 1. mēn. & 3. mēn. & 6. mēn. & 12. mēn. \\
\hline $\begin{array}{l}\text { Ir statistiski būtiskas atšķirības starp } \\
\text { VLP un ĀFA grupu }\end{array}$ & $\mathrm{ne \overline { }}$ & nē & nē & nē \\
\hline p-vērtība (Mann-Whitney tests) & 0,536 & 0,284 & 0,655 & 0,686 \\
\hline p-vērtība (Kolmogorova-Smirnova tests) & 0,828 & 0,252 & 0,946 & 0,980 \\
\hline
\end{tabular}

P-vērtības sakrīt ar Asymp. Sig. (2-tailed) aprēḳinu materiālos. Ja kolonnā kaut viena p-vērtība mazāka vai vienāda ar 0,05 , raksta "jā̄", pretējā gadījumā "nē".

Lai noskaidrotu, vai plaukstas ulnārās deviācijas mērījumi statistiski būtiski uzlabojas, ritot laikam pēc operācijas, tiek lietoti Wilcoxon Signed Ranks un Sign testi. Iegūti šādi rezultāti - abi testi rāda statistiski būtisku, monotonu plaukstas ulnārās deviācijas parametra uzlabojumu, ritot laikam pēc operācijas abās pētījumu grupās ( $\mathrm{p}<0,01)$ (sk. 3.13. tabulu).

3.13. tabula

Plaukstas ulnārās deviācijas mērījumi, lietojot Wilcoxon Signed Ranks un Sign testus

\begin{tabular}{|l|c|c|c|}
\cline { 2 - 4 } \multicolumn{1}{c|}{} & $\begin{array}{c}\text { 3. mēn. } \\
\text { pret 1. mēn. }\end{array}$ & $\begin{array}{c}\mathbf{6 .} \text { mēn } \\
\text { pret 3. mēn. }\end{array}$ & $\begin{array}{c}\text { 12. mēn } \\
\text { pret 6. mēn. }\end{array}$ \\
\hline $\begin{array}{l}\text { Ir statistiski būtisks uzlabojums } \\
\text { (VLP grupa) }\end{array}$ & $\mathrm{jā}$ & $\mathrm{jā}$ & $\mathrm{jā}$ \\
\hline $\begin{array}{l}\text { Ir statistiski būtisks uzlabojums } \\
\text { (ĀFA grupa) }\end{array}$ & $\mathrm{j} \overline{\mathrm{a}}$ & $\mathrm{j} \overline{\mathrm{a}}$ & $\mathrm{jā}$ \\
\hline $\begin{array}{l}\text { p-vērtība (Wilcoxon Signed Ranks } \\
\text { tests) VLP grupai }\end{array}$ & $\mathbf{0 , 0 0 0}$ & $\mathbf{0 , 0 0 9}$ & $\mathbf{0 , 0 0 6}$ \\
\hline p-vērtība (Sign tests) VLP grupai & $\mathbf{0 , 0 0 0}$ & 0,072 & $\mathbf{0 , 0 4 5}$ \\
\hline $\begin{array}{l}\text { p-vērtība (Wilcoxon Signed Ranks } \\
\text { tests) ĀFA grupai }\end{array}$ & $\mathbf{0 , 0 0 0}$ & $\mathbf{0 , 0 0 3}$ & $\mathbf{0 , 0 0 0}$ \\
\hline p-vērtība (Sign tests) ĀFA grupai & $\mathbf{0 , 0 0 1}$ & 0,063 & $\mathbf{0 , 0 0 0}$ \\
\hline
\end{tabular}

P-vērtības sakrīt ar Asymp. Sig. (2-tailed) / 2 aprēķinu materiālos. Ja kolonnā kaut viena p-vērtība mazāka vai vienāda ar 0,05 , raksta “jā̄", pretējā gadījumā "nē". 


\subsubsection{Apakšdelma pronācija}

Lietojot standarta statistiskas metodologiju apakšdelma pronācijas vidējās vērtības noteikšanai atkarībā no manipulācijas veida un pagājušā laika intervāla pēc operācijas, ieguvām šādas vidējās vērtības (95 \% ticamības intervālus) (sk. 3.14. tabulu).

3.14. tabula

Apakšdelma pronācijas vidējās vērtības

\begin{tabular}{|l|c|c|c|c|}
\cline { 2 - 5 } \multicolumn{1}{c|}{} & 1. mēn. & 3. mēn. & 6. mēn. & 12. mēn. \\
\hline VLP grupa, \% & $69,8 \pm 7,0$ & $92 \pm 3,5$ & $99,2 \pm 1,0$ & $99,5 \pm 1,1$ \\
\hline ĀFA grupa, \% & $63,1 \pm 7,5$ & $91,1 \pm 4,6$ & $97,8 \pm 1,6$ & $99,3 \pm 1,0$ \\
\hline
\end{tabular}

Aprēķina pēc formulas Mean \pm (Mean Upper Bound - Mean Lower Bound) / 2.

Mērījumu rezultātu vizualizācija skatāma 3.11. un 3.12. A, B, C, D attēlā.

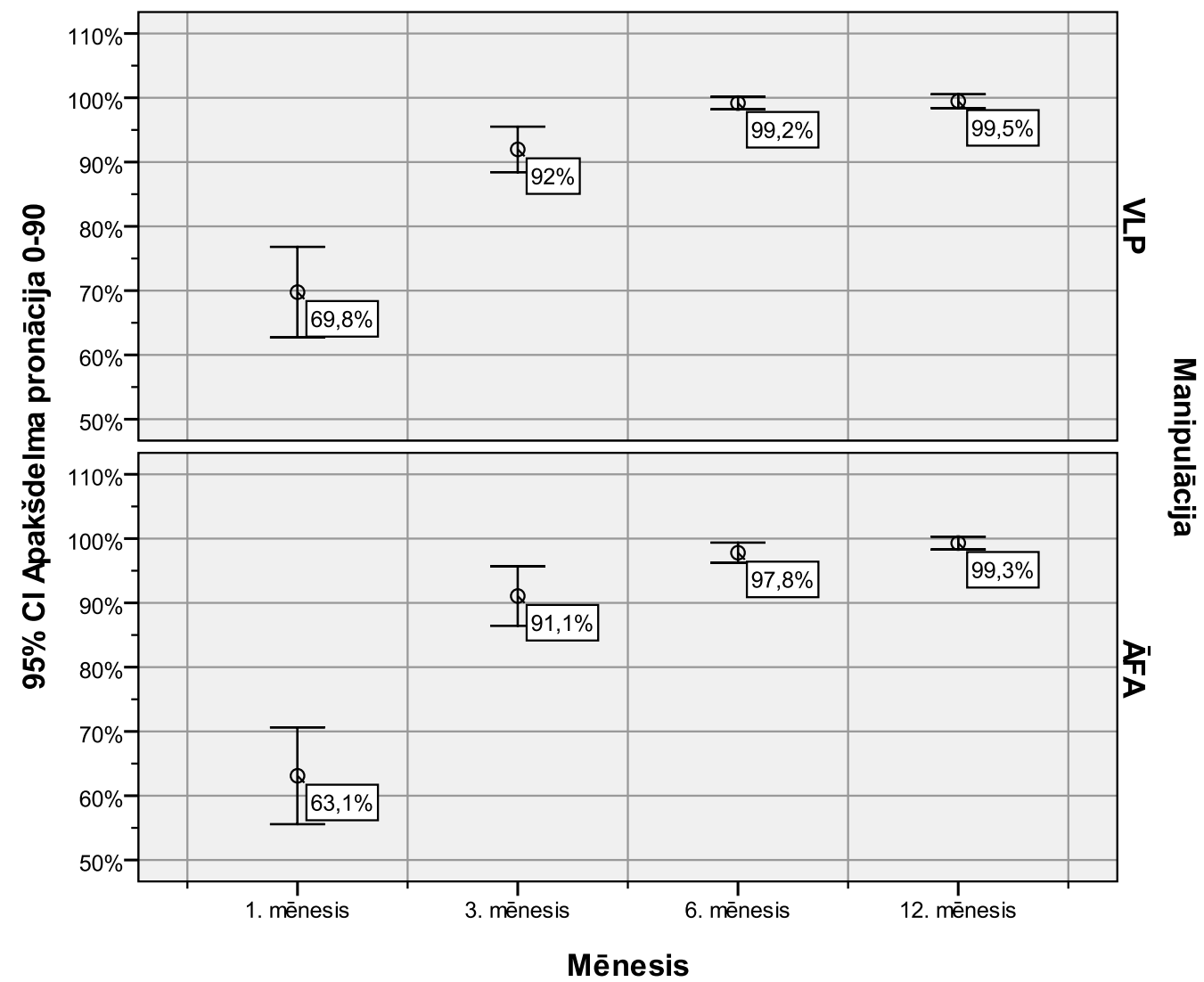

3.11. attēls. Apakšdelma pronācijas vērtības atkarībā no manipulācijas veida un pagājušā laika intervāla pēc operācijas 


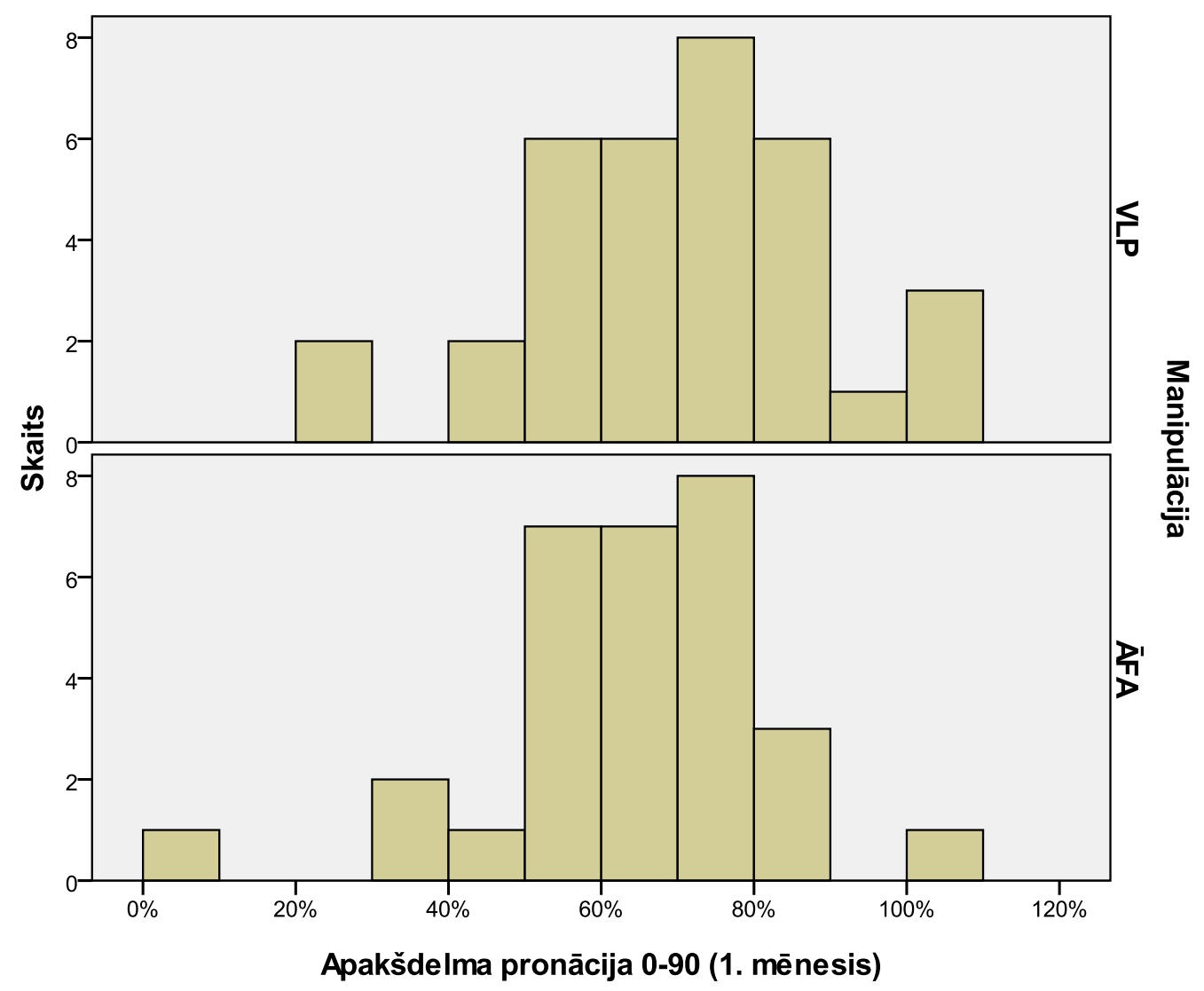

A

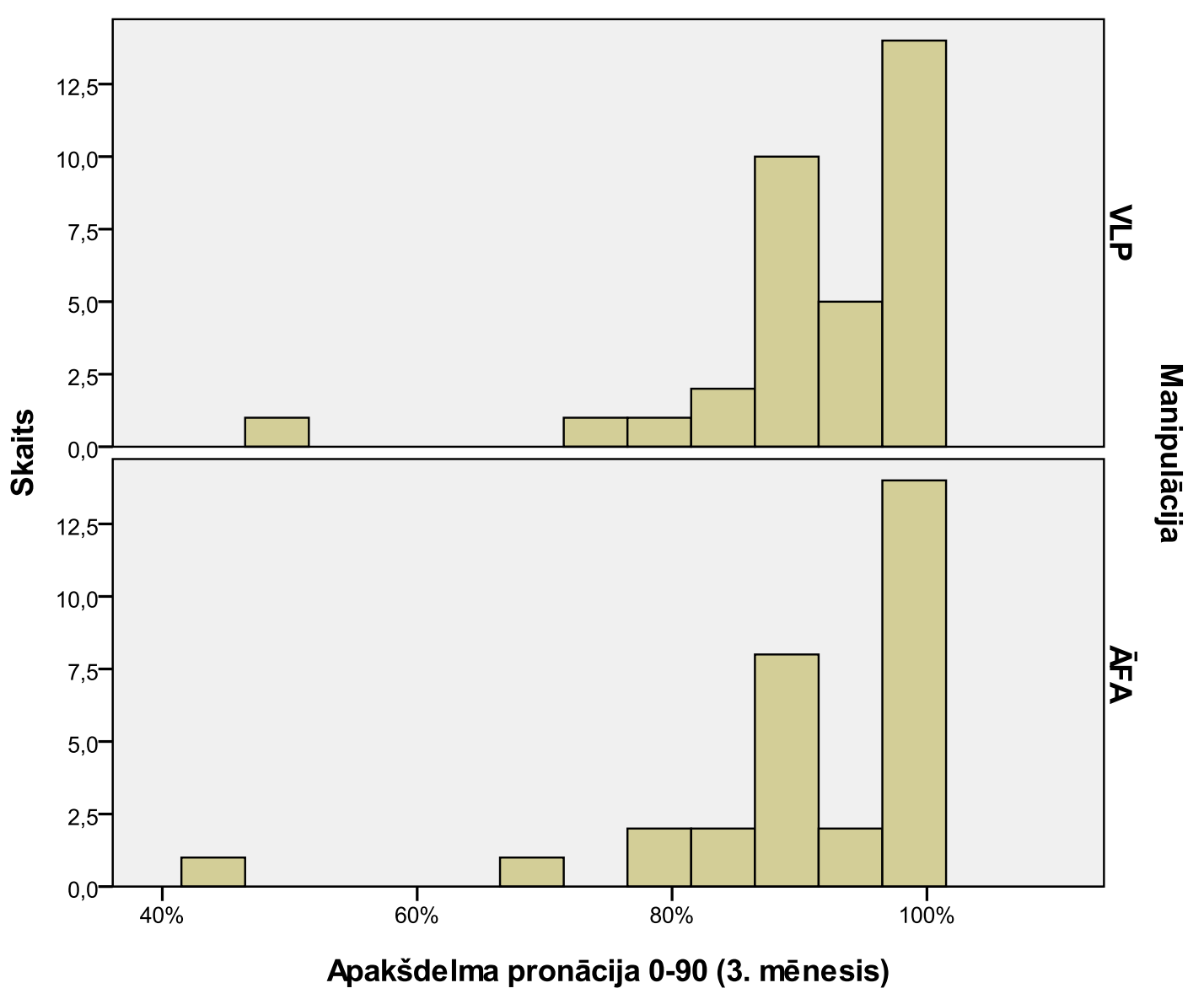




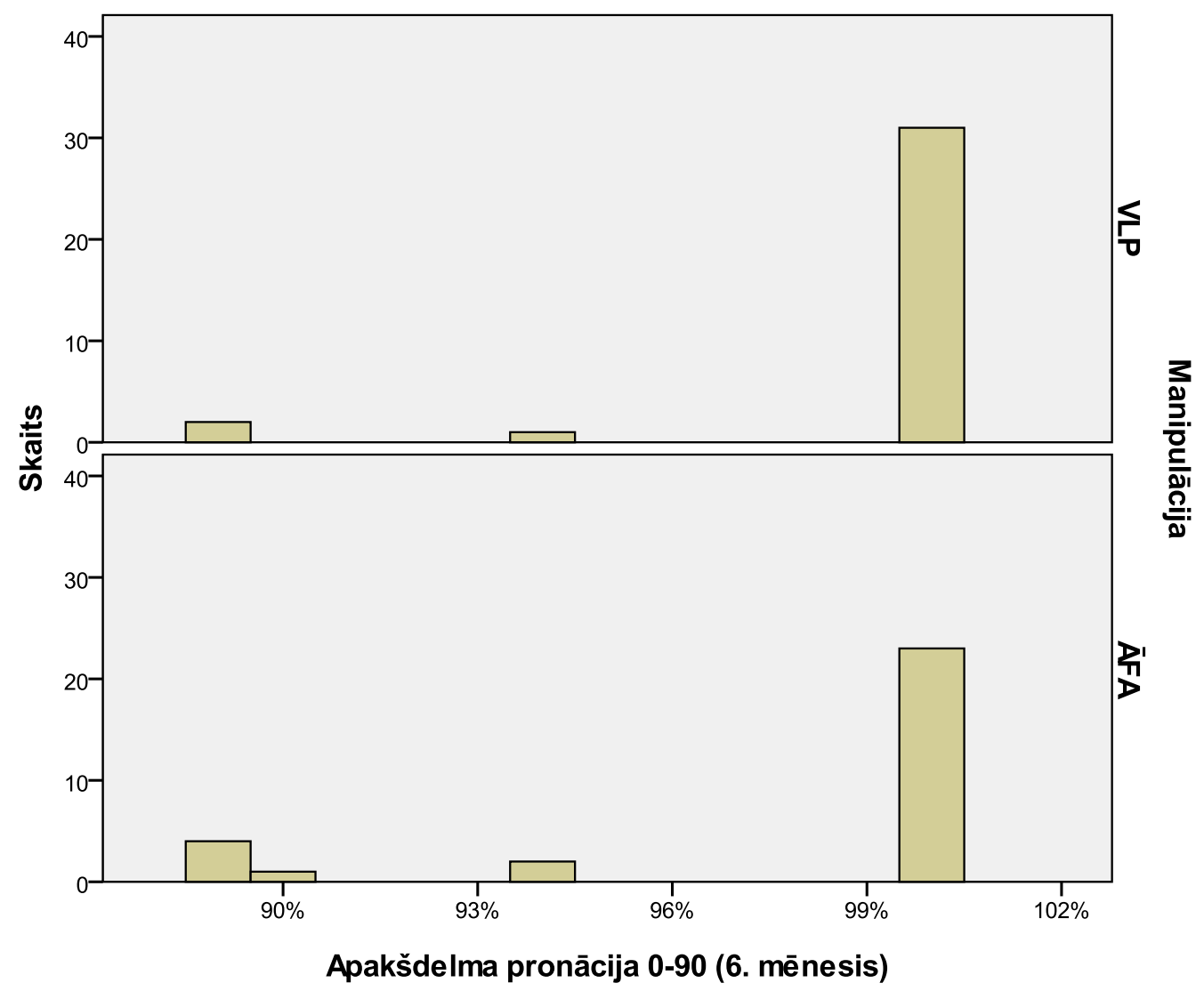

C

Apakšdelma pronācija 0-90 (6. mēnesis)

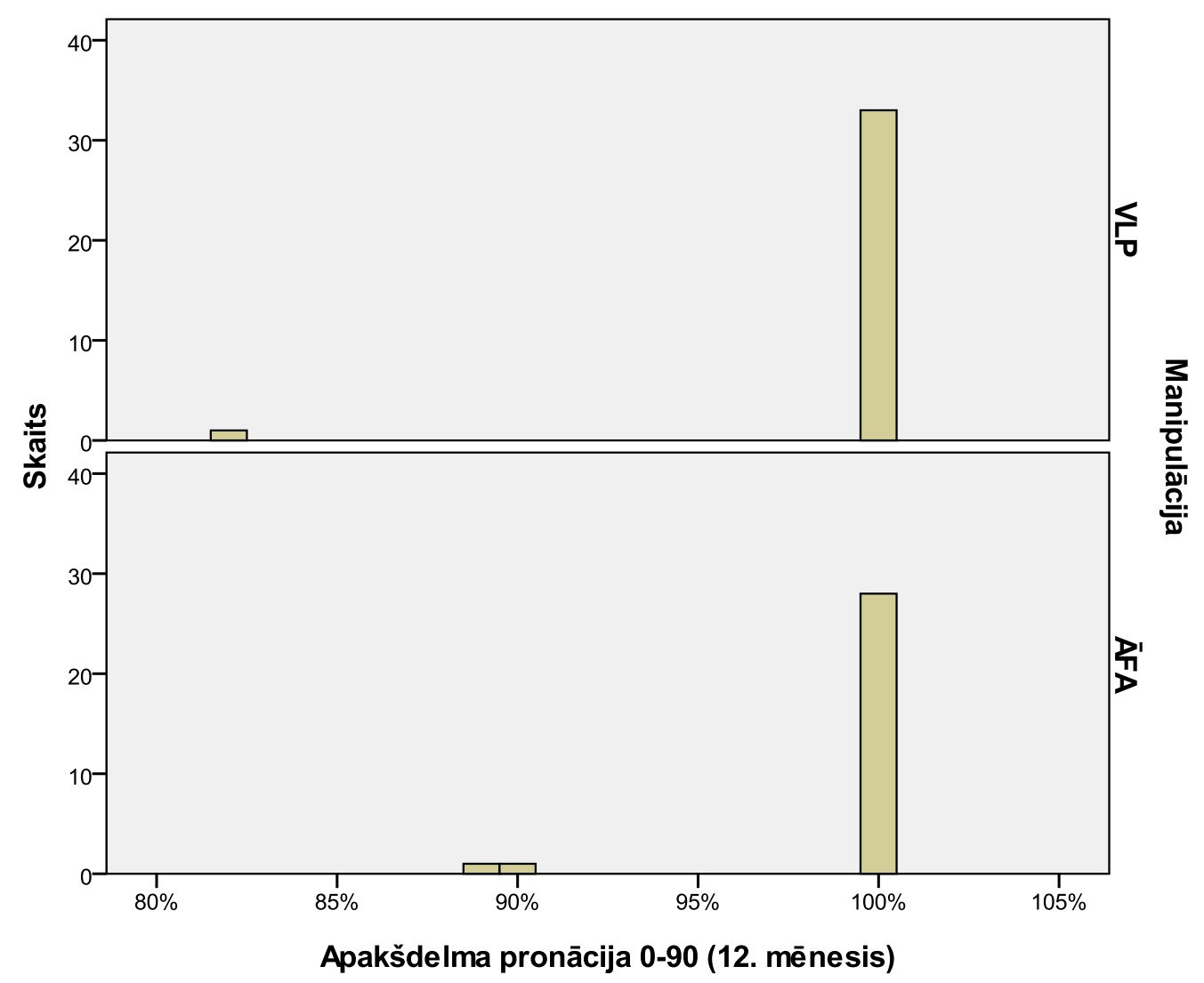

3.12. A, B, C, D attēls. Apakšdelma pronācijas rezultāti dinamikā 
Lai analizētu, vai apakšdelma pronācijas mērījumi statistiski būtiski atšķiras starp kontrolgrupām atkarībā no mēnešu skaita kopš operācijas, tika lietoti Mann-Whitney un Kolmogorova-Smirnova testi. Iegūti šãdi rezultāti - statistiski būtiskas atšķirības apakšdelma pronācijas parametra vērtībās atkarībā no manipulācijas veida nav sastopamas nevienā mērījumā $(\mathrm{p}>0,05)$ pēc operācijas (sk. 3.15. tabulu).

3.15. tabula

Apakšdelma pronācijas mērījumi, lietojot Mann-Whitney un Kolmogorova-Smirnova testus

\begin{tabular}{|l|c|c|c|c|}
\cline { 2 - 5 } \multicolumn{1}{c|}{} & 1. mēn. & 3. mēn. & 6. mēn. & 12. mēn. \\
\hline $\begin{array}{l}\text { Ir statistiski būtiskas atšķirīibas starp } \\
\text { VLP un ĀFA grupu }\end{array}$ & nē & nē & nē & nē \\
\hline p-vērtība (Mann-Whitney tests) & 0,214 & 0,955 & 0,117 & 0,509 \\
\hline p-vērtîba (Kolmogorova-Smirnova tests) & 0,768 & 1,000 & 0,890 & 1,000 \\
\hline
\end{tabular}

P-vērtības sakrīt ar Asymp. Sig. (2-tailed) aprēḳinu materiālos. Ja kolonnā kaut viena p-vērtība mazāka vai vienāda ar 0,05 , raksta "jā̄", pretējā gadījumā "nē".

Lai noskaidrotu, vai apakšdelma pronācijas mērījumi statistiski būtiski uzlabojas, ritot laikam pēc operācijas, tiek lietoti Wilcoxon Signed Ranks un Sign testi. Iegūti šādi rezultāti abi testi rāda statistiski būtisku, monotonu apakšdelma pronācijas parametra uzlabojumu, ritot laikam pēc operācijas abās pētījumu grupās ( $\mathrm{p}<0,01$ ), bet VLP grupā uzlabojums starp 6. un 12. mēnesi pēc operācijas vairs nav statistiski būtisks ( $p>0,05)$ (sk. 3.16. tabulu).

3.16. tabula

Apakšdelma pronācijas mērījumi, lietojot Wilcoxon Signed Ranks un Sign testus

\begin{tabular}{|l|c|c|c|}
\cline { 2 - 4 } \multicolumn{1}{c|}{} & $\begin{array}{c}\text { 3. mēn. } \\
\text { pret 1. mēn. }\end{array}$ & $\begin{array}{c}\mathbf{6} \text {. mēen } \\
\text { pret 3. mēn. }\end{array}$ & $\begin{array}{c}\text { 12. mēn } \\
\text { pret 6. mēn. }\end{array}$ \\
\hline $\begin{array}{l}\text { Ir statistiski būtisks uzlabojums } \\
\text { (VLP grupa) }\end{array}$ & jā & $j \bar{a}$ & nē \\
\hline $\begin{array}{l}\text { Ir statistiski būtisks uzlabojums } \\
\text { (ĀFA grupa) }\end{array}$ & jā & $j \bar{a}$ & jā \\
\hline $\begin{array}{l}\text { p-vērtība (Wilcoxon Signed Ranks } \\
\text { tests) VLP grupai }\end{array}$ & $\mathbf{0 , 0 0 0}$ & $\mathbf{0 , 0 0 0}$ & 0,713 \\
\hline p-vērtība (Sign tests) VLP grupai & $\mathbf{0 , 0 0 0}$ & $\mathbf{0 , 0 0 0}$ & 0,625 \\
\hline $\begin{array}{l}\text { p-vērtība (Wilcoxon Signed Ranks } \\
\text { tests) ĀFA grupai }\end{array}$ & $\mathbf{0 , 0 0 0}$ & $\mathbf{0 , 0 0 2}$ & $\mathbf{0 , 0 3 8}$ \\
\hline p-vērtība (Sign tests) ĀFA grupai & $\mathbf{0 , 0 0 0}$ & $\mathbf{0 , 0 0 7}$ & 0,063 \\
\hline
\end{tabular}

P-vērtības sakrīt ar Asymp. Sig. (2-tailed) / 2 aprēķinu materiālos. Ja kolonnā kaut viena p-vērtība mazāka vai vienāda ar 0,05 , raksta “jā̄", pretējā gadījumā "nē". 


\subsubsection{Apakšdelma supinācija}

Lietojot standarta statistiskas metodologiju apakšdelma supinācijas vidējās vērtības noteikšanai atkarībā no manipulācijas veida un pagājušā laika intervāla pēc operācijas, ieguvām šādas vidējās vērtības (95 \% ticamības intervālus) (sk. 3.17. tabulu).

3.17. tabula

Apakšdelma supinācijas vidējās vērtības

\begin{tabular}{|l|c|c|c|c|}
\cline { 2 - 5 } \multicolumn{1}{c|}{} & 1. mēn. & 3. mēn. & 6. mēn. & 12. mēn. \\
\hline VLP grupa, \% & $57,9 \pm 8,4$ & $87,4 \pm 4,3$ & $93,9 \pm 3,0$ & $96,6 \pm 2,3$ \\
\hline ĀFA grupa, \% & $41,0 \pm 7,8$ & $78,2 \pm 7,0$ & $88,7 \pm 3,6$ & $90,7 \pm 3,8$ \\
\hline
\end{tabular}

Aprēķina pēc formulas Mean \pm (Mean Upper Bound - Mean Lower Bound) / 2.

Mērījumu rezultātu vizualizācija skatāma 3.13. un 3.14. A, B, C, D attēlā.

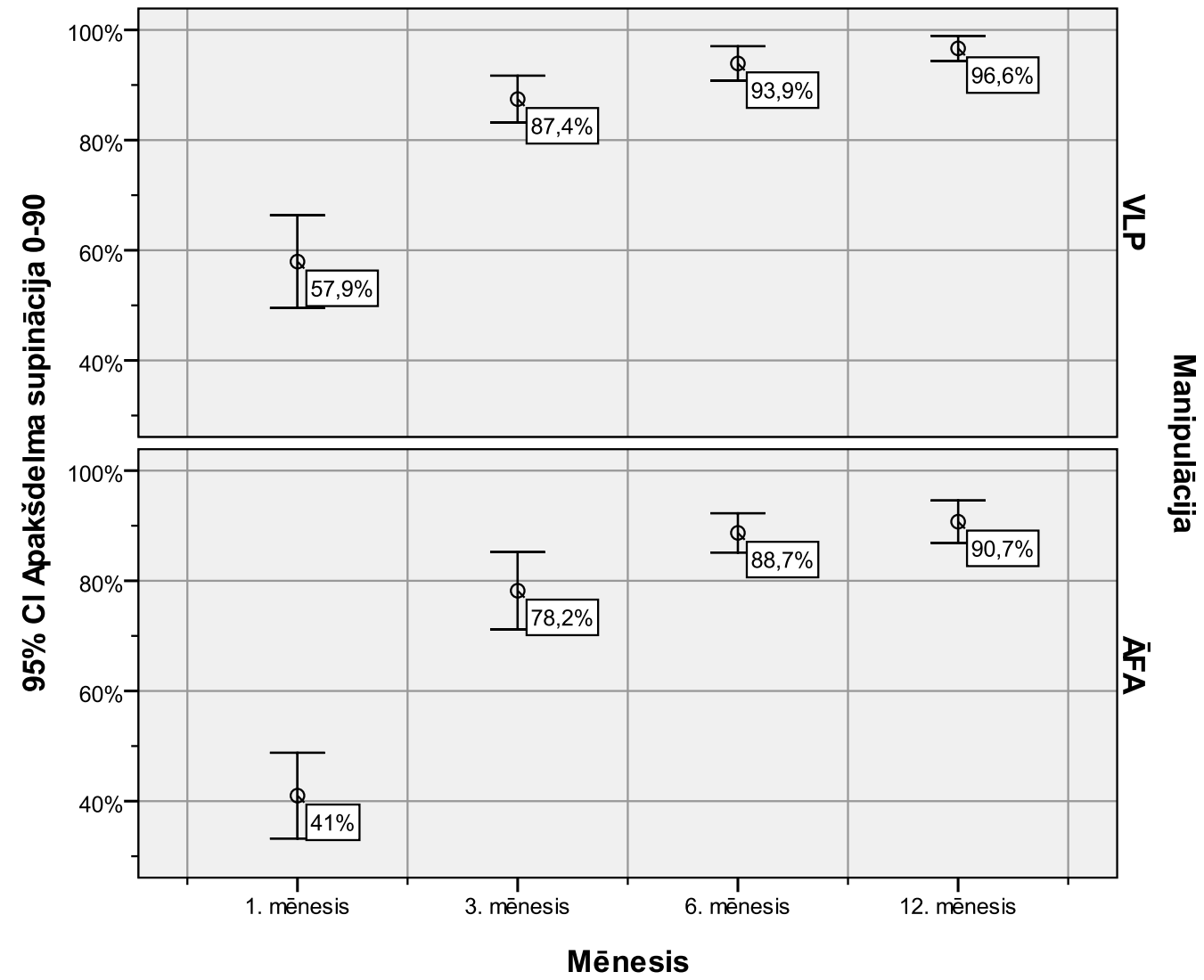

3.13. attēls. Apakšdelma supinācijas vērtības atkarībā no manipulācijas veida un pagājušā laika intervāla pēc operācijas 

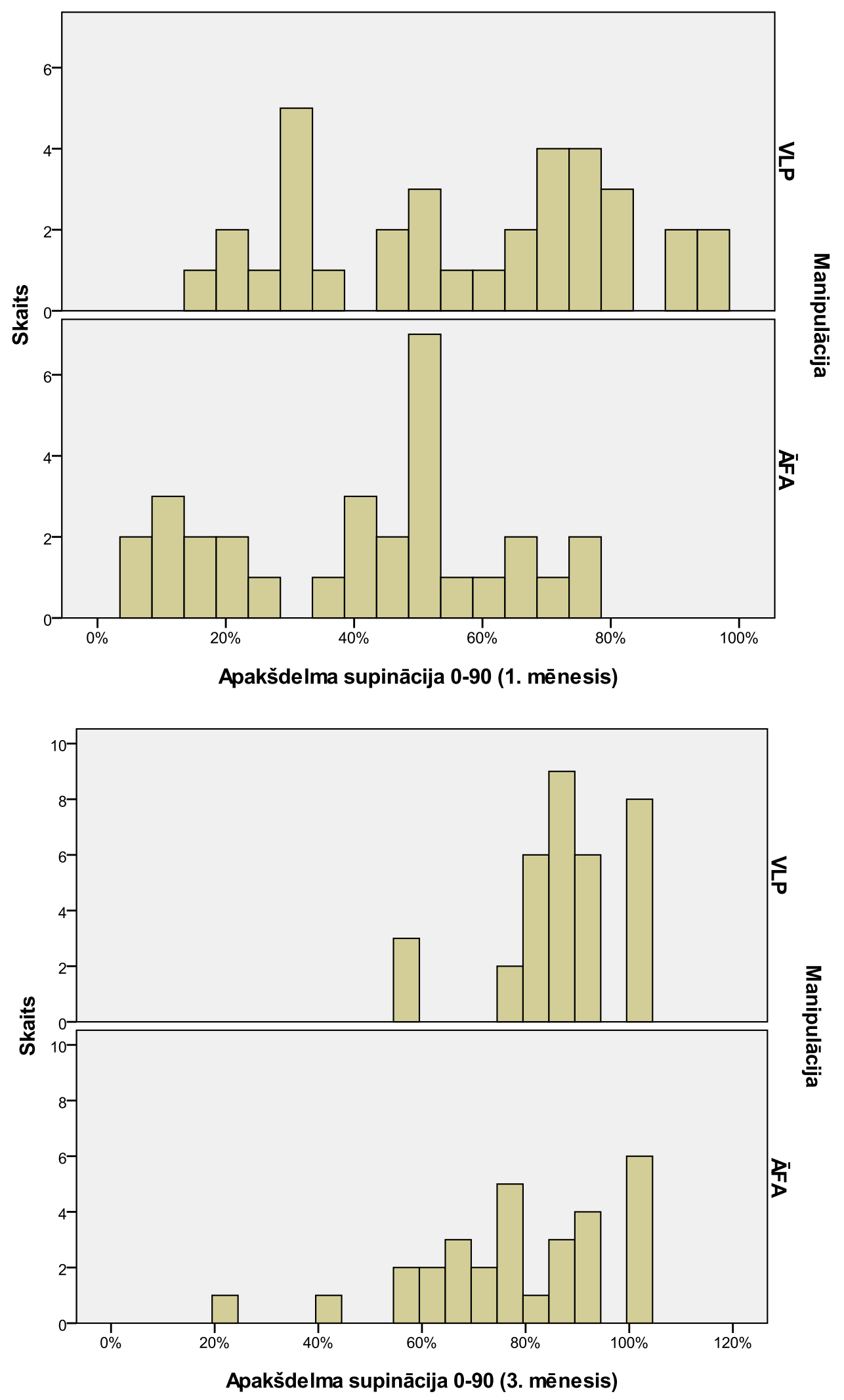

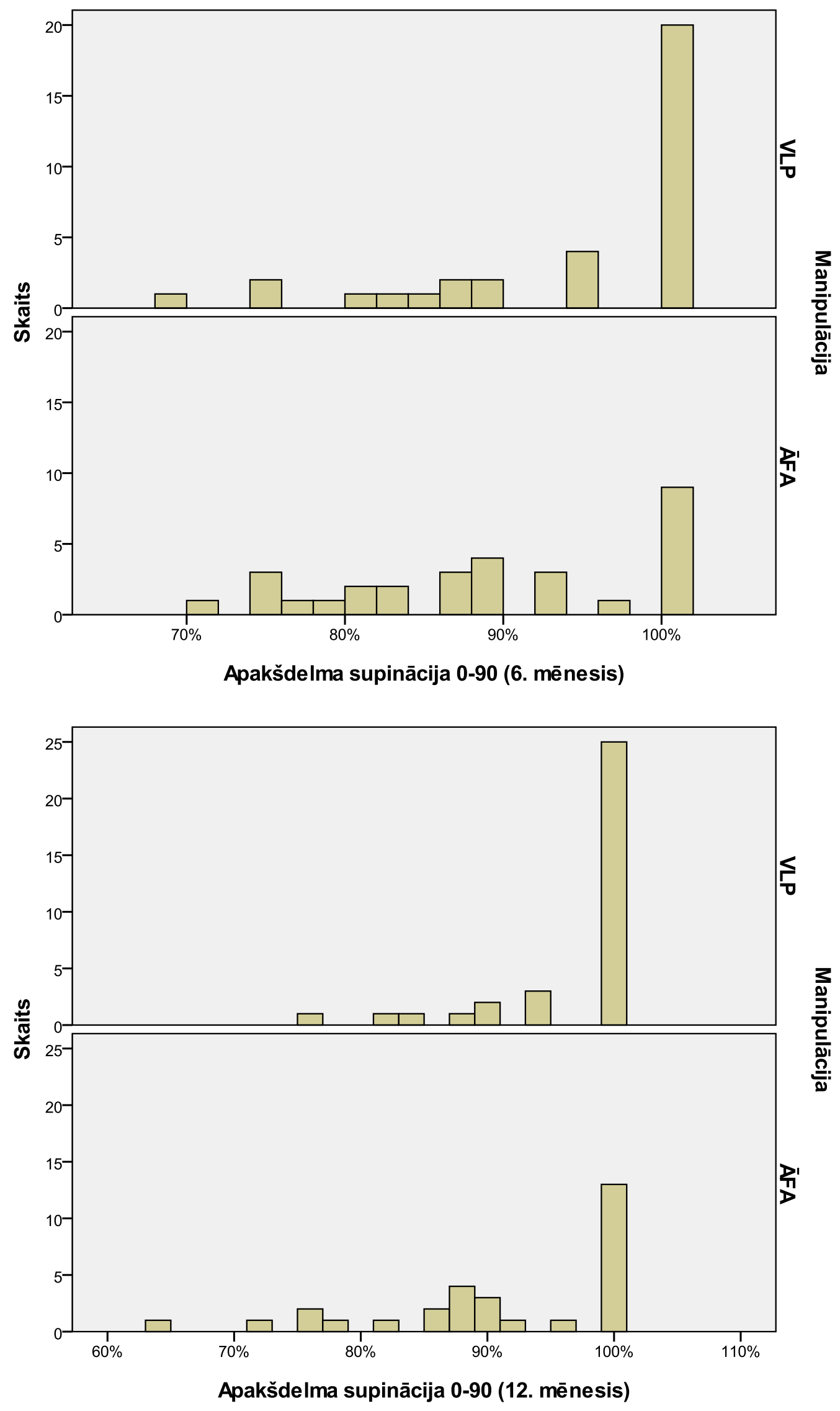

3.14. A, B, C, D attēls. Apakšdelma supinācijas rezultāti dinamikā 
Lai analizētu, vai apakšdelma supinācijas mērījumi statistiski būtiski atšķiras starp kontrolgrupām atkarībā no mēnešu skaita kopš operācijas, tika lietoti Mann-Whitney un Kolmogorova-Smirnova testi. Iegūti šãdi rezultāti - statistiski būtiskas atšḳirības apakšdelma pronācijas parametra vērtībās atkarībā no manipulācijas veida sastopamas visos mērījumos $(\mathrm{p}<0,05)$ pēc operācijas (sk. 3.18. tabulu).

3.18. tabula

Apakšdelma supinācijas mērījumi, lietojot Man-Whitney un Kolmogorova-Smirnova testus

\begin{tabular}{|c|c|c|c|c|}
\hline & 1. mēn. & 3. mēn. & 6. mēn. & 12. mēn. \\
\hline $\begin{array}{l}\text { Ir statistiski būtiskas atšķirības starp } \\
\text { VLP un ĀFA grupu }\end{array}$ & jā & $\mathrm{jā}$ & jā & $\mathrm{jā}$ \\
\hline p-vērtíba (Mann-Whitney tests) & $\mathbf{0 , 0 0 4}$ & 0,046 & $\mathbf{0 , 0 1 9}$ & 0,008 \\
\hline p-vērtība (Kolmogorova-Smirnova tests) & $\mathbf{0 , 0 2 3}$ & $\mathbf{0 , 0 1 7}$ & $\mathbf{0 , 0 2 4}$ & $\mathbf{0 , 0 3 5}$ \\
\hline
\end{tabular}

P-vērtības sakrīt ar Asymp. Sig. (2-tailed) aprēkinu materiālos. Ja kolonnā kaut viena p-vērtība mazāka vai vienāda ar 0,05 , raksta "jā", pretējā gadījumā "nē".

Lai noskaidrotu, vai apakšdelma supinācijas mērījumi statistiski būtiski uzlabojas, ritot laikam pēc operācijas, tiek lietoti Wilcoxon Signed Ranks un Sign testi. Iegūti šādi rezultāti abi testi rāda statistiski būtisku, monotonu apakšdelma supinācijas parametra uzlabojumu, ritot laikam pēc operācijas abās pētījumu grupās ( $p<0,01)$, bet ÂFA grupā uzlabojums starp 6. un 12. mēnesi pēc operācijas vairs nav statistiski būtisks ( $p$ > 0.05) (sk. 3.19. tabulu).

3.19. tabula

Apakšdelma supinācijas mērījumi, lietojot Wilcoxon Signed Ranks un Sign testus

\begin{tabular}{|l|c|c|c|}
\cline { 2 - 4 } \multicolumn{1}{c|}{} & $\begin{array}{c}\text { 3. mēen. } \\
\text { pret 1. mēn. }\end{array}$ & $\begin{array}{c}\mathbf{6} \text {. mēen } \\
\text { pret 3. mēn. }\end{array}$ & $\begin{array}{c}\text { 12. mēen } \\
\text { pret 6. mēn. }\end{array}$ \\
\hline $\begin{array}{l}\text { Ir statistiski būtisks uzlabojums } \\
\text { (VLP grupa) }\end{array}$ & jā & jā & jā \\
\hline $\begin{array}{l}\text { Ir statistiski būtisks uzlabojums } \\
\text { (ĀFA grupa) }\end{array}$ & jā & $j \bar{a}$ & nē \\
\hline $\begin{array}{l}\text { p-vērtība (Wilcoxon Signed Ranks } \\
\text { tests) VLP grupai }\end{array}$ & $\mathbf{0 , 0 0 0}$ & $\mathbf{0 , 0 0 0}$ & $\mathbf{0 , 0 4 8}$ \\
\hline $\begin{array}{l}\text { p-vērtība (Sign tests) } \\
\text { VLP grupai }\end{array}$ & $\mathbf{0 , 0 0 0}$ & $\mathbf{0 , 0 0 1}$ & 0,180 \\
\hline $\begin{array}{l}\text { p-vērtība (Wilcoxon Signed Ranks } \\
\text { tests) ĀFA grupai }\end{array}$ & $\mathbf{0 , 0 0 0}$ & $\mathbf{0 , 0 0 0}$ & 0,191 \\
\hline p-vērtība (Sign tests) ĀFA grupai & $\mathbf{0 , 0 0 0}$ & $\mathbf{0 , 0 0 2}$ & 0,115 \\
\hline
\end{tabular}

P-vērtības sakrīt ar Asymp. Sig. (2-tailed) / 2 aprēķinu materiālos. Ja kolonnā kaut viena p-vērtība mazāka vai vienāda ar 0,05 , raksta “jā̄", pretējā gadījumā "nē". 


\subsubsection{Plaukstas satvēriena spēks Grip}

Lietojot standarta statistiskas metodologiju plaukstas satvēriena spēka Grip vidējās vērtības noteikšanai atkarībā no manipulācijas veida un pagājušā laika intervāla pēc operācijas, ieguvām šādas vidējās vērtības (95\% ticamības intervālus) (sk. 3.20. tabulu).

3.20. tabula

Plaukstas satvēriena spēka Grip vidējās vērtības

\begin{tabular}{|l|c|c|c|c|}
\cline { 2 - 5 } \multicolumn{1}{c|}{} & 1. mēn. & 3. mēn. & 6. mēn. & 12. mēn. \\
\hline VLP grupa, \% & $27,7 \pm 5,9$ & $60,9 \pm 5,2$ & $80,4 \pm 5,3$ & $86,6 \pm 4,0$ \\
\hline ĀFA grupa, \% & $11,6 \pm 3,5$ & $53,8 \pm 5,8$ & $71,1 \pm 5,9$ & $85,7 \pm 4,8$ \\
\hline
\end{tabular}

Aprēķina pēc formulas Mean \pm (Mean Upper Bound - Mean Lower Bound) / 2.

Mērījumu rezultātu vizualizācija skatāma 3.15. un 3.16. A, B, C, D attēlā.

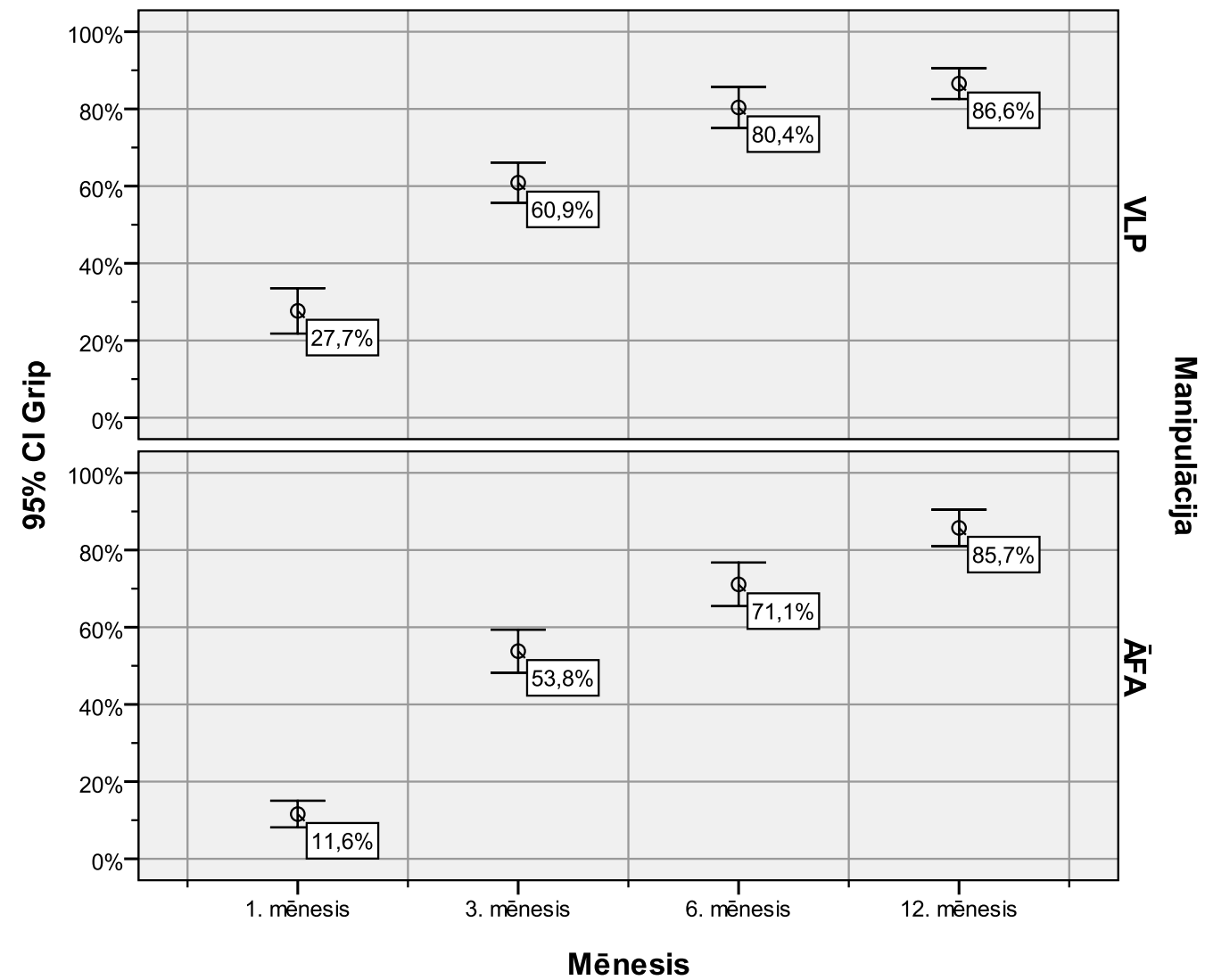

3.15. attēls. Plaukstas satvēriena spēka Grip vērtības atkarībā no manipulācijas veida un pagājušā laika intervāla pēc operācijas 


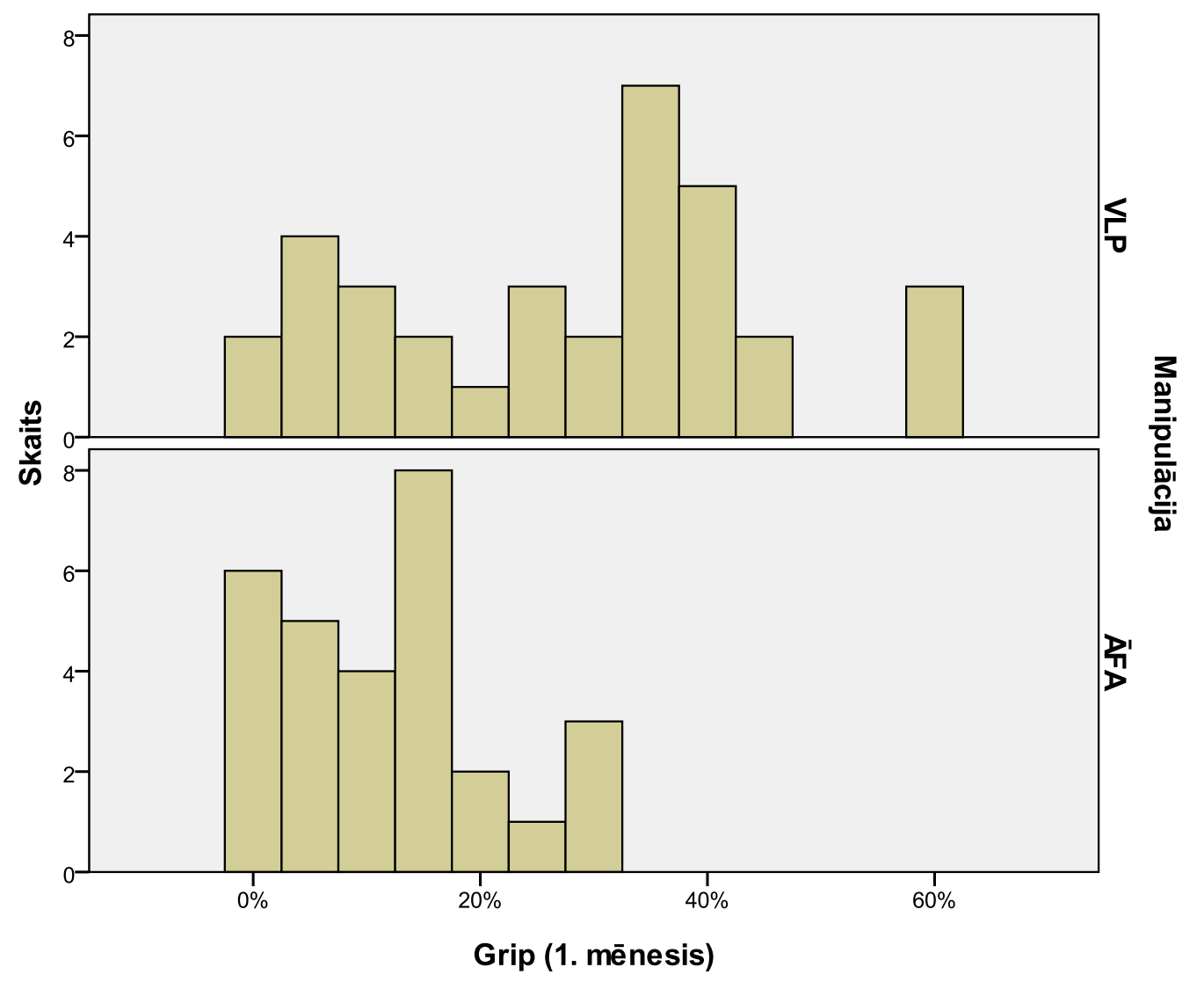

A

Grip (1. mēnesis)

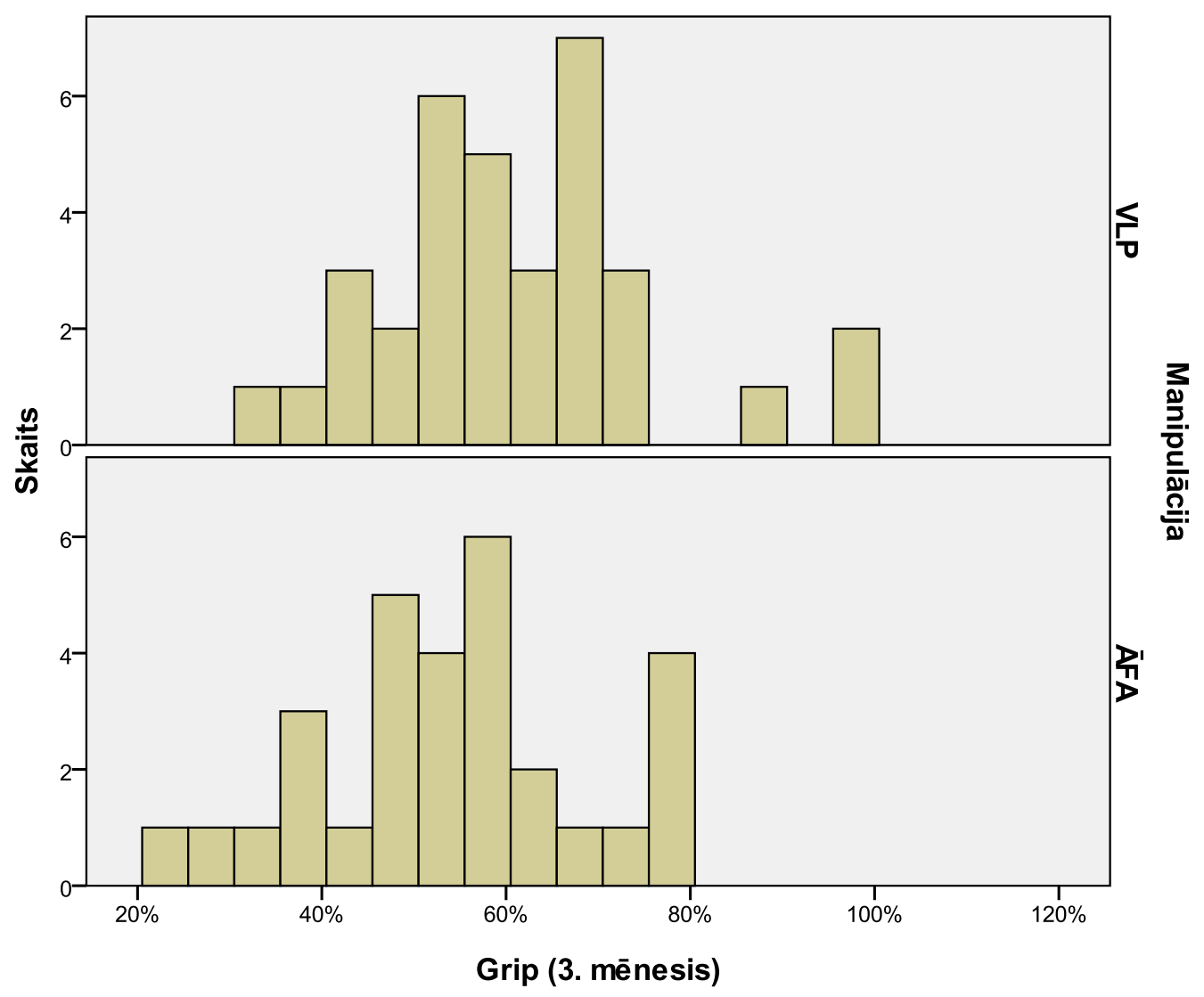



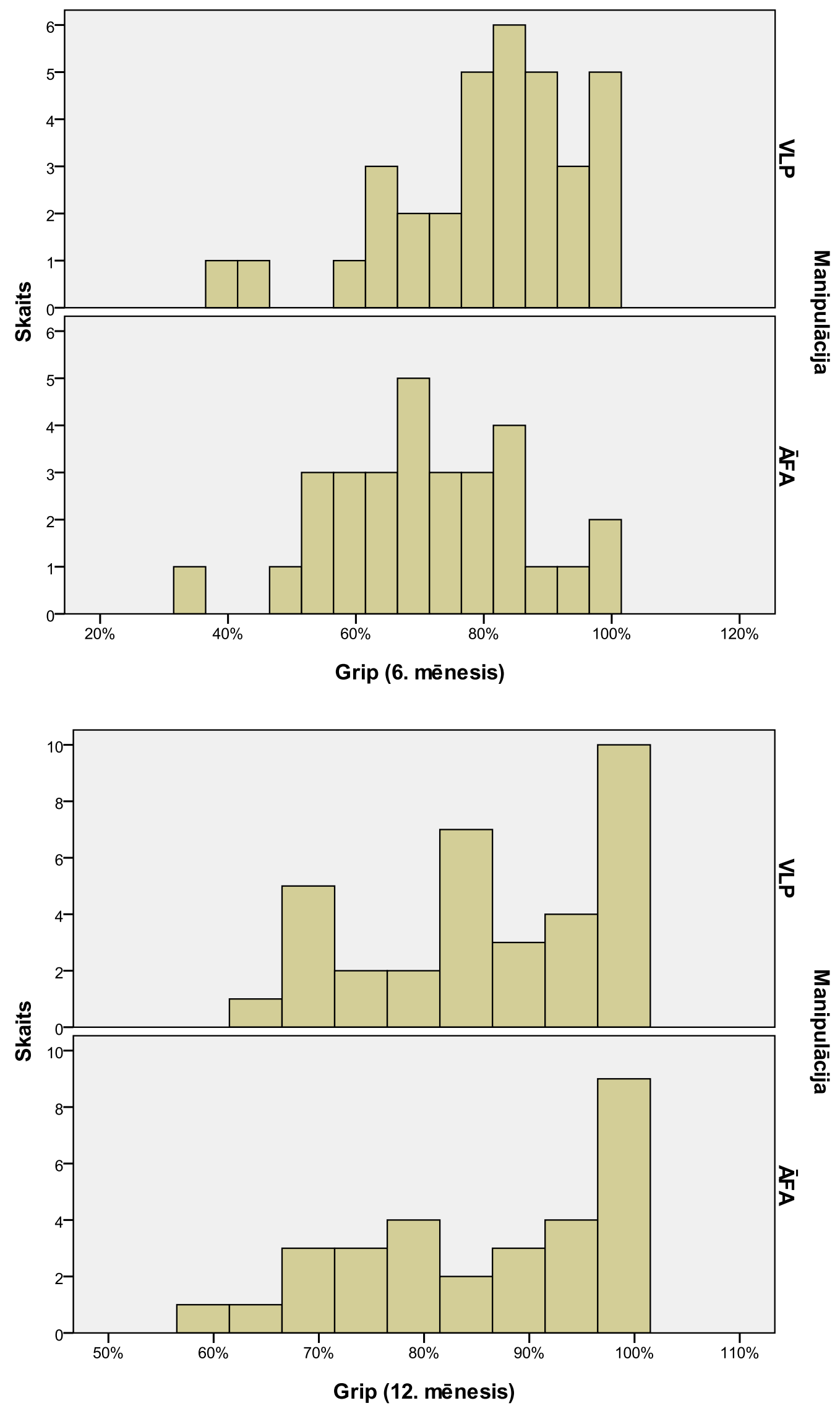

3.16. A, B, C, D attēls. Plaukstas satvēriena spēka Grip rezultāti dinamikā 
Lai analizētu, vai plaukstas satvēriena spēka Grip mērījumi statistiski būtiski atšķiras starp kontrolgrupām atkarībā no mēnešu skaita kopš operācijas, tika lietoti Mann-Whitney un Kolmogorova-Smirnova testi. Iegūti šādi rezultāti - statistiski būtiskas atšḳirības plaukstas satvēriena spēka Grip parametra vērtībās atkarībā no manipulācijas veida sastopamas 1. un 6. mēnes̄ì ( $\mathrm{p}<0,05)$ pēc operācijas, savukārt 3. un 12. mēnesī pēc operācijas statistiski būtiskas atskirīibas netiek novērotas ( $\mathrm{p}>0,05)$ (sk. 3.21. tabulu).

3.21. tabula

\section{Plaukstas satvēriena spēka Grip mērījumi, lietojot Mann-Whitney} un Kolmogorova-Smirnova testus

\begin{tabular}{|l|c|c|c|c|}
\cline { 2 - 5 } \multicolumn{1}{c|}{} & 1. mēn. & 3. mēn. & 6. mēn. & 12. mēn. \\
\hline $\begin{array}{l}\text { Ir statistiski būtiskas atšķirīibas starp } \\
\text { VLP un ĀFA grupu }\end{array}$ & jā & nē & jā & nē \\
\hline p-vērtība (Mann-Whitney tests) & $\mathbf{0 , 0 0 0}$ & 0,081 & $\mathbf{0 , 0 0 9}$ & 0,870 \\
\hline p-vērtîba (Kolmogorova-Smirnova tests) & $\mathbf{0 , 0 0 0}$ & 0,351 & $\mathbf{0 , 0 3 9}$ & 0,994 \\
\hline
\end{tabular}

P-vētības sakrīt ar Asymp. Sig. (2-tailed) aprēķinu materiālos. Ja kolonnā kaut viena p-vērtība mazāka vai vienāda ar 0,05 , raksta "jā", pretējā gadījumā "nē".

Lai noskaidrotu, vai plaukstas satvēriena spēka Grip mērījumi statistiski būtiski uzlabojas, ritot laikam pēc operācijas, tiek lietoti Wilcoxon Signed Ranks un Sign testi. Iegūti šādi rezultāti - abi testi rāda statistiski būtisku, monotonu plaukstas satvēriena spēka Grip parametra uzlabojumu, ritot laikam pēc operācijas abās pētījumu grupās $(p<0,05)$ (sk. 3.22. tabulu).

3.22. tabula

Plaukstas satvēriena spēka Grip mērījumi, lietojot Wilcoxon Signed Ranks un Sign testus

\begin{tabular}{|c|c|c|c|}
\hline & $\begin{array}{l}\text { 3. mēn. } \\
\text { pret 1. mēn. }\end{array}$ & $\begin{array}{l}\text { 6. mēn. } \\
\text { pret 3. mēn. }\end{array}$ & $\begin{array}{l}\text { 12. mēn. } \\
\text { pret } 6 . \text { mēn. }\end{array}$ \\
\hline $\begin{array}{l}\text { Ir statistiski būtisks uzlabojums } \\
\text { (VLP grupa) }\end{array}$ & $\mathrm{jā}$ & $\mathrm{jā}$ & $\mathrm{jā}$ \\
\hline $\begin{array}{l}\text { Ir statistiski būtisks uzlabojums } \\
(\bar{A} F A \text { grupa })\end{array}$ & $\mathrm{jā}$ & jā & $\mathrm{ja}$ \\
\hline $\begin{array}{l}\text { p-vērtība (Wilcoxon Signed Ranks } \\
\text { tests) VLP grupai }\end{array}$ & $\mathbf{0 , 0 0 0}$ & $\mathbf{0 , 0 0 0}$ & $\mathbf{0 , 0 1 7}$ \\
\hline p-vērtība (Sign tests) VLP grupai & $\mathbf{0 , 0 0 0}$ & $\mathbf{0 , 0 0 0}$ & 0,026 \\
\hline $\begin{array}{l}\text { p-vērtība (Wilcoxon Signed Ranks } \\
\text { tests) ĀFA grupai }\end{array}$ & $\mathbf{0 , 0 0 0}$ & $\mathbf{0 , 0 0 0}$ & 0,000 \\
\hline p-vērtība (Sign tests) ĀFA grupai & $\mathbf{0 , 0 0 0}$ & $\mathbf{0 , 0 0 0}$ & $\mathbf{0 , 0 0 0}$ \\
\hline
\end{tabular}

P-vērtības sakrīt ar Asymp. Sig. (2-tailed) / 2 aprēķinu materiālos. Ja kolonnā kaut viena p-vērtība mazāka vai vienāda ar 0,05 , raksta "jā", pretêjā gadījumā "nē". 


\subsubsection{Atslēgas tvēriena spēks Key Pinch}

Lietojot standarta statistiskas metodologiju atslēgas tvēriena spēka Key Pinch vidējās vērtības noteikšanai atkarībā no manipulācijas veida un pagājušā laika intervāla pēc operācijas, ieguvām šādas vidējās vērtības (95 \% ticamības intervālus) (sk. 3.23. tabulu).

3.23. tabula

Atslēgas tvēriena spēka Key Pinch vidējās vērtības

\begin{tabular}{|l|c|c|c|c|}
\cline { 2 - 5 } \multicolumn{1}{c|}{} & 1. mēn. & 3. mēn. & 6. mēn. & 12. mēn. \\
\hline VLP grupa, \% & $44,0 \pm 8,0$ & $77,9 \pm 5,3$ & $86,6 \pm 4,4$ & $91,9 \pm 2,7$ \\
\hline ĀFA grupa, \% & $29,4 \pm 6,4$ & $75,8 \pm 6,8$ & $89,2 \pm 4,0$ & $90,7 \pm 3,9$ \\
\hline
\end{tabular}

Aprēķina pēc formulas Mean \pm (Mean Upper Bound - Mean Lower Bound) / 2.

Mērījumu rezultātu vizualizācija skatāma 3.17. un 3.18. A, B, C, D attēlā.

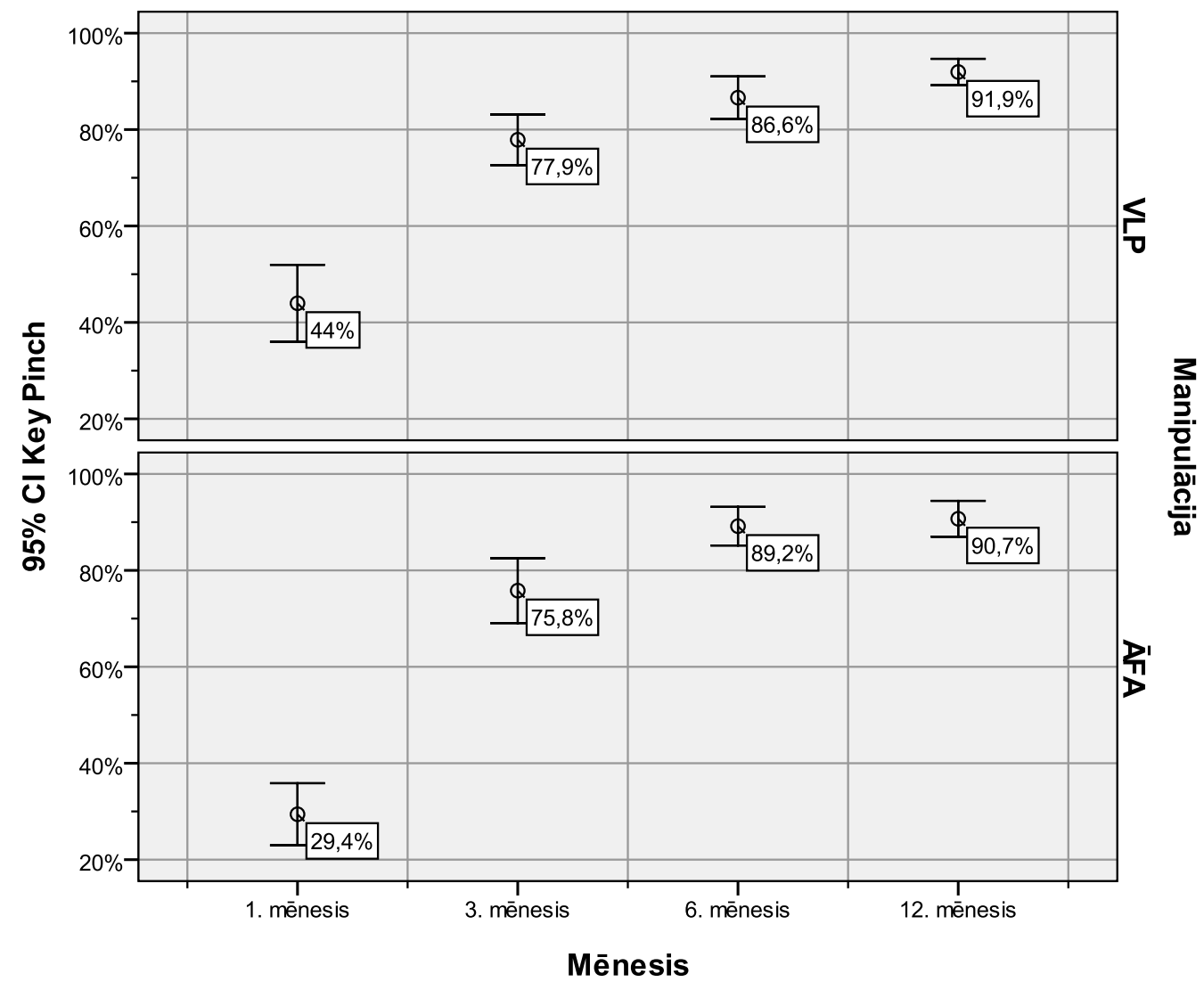

3.17. attēls. Plaukstas atslēgas tvēriena spēka Key Pinch vērtības atkarībā no manipulācijas veida un pagājušā laika intervāla pēc operācijas 


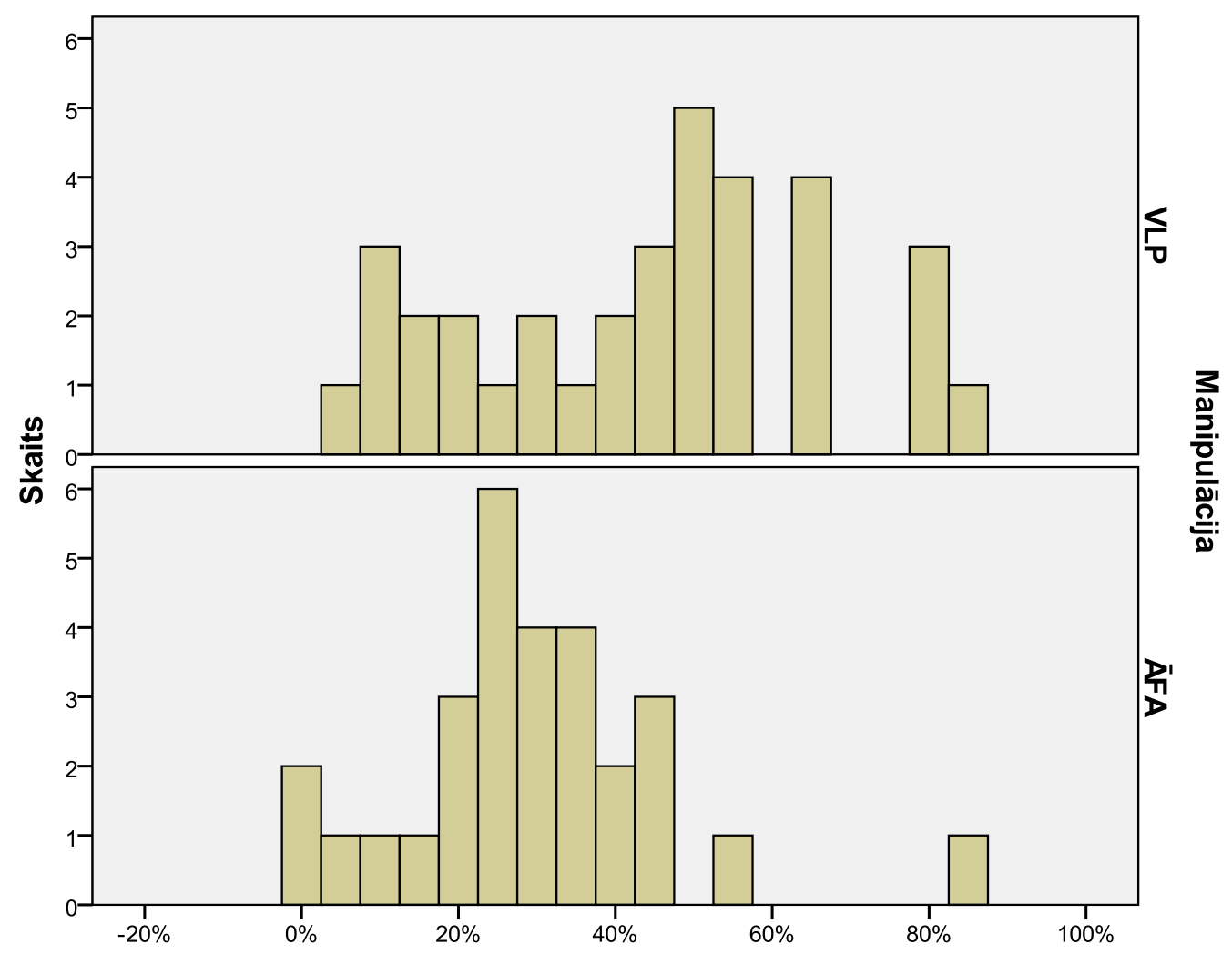

A

Key Pinch (1. mēnesis)

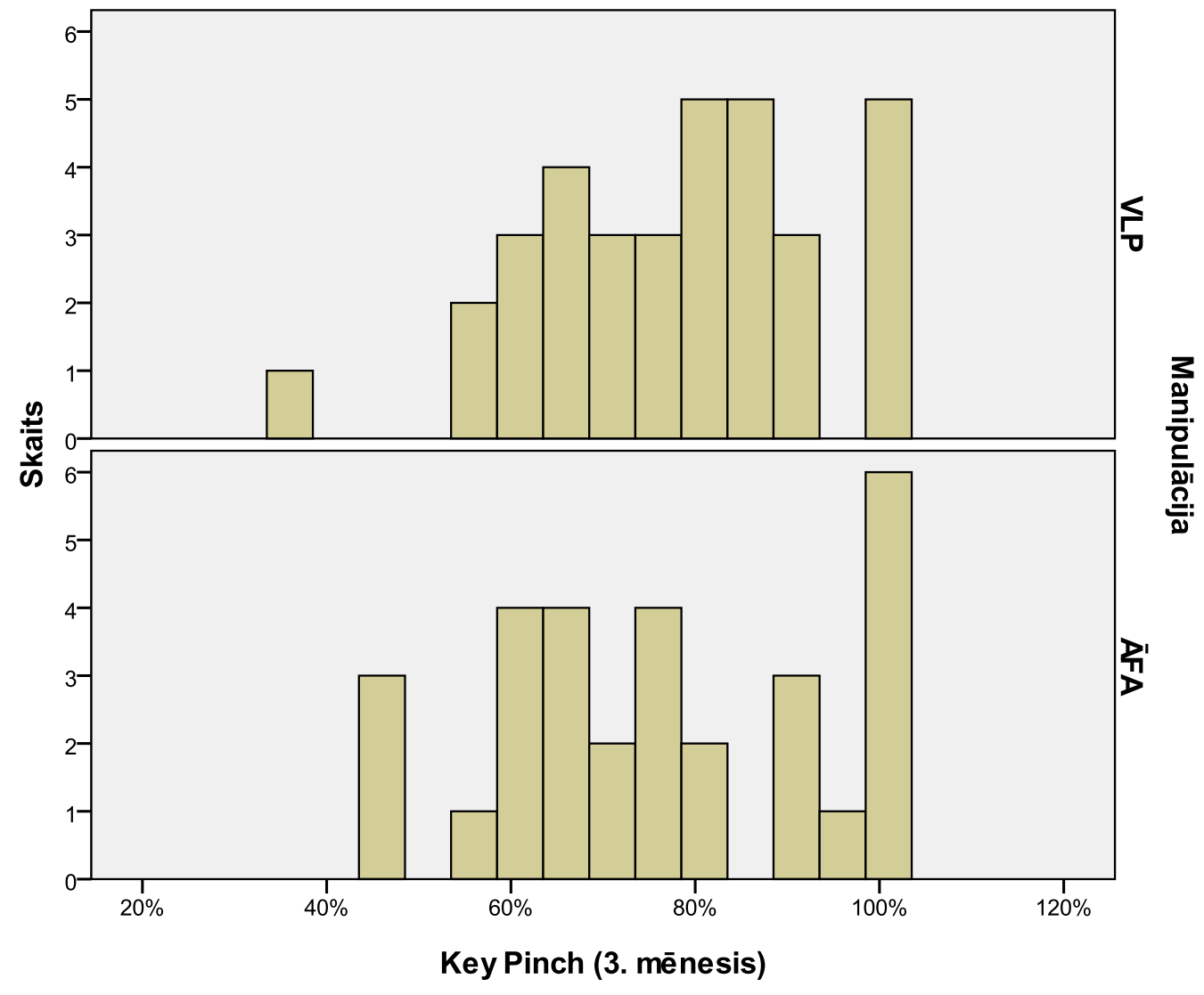




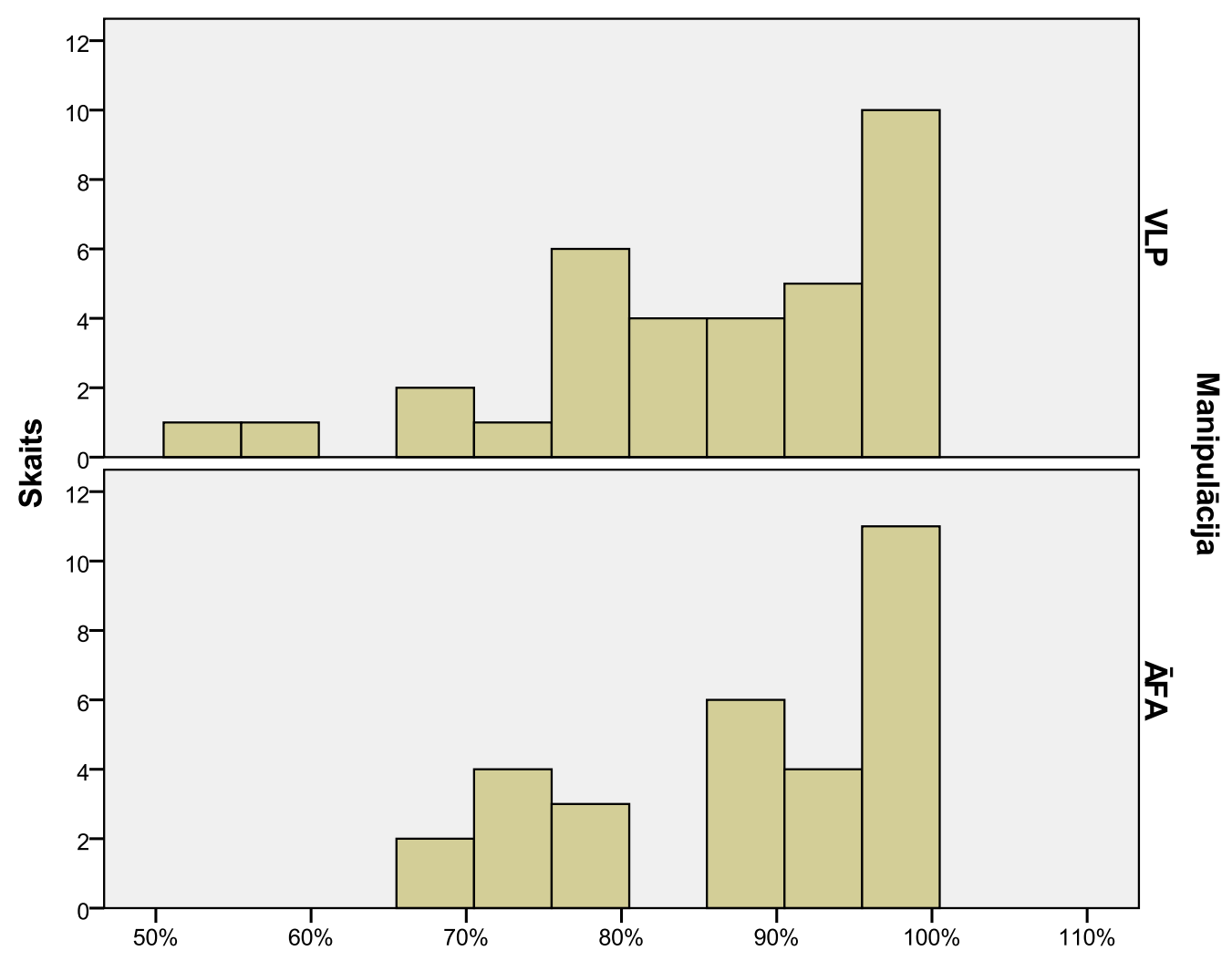

C

Key Pinch (6. mēnesis)

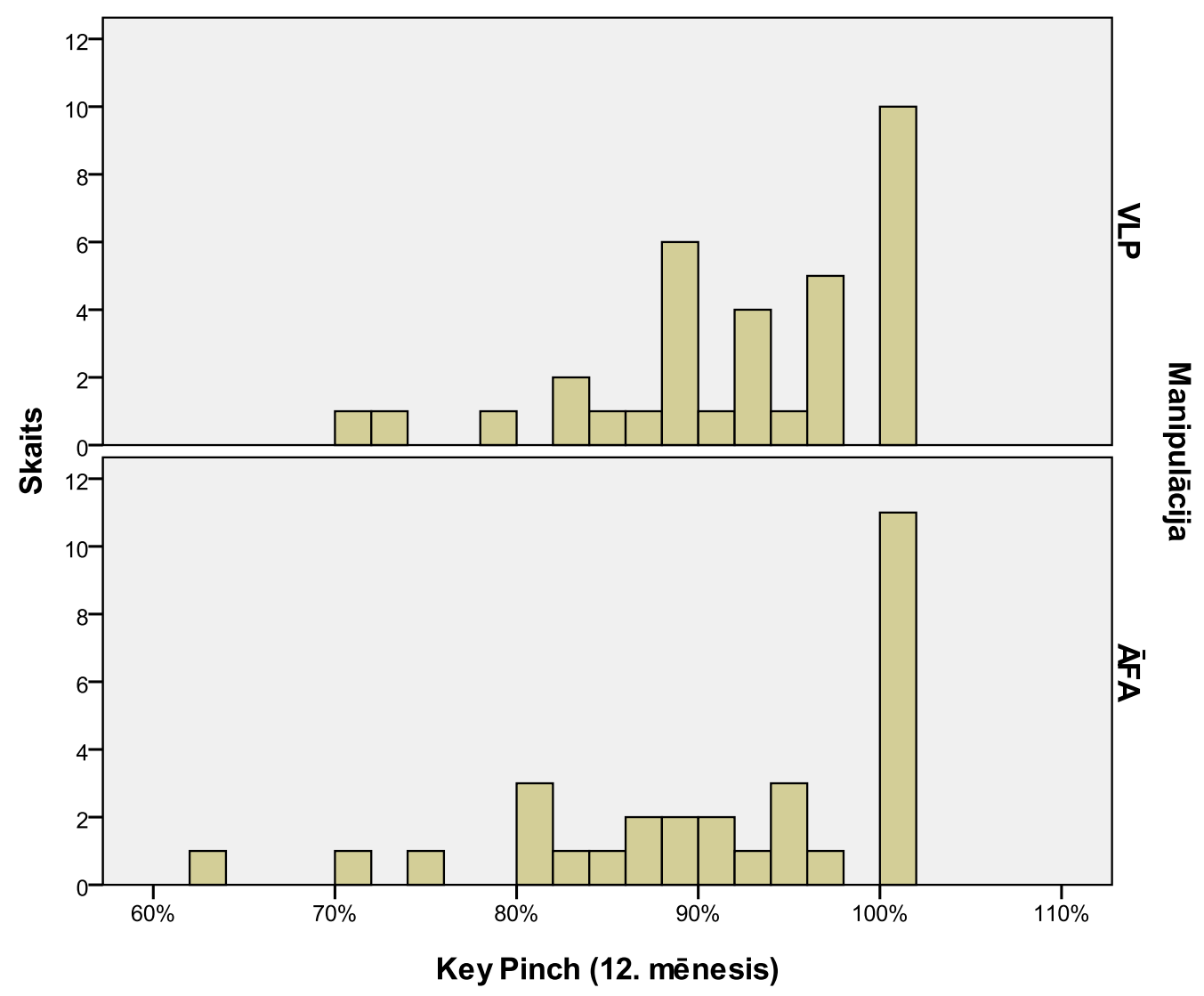

3.18. A, B, C, D attēls. Atslēgas tvēriena spēka Key Pinch rezultāti dinamikā 
Lai analizētu, vai atslēgas tvēriena spēka Key Pinch mērījumi statistiski būtiski atšḳiras starp kontrolgrupām atkarībā no mēnešu skaita kopš operācijas, tika lietoti Mann-Whitney un Kolmogorova-Smirnova testi. Iegūti šādi rezultāti - statistiski būtiskas atšḳirības atslēgas tvēriena spēka Key Pinch parametra vērtībās atkarībā no manipulācijas veida sastopamas tikai 1. mēnesī $(\mathrm{p}<0,05)$ (sk. 3.24. tabulu).

3.24. tabula

\section{Atslēgas tvēriena spēka Key Pinch mērījumi, lietojot Mann-Whitney un Kolmogorova-Smirnova testus}

\begin{tabular}{|c|c|c|c|c|}
\hline & 1. mēn. & 3. mēn. & 6. mēn. & 12. mēn. \\
\hline $\begin{array}{l}\text { Ir statistiski būtiskas atškirīibas starp } \\
\text { VLP un ĀFA grupu }\end{array}$ & jā & $n \overline{\mathrm{e}}$ & $n \overline{\mathrm{e}}$ & $\mathrm{ne \overline { }}$ \\
\hline p-vērtība (Mann-Whitney tests) & $\mathbf{0 , 0 0 7}$ & 0,594 & 0,519 & 0,826 \\
\hline p-vērtība (Kolmogorova-Smirnova tests) & $\mathbf{0 , 0 0 3}$ & 0,816 & 0,909 & 0,958 \\
\hline
\end{tabular}

P-vērtības sakrīt ar Asymp. Sig. (2-tailed) aprēkinu materiālos. Ja kolonnā kaut viena p-vērtība mazāka vai vienāda ar 0,05 , raksta “jā̄", pretējā gadījumā "nē".

Lai noskaidrotu, vai atslēgas tvēriena spēka Key Pinch mērījumi statistiski būtiski uzlabojas, ritot laikam pēc operācijas, tiek lietoti Wilcoxon Signed Ranks un Sign testi. Iegūti šādi rezultāti - abi testi rāda statistiski būtisku, monotonu atslēgas tvēriena spēka Key Pinch parametra uzlabojumu, ritot laikam pēc operācijas abās pētījumu grupās ( $p<0,05)$, bet ĀFA grupā starp 6. un 12. mēnesi statistiski būtisku uzlabojumu nekonstatē $(p>0,05)$ (sk. 3.25. tabulu).

3.25. tabula

Atslēgas tvēriena spēka Key Pinch mērījumi, lietojot Wilcoxon Signed Ranks un Sign testus

\begin{tabular}{|c|c|c|c|}
\hline & $\begin{array}{l}\text { 6. mēn. } \\
\text { pret 3. mēn. }\end{array}$ & $\begin{array}{l}\text { 12. mēn. } \\
\text { pret 6. mēn. }\end{array}$ & $\begin{array}{l}\text { 12. mēn. } \\
\text { pret 6. mēn. }\end{array}$ \\
\hline $\begin{array}{l}\text { Ir statistiski būtisks uzlabojums } \\
\text { (VLP grupa) }\end{array}$ & jā & jā & jā \\
\hline $\begin{array}{l}\text { Ir statistiski būtisks uzlabojums } \\
(\bar{A} F A \text { grupa })\end{array}$ & jā & jā & $\mathrm{ne}$ \\
\hline $\begin{array}{l}\text { p-vērtība (Wilcoxon Signed Ranks } \\
\text { tests) VLP grupai }\end{array}$ & $\mathbf{0 , 0 0 0}$ & $\mathbf{0 , 0 0 2}$ & 0,019 \\
\hline $\begin{array}{l}\text { p-vērtība (Sign tests) } \\
\text { VLP grupai }\end{array}$ & $\mathbf{0 , 0 0 0}$ & $\mathbf{0 , 0 1 8}$ & 0,063 \\
\hline $\begin{array}{l}\text { p-vērtība (Wilcoxon Signed Ranks } \\
\text { tests) ĀFA grupai }\end{array}$ & $\mathbf{0 , 0 0 0}$ & $\mathbf{0 , 0 0 0}$ & 0,262 \\
\hline p-vērtība (Sign tests) ĀFA grupai & $\mathbf{0 , 0 0 0}$ & 0,000 & 0,115 \\
\hline
\end{tabular}

P-vērtības sakrīt ar Asymp. Sig. (2-tailed) / 2 aprēḳinu materiālos. Ja kolonnā kaut viena p-vērtība mazāka vai vienāda ar 0,05 , raksta “jā", pretējā gadījumā "nē". 


\subsubsection{Trīs pirkstu tvēriena spēks Tripod Pinch}

Lietojot standarta statistiskas metodologiju trīs pirkstu tvēriena spēka Tripod Pinch vidējās vērtības noteikšanai atkarībā no manipulācijas veida un pagājušā laika intervāla pēc operācijas, ieguvām šādas vidējās vērtības (95 \% ticamības intervālus) (sk. 3.26. tabulu).

3.26. tabula

Trīs pirkstu tvēriena spēka Tripod Pinch vidējās vērtības

\begin{tabular}{|l|c|c|c|c|}
\cline { 2 - 5 } \multicolumn{1}{c|}{} & 1. mēn. & 3. mēn. & 6. mēn. & 12. mēn. \\
\hline VLP grupa, \% & $39,7 \pm 8,0$ & $74,6 \pm 5,3$ & $86,6 \pm 4,4$ & $92,1 \pm 2,7$ \\
\hline ĀFA grupa, \% & $26,2 \pm 6,4$ & $70,4 \pm 6,8$ & $86,7 \pm 4,0$ & $92,9 \pm 3,9$ \\
\hline
\end{tabular}

Aprēķina pēc formulas Mean \pm (Mean Upper Bound - Mean Lower Bound) / 2.

Mērījumu rezultātu vizualizācija skatāma 3.19. un 3.20. A, B, C, D attēlā.

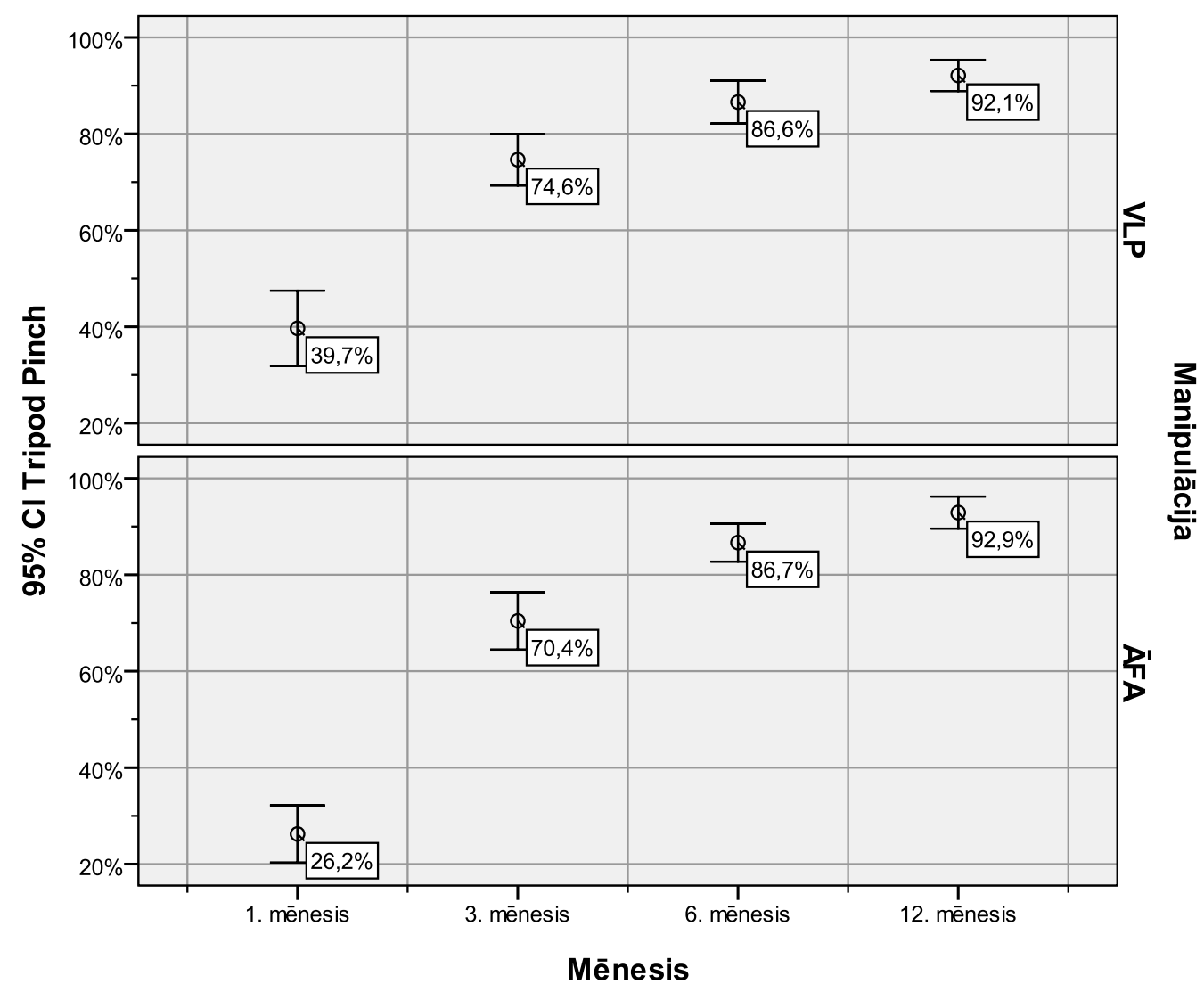

3.19. attēls. Plaukstas trīs pirkstu tvēriena spēka Tripod Pinch vērtības atkarībā no manipulācijas veida un pagājušā laika intervāla pēc operācijas 


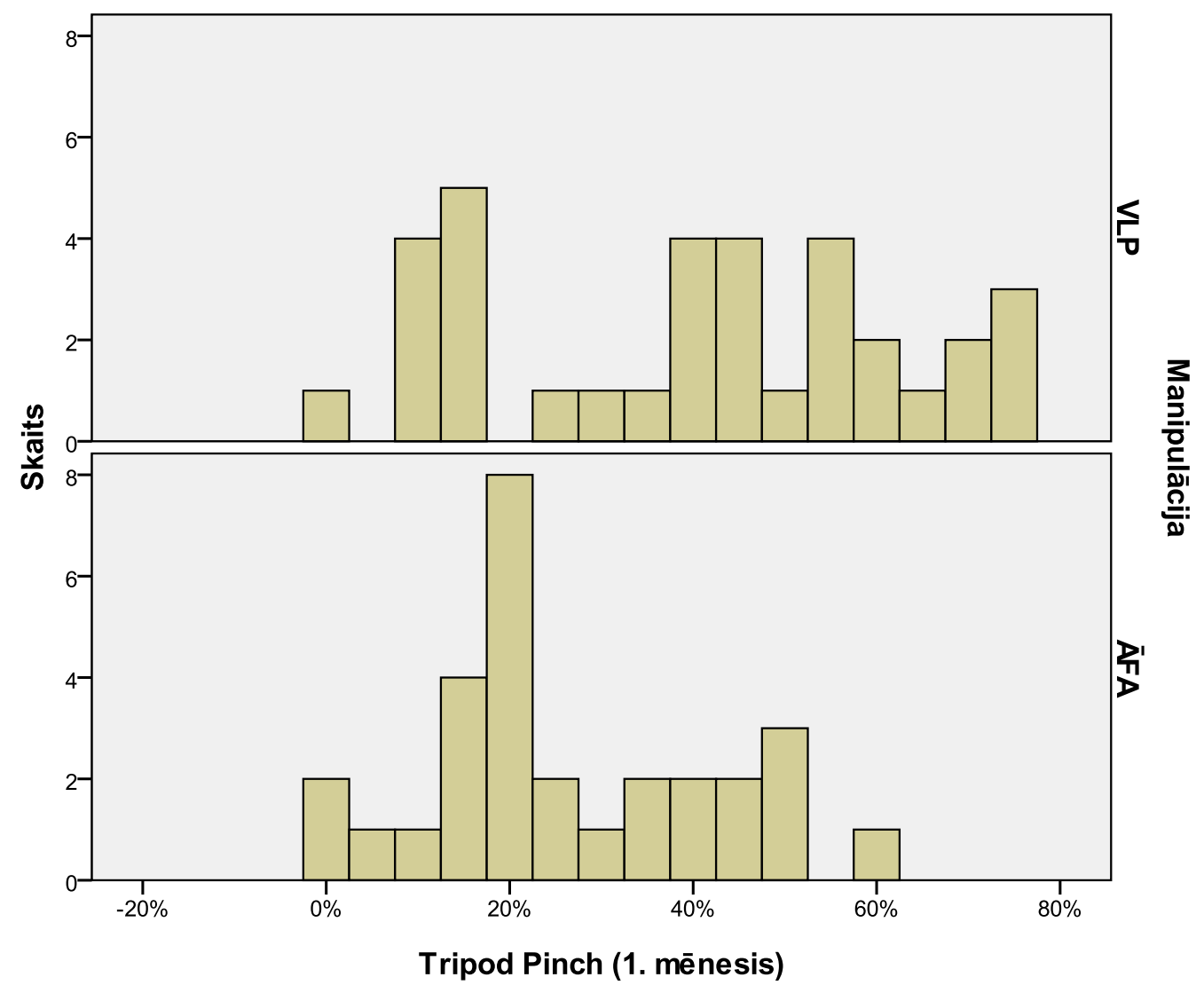

A

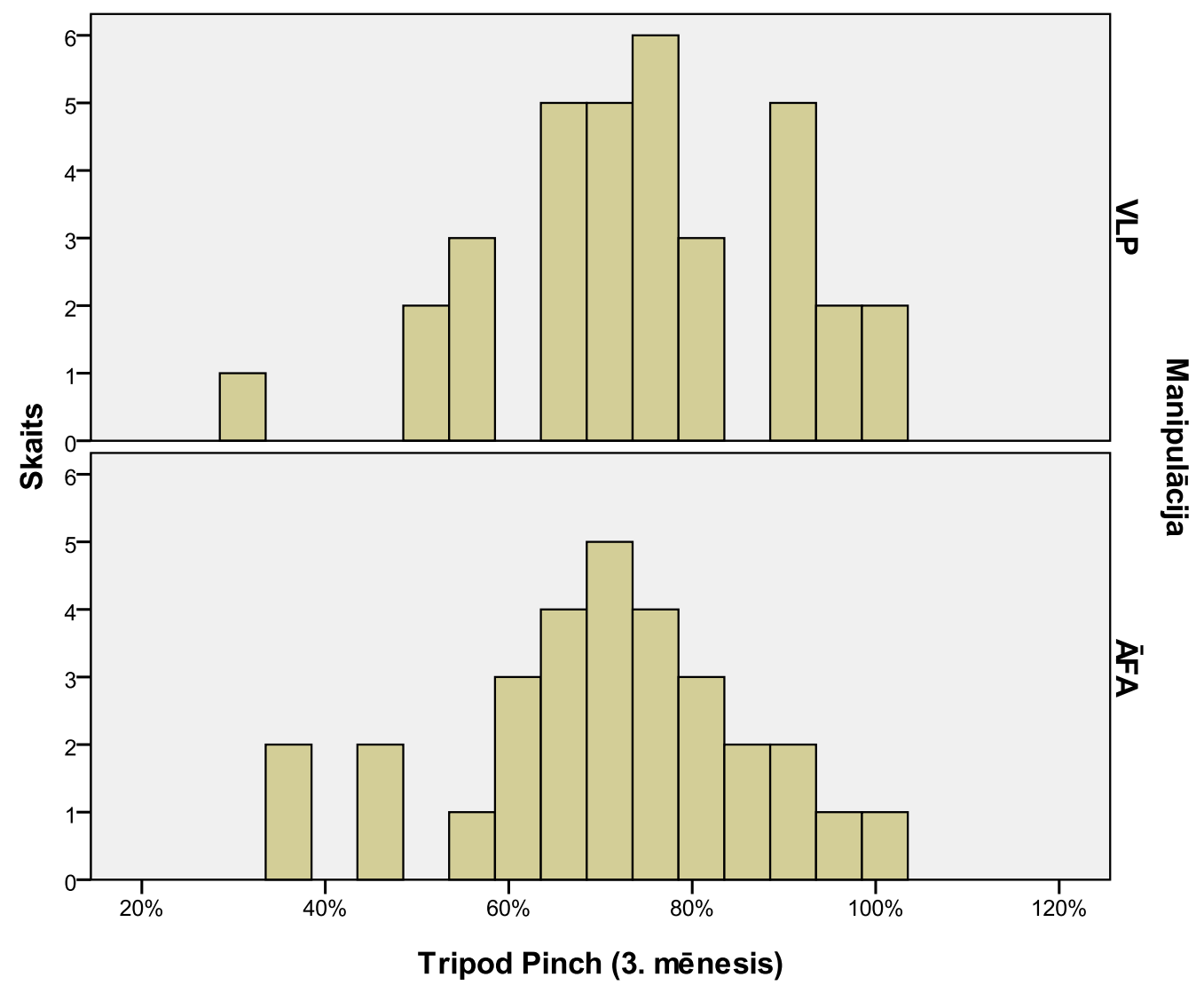




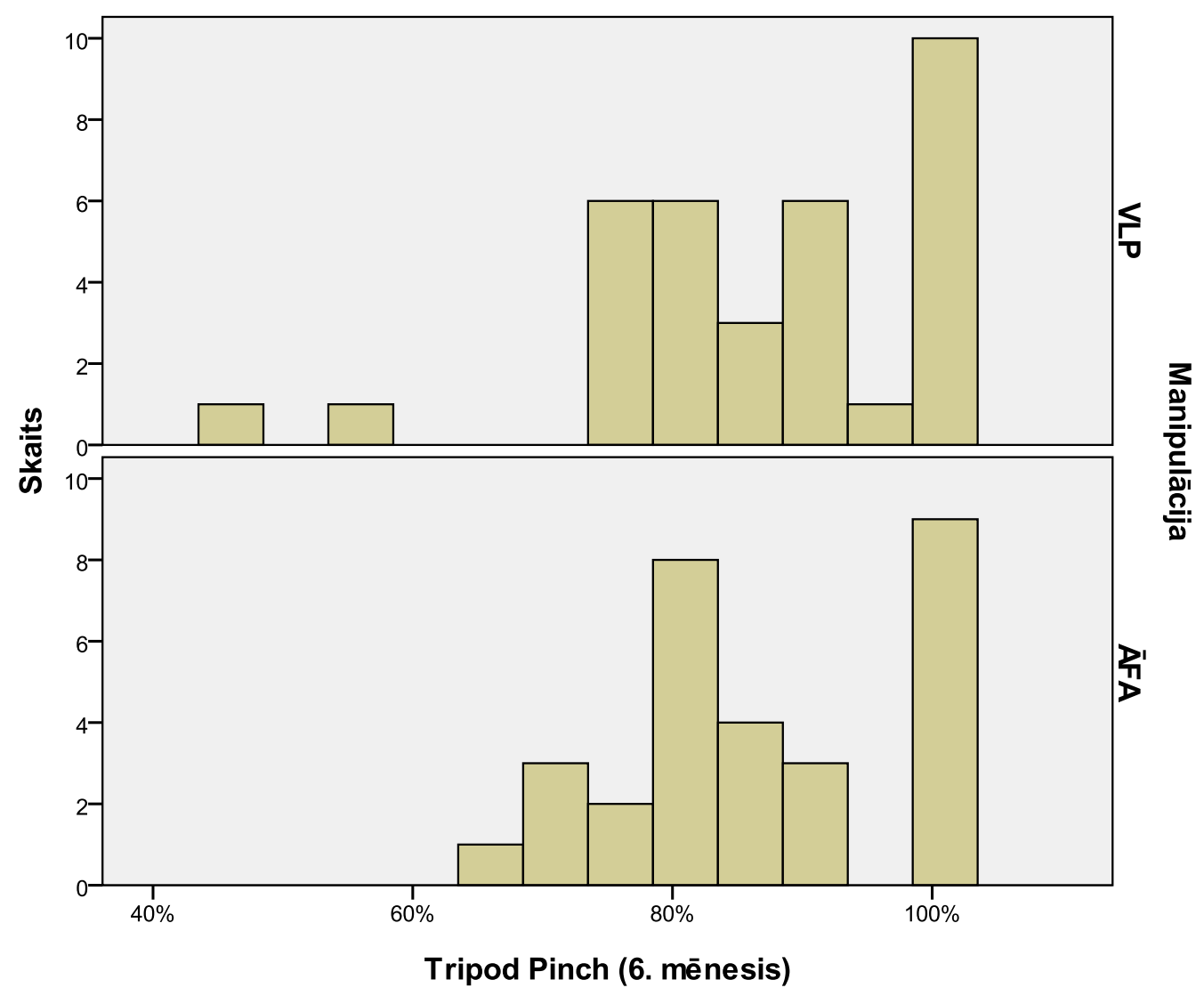

C

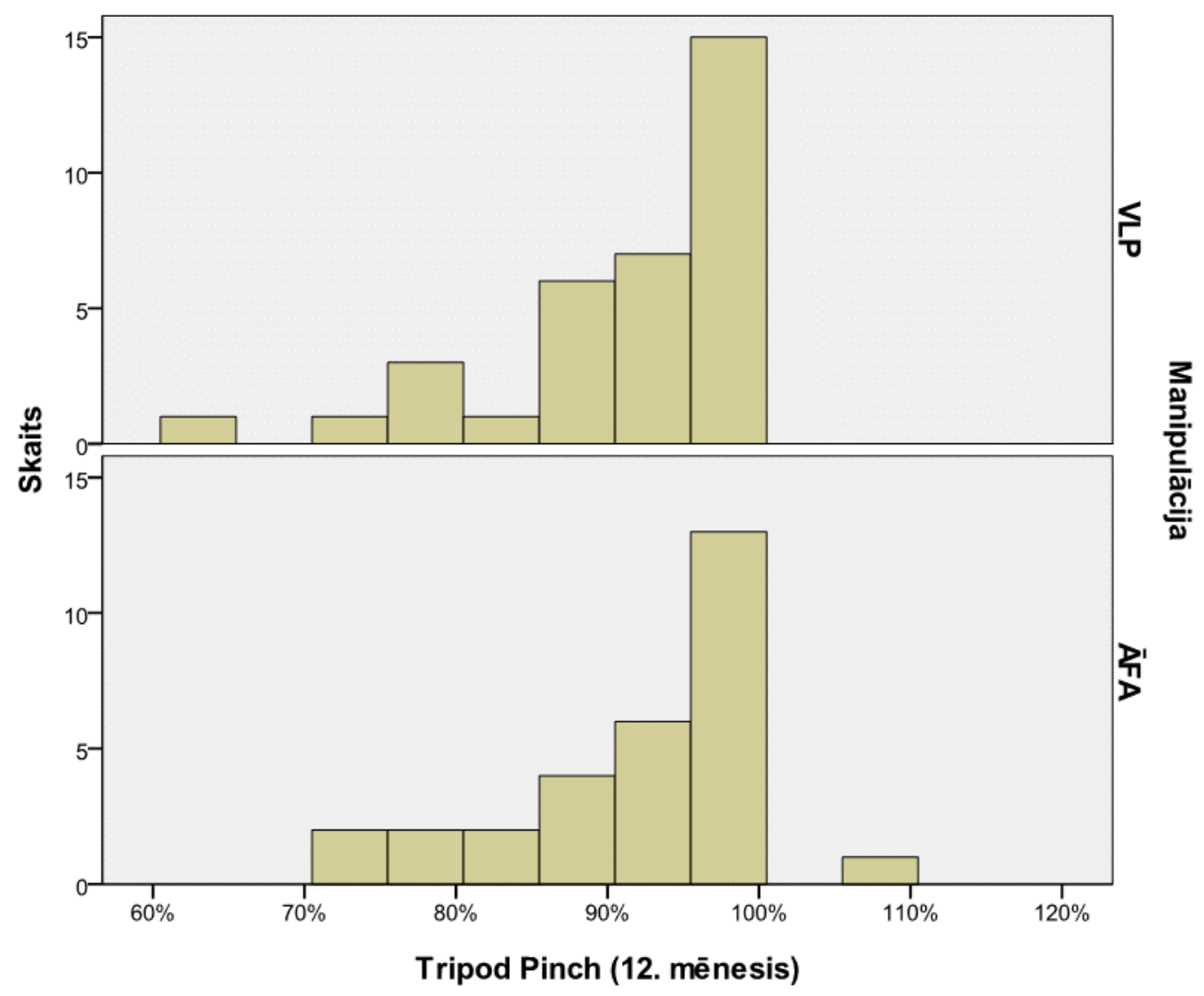

3.20. A, B, C, D attēls. Trīs pirkstu tvēriena spēka Tripod Pinch rezultāti dinamikā 
Lai analizētu, vai trīs pirkstu tvēriena spēka Tripod Pinch mērījumi statistiski būtiski atšķiras starp kontrolgrupām atkarībā no mēnešu skaita kopš operācijas, tika lietoti MannWhitney un Kolmogorova-Smirnova testi. Iegūti šãdi rezultāti - statistiski būtiskas atškirības trīs pirkstu tvēriena spēka Tripod Pinch parametra vērtībās atkarībā no manipulācijas veida sastopamas tikai 1. mēnesī ( $\mathrm{p}<0,05)$ (sk. 3.27. tabulu).

Trīs pirkstu tvēriena spēka Tripod Pinch mērījumi, lietojot Mann-Whitney un Kolmogorova-Smirnova testus

\begin{tabular}{|c|c|c|c|c|}
\hline & 1. mēn. & 3. mēn. & 6. mēn. & 12. mēn. \\
\hline $\begin{array}{l}\text { Ir statistiski būtiskas atškirīības starp } \\
\text { VLP un ĀFA grupu }\end{array}$ & jā & $n \bar{e}$ & $\mathrm{ne}$ & nē \\
\hline p-vērtîba (Mann-Whitney tests) & $\mathbf{0 , 0 3 1}$ & 0,306 & 0,790 & 0,711 \\
\hline p-vērtība (Kolmogorova-Smirnova tests) & $\mathbf{0 , 0 2 7}$ & 0,946 & 0,993 & 0,995 \\
\hline
\end{tabular}

P-vērtības sakrīt ar Asymp. Sig. (2-tailed) aprēkinu materiālos. Ja kolonnā kaut viena p-vērtība mazāka vai vienāda ar 0,05 , raksta “jā̄", pretējā gadījumā "nē".

Lai noskaidrotu, vai trīs pirkstu tvēriena spēka Tipod Pinch mērījumi statistiski būtiski uzlabojas, ritot laikam pēc operācijas, tiek lietoti Wilcoxon Signed Ranks un Sign testi. Iegūti šādi rezultāti - abi testi rāda statistiski būtisku, monotonu trīs pirkstu satvēriena spēka Tipod Pinch parametra uzlabojumu, ritot laikam pēc operācijas abās pētîjumu grupās $(\mathrm{p}<0,05)$ (sk. 3.28. tabulu).

3.28. tabula

Trīs pirkstu tvēriena spēka Tripod Pinch mērījumi, lietojot Wilcoxon Signed Ranks un Sign testus

\begin{tabular}{|c|c|c|c|}
\hline & $\begin{array}{l}\text { 3. mēn. } \\
\text { pret 1. mēn. }\end{array}$ & $\begin{array}{l}\text { 6. mēn } \\
\text { pret 3. mēn. }\end{array}$ & $\begin{array}{l}\text { 12. mēn } \\
\text { pret 6. mēn. }\end{array}$ \\
\hline $\begin{array}{l}\text { Ir statistiski būtisks uzlabojums } \\
\text { (VLP grupa) }\end{array}$ & jā & jā & $\mathrm{ja}$ \\
\hline $\begin{array}{l}\text { Ir statistiski būtisks uzlabojums } \\
\text { (ĀFA grupa) }\end{array}$ & $\mathrm{ja}$ & jā & $\mathrm{ja}$ \\
\hline $\begin{array}{l}\text { p-vērtība (Wilcoxon Signed } \\
\text { Ranks tests) VLP grupai }\end{array}$ & $\mathbf{0 , 0 0 0}$ & $\mathbf{0 , 0 0 0}$ & 0,005 \\
\hline p-vērtība (Sign tests) VLP grupai & $\mathbf{0 , 0 0 0}$ & $\mathbf{0 , 0 0 0}$ & 0,108 \\
\hline $\begin{array}{l}\text { p-vērtība (Wilcoxon Signed } \\
\text { Ranks tests) ĀFA grupai }\end{array}$ & $\mathbf{0 , 0 0 0}$ & $\mathbf{0 , 0 0 0}$ & 0,006 \\
\hline p-vērtība (Sign tests) ĀFA grupai & $\mathbf{0 , 0 0 0}$ & $\mathbf{0 , 0 0 0}$ & $\mathbf{0 , 0 1 7}$ \\
\hline
\end{tabular}

P-vērtības sakrīt ar Asymp. Sig. (2-tailed) / 2 aprēḳinu materiālos. Ja kolonnā kaut viena p-vērtība mazāka vai vienāda ar 0,05 , raksta "jā̄", pretējā gadījumā "nē". 


\subsection{Subjektīvās skalas}

\subsubsection{PRWE}

Lietojot standarta statistiskas metodolog̣iju PRWE vidējās vērtības noteikšanai atkarībā no manipulācijas veida un pagājušā laika intervāla pēc operācijas, ieguvām šādas vidējās vērtības (95\% ticamības intervālus) (sk. 3.29. tabulu).

PRWE vidējās vērtības

\begin{tabular}{|l|c|c|c|c|}
\cline { 2 - 5 } \multicolumn{1}{c|}{} & 1. mēn. & 3. mēn. & 6. mēn. & 12. mēn. \\
\hline VLP grupa, \% & $50,6 \pm 8,0$ & $13,5 \pm 5,3$ & $7,2 \pm 4,4$ & $2,1 \pm 2,7$ \\
\hline ĀFA grupa, \% & $77,8 \pm 6,4$ & $21,2 \pm 6,8$ & $9,4 \pm 4,0$ & $3,9 \pm 3,9$ \\
\hline
\end{tabular}

Aprēḳina pēc formulas Mean \pm (Mean Upper Bound -Mean Lower Bound) / 2.

Mērījumu rezultātu vizualizācija skatāma 3.21. un 3.22. A, B, C, D attēlā.

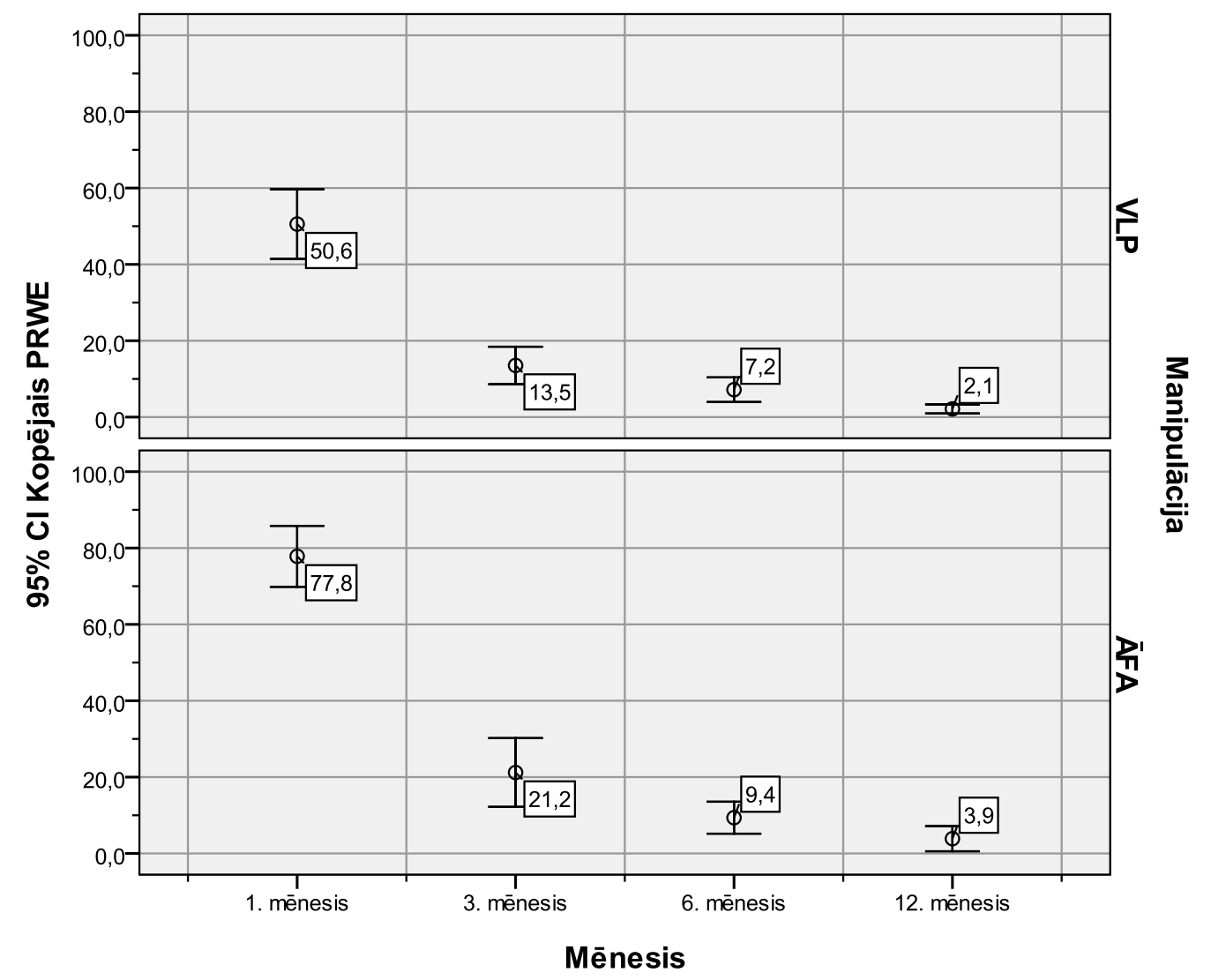

3.21. attēls. PRWE vērtības atkarībā no manipulācijas veida un pagājušā laika intervāla pēc operācijas 


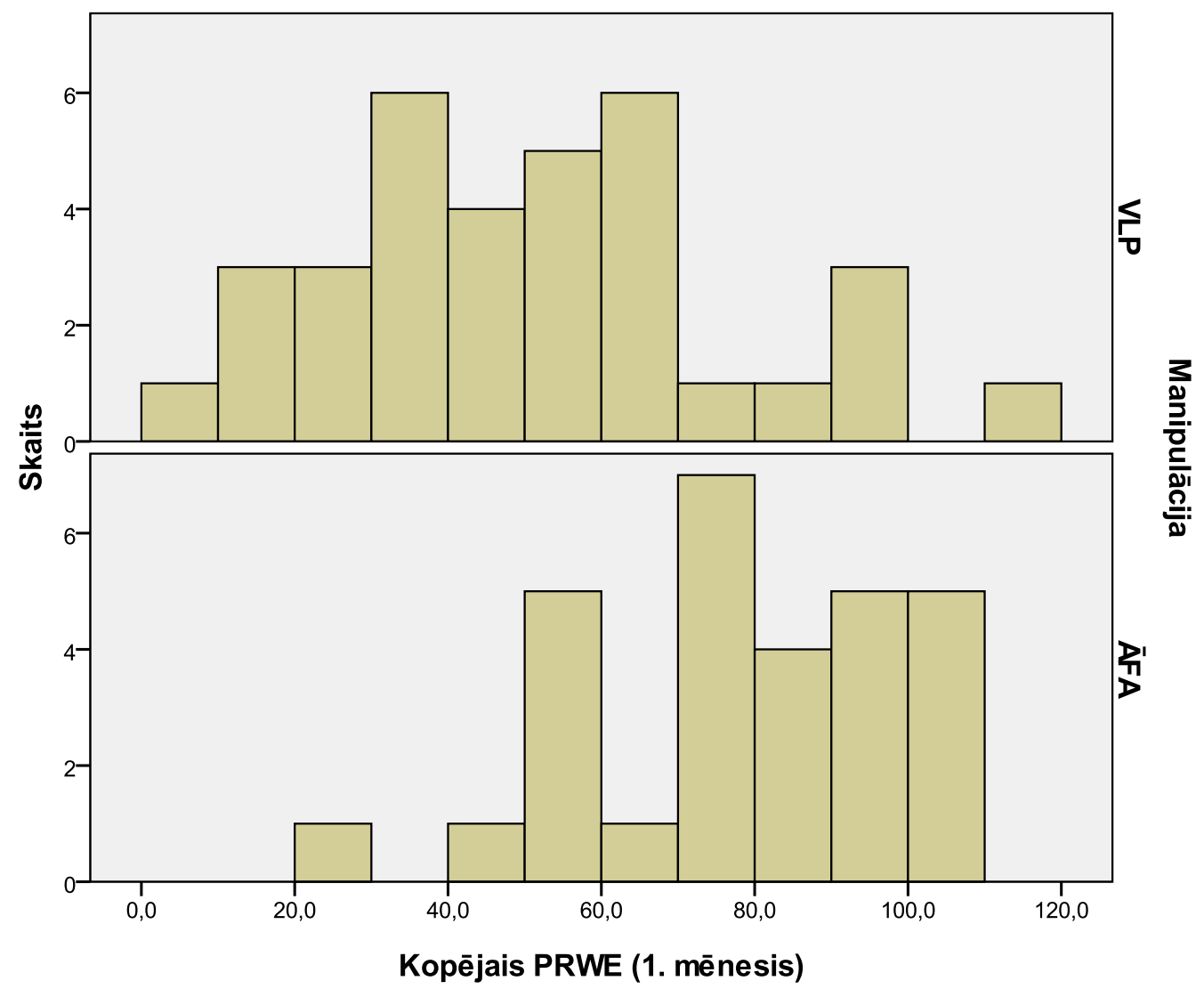

A

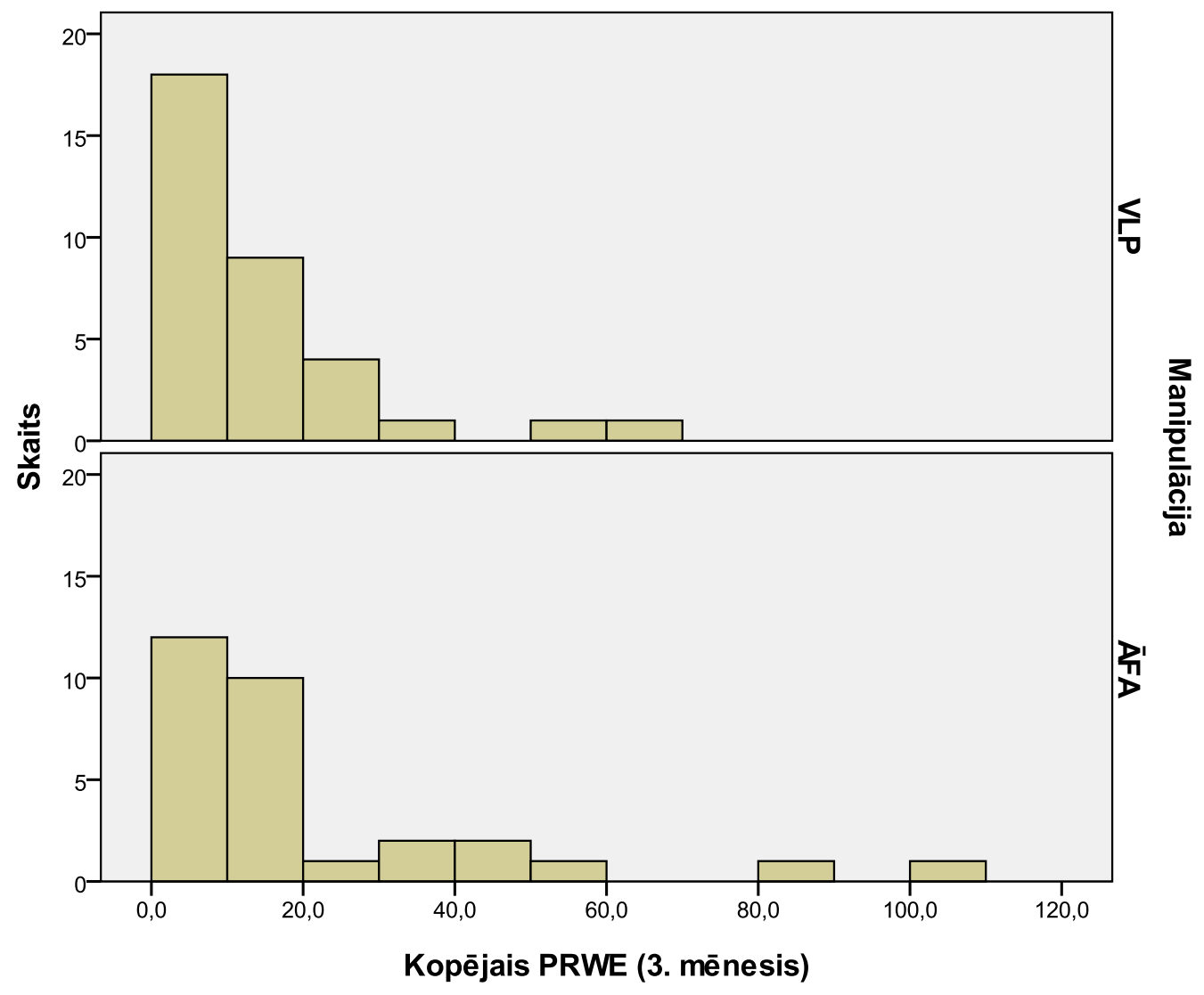




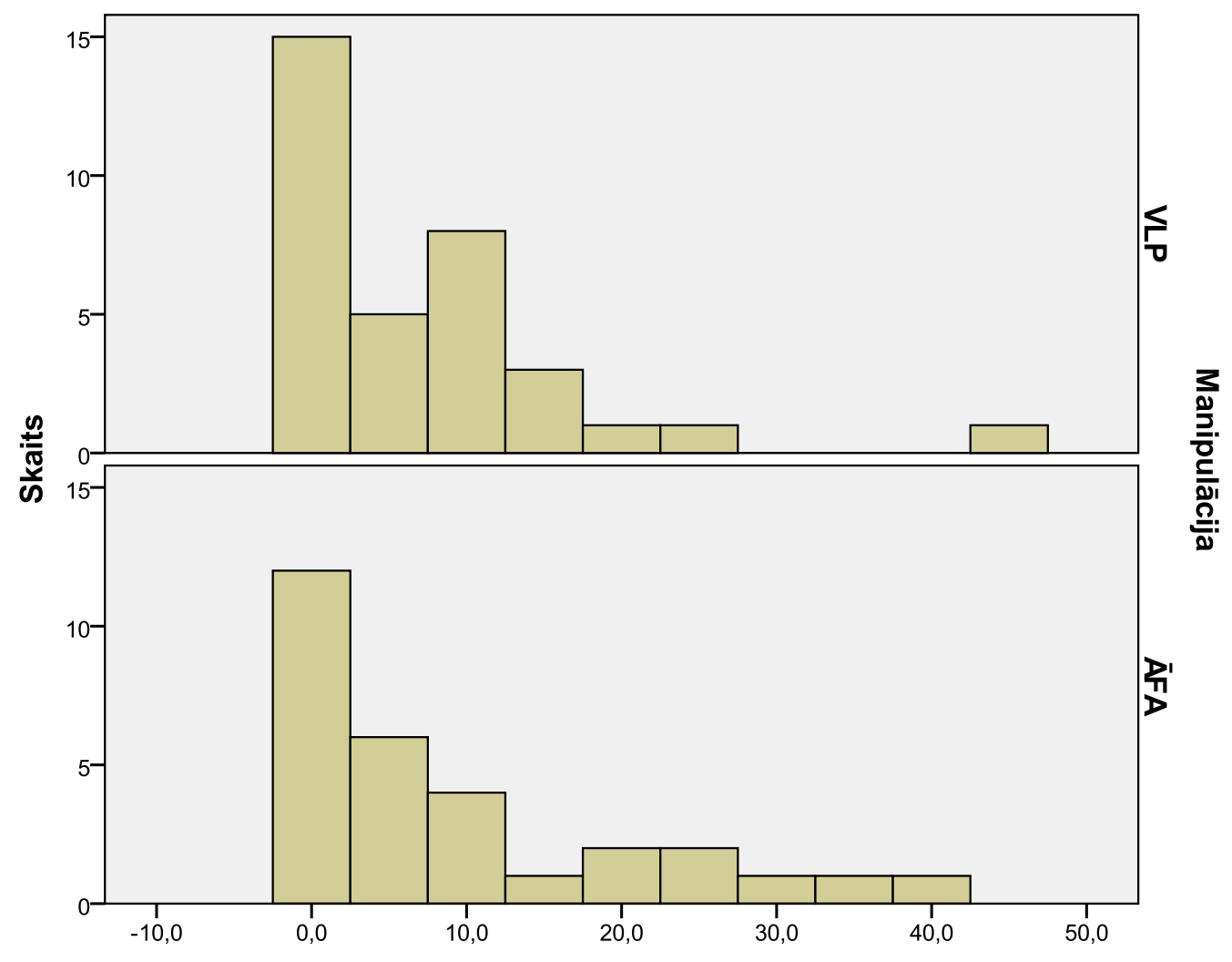

$\mathbf{C}$

Kopējais PRWE (6. mēnesis)

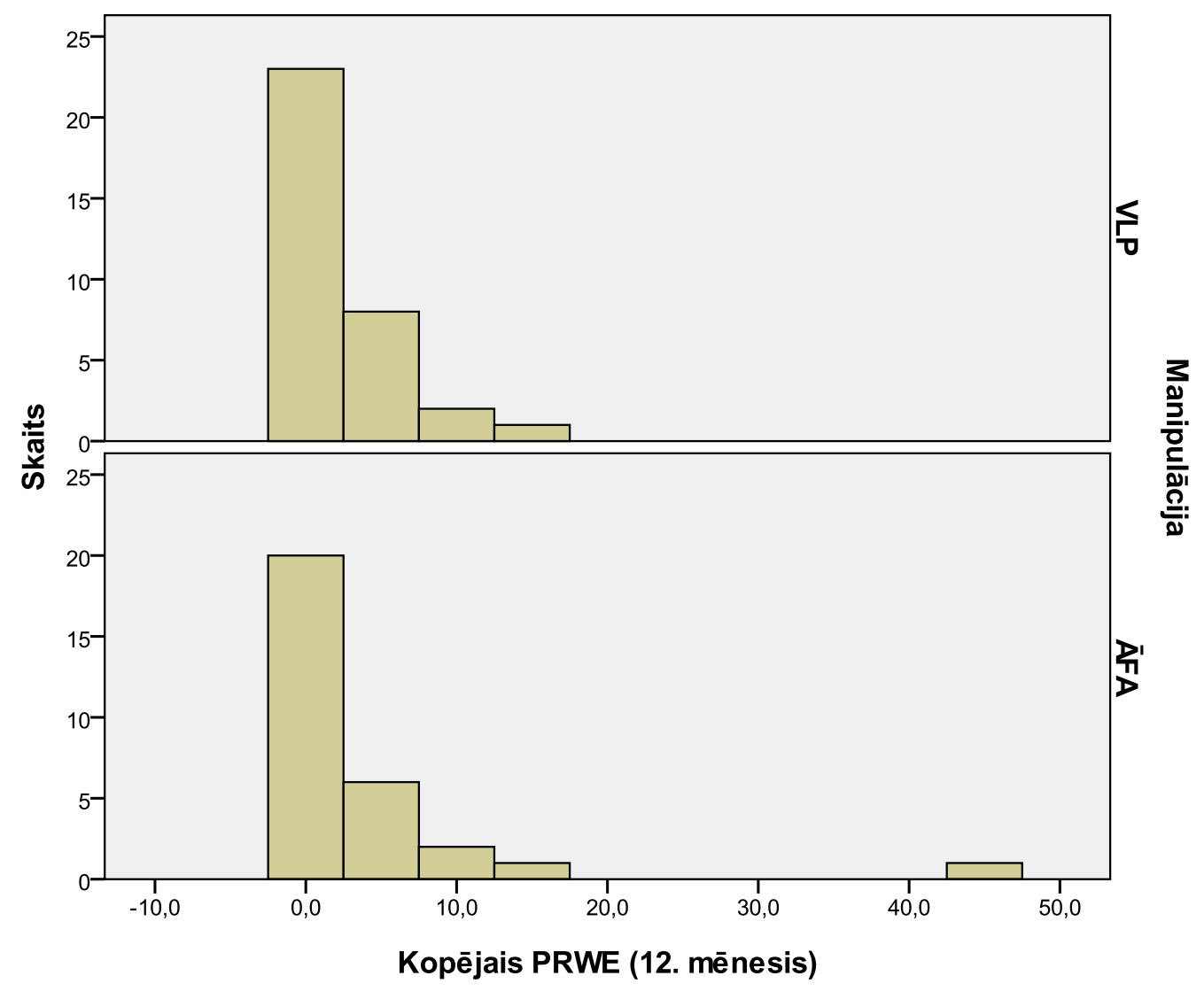

3.22. A, B, C, D attēls. PRWE vērtējuma rezultāti dinamikā 
Lai analizētu, vai PRWE vērtību mērījumi statistiski būtiski atšķiras starp kontrolgrupām atkarībā no mēnešu skaita kopš operācijas, tika lietoti Mann-Whitney un Kolmogorova-Smirnova testi. Iegūti šādi rezultāti - statistiski būtiskas atšķirības PRWE parametra vērtībās atkarībā no manipulācijas veida sastopamas tikai 1 . mēnesī $(p<0,01)$ (sk. 3.30. tabulu).

PRWE mērījumi, lietojot Mann-Whitney un Kolmogorova-Smirnova testus

\begin{tabular}{|l|c|c|c|c|}
\cline { 2 - 5 } \multicolumn{1}{c|}{} & $\mathbf{1 . ~ m e ̄ n . ~}$ & 3. mēn. & 6. mēn. & 12. mēn. \\
\hline $\begin{array}{l}\text { Ir statistiski būtiskas atšǩirīibas starp } \\
\text { VLP un ĀFA grupu }\end{array}$ & jā & $n \bar{e}$ & $n \bar{e}$ & $n \bar{e}$ \\
\hline p-vērtība (Mann-Whitney tests) & $\mathbf{0 , 0 0 0}$ & 0,249 & 0,490 & 0,320 \\
\hline p-vērtíba (Kolmogorova-Smirnova tests) & $\mathbf{0 , 0 0 0}$ & 0,717 & 0,717 & 0,816 \\
\hline
\end{tabular}

P-vērtības sakrīt ar Asymp. Sig. (2-tailed) aprēkinu materiālos. Ja kolonnā kaut viena p-vērtība mazāka vai vienāda ar 0,05 , raksta "jā̄", pretējā gadījumā "nē".

Lai noskaidrotu, vai PRWE vērtību mērījumi statistiski būtiski uzlabojas (samazinās), ritot laikam pēc operācijas, tiek lietoti Wilcoxon Signed Ranks un Sign testi. Iegūti šādi rezultāti - abi testi rāda statistiski būtisku, monotonu plaukstas PRWE vērtības parametra uzlabojumu (samazinājumu), ritot laikam pēc operācijas abās pētījumu grupās $(p<0,05)$ (sk. 3.31. tabulu).

PRWE mērījumi, lietojot Wilcoxon Signed Ranks un Sign testus

\begin{tabular}{|c|c|c|c|}
\hline & $\begin{array}{c}\text { 3. mēn. } \\
\text { pret } 1 . \text { mēn. }\end{array}$ & $\begin{array}{l}\text { 6. mēn. } \\
\text { pret 3. mēn. }\end{array}$ & $\begin{array}{l}\text { 12. mēn. } \\
\text { pret } 6 . \text { mēn. }\end{array}$ \\
\hline $\begin{array}{l}\text { Ir statistiski būtisks uzlabojums } \\
\text { (VLP grupa) }\end{array}$ & jā & $\mathrm{jā}$ & $\mathrm{ja}$ \\
\hline $\begin{array}{l}\text { Ir statistiski būtisks uzlabojums } \\
\text { (ĀFA grupa) }\end{array}$ & jā & $\mathrm{jā}$ & jā \\
\hline $\begin{array}{l}\text { p-vērtība (Wilcoxon Signed Ranks } \\
\text { tests) VLP grupai }\end{array}$ & $\mathbf{0 , 0 0 0}$ & $\mathbf{0 , 0 0 9}$ & $\mathbf{0 , 0 0 0}$ \\
\hline p-vērtība (Sign tests) VLP grupai & $\mathbf{0 , 0 0 0}$ & $\mathbf{0 , 0 1 2}$ & $\mathbf{0 , 0 0 0}$ \\
\hline $\begin{array}{l}\text { p-vērtība (Wilcoxon Signed Ranks } \\
\text { tests) ĀFA grupai }\end{array}$ & $\mathbf{0 , 0 0 0}$ & $\mathbf{0 , 0 0 1}$ & $\mathbf{0 , 0 0 3}$ \\
\hline p-vērtība (Sign tests) ĀFA grupai & $\mathbf{0 , 0 0 0}$ & 0,009 & $\mathbf{0 , 0 0 1}$ \\
\hline
\end{tabular}

P-vērtības sakrīt ar Asymp. Sig. (2-tailed) / 2 aprēḳinu materiālos. Ja kolonnā kaut viena p-vērtība mazāka vai vienāda ar 0,05 , raksta "jā", pretējā gadījumā "nē".

Ṇemot vērā faktu, ka abās pētāmajās grupās bija dažāda vecuma pacienti un PRWE anketā ir iekḷautas daudzveidīgu aktivitāšu ierobežojuma pakāpes un sāpju subjektīvā novērtēšana, tika noskaidrots, vai pastāv korelācija starp pacienta vecumu un subjektīvo vērtējumu (sk. 3.23. attēlu). Standarta korelācijas analīze neuzrāda statistiski būtisku kopējā PRWE vērtību atkarību no pacienta vecuma nevienā no datu reǵistrēšanas reizēm $(p>0,05)$. 


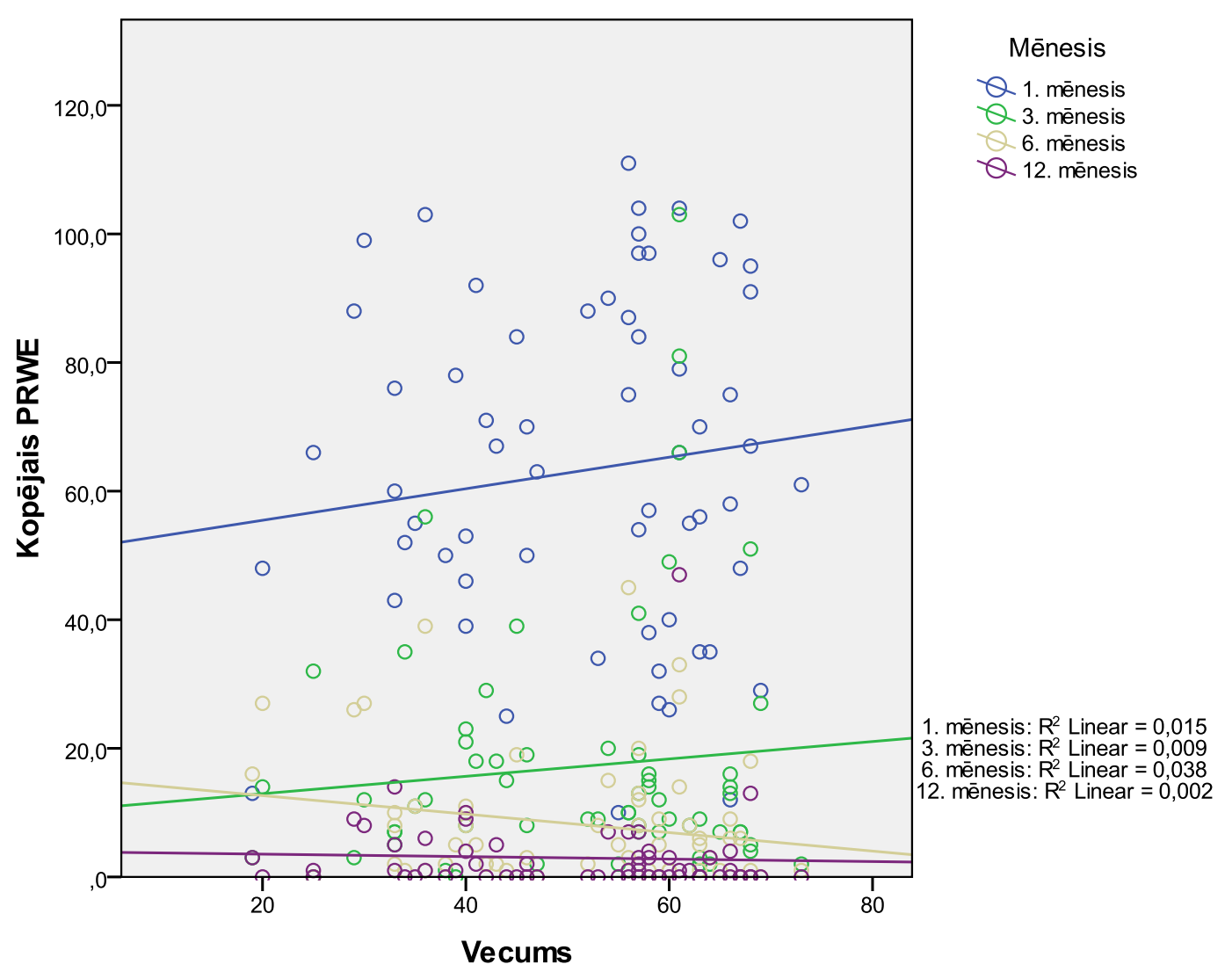

3.23. attēls. Korelācija starp PRWE parametra vērtībām un pacienta vecumu

\subsubsection{MASS07}

Lietojot standarta statistiskas metodolog̣iju MASS07 skalas vidējās vērtības noteikšanai atkarībā no manipulācijas veida un pagājušā laika intervāla pēc operācijas, ieguvām šādas vidējās vērtības (95 \% ticamības intervālus) (sk. 3.32. tabulu).

3.32. tabula

\section{MASS07 skalas vidējās vērtības}

\begin{tabular}{|l|c|c|c|c|}
\cline { 2 - 5 } \multicolumn{1}{c|}{} & 1. mēn. & 3. mēn. & 6. mēn. & 12. mēn. \\
\hline VLP grupa, \% & $27,9 \pm 9,1$ & $5,1 \pm 2,8$ & $1,4 \pm 1,4$ & $0,3 \pm 0,3$ \\
\hline ĀFA grupa, \% & $58,1 \pm 11,4$ & $8,8 \pm 6,6$ & $2,1 \pm 1,8$ & $0,9 \pm 0,9$ \\
\hline
\end{tabular}

Aprēķina pēc formulas Mean \pm (Mean Upper Bound - Mean Lower Bound) / 2. 
Mērījumu rezultātu vizualizācija skatāma 3.24. un 3.25. A, B, C, D attēlā.

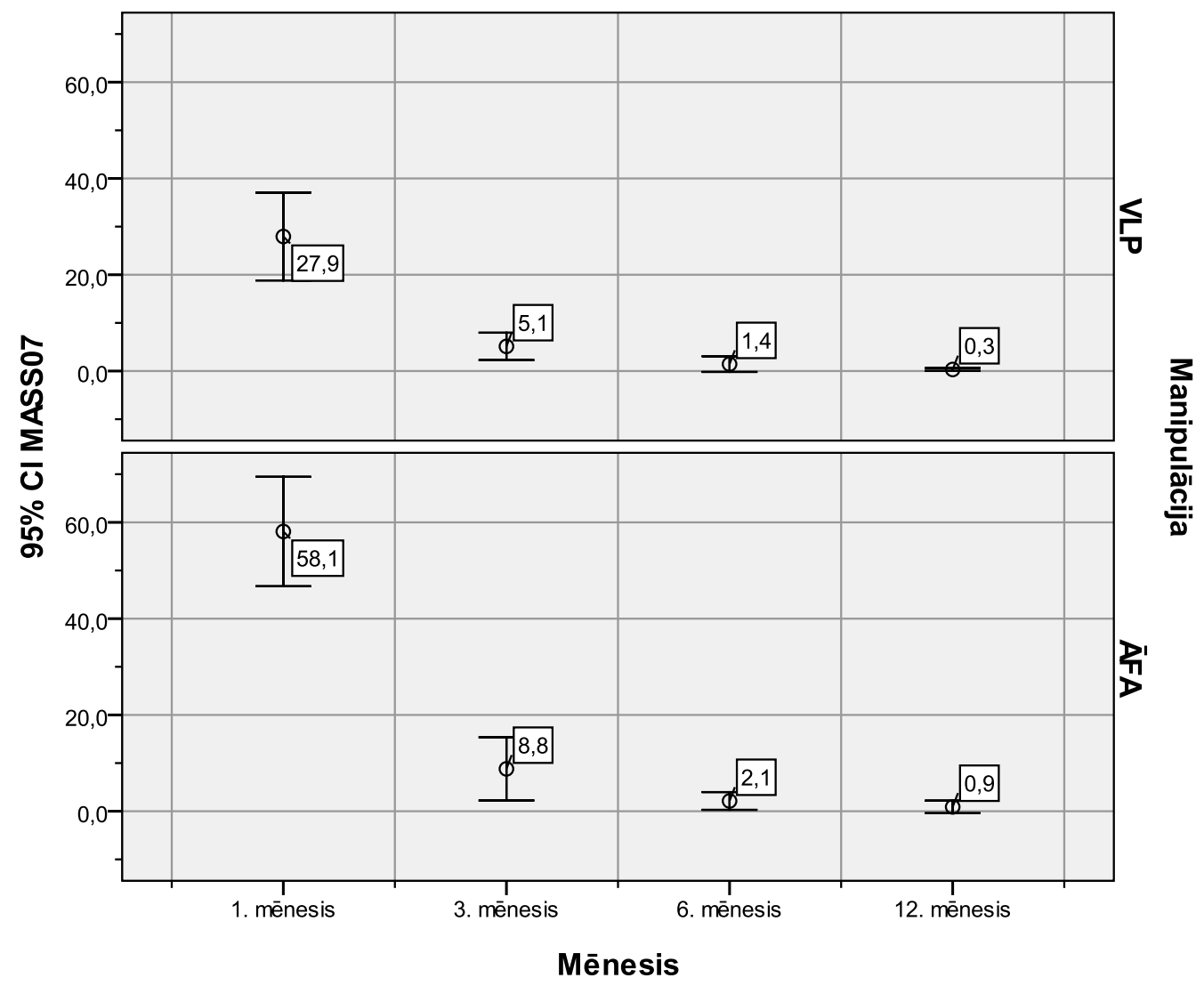

3.24. attēls. MASS07 vērtības atkarībā no manipulācijas veida un pagājušā laika intervāla pēc operācijas

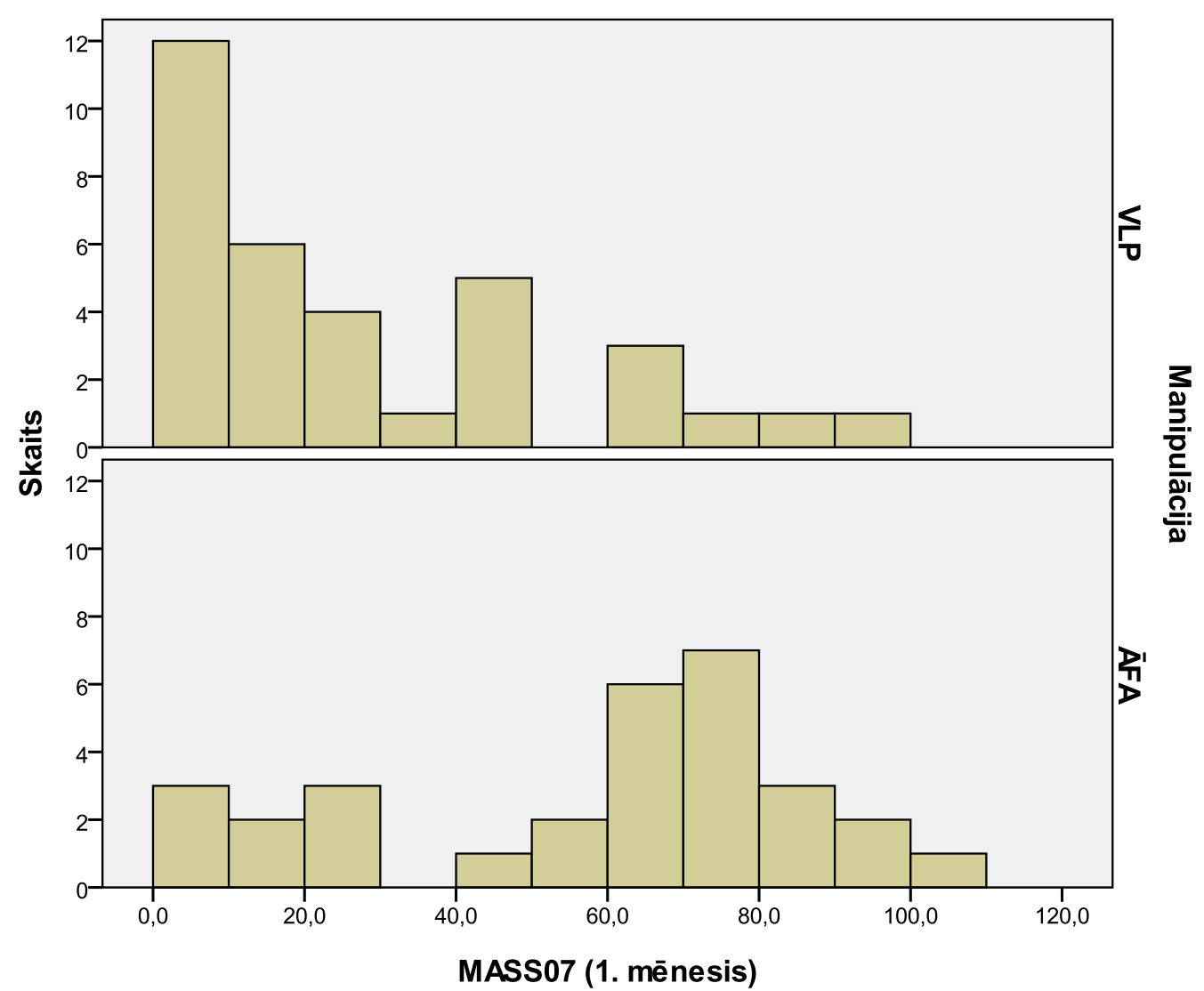




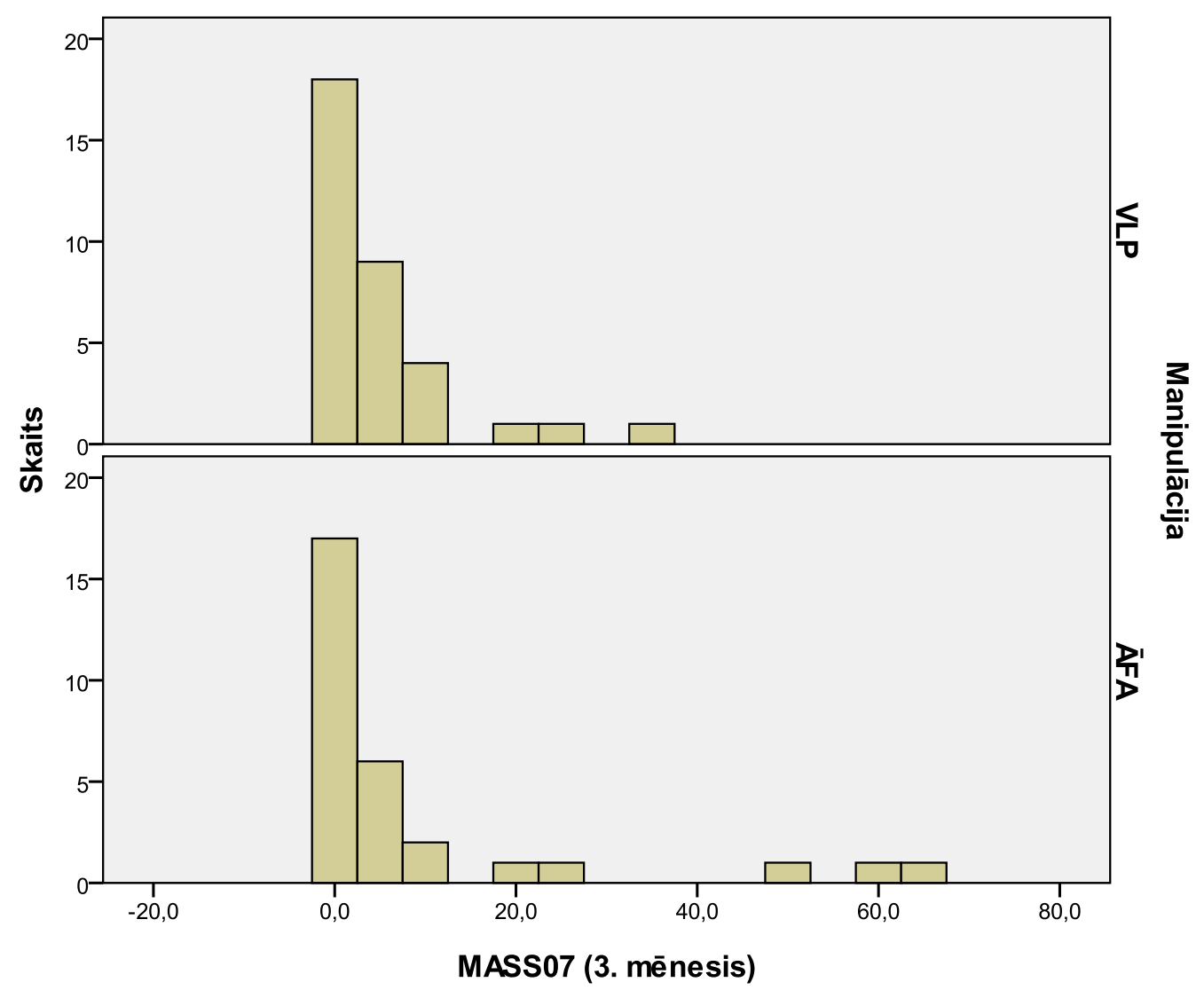

B

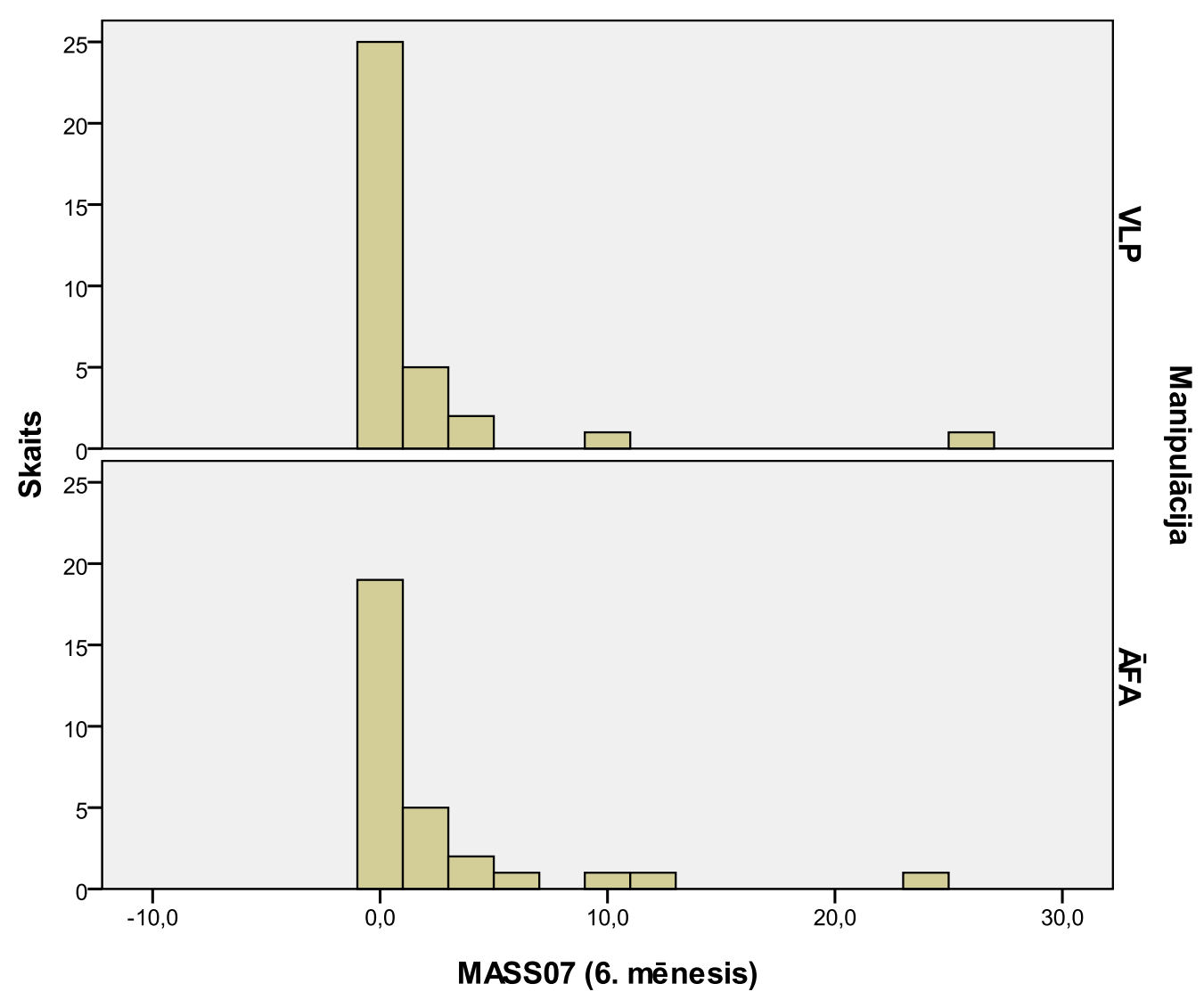




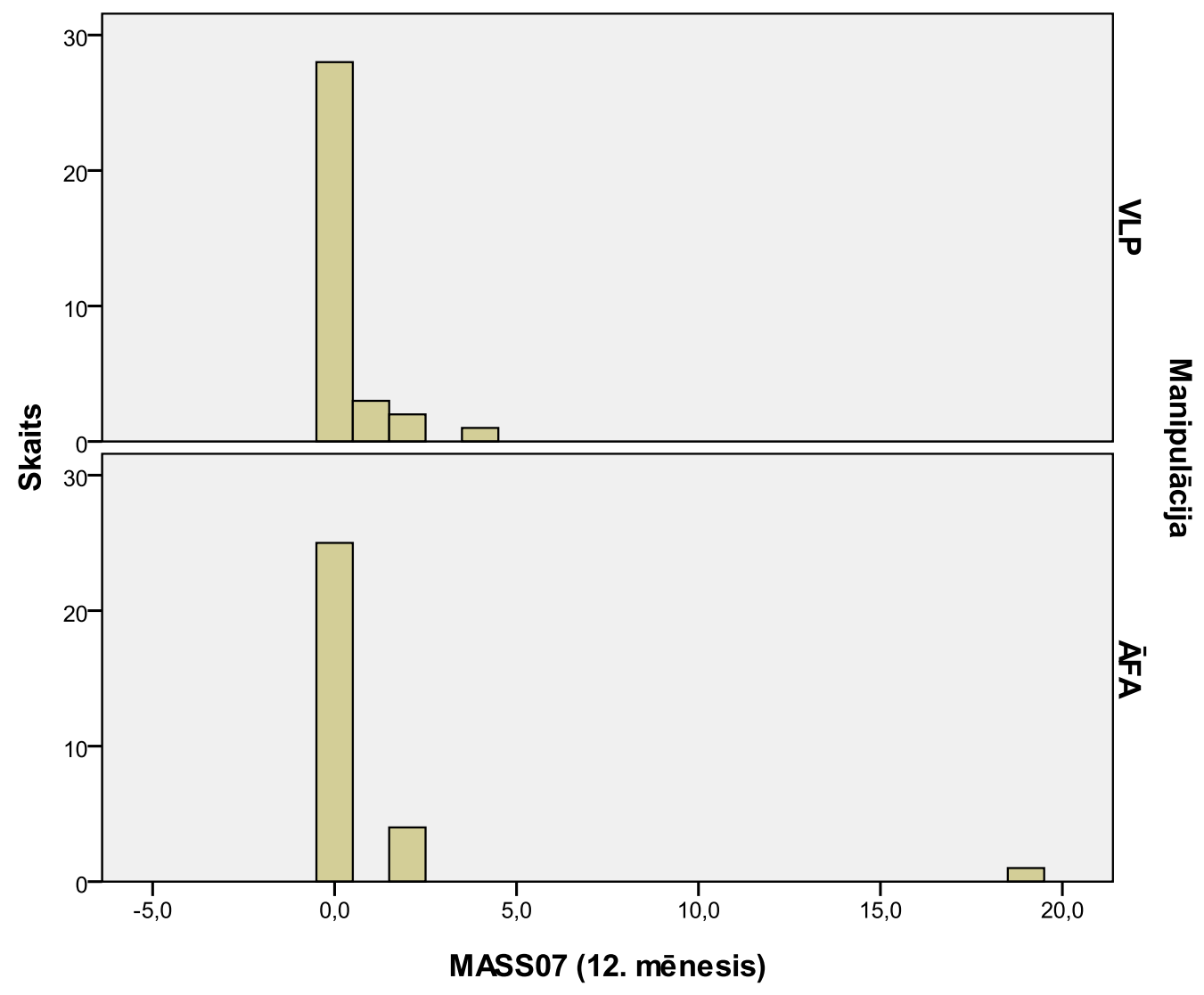

3.25. A, B, C, D attēls. PRWE vērtējuma rezultāti dinamikā

Lai analizētu, vai MASS07 skalas vērtību mērījumi statistiski būtiski atšķiras starp kontrolgrupām atkarībā no mēnešu skaita kopš operācijas, tika lietoti Mann-Whitney un Kolmogorova-Smirnova testi. Iegūti šādi rezultāti - statistiski būtiskas atšḳirības MASS07 skalas parametra vērtībās atkarībā no manipulācijas veida sastopamas tikai 1. mēnes̄̄ (p < 0,01) (sk. 3.33. tabulu).

3.33. tabula

\section{MASS07 skalas vērtību mērījumi, lietojot Mann-Whitney un Kolmogorova-Smirnova testus}

\begin{tabular}{|l|c|c|c|c|}
\cline { 2 - 5 } \multicolumn{1}{c|}{} & 1. mēn. & 3. mēn. & 6. mēn. & 12. mēn. \\
\hline $\begin{array}{l}\text { Ir statistiski būtiskas atšķirīibas starp } \\
\text { VLP un ĀFA grupu }\end{array}$ & jā & $n \bar{e}$ & $n \bar{e}$ & nē \\
\hline p-vērtība (Mann-Whitney tests) & $\mathbf{0 , 0 0 0}$ & 0,887 & 0,376 & 0,967 \\
\hline p-vērtíba (Kolmogorova-Smirnova tests) & $\mathbf{0 , 0 0 0}$ & 0,997 & 0,993 & 1,000 \\
\hline
\end{tabular}

P-vērtības sakrīt ar Asymp. Sig. (2-tailed) aprēḳinu materiālos. Ja kolonnā kaut viena p-vērtība mazāka vai vienāda ar 0,05 , raksta "jā", pretējā gadījumā "nē".

Lai noskaidrotu, vai MASS07 skalas vērtību mērījumi statistiski būtiski uzlabojas (samazinās), ritot laikam pēc operācijas, tiek lietoti Wilcoxon Signed Ranks un Sign testi. Iegūti šādi rezultāti - abi testi rāda statistiski būtisku, monotonu plaukstas MASS07 vērtības parametra uzlabojumu (samazinājumu), ritot laikam pēc operācijas abās pētījumu grupās 
( $\mathrm{p}<0,05$ ), bet ĀFA grupā 12. mēnesī, salīdzinot ar 6. mēnesi, uzlabojums vairs nav statistiski būtisks (sk. 3.34. tabulu).

3.34. tabula

MASS07 skalas vērtību mērījumi, lietojot Wilcoxon Signed Ranks un Sign testus

\begin{tabular}{|l|c|c|c|}
\cline { 2 - 4 } \multicolumn{1}{c|}{} & $\begin{array}{c}\text { 3. mēn. } \\
\text { pret 1. mēn. }\end{array}$ & $\begin{array}{c}\mathbf{6} \text {. mēn. } \\
\text { pret 3. mēn. }\end{array}$ & $\begin{array}{c}\text { 12. mēn. } \\
\text { pret 6. mēn. }\end{array}$ \\
\hline $\begin{array}{l}\text { Ir statistiski būtisks uzlabojums } \\
\text { (VLPP grupa) }\end{array}$ & jā & $j \bar{a}$ & jā \\
\hline $\begin{array}{l}\text { Ir statistiski būtisks uzlabojums } \\
\text { (ĀFA grupa) }\end{array}$ & jā & jā & nē \\
\hline $\begin{array}{l}\text { p-vērtība (Wilcoxon Signed } \\
\text { Ranks tests) VLP grupai }\end{array}$ & $\mathbf{0 , 0 0 0}$ & $\mathbf{0 , 0 0 3}$ & $\mathbf{0 , 0 3 1}$ \\
\hline p-vērtība (Sign tests) VLP grupai & $\mathbf{0 , 0 0 0}$ & $\mathbf{0 , 0 0 7}$ & 0,227 \\
\hline $\begin{array}{l}\text { p-vērtība (Wilcoxon Signed } \\
\text { Ranks tests) ĀFA grupai }\end{array}$ & $\mathbf{0 , 0 0 0}$ & $\mathbf{0 , 0 0 4}$ & 0,106 \\
\hline p-vērtība (Sign tests) ĀFA grupai & $\mathbf{0 , 0 0 0}$ & $\mathbf{0 , 0 0 7}$ & 0,146 \\
\hline
\end{tabular}

P-vērtības sakrīt ar Asymp. Sig. (2-tailed) / 2 aprēķinu materiālos. Ja kolonnā kaut viena p-vērtība mazāka vai vienāda ar 0,05 , raksta "jā", pretējā gadījumā "nē".

\subsubsection{Gartland and Werley modificētā skala}

Lietojot standarta statistiskas metodologijiju Gartland and Werley skalas vidējās vērtības noteikšanai atkarībā no manipulācijas veida un pagājušã laika intervāla pēc operācijas, ieguvām šādas vidējās vērtības (95 \% ticamības intervālus) (sk. 3.35. tabulu).

3.35. tabula

Gartland and Werley skalas vidējās vērtības

\begin{tabular}{|l|c|c|c|c|}
\cline { 2 - 5 } \multicolumn{1}{c|}{} & 1. mēn. & 3. mēn. & 6. mēn. & 12. mēn. \\
\hline VLP grupa, \% & $58,9 \pm 3,9$ & $78,1 \pm 2,9$ & $85,3 \pm 2,9$ & $91,8 \pm 2,9$ \\
\hline ĀFA grupa, \% & $47,9 \pm 3,0$ & $72,8 \pm 3,6$ & $82,8 \pm 3,2$ & $88,5 \pm 3,8$ \\
\hline
\end{tabular}

Aprēḳina pēc formulas Mean \pm (Mean Upper Bound - Mean Lower Bound) / 2. 
Mērījumu rezultātu vizualizācija skatāma 3.26. un 3.27. A, B, C, D attēlā.

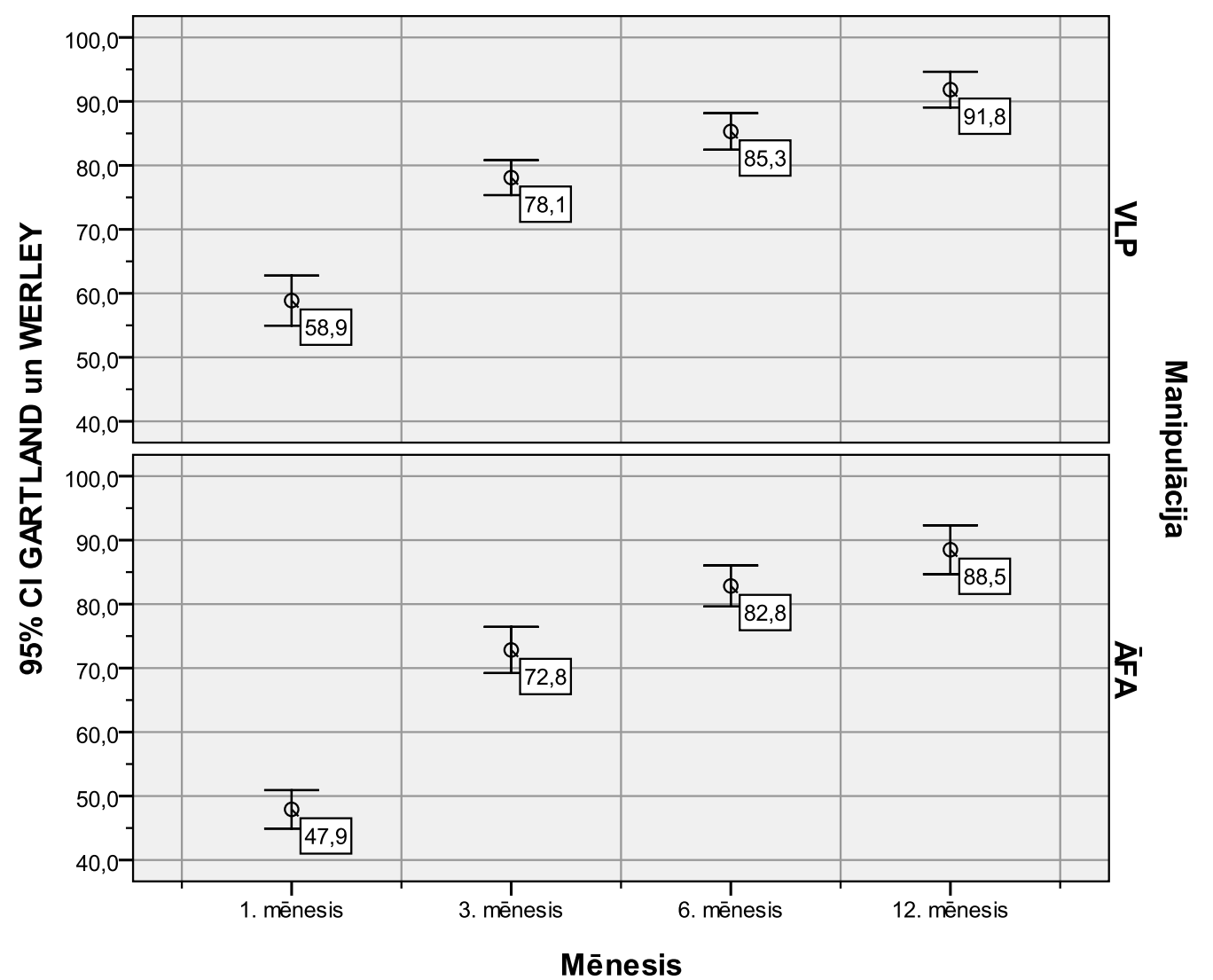

3.26. attēls. Gartland and Werley skalas vērtības atkarībā no manipulācijas veida un pagājušā laika intervāla pēc operācijas

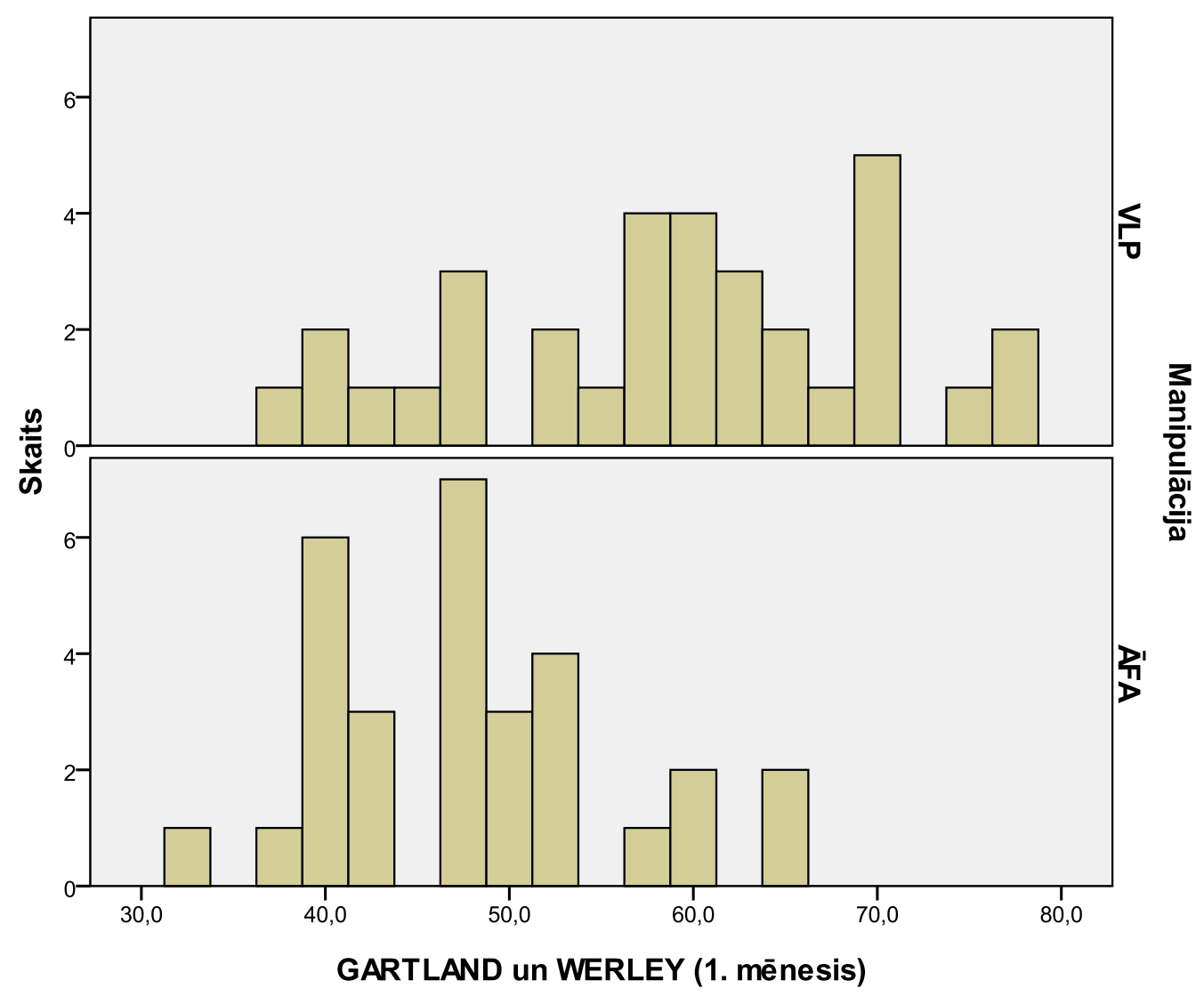



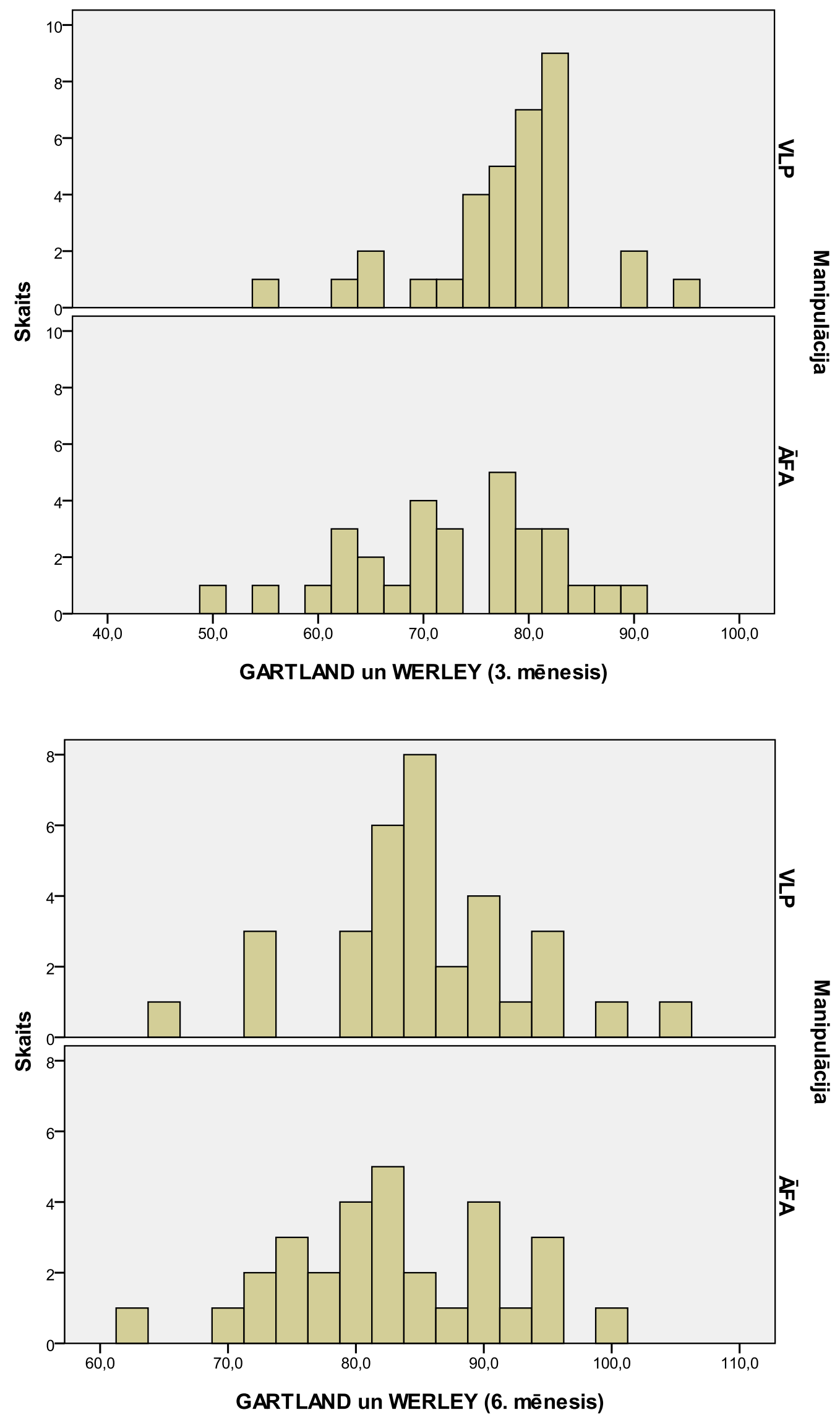


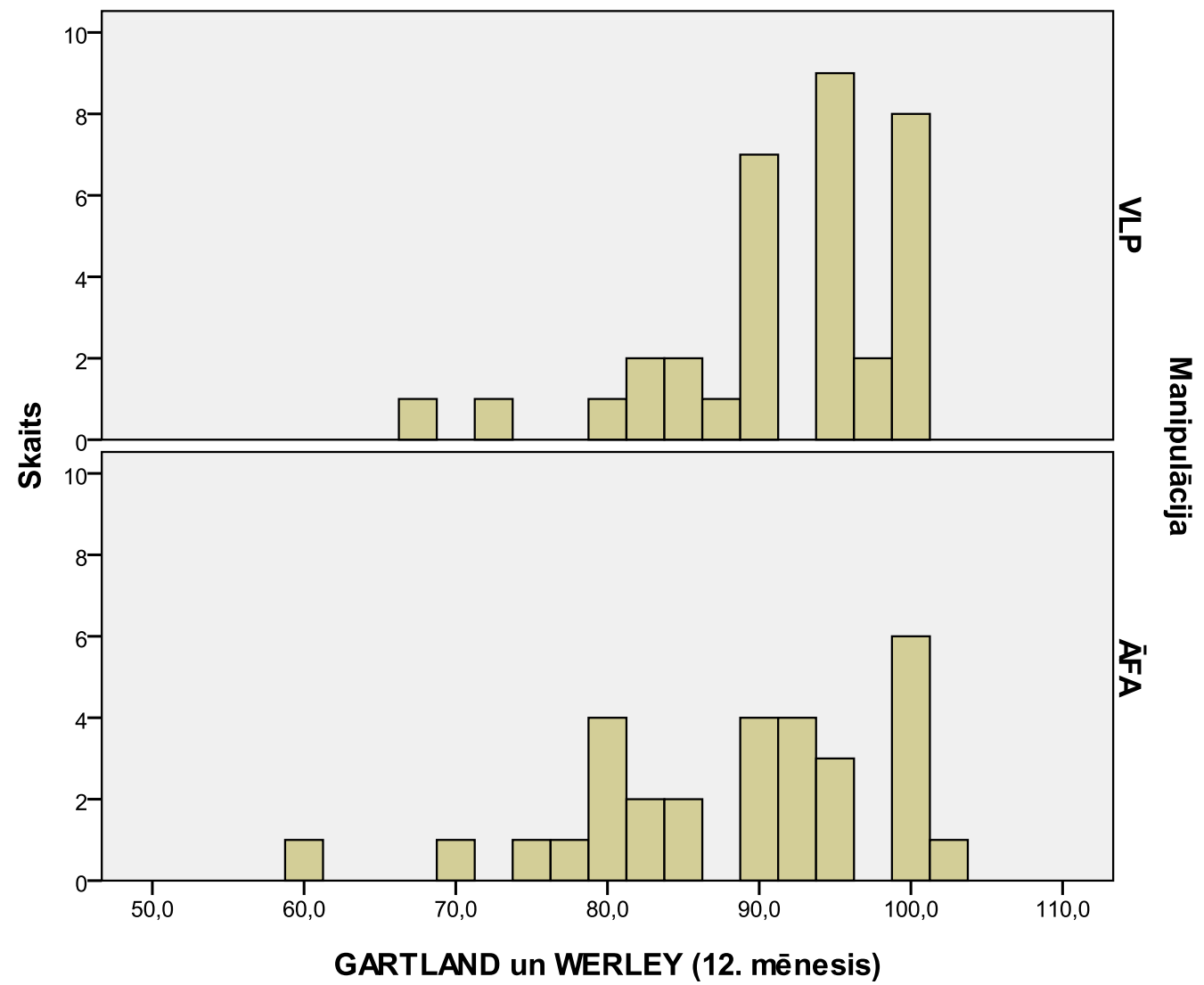

D

3.27. A, B, C, D attēls. Gartland and Werley skalas vērtējuma rezultāti dinamikā

Lai analizētu, vai Gartland and Werley skalas vērtību mērījumi statistiski būtiski atšķiras starp kontrolgrupām atkarībā no mēnešu skaita kopš operācijas, tika lietoti MannWhitney un Kolmogorova-Smirnova testi. Iegūti šādi rezultāti - statistiski būtiskas atškirīibas Gartland and Werley skalas parametra vērtībās atkarībā no manipulācijas veida sastopamas 1. un 3. mēnesī $(\mathrm{p}<0,05)$ (sk. 3.36. tabulu).

3.36. tabula

\section{Gartland and Werley skalas mērījumi, lietojot Mann-Whitney un Kolmogorova-Smirnova testus}

\begin{tabular}{|c|c|c|c|c|}
\hline & 1. mēn. & 3. mēn. & 6. mēn. & 12. mēn. \\
\hline $\begin{array}{l}\text { Ir statistiski būtiskas atšķirīibas starp } \\
\text { VLP un ĀFA grupu }\end{array}$ & jā & jā & $n \overline{\mathrm{e}}$ & nē \\
\hline p-vērtíba (Mann-Whitney tests) & $\mathbf{0 , 0 0 0}$ & $\mathbf{0 , 0 2 3}$ & 0,195 & 0,189 \\
\hline p-vērtība (Kolmogorova-Smirnova tests) & $\mathbf{0 , 0 0 0}$ & $\mathbf{0 , 0 3 5}$ & 0,425 & 0,392 \\
\hline
\end{tabular}

P-vētīibas sakrīt ar Asymp. Sig. (2-tailed) aprēḳinu materiālos. Ja kolonnā kaut viena p-vērtība mazāka vai vienāda ar 0,05 , raksta "jā̄", pretējā gadījumā "nē".

Lai noskaidrotu, vai Gartland and Werley skalas vērtību mērījumi statistiski būtiski uzlabojas (samazinās), ritot laikam pēc operācijas, tiek lietoti Wilcoxon Signed Ranks un Sign testi. Iegūti šādi rezultāti - abi testi rāda statistiski būtisku, monotonu plaukstas Gartland and Werley vērtîbas parametra uzlabojumu, ritot laikam pēc operācijas abās pētījumu grupās $(\mathrm{p}<0,01)$ (sk. 3.37. tabulu). 
Gartland and Werley skalas mērījumi, lietojot Wilcoxon Signed Ranks un Sign testus

\begin{tabular}{|c|c|c|c|}
\hline & $\begin{array}{l}\text { 3. mēn. } \\
\text { pret } 1 . \text { mēn. }\end{array}$ & $\begin{array}{l}\text { 6. mēn. } \\
\text { pret } 3 . \text { mēn. }\end{array}$ & $\begin{array}{l}\text { 12. mēn. } \\
\text { pret } 6 . \text { mēn. }\end{array}$ \\
\hline $\begin{array}{l}\text { Ir statistiski būtisks uzlabojums } \\
\text { (VLP grupa) }\end{array}$ & jā & $\mathrm{ja}$ & jā \\
\hline $\begin{array}{l}\text { Ir statistiski būtisks uzlabojums } \\
\text { (ĀFA grupa) }\end{array}$ & jā & jā & $n \bar{e}$ \\
\hline $\begin{array}{l}\text { p-vērtība (Wilcoxon Signed Ranks } \\
\text { tests) VLP grupai }\end{array}$ & $\mathbf{0 , 0 0 0}$ & $\mathbf{0 , 0 0 0}$ & $\mathbf{0 , 0 0 0}$ \\
\hline p-vērtība (Sign tests) VLP grupai & $\mathbf{0 , 0 0 0}$ & 0,000 & $\mathbf{0 , 0 0 0}$ \\
\hline $\begin{array}{l}\text { p-vērtība (Wilcoxon Signed Ranks } \\
\text { tests) ĀFA grupai }\end{array}$ & $\mathbf{0 , 0 0 0}$ & $\mathbf{0 , 0 0 0}$ & $\mathbf{0 , 0 0 1}$ \\
\hline p-vērtība (Sign tests) ĀFA grupai & $\mathbf{0 , 0 0 0}$ & $\mathbf{0 , 0 0 0}$ & 0,000 \\
\hline
\end{tabular}

P-vērtības sakrīt ar Asymp. Sig. (2-tailed) / 2 aprēḳinu materiālos. Ja kolonnā kaut viena p-vērtība mazāka vai vienāda ar 0,05, raksta “jā", pretējā gadījumā "nē".

Gartland and Werley skala sastāv no subjektīvās un objektīvās dalias. Lai noskaidrotu, vai pastāv atškirība starp pacienta subjektīvo savu spēju un sāpju vērtējumu un objektīviem, ar konkrētām vērtībām definētiem mērījumiem, tika izvērtēta korelācija starp Gartland and Werley objektīvās un subjektīvās daḷas komponentēm (sk. 3.28. A, B, C, D attēlu).

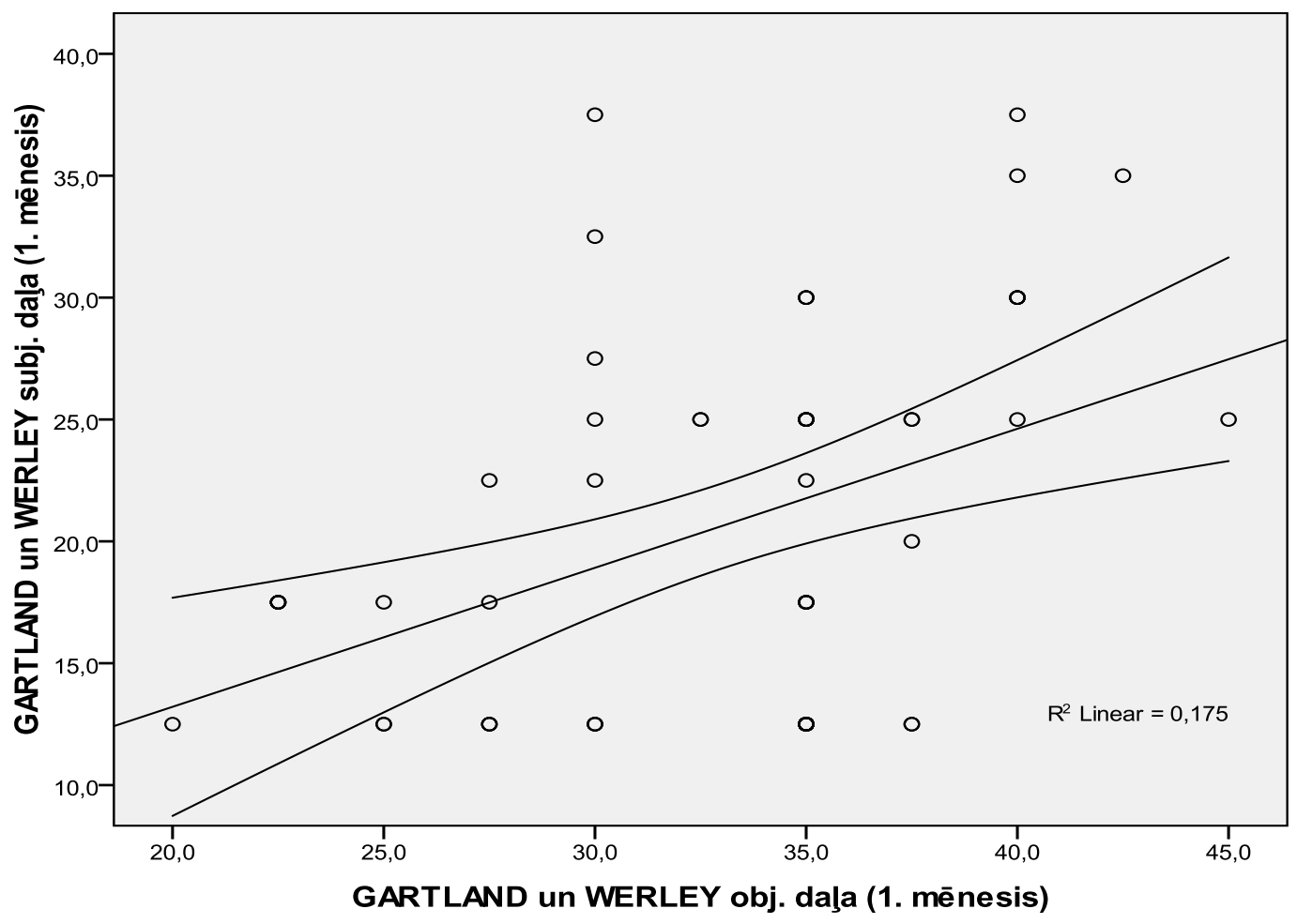

A 

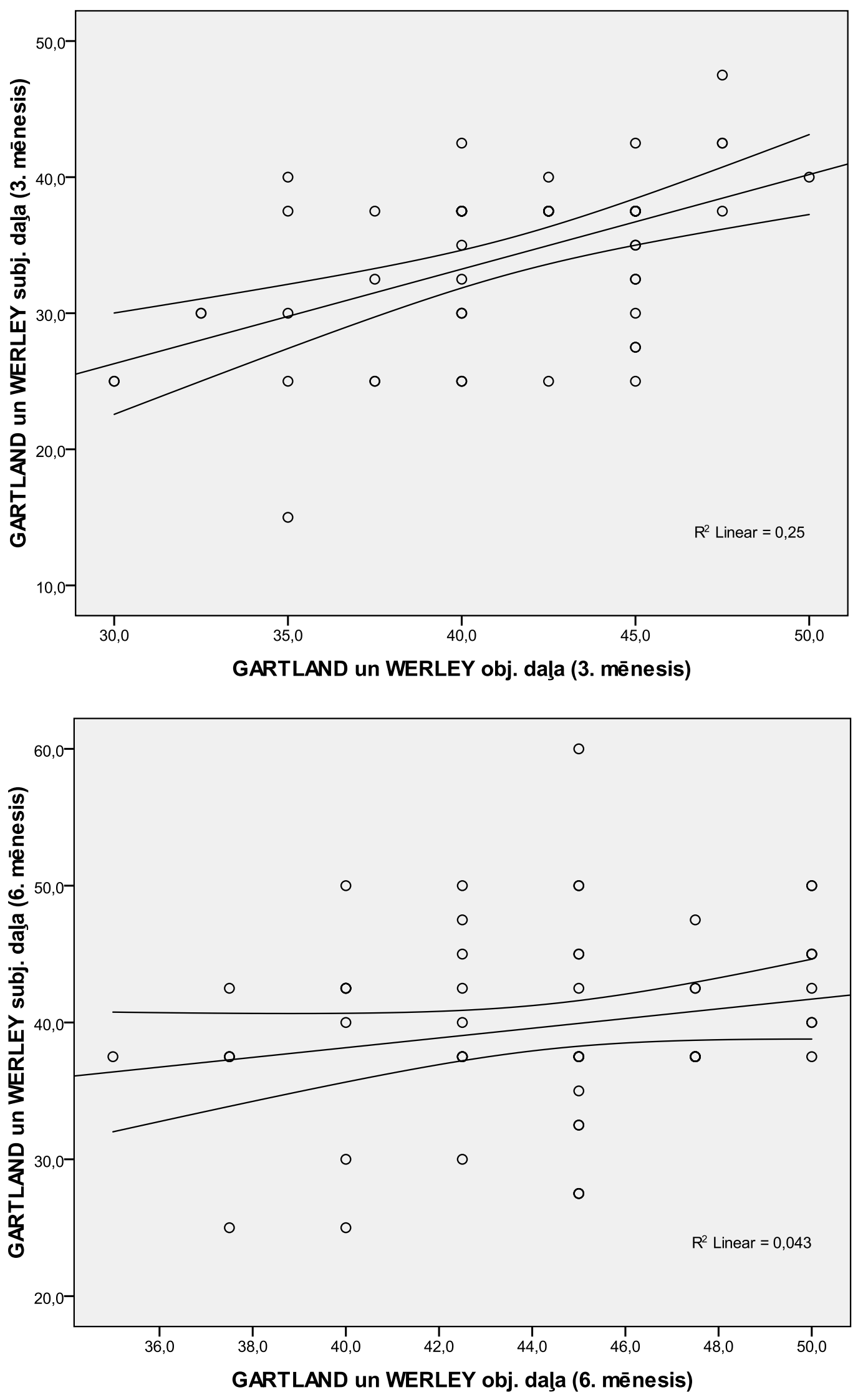


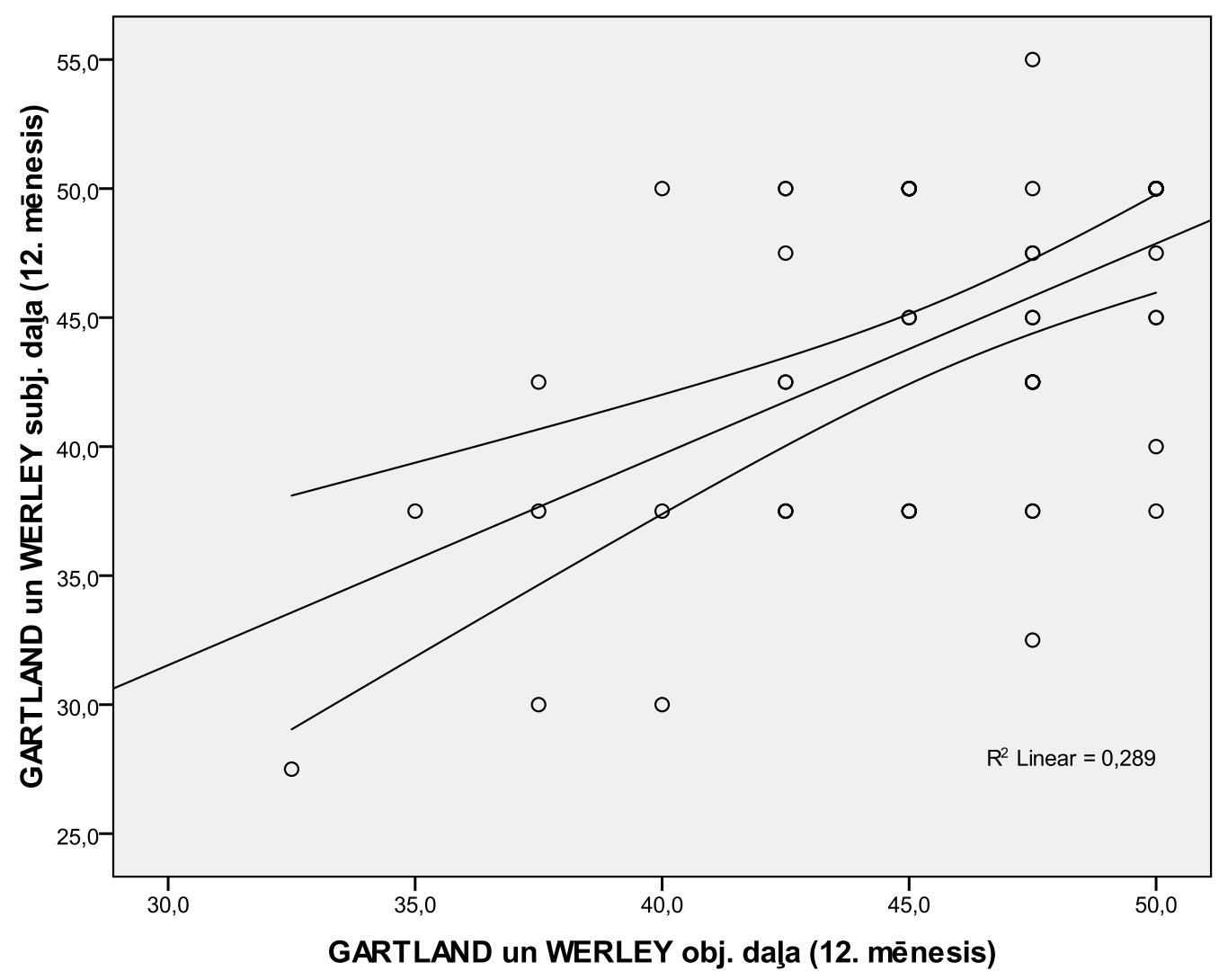

3.28. A, B, C, D attēls. Korelācija starp Gartland and Werley skalas objektīvajām un subjektīvajām komponentēm

Standarta korelācijas analīze uzrāda statistiski būtisku korelāciju starp Gartland and Werley objektīvās un subjektīvās daḷas komponentēm gan 1. mēnesī, gan 3. mēnesī, gan arī 12. mēnesī $(p<0,01)$.

Standarta korelācijas analīze neuzrāda statistiski būtisku korelāciju starp Gartland and Werley objektīvās un subjektīvās daḷas komponentēm 6. mēnesī ( $\mathrm{p}>0,05)$.

Izvērtējot Gartland and Werley skalā iegūtos datus pacientiem dažādās vecuma grupās, standarta korelācijas analīze neuzrāda statistiski būtisku Gartland and Werley vērtību atkarību no pacienta vecuma nevienā no datu reǵistrēšanas reizēm $(p>0,05)$ (sk. 3.29. attēlu). 


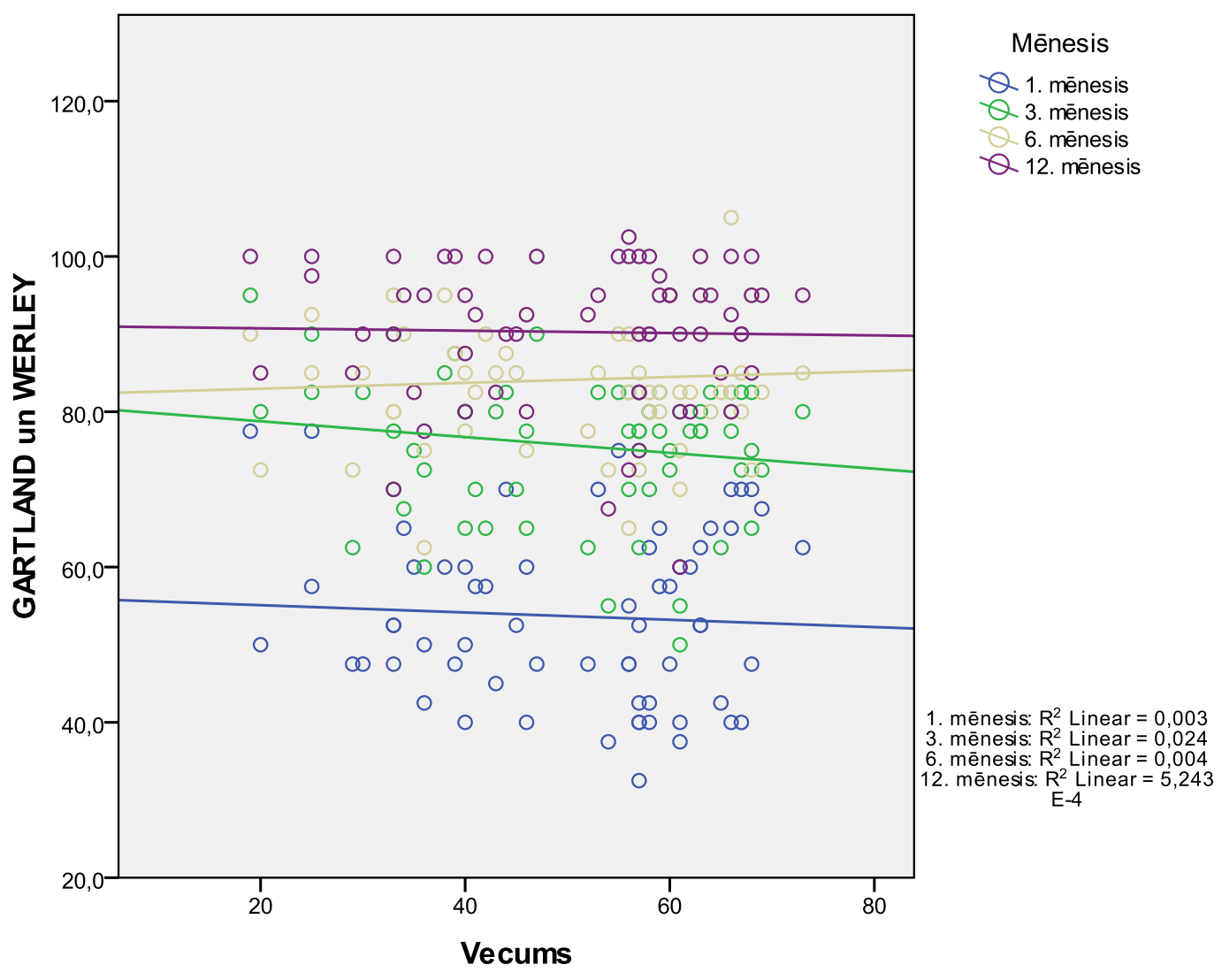

3.29. attēls. Korelācija Gartland un Werley vērtību atkarībai no pacienta vecuma

Klīniskie parametri (kustību apjoms un spēka satvērieni), kā arī subjektīvo skalu rezultāti (PRWE, MASS07, Gartland and Werley) dinamikā uzlabojās vienlīdzīgi abās grupās visu 12 mēnešu laikā pēc operācijas ar nelielu VLP grupas pārsvaru. Statistiski ticamas atšķirības starp abu grupu goniometriskiem vai dinamometriskajiem rezultātiem tika konstatētas vairākas reizes visa novērojuma laikā, taču, izṇemot pirmo pēcoperācijas mēnesi, šīs atšķirības nebija konsekventas visā pētījuma periodā. Gartland and Werley un MASS07 skalās starp grupām visa pētījuma laikā netika konstatētas statistiski ticamas atškirības ( $\mathrm{p}>0,05)$. PRWE sāpju un funkciju skalā statistiski ticamas atšķirības starp grupām tika novērotas tikai pirmajā pecoperācijas mēnesī ( $\mathrm{p}=0,001)$. MASS07 un PRWE skalās labāki rezultāti konstatēti pacientiem ar traumētu nedominanto roku, salīdzinot ar dominantās rokas traumu guvušajiem pacientiem.

\subsection{Asociētie bojājumi}

Interkarpālo saišu un TFCC bojājumu sastopamība abās grupās statistiski būtiski neatšḳīās $(\mathrm{p}=0,22)$. Sešpadsmit pacientiem tika novēroti SLIL dažādas pakāpes bojājumi (Geissler II - IV), sešiem pacientiem LTIL bojājumi (Geissler II), 11 pacientiem konstatēti dažādi TFCC bojājumi un 8 pacientiem tika atrasti gan TFCC, gan SLIL bojājumi. S-L locītavas transfiksācija ar papildu stieplēm pēc artroskopiski veiktas kaulu savstarpējas anatomiskas 
repozīcijas kopumā veikta 9 pacientiem ar Geissler IV pakāpes SLIL bojājumu. Trim pacientiem veikta TFCC refiksācija ar šuvēm pie dorsālās kapsulas, savukārt 7 pacientiem no abām grupām bija nepieciešams veikt processus styloiudeus ulnae refiksāciju ar stieplēm un savelkošo cilpu, lai likvidētu distālās radioulnārās locītavas un TFCC nestabilitāti.

Locītavas artikulāro fragmentu papildu repozīcija operācijas artroskopiskajā etapā bija nepieciešama 46 gadījumos - 20 pacientiem (59 \%) VLP grupā un 26 pacientiem (87 \%) ĀFA $\operatorname{grupā}(p=0,006)$.

\subsection{Komplikācijas}

Pētījuma laikā tika fiksētas arī atsevišķas komplikācijas (sk. 3.38. tabulu).

3.38. tabula

Komplikācijas, to biežums un sadalījums starp pētījuma grupām

\begin{tabular}{|c|c|c|c|}
\hline Komplikācija & $\begin{array}{l}\text { VLP grupa } \\
\quad(\mathrm{n}=34)\end{array}$ & $\begin{array}{l}\overline{\text { AFA grupa }} \\
(\mathbf{n}=\mathbf{3 0})\end{array}$ & $\begin{array}{c}\text { Visi pētijuma } \\
\text { pacienti }(n=64)\end{array}$ \\
\hline CRPS & $1(2,9 \%)$ & - & $1,6 \%$ \\
\hline Jatrogēns nerva bojājums & - & $2(6,6 \%)$ & $3,1 \%$ \\
\hline $\begin{array}{l}\text { Locītavas virsmas deformācija } \\
\text { pēc stiepḷu evakuācijas }\end{array}$ & - & $2(6,6 \%)$ & $3,1 \%$ \\
\hline Stieplu migrācija & $3(8,8 \%)$ & - & $4,7 \%$ \\
\hline Kopā & $4(11,8 \%)$ & $4(13,3 \%)$ & $8(12,5 \%)$ \\
\hline
\end{tabular}

CRPS - Complex Regional Pain Syndrome - kompleksais reǵionālo sāpju sindroms; VLP - volar locking plate volārā bloḳējošā plāksne; ĀFA - ārējās fiksācijas aparāts.

Visas minētās komplikācijas, izṇemot locītavu virsmas sekundāru deformāciju pēc stiepḷu evakuācijas un prognostiski iespējamu deformējošas osteoartrozes varbūtību diviem ĀFA grupas pacientiem (sk. 3.30. A un 3.30. B attēlu), vērtējamas kā nebūtiskas, jo to sekas likvidētas salīdzinoši īsā periodā pēc komplikāciju diagnostikas. Kompleksā reǵionālā sāpju sindroma pacientei sāpes, tūska un kontraktūras pirkstu locītavās tika likvidētas 6 mēnešu periodā pēc operācijas intensīvas rehabilitācijas un fizioterapijas rezultātā. Stieplu migrācijas radītie traucējumi VLP grupā izzuda tulīt pēc migrējušo stiepḷu evakuācijas. Ar stieplēm radītie radiālā digitālā nerva bojājumi likvidēti sekundāru ḳirurǵisko manipulāciju laikā - vienam pacientam bija nepieciešama neirolīzes operācija, bet pacientei tika veikta neirinomas rezekcija un bojātā nerva mikroḳirurğiska rekonstrukcija, pēc kā neirolog̣isko bojājumu simptomi pakāpeniski regresēja 6 līdz 8 mēnešu laikā. 

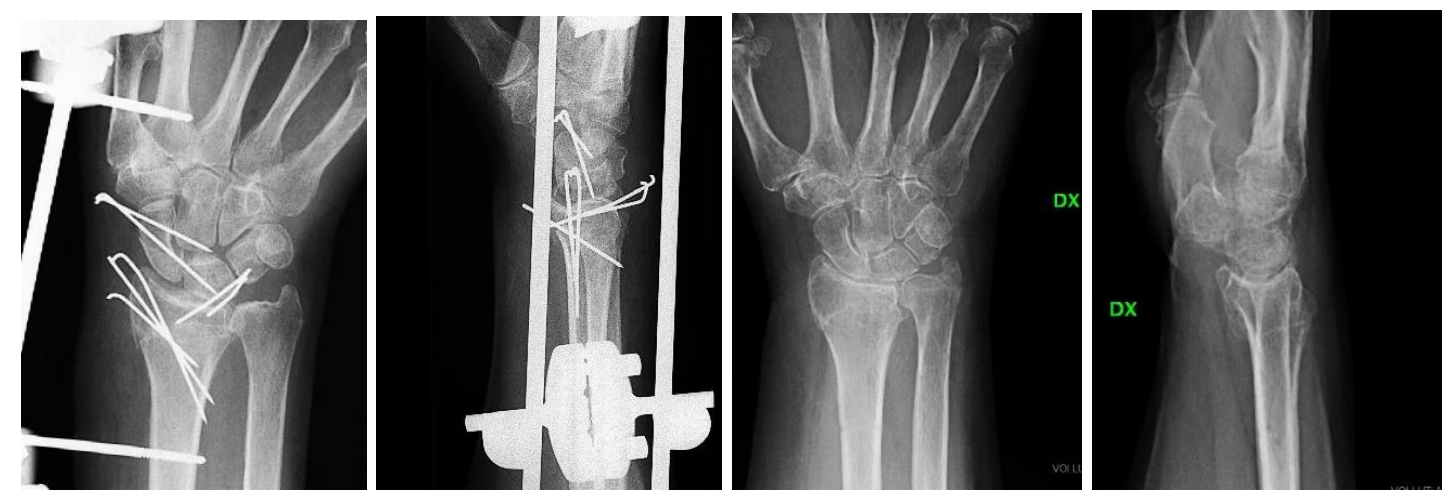

3.30. A attēls. Pacientes RTG pēc operācijas un 12 mēnešus pēc operācijas sekundāra spieḳkaula augstuma deformācija
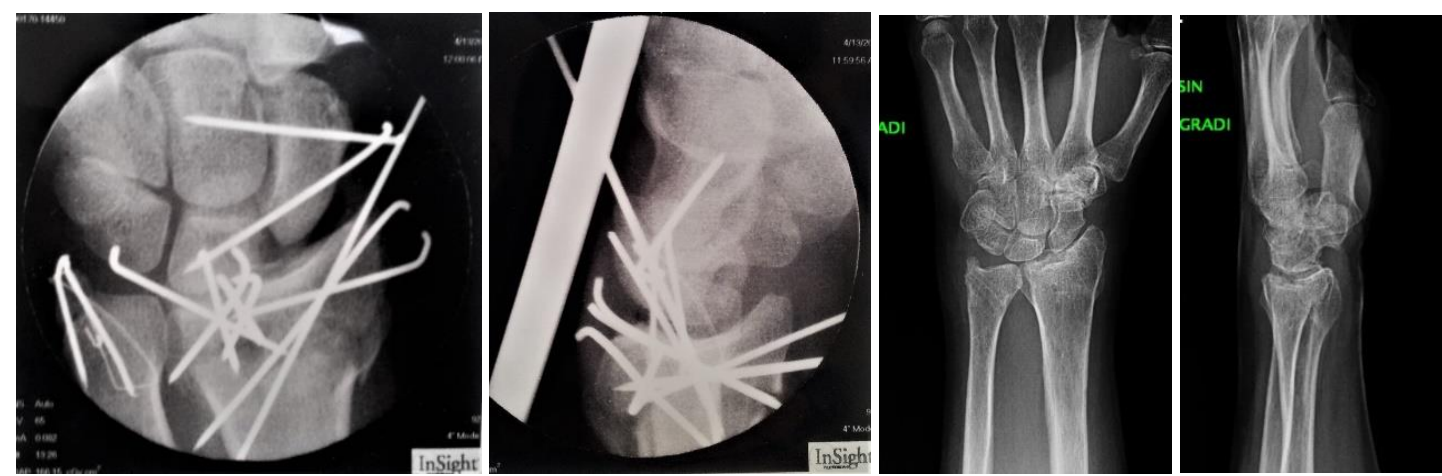

3.30. B attēls. Pacientes RTG operāciju zālē un 12 mēnešus pēc operācijas os lunatum fasetes sekundāra deformācija 


\section{Diskusija}

Pirms vairāk nekā 200 gadiem Abraham Colles (1773-1843) aprakstīja spieḳkaula "tipisko" lūzumu (Colles, 1970) un tā ārstēšanu, secinot, ka, neskatoties uz salīdzinoši vienkāršo lūzuma slēgtās repozīcijas metodi, "ekstremitātes izkropḷojums bieži vien nekavējoties atjaunojas” un, “ piel̦aujot šādas kḷūdas, pacients ir nolemts mēnešiem ilgi ciest no ievērojama ekstremitātes klibuma un nekustīguma, kuru pavada stipras sāpes, kad viṇš mēǵina kustināt plaukstu un pirkstus" (tulkojums no oriǵinālā raksta republikācijas, saglabājot autora lietoto valodas stilu, pārnesot to latviešu valodā).

Šo 200 gadu laikā diskusijas par ārstēšanas metodēm un to salīdzināšanu joprojām nav rimušas. Īpaši strauji ārstēšanas iespējas un metodes ir mainījušās kopš 1929. gada, kad Lorencs Bēlers (Lorenz Böhler) ieviesa manuālas slēgtas longitudinālas apakšdelma trakcijas un rokas kontratrakcijas aiz elkoṇa metodes konceptu. Dž. Gārtlands un Č. Verlejs (J. J. Gartland \& C. W. Werley) 1951. gadā vairākos secīgos pētījumos aprakstija, ka labus klīniskos rezultātus var sasniegt tikai gadījumos, kad ir atjaunota normālā plaukstas anatomija. Autori izgudroja subjektīvās un objektīvās funkcijas izvērtēšanas punktu skalu, kura joprojām tiek lietota arī mūsdienās. Autori arī definēja normālos anatomiskos parametrus volārai pārkarei, spieḳkaula distālā gala augstumam un locìtavas virsmas (radiālās inklinācijas) leṇkịm, pēc kuriem izvērtēt ārstēšanas procesa kvalitāti un prognozēt funkcionālo iznākumu.

Zviedrs G. Frikmans (G.Frykman) 1967. gadā 413 distālo spieḳkaulu lūzumu sērijā novēroja osteoartrītisku izmaiṇu veidošanos ne tikai radiokarpālajā locītavā, bet arī distālajā radioulnārajā locītavā (Frykman, 1967), pievēršot uzmanību, ka artikulāro lūzumu gadījumā arī DRUJ virsmas anatomiskai atjaunošanai ir būtiska nozīme vēlīno funkcionālo rezultātu sasniegšanā.

Dž. L. Knirks un Dž. B. Jupiters (J. L. Knirk and J. B. Jupiter) 1986. gadā prezentēja pētijjuma rezultātus, kur secināts, ka $91 \%$ artikulāro lūzumu, kuriem pēc repozīíjas locītavas virsmas longitudinālā nobīde saglabājas lielāka par 1 mm, un 100 \% lūzumu ar longitudinālo nobīidi virs 2 mm komplicējas ar deformējošu osteoartrozi (Knirk and Jupiter, 1986).

T. E. Trambls (T. E. Trumble) ar līdzautoriem 1994. gadā pierādīja, ka sadzijuša spieķkaula distālā gala lūzuma locìtavas virsmas nelīdzenums, pakāpiens vai plaisa, lielāka par $1 \mathrm{~mm}$, ir saistāma ar stīvumu un definējamām sāpēm (Trumble et al., 1994).

H. J. Kreders (H. J. Kreder) ar līdzautoriem 2005. gadā publicēja pêtījumu, kurā starp pārējiem rezultātiem bija veikti arī relatīvā riska lieluma aprēķini (ar konfidences intervālu 95 \%) locītavas pakāpienveida deformācijas un spraugas deformācijas gadījumos. Iegūtie rezultāti ir šādi - 2 mm un lielākas pakāpienveida deformācijas (step-off) gadījumā risks iegūt 
posttraumatisku artrozi ir 10,4 reizes lielāks (95\% CI 4,1 pret 26,6), nekā ja deformācija ir mazāka par 2 mm, savukārt spraugas deformācijas (gap) gadījumā risks iegūt posttraumatisku artrozi ir 8 reizes lielāks (95 \% CI 2,6 pret 24,7) (Kreder et al., 2005).

Pēdējo simt gadu laikā, attīstoties zināšanām un medicīniskajām tehnologijām, šo lūzumu ārstēšana no vienkāršas ieǵipsēšanas ir evolucionējusi līdz dažādu invazīvu un mazāk invazīvu metožu krustojumiem un kombinācijām. Plaukstas lūzumu ārstēšanā uzkrātie zinātniskie pierādījumi (evidence) un ar̄̄ vispārēja log̣ika liecina, ka spieķkaula anatomijas atjaunošana ir tieši saistìta ar iespējām atgūt plaukstas locītavas funkcijas. Tātad musdien̄̄gai slēgtai vai ķirurǵiskai ārstēšanai ir jācenšas atjaunot:

1. Locītavas viendabīgumu (mazinot locītavas skrimšla nodiluma un deǵeneratīvo izmaiņu iespējas).

2. Spieķkaula garumu un radiālo līmenisko projekciju (atjaunojot karpālo un radioulnāro kinemātiku).

3. Kustības (pirkstu, plaukstas un apakšdelma normālu funkcionālo aktivitāšu saglabāšanai).

4. Stabilitāti (lai saglabātu kaula garumu un projekcijas nemainīgumu lūzuma dzī̌šanas laikā).

Ķirurǵiskās ārstēšanas metodes iedala no mazinvazīvām, kāa, piemēram, slēgta repozīcija fluoroskopijas kontrolē ar transkutānu stiepḷ fiksāciju ar vai bez ĀFA aplikācijas, līdz visu 3 kolonnu plākšņu fiksācijām, kā arī abpusējām vaļējām osteosintēzēm ar fragmentu specifiskām anatomiskajām plāksnēm.

Ṇemot vērā, ka manā darbā ir izmantotas tikai divas no visām iespējamām spieḳkaula distālā gala lūzumu ārstēšanas metodēm - fiksācija ar stieplēm un ĀFA, kā arī osteosintēze ar VLP -, tad par pārējām izvērsta diskusija netiks veidota.

\subsection{Par $\bar{A} \mathbf{F A}$}

Ārējās fiksācijas ierīces sāka izmantot kopš 20. gadsimta 40. gadiem, tomēr plašu popularitāti tās ieguva 1979. gadā, kad Ž. Vidals (Jacques Vidal) prezentēja ligamentotakses konceptu, piedāvājot to lietot artikulāro lūzumu ārstēšanā gūžas, ceḷa, pēdas, plaukstas locītavās, kā arī mugurkaula traumas gadījumos. Ligamentotakses princips ietver iestiepuma veidošanu caur kapsulas un saišu struktūrām, kura rezultātā tiek panākta kaula fragmentu repozīcija (Vidal J, 1979). Autors arī aprakstīja šī principa sekmīgu lietošanu multiplu šķembainu lūzumu ārstēšanā, kuru gadījumos iekšējās fiksācijas metodes tehniski nebija lietojamas. Pagājušā gadsimta 80. un 90. gados tika radītas daudzas dažādas ĀFA modifikācijas un šì metode tika plaši lietota tieši šķembainu un artikulāru spieḳkaula distālā gala lūzumu 
ārstēšanā. Apmēram 10 gadu laikā pēc $J$. Vidal publikācijas parādījās pētījumi, kuros konstatēja ar šo metodi saistītās komplikācijas. Visbiežākās mīksto audu pārstiepšanas radītās problēmas bija pirkstu kontraktūras, reflekss simpātiskā distrofija jeb, kā mūsdienās to dēvē, kompleksais reǵionālā sāpju sindroms (CRPS - angl.), nervu disfunkcija, kā arī tehniskas grūtības panākt fragmentu anatomisku repozīciju un atjaunot spieķkaula distālā gala augstumu, izmantojot tikai iestiepumu (Kaempffe et al., 1993; McQueen et al., 1992; Weber and Szabo, 1986). Mūsdienu tehnologijas, kā arī iegūtās zināšanas un izpratne par ārējās fiksācijas metodes lietošanu ḷauj izmantot šo ārstēšanas principu jaunā gaisotnē. Šobrīd ārējās fiksācijas metode tiek lietota kopā ar lūzuma fragmentus atbalstošām stieplēm, l,aujot mīkstos audus fiksēt neitrālā iestiepumā, lietojot limitētas val̦ējas repozīcijas metodes, kā arī veicot kaula defektu aizpildīšanu ar kaula transplantātiem vai kaula aizvietotājiem. Iestiepums neitrālā pozīcijā pieḷauj uzsākt tūlītēju pirkstu kustināšanu, savukārt, izmantojot papildu stabilizējošās stieples, ĀFA noṇemšanu var veikt 4 līdz 6 nedēḷas pēc operācijas, atstājot stieples kaulā un ḷaujot uzsākt kontrolētu kustību iestrādi (Wolfe, 2017).

Daḷa autoru, kuri veikuši pētījumus par spieḳkaula distālā gala lūzumu ārstēšanu ar kombinētām ārējās fiksācijas metodēm, norāda 59-93\% labus un teicamus rezultātus, vienlaikus atzīstot, ka pastāv statistiski būtiska korelācija starp lūzuma sarežǵìtības pakāpi un gala iznākumu (Arora and Malik, 2005; Jakim et al., 1991; Kuner et al., 2002; Rikli et al., 1998; Siripakarn et al., 2013). Kombinējot nosacīti īslaicīgu statisko ārējo fiksāciju (līdz četrām nedēḷām) ar papildu fiksējošām stieplēm, rezultātā var sasniegt līdz $110^{\circ}-120^{\circ}$ kopējās fleksijas / ekstensijas un $120^{\circ}-150^{\circ}$ pronācijas / supinācijas apjoma (Duramaz et al., 2018; Wright et al., 2005).

\subsection{Par VLP}

Artikulāro lūzumu vaḷēja repozīcija un iekšèjā fiksācija ar plāksnēm vēsturiski ir bijusi indicēta gados jauniem, aktīviem pacientiem, kuriem ir laba kaulu struktūra. Ar šo metodi var sasniegt labāku kaula fragmentu fiksāciju un locītavas virsmu veidojošo fragmentu fiksāciju, ko nav iespējams panākt ar slēgtām manipulācijām, ligamentotaksi vai perkutānām repozīcijas metodēm. Šì metode var tikt izmantota arī kā alternatīva citām metodēm, ņemot vērā pacienta vēlmes vai arī ķirurga izvēli. Volārās atbalsta plāksnes lietošanas rezultāti 29 pacientiem un 31 lūzumam pirmo reizi tika prezentēti 2002. gadā (Orbay and Fernandez, 2002). Ziņojumā akcentēta plāksnes pozicionēšana starp kaulu un $m$. pronator quadratus, kas ievērojami samazina saliecējcīpslu kairinājuma risku. Tika secināts, ka stabila volārā iekšējā fiksācija kombinācijā ar distālo mīksto audu struktūru pasargāšanu no mehāniskiem bojājumiem samazina kaula transplantātu lietošanas nepieciešamību, kā arī atliecējcīpslu bojājuma risku, 
kas bieži tika novērots dorsālo plākšṇu lietošanas gadījumos. Volārās bloḳētās plāksnes lielākās priekšrocības ir tās rigidā fiksācija pat visnestabilāko un škembaināko lūzumu gadījumos, kas dod iespēju uzsākt agrīnu kustību iestrādi, minimāli lietojot ārējos fiksatorus (noṇemamas plaukstas locītavas ortozes vai longetes) (Wright et al., 2005). Osada ar līdzautoriem biomehāniskajā modelī izvērtēja un pierādīja, ka tikai volārā bloḳējošā plāksne atškirībā no 6 citiem fiksācijas veidiem spēj izturēt $250 \mathrm{~N}$ lielu pretestību, kas ir fiziologiskais ar plaukstas un pirkstu kustībām asociējamais sagaidāmais spēks plaukstas locītavas līmenī (Osada et al., 2003).

Gados vecākiem, mazāk aktīviem pacientiem, kā arī pacientiem ar izteiktu osteoporozi vaḷējās osteosintēzes metodes tradicionāli tika uzskatītas par kontrindicētām. Šiem pacientiem parasti tika konstatēts lielāks komplikāciju risks, ieskaitot fiksācijas stabilitātes zaudējumu, nesaaugšanu vai nepareizu saaugšanu, kā arī reflekss simpātiskās distrofijas veidošanās risku. Ieviešot volārās bloḳējošās plāksnes, vecāka gadagājuma un osteoporozes skartu pacientu spieḳkaula distālo galu lūzumu vaḷējas repozīcijas un iekšējās fiksācijas apmierinošo un labo rezultātu īpatsvars strauji pieauga. Subhondrālās zonas atbalstišana ar plāksnē bloḳētajām skrūvēm ievērojami samazināja lūzuma sekundāras dislokācijas vai atsevišḳu artikulāro fragmentu noslīdējuma risku (Orbay and Fernandez, 2004).

Izvērtējot iepriekš sniegto informāciju, logiisks ir spriedums, ka vienmēr ir bijusi aktuāla vēlēšanās salīdzināt šīs divas atšķirīgās ārstēšanas metodes, to priekšrocības, iespējamos trūkumus un - galvenais - iespējamos ārstēšanas rezultātus.

\subsection{Abu metožu salīdzinājums}

Diskusijas tālākajā sadaḷā demonstrēšu dažus piemērus, kuros ir norādes uz ĀFA lietošanas vai plākšṇu fiksācijas priekšrocībām, salīdzinot ar otru ārstēšanas metodi. Piemēriem izvēlējos tikai prospektīvu randomizētu pētījumu rezultātus, jo retrospektīvajos pētījumos šis būtiskais kvalitātes rādītājs nav ievērots. Visos pētījumos ir ārstēti un novēroti pacienti tikai ar dislocētiem, artikulāriem spieķkaula distālā gala lūzumiem.

H. Kapūra (H. Kapoor) un līdzautoru 2000. gadā publicētajā rakstā tiek ziṇots par pētījumu, kurā iekḷauti 90 pacienti ar vidējo vecumu 39 gadi. Pacienti randomizēti trijās grupās - pa 30 katrā. Pirmās grupas pacienti ārstēti ar slēgtu repozīciju un imobilizāciju ğipša longetē. Šīs grupas ārstēšanas rezultāti ir vissliktākie un tālākai datu analīzei netiks prezentēti. Pacientu novērošanas laiks - 1 gads. Vēlīno rezultātu izvērtēšanai tika lietota Sarmiento skala (Sarmiento assessment score), jo, kā norāda paši autori, DASH skala raksta tapšanas brīdī vēl nebija ieviesta. Iegūtie rezultāti ĀFA grupā - $80 \%$ labu un teicamu rezultātu, $20 \%$ vidēju 
rezultātu, savukārt plākšṇu grupā $63 \%$ labu un izcilu rezultātu, 26 \% vidēju rezultātu un $11 \%$ sliktu rezultātu (Kapoor et al., 2000).

H. Dž. Kreders (H. J. Kreder) ar līdzautoriem 2005. gadā publicēja prospektīva randomizēta pētījuma rezultātus, kurā tika iekḷauti 179 pacienti vecumā no 16 līdz 75 gadiem. Novērojuma laiks bija divi gadi pēc operācijas. ĀFA grupā tika novēroti 88 pacienti, savukārt plākšņu grupā 91 pacients. Jāpiebilst, ka plākšṇu grupā tika izmantotas arī dorsālās vai radiālās kolonnas plāksnes, padarot šo grupu neviendabīgu. Autoru izdarītie secinājumi ir šādi - Grip un Pinch rādītāji pirmajos sešos mēnešos bija labāki ĀFA grupai. Divu gadu novērojuma laikā ĀFA grupas pacienti plaukstas funkcijas atguva ātrāk un kopsummā sasniedza labākus funkcionālos rezultātus, nekā plākšņu grupas pacienti (Kreder et al., 2005).

R. Šukla (R. Shukla) un līdzautori 2014. gadā publicēja prospektīva randomizēta pētījuma rezultātus, kurā tika novēoti 110 pacienti ar vidējo vecumu $39 \pm 13$ gadi. ĀFA grupā tika ārstēti 68 pacienti, savukārt VLP grupā 42 pacienti. Rezultātu apkopošanai tika izmantota Grīna un O’Braiena skala (Green \& O`Brien score). Gadu pēc operācijas ĀFA grupā 85,5\% bija labi un teicami rezultāti, savukārt VLP grupā tikai 73,3 \% gadījumu novēroja labus un teicamus rezultātus. Kā papildu secinājums par ĀFA lietošanu artikulāro spieķkaula distālo galu lūzumu ārstēšanā tika minēts, ka ĀFA grupā visiem pacientiem, kuri bija jaunāki par 50 gadiem, rezultāti bija labāki nekā vecākiem par 50 gadiem (Shukla et al., 2014).

Šis secinājums sasaucas arī ar mana promocijas darba hipotēzes daḷu, proti, ĀFA aplikāciju var sekmīgi lietot arī gados jauniem pacientiem, ne tikai veciem cilvēkiem ar osteoporotiskām izmain̄ām kaulos.

Č. Ma (Chuang Ma) un līdzautori 2016. gadā prezentēja pētījumu ar 123 pacientiem, kuri visi bija vecāki par 65 gadiem. ĀFA grupā tika iekḷauti 58 pacienti, savukārt VLP grupā 65 pacienti. Klīniskie rezultāti - kustību apjoms, spēks abām grupām attīstījās samērā vienādi visa pētījuma gaitā, ar nelielu pārsvaru par labu ĀFA grupai, taču bez statistiski ticamām atšķirībām. Abas grupas būtiski atšḳ̄īās komplikāciju skaita ziṇā: ĀFA grupā novēroja 14 dažādas komplikācijas ar vienu gadījumu, kam bija nepieciešama atkārtota ķirurgiska ārstēšana, savukārt VLP grupā - 31 komplikāciju, no kurām sešos gadījumos bija nepieciešama reoperācija (Ma et al., 2016).

M. K. T. Vilke (M. K. T. Wilcke) ar līdzautoriem 2011. gadā prezentēja prospektīva randomizēta pētījuma rezultātus, kurā piedalījās 63 pacienti līdz 70 gadiem. VLP grupu veidoja 33 pacienti, savukārt 30 pacientiem tika veiktas ĀFA un stiepḷu osteosintēzes. Rezultātu apkopojumā konstatēts, ka VLP grupai pirmajos sešos mēnešos bija labāki kustību apjoma un satvēriena spēka mērījumu rezultāti, kā arī DASH un PRWE skalu rezultāti. Gadu pēc operācijas š̄̄s statistiski ticamās un būtiskās atšķirības bija kḷuvušas pavisam nelielas vai pilnībā 
izzudušas. Autoru secinājums - VLP lietošana dod iespēju ātrāk sasniegt labus un teicamus rehabilitācijas rezultātus (Wilcke et al., 2011).

Dž. H. Viliksens (J. H. Williksen) ar līdzautoriem 2013. gadā publicēja 111 pacientu prospektīva randomizēta pētījuma rezultātus. Tajā tika iekḷauti pacienti vecumā no 20 līdz 84 gadiem. ĀFA grupā pēc randomizācijas tika iekḷauti 59 pacienti, savukārt VLP grupā 52 pacienti. Pacientu novērošanas periods pēc operācijas bija pieci gadi. Autoru publicētajos rezultātos secināts, ka VLP grupā ilgtermiṇā novērojama labāka apakšdelma supinācija / pronācija, spieḳkaula augstuma, kā arī elkoṇkaula galviņas augstuma attiecība un plaukstas satvēriena spēks. Komplikāciju ziṇā ĀFA grupā konstatētas 18 komplikācijas (30 \%), savukārt VLP grupā konstatētas pavisam 15 komplikācijas (29\%). Astoṇos gadījumos (15\%) viena gada laikā pēc pirmās operācijas bija nepieciešama plāksnes evakuācija. Seši no visiem gadījumiem klasificēti kā ķirurğiskās kḷūdas. Raksta autori ir pieminējuši, bet nav uzsvēruši un izvērtējuši faktu, ka operācijas veikuši 11 dažādi ķirurgi, likumsakarīgi - pieredze, operācijas tehnika un implanta novietošanas precizitāte noteikti nav bijusi identiska visos gadījumos (Williksen et al., 2013).

Spieķkaula distālā gala artikulāro lūzumu ārstēšanas rezultātu apzināšana pēdējo divu dekāžu laikā ir kḷuvusi par vairāku sistematizētu metaanalīžu objektu. Gandrīz visi autoru kolektīvi ir secinājuši, ka lūzumu heterogenitāte, iznākumu fiksēšanas metožu dažādība, atšķirības ķirurğiskajā tehnikā un pacientu populācijās ir radījušas milzīgas grūtības precīzu, visiem akceptējamu secinājumu pieņemšanā.

M. M. Dž. Valenkampa (M. M. J. Wallenkamp) ar līdzautoriem šādā metaanalīzes pētījumā konstatēja, ka pacientiem, kuri ārstēti ar VLP, visos pētījumos ir bijuši būtiski labāki DASH rezultāti, taču klīniski tie atšḳīrušies tikai pirmajos trijos mēnešos pēc operācijas (Walenkamp et al., 2013).

Ķīnas autoru kolektīvs Xuetao Xie vadībā 2013. gadā publicēja metaanalīzes pētījumu, kurā secināts, ka VLP grupā ir konstatējami labāki apakšdelma pronācijas apjomi, precīzāk iespējams atjaunot spieķkaula distālā gala anatomiju - volāro pārkares leṇķi un spieḳkaula augstumu, kā arī retāk sastopamas komplikācijas. Pacienti, kuriem tika veiktas operācijas ar plāksnēm, ātrāk sasniedza labus un apmierinošus rezultātus, kā arī ātrāk atgriezās darbā (Xie et al., 2013).

Metaanalīzes pētījumā, kurš tika publicēts 2018. gadā C. Dž. C. Guka (C. J. C. Gouk) vadībā, secināts, ka lielākā daḷa objektīvo un subjektīvo parametru 12 mēnešu laikā pēc spieķkaula distālo artikulāro lūzumu ārstēšanas ar VLP vai ĀFA klīniski un statistiski būtiski neatšķiras. Atšķirības tika konstatētas tikai elkoņkaula galviņas augstuma parametros anatomiski pareizāk tas tika atjaunots VLP grupā. VLP grupā novērotas biežākas reoperācijas, 
savukārt ĀFA grupā vairāk infekcijas gadījumu. Autoru secinājums ir, ka šobrīdējās literatūras dati liecina par VLP spēju labāk atjaunot anatomiskos locītavas parametrus un radīt labākus subjektīvos rādītājus pirmo trīs pēcoperācijas mēnešu laikā, piebilstot, ka šai grupai tomēr ir lielāks reoperācijas nepieciešamības risks (Gouk et al., 2018).

Biežākie secinājumi ir šādi - neņemot vērā daudzās priekšrocības, kā, piemēram, stabila fragmentu fiksācija, iespēja ātrāk uzsākt aktīvo kustību iestrādi un plaukstas locītavas slogošanu ilgtermiņā VLP lietošanai nav būtisku, statistiski ticamu priekšrocību, salīdzinot ar ĀFA lietošanu artikulāro spiek̦kaula distālo lūzumu ārstēšanā (Costa et al., 2014; Roh et al., 2015).

Ir pierādīts, ka VLP metode ḷauj rigidi fiksēt fragmentus, bet iepriekšējos pētījumos nav bijis iespējams precīzi verificēt, vai ar fiksēto plāksni visi fragmenti atrodas anatomiskā pozīcijā. Lielākajā daḷā rakstu tiek pieminētas dažāda lieluma pakāpienveida (step-off) un plaisveida ( $\mathrm{gap}$ ) locītavas virsmu deformācijas, kuras palikušas nenovērstas, izmantojot tikai fluoroskopijas kontroli operācijas laikā. Fiksējot ar ĀFA un stieplēm, fragmentu anatomiska repozīcija ir vēl grūtāka un stabilitāte mazāka, biežāk iespējamas sekundāras dislokācijas. Abos gadījumos, ja vien netiek veikta locītavas artrotomija artikulāro fragmentu repozīcijai, kas rada papildu traumas mīkstajos audos un potenciāli palielina kontraktūras veidošanās risku, precīzas repozīcijas iespējas AO C2 un C3 lūzumiem ne vienmēr ir tehniski iespējamas.

\subsection{Artroskopija un distāli, artikulāri spieḳkaula lūzumi}

Lai mazinātu neprecīzas repozīcijas risku un vizualizētu lūzuma vietu, tiek piedāvāta artroskopiski asistēta lūzumu ārstēšanas metode.

Artroskopijas lomai šajā pētījumā ir nepieciešams pievērst īpašu uzmanību. Pêtījuma rezultāti, lietojot plaukstas artroskopiju kaula fragmentu pozīcijas noteikšanā un vizuāli kontrolētajā repozīcijā, apstiprina konkrētās metodes nepieciešamību šo lūzumu ārstēšanā. Pēdējo divu dekāžu laikā rokas ķirurgi aizvien biežāk izmanto gan diagnostiskas, gan terapeitiskas plaukstas artroskopijas. Arī spieķkaula distālā gala artikulāro lūzumu ārstēšanā artroskopiski asistētā ķirurğija kḷūst aizvien populārāka. Vienu no pirmajiem rakstiem par spieķkaula distālo artikulāro lūzumu ārstēšanu ar artroskopiski asistētu metodi 1993. gadā publicēja H. Dž. Levi (H .J. Levy). Viņš, veicot vaḷēju volāru repozīciju un osteosintēzi, artroskopu ievietoja locītavā, izmantojot jau izveidoto ķirurǵisko pieeju. Šādā veidā tika saudzēta volārā kapsula un locītavu stabilizējošās saites, kuras tiktu pārgrieztas locìtavas vaḷējās vizualizācijas gadījumā (Levy and Glickel, 1993). 
T. L. Vaipls (T. L. Whipple) 1995. gadā uzsvēra, ka lūzuma virsmas un konfigurācijas vizualizācija, plaukstas locītavas lavāžas iespēja, kā arī stiepḷu ievadīšana vizuālā kontrolē ḷauj veikt precīzāku fragmentu repozīciju, kas noteikti nav iespējama, lietojot tradicionālo fiksāciju ar stieplēm un ĀFA (Whipple, 1995).

V. B. Geislers (W. B. Geissler) 1995. un 1999. gadā publicēja artroskopiski asistēto perkutānu vai limitētu vaḷēju osteosintēžu metožu aprakstus, kā arī norādīja uz iespējamo papildu bojājumu atrašanas varbūtību un to novēršanas nepieciešamību (Geissler, 1995; Geissler and Freeland, 1999; Geissler et al., 1996).

Japāṇu plaukstas ķirurgu grupa, kuru vadīja Kazuteru Doi, 1999. gadā publicēja prospektīva randomizēta pētîjuma rezultātus, kurā 34 pacienti tika ārstēti, lietojot fiksāciju ar stieplēm un ĀFA plaukstas artroskopijas kontrolē, savukārt kontroles grupā tika iekḷauti 48 pacienti, kuriem veiktas gan fiksācijas ar stieplēm un ĀFA, gan vaḷējas repozīcijas un fiksācijas ar plāksnēm. Vidējais pacientu novērošanas laiks bija 31 mēnesis. Rezultātā, izvērtējot pacientu ārstēšanas iznākumus, tika konstatēts, ka artroskopiski asistēto operāciju pacientu grupā fiksēti labāki rezultāti gan pēc Gartland \& Werley, gan Green \&O`Brien skalas. Artroskopiski asistētajā grupā novēroti arī labāki plaukstas fleksijas-ekstensijas, radiālāsulnārās deviācijas, kā arī plaukstas satvēriena (Grip) rādītāji. Radioloǵisko izmeklējumu rezultāti liecināja, ka artroskopiski asistētajā grupā tika sasniegta labāka volārās pārkares un spieḳkaula / elkoṇkaula distālā savstarpēja novietojuma (ulnar variance) atjaunošana, kā arī artikulāro pakāpienu un plaisu novēršana bija sekmīgāka nekā konvencionāli ārstēto pacientu grupā. Visiem minētajiem parametriem atšķirības bija statistiski ticamas $(p<0,05)$. Autoru kolektīvs secināja, ka artroskopiskās metodes lietošana šo lūzumu ārstēšanā samazina pēcoperācijas kontraktūru veidošanās risku, kā arī potenciālu posttraumatiskās artrozes rašanās risku. Autori rekomendēja artroskopiski asistētu spieķkaula distālā gala artikulāro lūzumu ārstēšanu pacientiem jebkurā vecumā, kuri ir jaunāki par 70 gadiem (Doi et al., 1999).

Būtiskākā artroskopijas priekšrocība ir iespēja locītavu vizualizēt uz ekrāna reālā laikā, ievērojamā palielinājumā un dabiskās krāsās, ko nespēj nodrošināt neviena cita palīgdiagnostikas metode. Fluoroskopiskais kaula attēls, kuru var iegūt operācijas zālē, ir ar daudz mazāku izšķirtspēju nekā ar videokameru iegūstamais attēls artroskopijas laikā, tāpēc pat visniecīgākās fragmentu neatbilstības ir vizualizējamas (Lutsky et al., 2008).

C. C. Edvards (C. C. Edwards) 2001. gadā publicēja pētījumu, kurā pēc spieḳkaula distālā artikulārā lūzuma it kā apmierinošas, slēgtas repozīijas un fiksācijas ar stieplēm tika veikta plaukstas locītavas artroskopija. Tika konstatēts, ka artikulāro fragmentu neatbilstība vai nobīde, lielāka par 1 mm, ir 33 \% pacientu (Edwards et al., 2001), savukārt K. Latski (K. Lutsky) 
2008. gadā līdzīgā pētījumā konstatēja $36 \%$ nepieciešamību veikt papildu repozīciju lūzuma fragmentiem.

Jo augstāka ir traumas enerǵija, jo vairāk artikulāro fragmentu, jo lielāka ir papildu manipulāciju iespējamība artroskopijas laikā. AO-C3 lūzumu pacientiem papildu manipulācijas artroskopijas kontrolē var būt nepieciešamas līdz 71 \% gadījumu (Auge and Velazquez, 2000). Nepieciešamība veikt papildu manipulācijas ar fragmentiem artroskopijas laikā manā pētījumā bija biežāka nekā iepriekš sastopamajos pētījumos. Neraugoties uz lielo papildu manipulāciju skaitu ĀFA grupā, arī VLP grupas pacientiem šo manipulāciju bija nepieciešams veikt biežāk, nekā aprakstīts literatūrā (Abe and Fujii, 2017; Burnier et al., 2018; Khanchandani and Badia, 2013; Ono et al., 2010; Ono et al., 2012).

Tālākajā diskusijas dạ̣ā pievērsǐšos artroskopiski konstatējamiem mīksto audu bojājumiem, to sastopamības biežumam, kā arī rekomendētajām ārstēšanas metodēm. Iespējams, ka iepriekšējos salīdzinošajos pētījumos plākšṇu grupām, kurām uzsāka agrīnu kustību iestrādi, un ĀFA grupām, kurām imobilizācija bija ilgāka, tieši nediagnosticētie asociētie mīksto audu bojājumi neḷāva sasniegt labākus gala rezultātus. Asociētie mīksto audu bojājumi ilgtermiṇā ietekmē klīniskos un funkcionālos rezultātus, tāpēc artroskopiskā locītavas izvērtēšana ir svarīgākais posms precīzas un piln̄̄gas diagnostikas sasniegšanā, kā arī tā var sekmēt ātrāku pacienta izveseḷošanos (Lindau, 2017).

No visiem iespējamiem asociētajiem mīksto audu bojājumiem ir jāizceḷ trīs galvenie: triangulārā fibroskrimšla kompleksa (TFCC), skafolunātās interosālās saites (SLIL) un lunotrikvetrālās interosālās saites (LTIL) bojājumi. Šīs struktūras parastajās rentgenogrammās un intraoperatīvās fluoroskopijas attēlos nav vizualizējamas, taču artikulāro spieḳkaula distālo galu lūzumu gadījumos mūsdienās, ja to pieḷauj tehniskais nodrošinājums un personāla pieredze, būtu vēlama šo struktūru vizualizācija un bojājumu gadījumos arī fiksācija. SLIL un LTIL bojājumu gadījumos visbiežāk izmanto Geissler klasifikāciju, savukārt TFCC bojājuma gadījumos - Palmer klasifikāciju.

T. Ogava (T. Ogawa) ar līdzautoriem 2013. gadā aprakstīja 89 pacientu grupu, kam tika veiktas artroskopiski asistētas spieḳkaula distālā gala artikulāro lūzumu osteosintēzes. Pacientu vidējais vecums bija 62,2 gadi (17-92 g. v.). Rezultātā 59\% gadījumu tika konstatēti TFCC bojājumi, 54,5 \% gadījumu - SLIL bojājumi un 34,5 \% gadījumu - LTIL bojājumi. Tikai 17,1 \% gadījumu netika konstatēts neviens no minētajiem bojājumiem (Ogawa et al., 2013).

S. Rulē (S. Roulet) ar līdzautoriem 2019. gadā publicēja rakstu, kurā ir izvērtēti artroskopiski atrasto asociēto bojājumu gadījumi 57 pacientu grupai ar vidējo vecumu 43 gadi (18-64 g. v.). Starp 57 pacientiem ar spieḳkaula distālo galu lūzumiem 25 pacientiem (44 \%) 
tika konstatēti SLIL dažādas pakāpes bojājumi, 3 pacientiem (5 \%) LTIL bojājumi, bet 16 pacientiem (28 \%) konstatēti TFCC bojājumi (Roulet et al., 2020).

Interosālo saišu un TFCC bojājumu sastopamības biežums variē dažādos rakstos, bet vidēji tas svārstās robežās ap 50 \% TFCC bojājumiem un ap 30 \% SLIL bojājumiem (Ardouin et al., 2018). Jaunākos literatūras avotos ir atrodama arī detalizēta sīkāku mīksto audu struktūru bojājumu analīze, taču šīm atradnēm nav korelācijas ar klīniskajām atradnēm un ārstēšanas gala iznākumu. Klīniski svarīgi ir noteikt stabilizējošo struktūru bojājuma pakāpi, lai izvairītos no sekundāras karpālās nestabilitātes veidošanās, ja bojājumi nav pienācīgi izvērtēti. Šī nestabilitāte eventuāli var novest līdz SLAC (Scapho-lunate advance collapse) deformācijai un osteoartrītam.

W. B. Geissler, kurš ieviesa arī SLIL un LTIL bojājumu artroskopisko klasifikāciju, ieteica lietot imobilizāciju I pakāpes bojājumu ārstēšanā, transfiksāciju ar stieplēm II pakāpes bojājumiem, artroskopisku vai vaḷēju rekonstrukciju, papildus fiksējot ar stieplēm III pakāpes bojājumiem, savukārt IV pakāpes bojājumu ārstēšanā rekomendēja izvēlēties vaḷēju repozīciju un saites rekonstrukciju ar vai bez cīpslas transplantāta (Geissler, 2013; Peicha et al., 1999). Tik agresīva ķirurǵiskā pieeja daudziem rokas ķirurgiem tomēr nešķita pieņemama, kā arī iepriekš jau bija veikti citi pacientu novērojumi ar dažādas pakāpes SLIL bojājumiem, kuros saudzīgāka terapija arī deva apmierinošus un labus rezultātus. D. P. Forward ar līdzautoriem 2007. gadā publicēja prospektîva pētījuma rezultātus, kurā tika secināts, ka I un II pakāpes bojājumi, kurus ārstē tikai ar imobilizāciju, gada laikā pēc spieķkaula distālā gala lūzuma operācijas ir asimptomātiski (Forward et al., 2007). Imobilizācijas protokolu pēc lūzuma fiksācijas ar VLP vēlams pielāgot konkrētās operācijas laikā konstatētā SLIL bojājuma pakāpei (Ono et al., 2012). SLIL III pakāpes bojājumu fiksācijas metodes un ārstēšana joprojām ir pretrunīga. Vairāki autori piekrīt W. B. Geissler rekomendētajai SL locītavas transfiksācijai anatomiski korektā pozīcijā ar stieplēm III pakāpes bojājumu gadījumā (Kasapinova and Kamiloski, 2015; Khanchandani and Badia, 2013). Savukārt A. Mrkonjic ar līdzautoriem 2015. gadā publicēja ilgtermiṇa (13 līdz 15 gadu pēc primārās operācijas) novērojumu rezultātus, kuros starp I-II un III pakāpes SLIL bojājumiem netika konstatētas statistiski ticamas vai klīniskas subjektīvo, objektīvo un radiolog̣isko rezultātu atšķirības. Šādus rezultātus autoru kolektīvs izskaidro ar plaukstas sekundāro stabilizējošo struktūru (volāri - RSL, RSC un LRL saites, dorsāli - DRT un DIC saites) esamību un rekomendē nākotnē veikt papildu klīniskos pētījumus tieši šo stabilizatoru lomas noskaidrošanai. Akūti IV pakāpes SLIL bojājumi rada dinamisku karpālo nestabilitāti, un to ārstēšanā nepieciešama artroskopiska vai vaḷēja repozīcija, locītavas transfiksācija ar stieplēm vai stabilizācija ar enkura šuvēm (Lindau, 
2017). Artroskopiskās locītavas transfiksācijas gadījumā tiek rekomendēta arī artroskopiska kapsulodēzes procedūra, kura rada papildu stabilitāti stiepḷu fiksācijai (DelPinal F, 2010).

Distālās radioulnārās locītavas (DRUJ) stabilitāte arī ir būtisks faktors labu pēcoperācijas rezultātu sasniegšanā. TFCC kombinācijā ar interosālās membrānas distālo daḷu ir svarīgākā DRUJ stabilizējošā mīksto audu struktūra, kas nodrošina netraucētas apakšdelma kustības. TFCC mijiedarbība ar interosālās membrānas distālo daḷu nodrošina DRUJ stabilitāti jebkurā kustības fāzē (Haugstvedt et al., 2017; Moritomo, 2015). Eksperimenti ar anatomisko materiālu ir pierādījuši, ka ekstraartikulāro spieḳkaula distālā gala lūzumu gadījumā deformācija ar spieķkaula augstuma (radial shortening) saīsinājumu (Scheer and Adolfsson, 2012) vairāk par 4 mm, spieḳkaula distālā gala leṇķa (radial inclination) izlīdzināšanās līdz $0^{\circ}$ un dorsālā leṇķa deformācija (angulācija) virs $10^{\circ}$ (normāla volārā pārkare ir 15-25) vienmēr bojā TFCC savienojumu ar elkoṇkaula galviṇu. Artikulāro lūzumu gadījumos veidojas dažādas TFCC bojājumu kombinācijas, kā arī gados vecākiem pacientiem nereti novēro deǵeneratīvus bojājumus, kuri traumas brīdī kḷūst plašāki un simptomātiski.

T. Lindau ar kolēgiem 2000. gadā publicēja pētījumu, kurā tika demonstrēti 51 pacienta vecumā no 20 līdz 57 gadiem artikulāro distālo spieḳkaula lūzumu ārstēšanas rezultāti, akcentējot diagnosticēto TFCC perifēro bojājumu funkcionālos rezultātus vienu gadu pēc operācijas. Primārās artroskopiskās operācijas laikā tika konstatēti daḷêji TFCC perifērie bojājumi 43 pacientiem. Gadu pēc operācijas 10 pacientiem ar pilnu perifēro plīsumu un 7 pacientiem ar daḷēju perifēro plīsumu (kopā 39,5\%) tika konstatētas DRUJ nestabilitātes pazīmes, uzrādot sliktākus subjektīvos un objektīvos mērījumu rezultātus, salīdzinot ar pārējiem pacientiem (Lindau et al., 2000). Šis autoru kolektīvs pēc 15 gadiem publicēja atkārtotus konkrētās pacientu grupas apsekojuma rezultātus, kuros secināts, ka ķirurgiska DRUJ stabilizācija bija nepieciešama tikai 1 no 17 pacientiem (5,9\%) ar agrāk diagnosticēto DRUJ nestabilitāti. Iegūtais rezultāts liek secināt, ka perifērie TFCC bojājumi rada daudz mazāk klīnisko problēmu, nekā tika sagaidīts (Lindau, 2017).

Joprojām diskutabls ir jautājums par elkoṇkaula īlenveida izauguma (proc. styloideus ulnae) lūzuma veidu un tā saistību ar TFCC bojājumu un DRUJ nestabilitāti. Ir pieņēmums, ka elkoņkaula îlenveida izauguma pilna apjoma lūzumi ir saistāmi ar TFCC proksimālās daḷas iespējamu atdalīšanos no piestiprināšanās vietas pie elkoņkaula galviņas, radot DRUJ nestabilitāti. D. S. Ruch ar līdzautoriem 2003. gadā aprakstīja 13 TFCC proksimāla bojājuma simptomātisku gadījumu novēršanas rezultātus 57 pacientu grupā, kam tika veiktas artroskopiski asistētas osteosintēzes un arī TFCC perifēro bojājumu novēršana. Divu gadu laikā 12 no 13 operētajiem pacientiem tika konstatētas stabilas DRUJ bez subjektīviem DRUJ funkciju traucējumiem (Ruch et al., 2003). 
M. W. M. Fok ar līdzautoriem 2018. gadā veica pētījumu, kurā analizēja TFCC bojājumu raksturu un sastopamību pēc spieḳkaula distālo artikulāro lūzumu ārstēšanas ar VLP un to sadzīšanas. Pētījumā tika iekḷauti 43 pacienti ar vidējo vecumu 54 gadi (17 līdz 75 gadi), kuriem plānveida kārtā dažādu, bet ne septisku iemeslu dēḷ bija paredzēta implantu evakuācija. Veicot artroskopiju, mērḳtiecīgi tika izvērtēts TFCC bojājumu veids un tā saistība ar DRUJ nestabilitāti. DRUJ nestabilitāte un ulnārās puses sāpes, kuras ir statistiski ticami saistāmas ar TFCC bojājumu, tika konstatētas tikai 8 pacientiem (18,6\%), kuriem bija pilns proksimāls TFCC plīsums, respektīvi, pilns atrāvums no elkoṇkaula galviṇas (Fok et al., 2018).

A. C-Y. Chen 2018. gadā publicēja ilgstoša pētījuma rezultātus, kurā tika salīdzināti agrīnu (1 līdz 3 mēnešus pēc traumas) un vēlīnu (vairāk nekā 12 mēnešus pēc traumas) elkoņkaula īlenveida izauguma pilna apjoma lūzumu fiksācijas rezultāti. Autora secinājumi bija, ka pilna apjoma elkoņkaula îlenveida izaugumu lūzumi parasti ir saistîti ar TFCC proksimālās daḷas dažādu pakāpju bojājumiem, kuri rada sekundāru DRUJ nestabilitāti. Novēršot bojājumus iespējami agrāk, tiek radīti priekšnosacījumi labāku funkcionālo rezultātu sasniegšanai. Vēlīni veiktajās operācijās daudz biežāks ir nesaaugšanas un citu komplikāciju risks. Autori rekomendē pilna izmēra elkoņkaula īlenveida izaugumu lūzumu, kas asociējas ar DRUJ nestabilitāti, ārstēšanu veikt maksimāli ātri pēc traumas (Chen et al., 2018).

Mana pētîjuma ietvaros tika konstatēti dažādi asociētie bojājumi, kā arī veikta to novēršana gadījumos, kad šādas papildu manipulācijas bija nepieciešamas locītavu iespējamas nestabilitātes un sekojošas osteoartrozes riska samazināšanai. Abu grupu pacientiem šo asociēto bojājumu sastopamība statistiski būtiski neatšḳīās $(p=0,22)$, tāpēc tie atsevišḳi pa grupām netiek prezentēti. Sešpadsmit pacientiem (25\% no visiem) tika konstatēti SLIL dažādas pakāpes plīsumi (Geissler II-IV). Deviniem pacientiem (14 \% no visiem), kuriem bija Geissler IV pakāpes plīsumi, tika veikta artroskopiski asistēta S-L locītavas repozīcija un transfiksācija ar stieplēm. LTIL saitei tikai 6 pacientiem tika konstatēts Geissler II pakāpes bojājums, kas sakrīt ar iepriekš novēroto un literatūrā aprakstīto interkarpālo saišu traumu biežumu un smaguma pakāpi. SLIL IV pakāpes bojājumu fiksācijā mērḳtiecīgi tika izvēlēta mīkstos audus papildus mazāk traumējoša metode, taču ĀFA grupā tas radīja papildu stiepḷu ievadīšanas nepieciešamību, iespējami palielinot mīksto audu komplikāciju risku. Dažādi izolēti TFCC bojājumi tika konstatēti 11 pacientiem (17,1 \% no visiem), savukārt 8 pacientiem (12,5 \%) tika konstatēti kombinēti TFCC un SLIL bojājumi. Radiālo TFCC bojājumu ķirurǵiska likvidēšana netika veikta, jo no literatūras ir zināms, ka, veicot spieķkaula ulnārās puses fragmentu anatomisku repozīciju un fiksāciju, TFCC radiālās malas bojājumi nerada DRUJ nestabilitāti, kā arī tiem ir liels potenciāls saaugt (Fok et al., 2018). TFCC centrāliem bojājumiem, kuri teorētiski varēja būr arī deǵeneratīva rakstura, īpaši gados vecākiem pacientiem, tika veikta 
tikai bojājuma zonas malu nolīdzināšana. Ķirurğiska TFCC zonas stabilizācija veikta tikai pacientiem ar DRUJ nestabilitātes simptomiem, kuri saglabājās pēc spieḳkaula lūzuma osteosintēzes. Trim pacientiem (4,7 \% no visiem) tika veikta TFCC refiksācija artroskopiskā tehnikā ar atsevišķām uzsūcoša materiāla šuvēm pie dorsālās kapsulas, savukārt 7 pacientiem (10,9 \% no visiem) bija nepieciešama processus styloideus ulnae pamatnes lūzuma osteosintēze ar stieplēm un savelkošo cilpu.

\subsection{Rezultātu izvērtējums}

Tradicionāli plaukstas funkciju izvērtējumu pēc ķirurgisiskām manipulācijām veic, mērot kustību apjomu, kā arī satvēriena spēku. Abi mērījumi sniedz labu un objektīvu rezultātu atspoguḷojumu, taču šìm metodēm ir trūkums - tās nesniedz informāciju par citiem ārstēšanas aspektiem: pacienta sāpēm, spēju veikt dažādas ikdienas aktivitātes vai spēju atgriezties iepriekšējā darbā u. c. Šādu datu iegūšanai un to analizēšanai laika gaitā ir ieviestas dažādas funkcionālās skalas.

Šì pētījuma rezultātu fiksēšanai un vēlākai izvērtēšanai tika lietotas vairākas vispārpieņemtas un pārbaudītas datu registrācijas metodes. N̦emot vērā faktu, ka līdz šim brīdim rokas ḳirurg̣ijā vēl nav ieviesta unificēta datu fiksācijas sistēma spieḳkaula distālo galu lūzumu rezultātu izvērtēšanā, izvēelējos populārākās un plaukstas traumu izvērtēšanā rekomendētākās datu reg̣istrācijas metodes - Gartland \& Werley modificēto skalu un PRWE skalu, kurās ir iekḷauti gan pacienta subjektīvie sāpju un funkciju izvērtējumi, gan arī atsevišķu objektīvo radītāju reǵistrācija. Papildus izvēlējos izmantot arī MASS07 skalu, kurā iekḷauta mūsdien̄̄gu tehnologisko ierīču izmantošanas funkcionālo rādītāju reǵistrācija, kā, piemēram, datora klaviatūra, viedtelefons, elektriskās ierīces u.tml. Šīs īsās 10 jautājumu skalas lietošanu rekomendē arī $M$. Alexander ar kolēgiem, kuri pierādīja, ka tās statistiskā efektivitāte ir pielīdzināma DASH un PRWE skalām un tāpēc rekomendējama plaukstas locītavas funkcionālai izvērtēšanai pēc plaukstas traumām (Alexander et al., 2008).

S. Gupta ar kolēgiem ir publicējis rakstu, kurā savstarpēji salīdzinātas pētījumos visbiežāk izmantotās skalas DASH un PRWE. Autori secina, ka abu skalu iegūto rezultātu statistiskā analīze neuzrāda atšķirības. N̦emot vērā iepriekšminēto, kā arī faktu, ka PRWE skala ir plaukstas locītavas funkcijām specifiska atšķirībā no DASH, kura vairāk ir tendēta uz pleca un elkoņa locītavas funkciju izvērtēšanu, autori rekomendē PRWE skalu kā izvēles metodi plaukstas funkcionālo rezultātu reǵistrēšanai (Gupta et al., 2014).

J. F. Waljee ar līdzautoriem 2016. gadā publicēja analītisku rakstu par plaukstas locītavas ārstēšanas rezultātu atspoguļojumu medicīniskajā literatūrā, kā arī rekomendēja kopsavilkumu ar vēlamo datu minimumu, kuru varētu izmantot unificêtā datu analīzē un 
metaanalīzes pētījumos. Šis rekomendētais standarts iekḷauj abu roku simetrisko locītavu kustību apjoma mērījumus, plaukstas un pirkstu satvēriena spēka (Grip, Pinch, Tripod Pinch) mērījumus, pacienta subjektīvo sāpju un funkciju vizualizāciju (PRWE, MHQ - Michigan Hand Quuestionarry, PROMIS - Patient-Reported Outcomes Measurement Information System) skalas. Tāpat tajā iekḷauta konkrētu komplikāciju un to novēršanā veikto ārstēšanas manipulāciju reǵistrācija, kā arī radiologiisko datu fiksācija - kaula sadzīšanas pazīmes, locītavu virsmu raksturojums, deformāciju veidi un izmēri, metāla konstrukciju lokalizācija un iespējamās novietojuma vai izmēru kḷūdas, standarta parametru, t. i., volārās pārkares leṇķa, spieķkaula distālā gala garuma, radiālās inklinācijas leṇķa un elkoṇkaula / spieķkaula distālā gala, savstarpējā attiecība (ulna +/) (Waljee et al., 2016).

Šajā pētījumā tika izmantota arī radioloǵisko rezultātu reǵistrācija atbilstoši Gartland \& Werley skalā iekḷauto radioloǵisko parametru sadaḷai, kā arī plāksnes novietojums atbilstoši Soong kritērijiem.

Šì pētījuma ietvaros pacientu novērošanas laikā tika atklātas dažādas statistiski ticamas atšḳirības vairākos objektīvos un subjektīvos parametros, taču abu ḳirurǵisko ārstēšanas metožu salīdzinājumā iegūtajiem rezultātiem nav būtisku atšķirību klīniskajā izpratnē. VLP grupā tika novēroti labāki funkcionālās atveseḷošanās rādītāji īstermiṇā, taču 12 mēnešu laikā atškirirības starp abām novērojuma grupām izlīdzinājās un vairs netika konstatētas klīniskās atsḳirības. Būtiskā mērījumu rezultātu atšķirība vienu mēnesi pēc operācijas ir izskaidrojama ar diametrāli pretēju ārstēšanas metožu lietošanu. VLP grupas pacienti uzsāka rehabilitāciju ar trešo pēcoperācijas nedēlu, kas likumsakarīgi deva iespēju šīs grupas pacientiem daudz ātrāk atgriezties pie normālām ikdienas aktivitātēm, bet ĀFA grupas pacientiem fiksācija tika noṇemta četras nedēḷas pēc operācijas vai atsevišķos gadījumos stieples vēl tika atstātas kaulos ilgāku laiku. Ja izvērtējam pacientu emocionāli subjektīvo vērtējumu, tad VLP grupas pacientiem īstermiņā tas bija būtiski labāks, jo viṇi ātrāk atsāka traumētās plaukstas aktivitātes, bet 12 mēnešu periodā ne klīniski, ne subjektīvi būtiskas atšķirības starp grupām netika atrastas.

Tālāk sekojošās mainīgās statistiski ticamās atšķirības atsevišķos kustību apjoma mērījumu rezultātos varētu būt saistītas ar faktu, ka datu pierakstu veica trīs dažādi cilvēki un mērījumu veikšanā varētu nebūt ievērota identiska metodika. Neskatoties uz skaitlos matemātiski aprēḳinātām statistiski ticamām atšķirībām, šo atšḳirību klīniskais nozīmīgums ir apšaubāms (piem., $90 \%$ pret $97 \%$ no veselās plaukstas kustību apjoma 12 mēnešus pēc operācijas). Mans secinājums - visa pētījuma laikā, izņemot pirmo mēnesi pēc operācijas, starp abām grupām netika konstatētas klīniski nozīmīgas atšķirības. Ar šo tiek apgāzts hipotēzē izteiktais apgalvojums, ka minimāli invazīva ārstēšana varētu radīt iespējas sasniegt labākus funkcionālos rezultātus. 
Nākamais būtiskais diskusijas temats ir komplikāciju analīze. Biežākās spieķkaula distālā gala lūzumu un to ārstēšanas komplikācijas: locītavu rētaudu kontraktūras vai kustību ierobežojums; lūzumu sekundāra dislokācija ar nepareizu saaugšanu (malunion); metāla konstrukciju migrācija; cīpslu kairinājumi vai bojājumi; nervu kompresija vai bojājumi; sāpes vai kompleksais reǵionālo sāpju sindroms; infekcija.

Kopējais spieḳkaula distālā gala lūzumu komplikāciju skaits svārstās no 6 \% līdz $80 \%$ ar piebildi, kādi stāvokḷi tiek definēti kā komplikācijas (McKay et al., 2001). Veicot lūzumu fiksāciju ar jebkurām metāla konstrukcijām, ievērojami samazinās sekundāras dislokācijas un lūzuma nepareizas sadzīšanas iespējas. Liela daļa postoperatīvo komplikāciju var tikt novērstas operācijas laikā, ķirurgam fokusējoties uz operācijas metodiku un tehniskajām rekomendācijām, kā arī, ja nepieciešams, modificējot ķirurğisko tehniku individuāli katram pacientam (Rhee et al., 2012).

Veicot spieķkaula distālā gala lūzumu osteosintēzi ar plāksni un skrūvēm, viens no būtiskiem jautājumiem ir izvairīties no plāksnes novietošanas pārāk distāli, t. i., vēlams ievērot Soong kritērijus un novietot plāksnes distālo malu tā, lai tā nekairinātu saliecējcīpslas (Soong 0 pozīcija).

C. A. Selles ar kolēgiem 2018. gadā publicēja pētījuma rezultātus, kuros izvērtēja plākšṇu evakuācijas nepieciešamības gadījumus 323 pacientu grupā. Konstrukciju evakuācija kopumā bija nepieciešama 17 \% pacientu. Šajā grupā galvenokārt ietilpa pacienti ar augstāku Soong klasifikācijas pakāpi (I vai II). Soong II pakāpes plākšṇu novietojuma gadījumos to evakuācija bija nepieciešama sešas reizes biežāk, nekā Soong 0 pakāpes gadījumos. Šie rezultāti liek secināt, ka, precīzi pozicionējot plāksni, samazinās cīpslu bojājumu un metāla konstrukciju izṇemšanas nepieciešamība (Selles et al., 2018). Arī citi autori atzīmē plāksnes novietojuma Soong klasifikācijas augstākas pakāpes pierādītu saistību ar saliecējcīpslu komplikāciju risku un plāksnes evakuācijas nepieciešamību (Lutsky et al., 2015; Soong et al., 2011).

Vēl viena būtiska jatrogēna komplikācija ir atliecējcīpslu kairinājums vai bojājums ar pārāk garām skrūvēm, īpaši distālajā metafīzē. Šādi bojājumi satopami no $3 \%$ līdz $5 \%$ pacientu, kuriem veiktas spieḳkkaula distālo galu lūzumu osteosintēzes (Soong et al., 2011). Atliecējcīpslu dažāda rakstura bojājumi var veidot līdz pat $57 \%$ no visām iespējamām komplikācijām (Arora et al., 2007).

Manā pētijumā nevienam pacientam VLP grupā netika konstatētas ar cīpslu kairinājumu vai bojājumu saistītas komplikācijas, kā arī netika veikta plākšņu evakuācija. Visas plāksnes tika ievietotas Soong $O$ vai $I$ pakāpes pozīcijā - 10 pacientiem $(29,4 \%)$ Soong I un 24 pacientiem (70,6 \%) Soong 0 pozīcijā. Papildus fragmentu fiksācijai ievietotās stieples tika evakuētas lokālā anestēzijā fluoroskopijas kontrolē vai arī bez tās, ja stieples bija palpējamas 
zemādā. Ar stiepḷu ievietošanu saistītas cīpslu komplikācijas netika fiksētas. VLP grupas 3 pacientiem (4,7\% no visiem) tika konstatētas papildus ievietoto stieplu migrācijas. Šī nenozīmīgā komplikācija saistāma ar pacientu aktivizēšanu, sākot ar 3. pēcoperācijas nedēlu, ka rezultātā atsevišḳas stieples zaudēja primāro stabilitāti. Nevienā gadījumā stiepḷu izkustēšanās neradīja lūzuma fragmentu sekundāru dislokāciju, bet tikai kairināja apkārtējos audus, radot diskomforta vai mērenu sāpju sajūtu pacientiem. Pēc stiepḷu evakuācijas visas ar tām saistītās sūdzības izzuda.

F. Schuind klīniskajā pētījumā ar ĀFA lietošanu spieḳkaula distālo artikulāro lūzumu gadījumos apraksta komplikācijas un to sastopamības biežumu - 2. delnas (metakarpālā) kaula lūzums vītnstieṇa implantācijas vietā 1,6\%, karpālā tuneḷa sindroms 2,6 \%, radiālā nerva sensorā zara neirinoma 2,1 \%, sekundāra fragmentu dislokācija ar būtisku sakotnējā fragmentu stāvokḷa izmaiṇu 2,1\%, stiepḷu infekcija 12,8 \% un kompleksais reǵionālo sāpju sindroms (CRPS) 0,8 \% (Schuind et al., 1989). Manā pētījumā ĀFA grupā radiālā nerva dorsālā sensorā zara bojājuma iemesls, visticamāk, bija multiplu stiepḷu lietošana primārās repozīcijas laikā vai arī vairāku papildu stiepḷu ievadīšana caur 1-2 portālu artroskopiskās papildu repozīcijas un fragmentu fiksācijas laikā. Tas liek secināt, ka daudzu stiepḷu lietošanas un atkārtotu transkutānu manipulāciju laikā pieaug nerva bojājuma risks. Manā pētījumā diviem pacientiem (3,1\% no visiem) ĀFA grupā tika novērota arī sekundāra kaulu fragmentu dislokācija pēc fiksācijas izṇemšanas un kustību iestrādes uzsākšanas. Šī komplikācija saistāma ar iespējamu nepiln̄̄gas konsolidācijas izveidošanos starp multipliem locītavas virsmas fragmentiem, ko būtu iespējams novērst, atstājot stieples subhondrālajā kaula slānī vai starp fragmentiem uz ilgāku periodu. Diemžēl, veicot kontroles rentgenogrammas 4 līdz 6 nedēlas pēc operācijas, kaula rumbējuma kvalitāte tiek izvērtēta tikai vizuāli, kas atsevišķos gadījumos var būt maldinoša un vēlākā ārstēšanas periodā izraisīt lūzuma zonas deformāciju. Jāpiemin, ka šī konkrētā komplikācija tika konstatēta pacientiem ar AO - C3 veida lūzumiem, kuri sastāvēja no četriem vai vairāk locītavas virsmas fragmentiem. Tas liek secināt, ka īpaši šķembainu spieḳkaula distālo galu lūzumu gadījumos, neskatoties uz samērā precīzo fragmentu repozīciju un fiksāciju artroskopijas kontrolē, pacienta aktivizācijas periodā pēc fiksatoru izṇemšanas ir iespējamas atsevišķu fragmentu sekundāras nobīdes.

Abas osteosintēzes metodes bija vienlīdz viegli lietojamas $\mathrm{AO}-\mathrm{C} 1$ veida lūzumu ārstēšanā, savukārt vairāk fragmentēto AO - C3 veida lūzumu ārstēšana bija daudz sarežğîtāka un netika novērotas vienas vai otras metodes priekšrocības. Salīdzinoši augstais papildu repozīciju skaits operācijas artroskopiskā etapa laikā liek secināt, ka šķembainu artikulāro lūzumu gadījumos ar četriem un vairākiem artikulāriem fragmentiem ir grūti panākt optimālu fragmentu stāvokli bez artroskopiskās kontroles. Primārā repozīcija un fiksācija ar vairākām 
stieplēm nenodrošina tikpat lielu stabilitāti un ekstraartikulārās kaula daḷas kontūras atjaunošanu kā volārā bloḳētā plāksne. Domāju, ka tieši šī iemesla dēl ĀFA grupas diviem pacientiem tika novērota reponēto kaula fragmentu sekundāra dislokācija.

Vēl viena perifēro nervu iespējamā komplikācija spieḳkaula distālo lūzumu gadījumos ir akūts karpālā tuneḷa sindroms, kurš rodas $n$. Medianus kontūzijas vai posttraumatiskās tūskas radītās kompresijas rezultātā. Pacientiem ar n. Medianus akūta bojājuma simptomiem tiek rekomendēta karpālās saites šķelšana un neirolīze, ja simptomi neizzūd pēc primāras repozīcijas un lūzuma fiksācijas ğipša pārsējā vai neatliekamā ĀFA fiksācijā. Manā pētîjumā nevienam pacientam pēc primārās repozīcijas veikšanas $n$. Medianus kompresijas vai kontūzijas simptomi netika konstatēti, tāpēc operāciju laikā karpālās saites šķelšana un nerva vizualizācija karpālajā tunelī netika veikta. Pēc literatūras datiem, profilaktiskas karpālā tuneḷa atbrīvošanas manipulācijas rezultāti ir pretrun̄̄gi - ir autori, kuri apgalvo, ka šī manipulācija var palielināt nevajadzīgu komplikāciju risku (Lattmann et al., 2008; Odumala et al., 2001). Pretēju viedokli var atrast publikācijās, kurās autori apraksta operāciju sērijas ar standartizēti veiktu karpālās saites šḳelšanu visiem pacientiem bez komplikācijām (Gwathmey et al., 2010; Khanchandani and Badia, 2013). N̦emot vērā, ka nav sastopami randomizēti pētījumi par karpālās saites šķelšanu asimptomātiskiem pacientiem, veicot spieḳkaula lūzumu osteosintēzes ar plāksnēm, tad pagaidām šîs manipulācijas veikšana vai atturēšanās no tās tiek rekomendēta pēc operējošā ķirurga ieskatiem (Seigerman et al., 2019).

Viena no smagākajām un grūtāk ārstējamām komplikācijām ir kompleksais reǵionālo sāpju (Zudeka) sindroms (CRPS). Tas var attīstīties gan konservatīvas, gan ḳirurǵiskas ārstēšanas rezultātā. Šī sindroma klīniskās izpausmes ir sāpes un objektīva simpātiskās nervu sistēmas disfunkcija - tūska, locītavu stīvums, iesaistītās ekstremitātes krāsas izmaiņas un vazomotori traucējumi, kā hiperhidroze un allodīnija. CRPS sastopamība ir no 1 līdz $37 \%$ spieḳkaula distālo galu lūzuma pacientu, un tā parādīšanās biežāk ir novērojama multifragmentāru vai augstas enerğijas traumas rezultātā gūtu lūzumu gadījumos (Dijkstra et al., 2003; Jellad et al., 2014), kā arī incidence gados vecākām sievietēm ir 3 līdz 4 reizes lielāka nekā vīriešiem (Patterson et al., 2011). CRPS ārstēšanā tiek rekomendēta kompleksa terapija, kurā ir iekḷauti pretsāpju medikamenti, intensīva ergoterapija, intravenozas steroīdu injekcijas, antidepresanti, atsevišķos gadījumos ganglion stellatum blokādes, kā arī psiholoǵiskā un / vai psihiatriskā palīdzība, ja nepieciešams. Manā pētījumā CRPS tika konstatēts vienai pacientei (1,6\% no visiem) vecuma grupā virs 60 gadiem, kurai iniciālas CRPS pazīmes jau novērotas pirms operācijas - pārāk cieša imobilizācija, psiholoǵiska predispozīcija un salīdzinoši ilgs laiks (divas nedēḷas pēc primārās traumas) līdz operācijai. Rīkojoties atbilstoši literatūrā rekomendētajam CRPS ārstēšanas algoritmam, simptomu remisija tika panākta sešu mēnešu 
laikā pēc operācijas. Panāktais rezultāts atbilst medicīniskajā literatūrā publicētajiem CRPS ārstēšanas rezultātiem, paciente spēja atgriezties iepriekšējā aktivitāšu līmenī, lai gan pilnu kustību apjomu un satvēriena spēku atgūt nespēja.

N̦emot vērā, ka š̄ pētījuma būtiskākā sastāvdaḷa ir plaukstas artroskopija, tad nākamajā diskusijas sadaḷā pievērsīšos iespējamām komplikācijām, kuras var radīt šī miniinvazīvā ķirurǵiskā tehnika. C. Leclercq ar kolēǵiem 2016. gadā publicēja 36 rokas ķirurǵijas centru plaukstas artroskopiju komplikāciju apkopojumu, iekḷaujot 10107 artroskopisko operāciju rezultātus. Kopumā tika registrētas 605 dažādas ķirurǵiskās komplikācijas (5,98 \%). Kā biežākās no komplikācijām tika definētas nespēja veikt ieplānoto procedūru artroskopiski $(1,16 \%)$ un jatrogēnie nervu bojājumi portālu izveidošanas vietās $(1,17 \%)$. Autoru kolektīvs secināja, ka komplikācijas retāk rodas ķirurgiem, kuri veic vairāk nekā 25 artroskopiskās operācijas gadā un kuru pierdze šādu manipulāciju veikšanā ir vismaz pieci un vairāk gadi (Leclercq et al., 2016). Manā pētījumā netika konstatēta neviena komplikācija, kuras iemesls būtu artroskopiskā operācijas tehnika. Pētījuma grupās nevienam pacientam neradās infekcijas izraisītas komplikācijas, ko var saistīt ar standarta perioperatīvo antibakteriālo profilaksi, operāciju zālē intravenozi ievadot 2 g cefazolīna tieši pirms ķirurğiskās manipulācijas sākuma.

Šim pētījumam ir arī vairāki ierobežojumi. Lai maksimāli ātri piepildītu abas pētījuma grupas ar vienādu pacientu skaitu, tika izvēēēta randomizācija ar alternatīvās allokācijas metodi. Atsevišķos gadījumos izvēlētā metode neḷāva veikt optimālo fragmentu fiksāciju. Iespējams, ka nespēja izvēēêties konkrētā lūzuma konfigurācijai labāko vai ķirurgam ērtāko ārstēšanas metodi tika radīti papildu tehniskie apgrūtinājumi un ārstēšanas gala rezultāts šādā veidā tika negatīvi ietekmēts. Diemžēl ar statistiskās analīzes metodēm šo apgalvojumu pierādīt konkrētā pētījuma ietvaros nebija iespējams. Daḷai VLP grupas pacientu papildu fragmentu fiksācijai tika izmantotas stieples, jo osteosintēze tikai ar plāksni un skrūvēm neḷāva veikt stabilu visu lūzuma fragmentu fiksāciju, lai gan fluoroskopiski š̄i nestabilitāte nebija verificējama. Šì konkrētā informācija vēlreiz apstiprina artroskopijas nepieciešamību artikulāru spieķkaula distālā gala lūzumu ārstēšanā.

Kopumā divu gadu laikā tika veiktas 74 operācijas (38 operācijas VLP grupā un 36 operācijas ĀFA grupā). Četri pacienti VLP grupā un seši pacienti ĀFA grupā dažādu iemeslu dēḷ neieradās uz visām novērošanas protokolā paredzētajām vizìtēm. Viṇu dati netika iekḷauti galējā analīzē, un man nav iespējas izvērtēt viņu rezultātus. Atsevišķos gadījumos pacientu objektīvo datu pierakstu nācās veikt man pašam vai kādam citam ķirurgam, jo ergoterapeites noslogojums nepiel̦āva veikt papildu darbus. 
Veicot operācijas pēc vienotas sistēmas un ordinējot rehabilitāciju pie vienas un tās pašas ergoterapeites, tika nodrošināti vienlīdzīgi ārstēšanas apstākḷi visiem pacientiem. Abas pētījuma grupas bija izveidotas līdzvērtīgas. Pētījumā tika izslēgta iespēja ārstniecības metodi izvēlēties pēc pacienta vecuma, dzimuma vai lūzuma veida. Tika iegūtas kombinācijas ar dažāda vecuma pacientiem, kuriem ir dažādu pakāpju lūzumi un kuri tiek ārstēti gan ar ĀFA un stieplēm, gav ar volāro bloḳēto plāksni.

Lietojot ĀFA un stieples, tika novērots lielāks komplikāciju skaits, nekā veicot lūzumu ārstēšanu ar volāro bloḳēto plāksni, un to novēršanai bija nepieciešama ķirurğiskā ārstēšana (nervu bojājumi). ĀFA grupas pacientiem tika konstatētas arī sekundāras lūzuma fragmentu deformācijas, kas rezultātā nākotnē var radīt posttraumatisku deformējošo osteoartrozi.

Iegūtie rezultāti nesniedz neapgāžamus pierādījumus vienas vai otras ārstēšanas metodes priekšrocībām, taču apstiprina, ka abas metodes ir lietojamas dažāda vecuma pacientiem. Izvirzītā hipotēze, ka ĀFA un stiepḷu fiksācija kombinācijā ar plaukstas locītavas artroskopiju spieḳkaula distālo artikulāro lūzumu ārstēšanā ir labāka par fiksāciju ar VLP artroskopijas kontrolē, diemžēl neapstiprinājās. Izvēle par labu jebkurai no šìm metodēm ir jāveic, ņemot vērā lūzuma ǵeometriju, ārsta pieredzi un tehniskās iespējas.

Iespējams, statistiski ticamas atšḳirības starp abām grupām varētu iegūt, palielinot pētāmo grupu lielumus. 


\section{Secinājumi}

1. Veicot randomizēto pacientu grupu pēcoperācijas radiologísko un funkcionālo rezultātu izvērtēšanu, balstoties uz pacientu dzīves kvalitātes un veselības stāvokḷa izvērtējumu (Gartland and Werley, PRWE un MASS07 skalas), kustību apjoma un spēka mērījumiem, kā arī veiktajām Rtg kontrolēm 1, 3, 6 un 12 mēnešus pēc operācijas, konstatēts, ka novērojumu perioda sākumā labākus funkcionālos rādītājus atsevišḳos parametros uzrādīja VLP grupas pacienti. 12 mēnešu periodā būtiskas un statistiski ticamas atškirīibas starp grupām vairs netika konstatētas, kas norāda uz faktu, ka abas ārstēšanas metodes ir piemērojamas konkrēto lūzumu ārstēšanā. Mazāk invazīvāa ārstēšana ar ĀFA un stieplēm artroskopijas kontrolē nav pierādījusi prognozēto pārākumu pār vaḹeju osteosintēzi un fiksāciju ar VLP artroskopijas kontrolē.

2. Veicot abu grupu pacientu komplikāciju analīzi, tika konstatētas četras komplikācijas VLP grupā (11,8\% no grupas pacientu skaita), kāa arī četras komplikācijas ĀFA grupā (13,3\% no kopējā grupas pacientu skaita).

Komplikāciju skaits abās grupās bija neliels, un tās visas tika atrisinātas novērojuma laikā, taču ĀFA grupā tās ir uzskatāmas par būtiskākām. Ar ķirurǵisko tehniku saistîtas komplikācijas tika novērotas tikai ĀFA grupā, kurā, lietojot lielu stiepḷu daudzumu fragmentu fiksācijai artroskopijas kontrolē, tika novēroti $n$. radialis dorsālo ādas zaru jatrogēni bojājumi, kuru novēršanai bija nepieciešama ḳirurğiska iejaukšanās.

ĀFA grupā diviem pacientiem tika novērota arī sekundāra locītavas virsmas fragmentu dislokācija pēc stiepḷu evakuācijas un ĀFA demontāžas, kas liecina, ka atsevišķos gadījumos implantu (VLP) ilgstoša atstāšana kaulā ir būtiska, lai nodrošinātu stabilitāti arī lēnākas konsolidācijas gadījumos.

Ṇemot vērā lielāku komplikāciju skaitu ĀFA grupā, jāsecina, ka ĀFA un daudzu stiepḷu lietošanai spieḳkaula distālo galu artikulāro lūzumu ārstēšanā nav pierādāmu priekšrocību, izṇemot gadījumus, kad fiksācija ar VLP nav tehniski iespējama.

Papildus fiksācijā izmantoto stiep̣̣u migrācija atsevišḳos gadījumos VLP grupā saistāma ar agrīnu aktīvo kustību iestrādi. Šì nelielā komplikācija nav radījusi sekundāras kaula fragmentu dislokācijas vai kādu mīksto audu struktūru bojājumus nevienam pacientam.

3. Analizējot artroskopijas lietderību abās grupās, konstatēts, ka locìtavas artikulāro fragmentu papildu repozīcija operācijas artroskopiskajā etapā bija nepieciešama 46 gadījumos - 20 pacientiem (59 \%) VLP grupā un 26 pacientiem (87\%) ĀFA grupā, kas norāda, ka bez artroskopijas nebūtu novērsta intraartikulārā dislokācija, līdz ar to šādiem sarežğîtiem lūzumiem tā ir absolūti nepieciešama. 
Artroskopiskā etapa laikā tika konstatēti arī intraartikulāro mīksto audu struktūru bojājumi - SLIL, LTIL un TFCC bojājumi, kuri tika novērsti ar dažādām papildu manipulācijām. Neveicot artroskopiju, šie bojājumi paliktu nediagnosticēti un potenciāli pasliktinātu gan objektīvos, gan subjektīvos pacientu rādītājus ilgtermiṇā.

4. Pêtījuma rezultātā radītais algoritms artikulāro spieḳkaula distālā gala lūzumu ārstēšanas metožu izvēlei palīdzēs ortopēdiem ne tikai Latvijā, bet arī pasaulē izvēlēties artroskopijas metodes lietošanas nepieciešamību noteiktu lūzumu gadījumos un organizēt pacientu plūsmu, kam ir nepieciešama šī artroskopiski asistētā ķirurgiskāārstēšana.

5. Pētījuma rezultātā izveidots arī rekomendēto pēcoperācijas novērojumu un rezultātu monitorēšanas pasākumu algoritms, kas lietojams ne tikai spieḳkaula distālo galu lūzumu, bet arī plaukstas locītavas traumu vai ortopēdisko saslimšanu ārstēšanas rezultātu apkopošanai. Rekomendētais pasākumu komplekss bez papildu speciālas aparatūras izmantošanas ir lietojams jebkurā traumatolog̣ijas un ortopēdijas stacionārā Latvijā. Iegūtie dati varētu tikt izmantoti turpmāko klīnisko un akadēmisko pētījumu unificētai veikšanai. 


\section{Publikācijas un ziṇojumi par promocijas darba tēmu}

1. Funkcionālo rezultātu salīdzinājums pēc tradicionālās un artroskopiski asistētās spieḳkaula distālā gala artikulārā lūzuma osteosintēzes. Uldis Krustiņšs, Andris Jumtiņ̌̌, Diāna Bringina, Kristīne Šitca. https://www.rsu.lv/zinatniskie-raksti/funkcionalo-rezultati-pec-spiekkaula-distalagala-artikulara-luzuma-osteosintezes

2. Krustins, U., Krustins, J., Bringina, D., Laurane, K., Jumtins, A. Comparison of volar locking plates with external fixation and k-wires in arthroscopically assisted intra-articular distal radial fracture fixation. J Hand Surg Eur Vol. 2020, Vol. 45(4) 333-338. DOI: 10.1177/1753193419879567.

3. Comparison of fluoroscopically and arthroscopically assisted volar plating of articular distal radius fractures. Uldis Krustins, Vadims Nefjodovs, Diana Bringina, Aija Jaudzema, Andris Jumtins; PROCEEDINGS OF THE LATVIAN ACADEMY OF SCIENCES. Section B, Vol. 75 (2021), No. 1 (730), pp. 20-30. DOI: 10.2478/prolas-2021-00XX.

\section{Mutiskās prezentācijas un stenda referāti kongresos:}

1. 2011. g. ILTOK 2011, Rīga, Latvija - "Plaukstas artroskopija - pirmo 25 gadījumu analīze".

2. 2012. g. ILTOK 2012, Rīga, Latvija - "Spieḳkaula distālo artikulāro lūzumu ārstēšanas iespējas, izmantojot plaukstas artroskopiju".

3. 2012. g. 2nd Baltic hand Surgery Meeting 2012 Riga, Latvia - Arthroscopically assisted treatment of the distal radius fractures.

4. 2013. g. Joint Singapore - Malaysia - Finland - Estonia - Latvia Hand Surgery Societies Meeting (incorporating the 22nd Comprehensive Hand Review Course), Singapore - Arthroscopically Assisted Treatment of Mutilated Distal Radius Fractures.

5. 2013. g. Joint Singapore - Malaysia - Finland - Estonia - Latvia Hand Surgery Societies Meeting (incorporating the 22nd Comprehensive Hand Review Course), Singapore - Arthroscopical Debridement of Stiff Joints after Distal Radius Fractures.

6. 2013. g. AOTrauma seminar, faculty national, Riga, Latvia - Technical principles of the arthroscopic treatment of the distal radius fractures.

7. 2013. g. 5th Baltic Congress of Traumatology and Orthopaedics Riga, Latvia - The role of arthroscopic debridement as a second stage procedure after articular distal radius fractures.

8. 2014. g. 10th Congress of APFSSH, Kuala Lumpur, Malaysia stenda referāts - 5 year follow-up after bilateral articular distal radius fractures.

9. 2016. g. 26th SSSH Congress, Levi, Finland - Functional outcomes after artroscopically assisted and traditional surgical treatment of displaced articular distal radius fractures.

10. 2017. g. EWAS wrist arthroscopy course St. Petersburg, Russia - Wrist from inside - basic principles of the wrist arthroscopy.

11. 2017. g. 11th APFSSH Congress Cebu, Phillippines - Arthroscopic vs. nonarthroscopic treatment of distal radius fractures - evaluation of outcomes.

12. 2017. g. 11th APFSSH Congress Cebu, Phillippines stenda referāti - Arthroscopically assisted intra-articular distal radius fracture surgery with volar locking plates or external fixator and $K$-wires. Early results of ongoing study; Krukenberg procedure completed by two microvascular flaps to save functionality and length of the amputation stem. A case report.

13. 2018. g. Wrist. Practical Arthroscopy course. St. Petersburg, Russia - Wrist central column pathology.

14. 2019. g. Rīga Stradiņš University International Conference - Arthroscopic treatment and bone grafting of scaphoid nonunions. 
15. 2019. g. EWAS wrist arthroscopy course with training on anatomical specimen St. Petersburg, Russia - Clinical evaluation of TFCC injuries.

16. 2019. g. EWAS wrist arthroscopy course with training on anatomical specimen St. Petersburg, Russia - Ulnocarpal impingement and TFCC tears.

17. 2019. g. EWAS wrist arthroscopy course with training on anatomical specimen St. Petersburg, Russia - SLIL normal function, physiology and disfunction.

18. 2019. g. 27th SSSH Congress Tallinn, Estonia - Arthroscopy in Distal Radius Fractures.

19. 2020. g. 12th APFSSH Congress, Melbourne, Australia - Comparison of Functional Outcomes in Limited Carpal Fusions and Proximal Row Carpectomy.

20. 2020. g. 12th APFSSH Congress, Melbourne, Australia - Comparison of volar locking plates with external fixation and $K$-wires in arthroscopically assisted intra-articular distal radial fracture fixation; stenda referāts - Long term follow-up after microsurgical reconstruction of the humerus with two vascularized bone grafts.

21. 2020. g. Arthrex Online Webinar - Why is it important to eliminate intra-articular displacement? How do I do this with an acute and incorrectly fused distal radius fracture.

22. 2021. g. EOF Online Club Webinar - Acute scaphoid fractures.

23. 2021. g. 10th Congress of BAS, Riga, Online - Arthroscopically assisted treatment of distal radius fractures: 10 year experience of the single centre. 


\section{Literatūras saraksts}

1. Abe, Y. Plate presetting and arthroscopic reduction technique (part) for treatment of distal radius fractures. Handchir Mikrochir Plast Chir. 2014, 46: 278-85.

2. Abe, Y., Fujii, K. Arthroscopic-assisted reduction of intra-articular distal radius fracture. Hand Clin. 2017, 33: 659-668.

3. Alexander, M., Franko, O. I., Makhni, E. C., Zurakowski, D., Day, C. S. Validation of a modern activity hand survey with respect to reliability, construct and criterion validity. J Hand Surg Eur Vol. 2008, 33: 653-660.

4. Almedghio, S., Arshad, M. S., Almari, F., Chakrabarti, I. Effects of ulnar styloid fractures on unstable distal radius fracture outcomes: A systematic review of comparative studies. $J$ Wrist Surg. 2018, 7: 172-181.

5. Ardouin, L., Durand, A., Gay, A., Leroy, M. Why do we use arthroscopy for distal radius fractures? Eur J Orthop Surg Traumatol. 2018, 28: 1505-1514.

6. Arora, J., Malik, A. C. External fixation in comminuted, displaced intra-articular fractures of the distal radius: Is it sufficient? Arch Orthop Trauma Surg. 2005, 125: 536-540.

7. Arora, R., Lutz, M., Hennerbichler, A., Krappinger, D., Espen, D., Gabl, M. Complications following internal fixation of unstable distal radius fracture with a palmar locking-plate. J Orthop Trauma. 2007, 21: 316-322.

8. Atzei, A., Luchetti, R. Foveal tfcc tear classification and treatment. Hand Clin. 2011, 27: 263-272.

9. Auge, W. K. 2nd, Velazquez PA. The application of indirect reduction techniques in the distal radius: The role of adjuvant arthroscopy. Arthroscopy. 2000, 16: 830-835.

10. Bain, G. I., Alexander, J. J., Eng, K., Durrant, A., Zumstein, M. A. Ligament origins are preserved in distal radial intraarticular two-part fractures: A computed tomography-based study. J Wrist Surg. 2013, 2: 255-262.

11. Bain, G. I., MacLean, S. B. M., McNaughton, T., Williams, R. Microstructure of the distal radius and its relevance to distal radius fractures. J Wrist Surg. 2017, 6: 307-315.

12. Baumbach, S. F., Synek, A., Traxler, H., Mutschler, W., Pahr, D., Chevalier, Y. The influence of distal screw length on the primary stability of volar plate osteosynthesis - a biomechanical study. J Orthop Surg Res. 2015, 10: 139.

13. Boyer, M. I., Korcek, K. J., Gelberman, R. H., Gilula, L. A., Ditsios, K., Evanoff, B. A. Anatomic tilt x-rays of the distal radius: An ex vivo analysis of surgical fixation. J Hand Surg Am. 2004, 29: $116-122$.

14. Burnier, M., Le Chatelier Riquier, M., Herzberg, G. Treatment of intra-articular fracture of distal radius fractures with fluoroscopic only or combined with arthroscopic control: A prospective tomodensitometric comparative study of 40 patients. Orthop Traumatol Surg Res. 2018, 104: 89-93.

15. Catalano, L. W., 3rd, Barron, O. A., Glickel, S. Z. Assessment of articular displacement of distal radius fractures. Clin Orthop Relat Res. 2004: 79-84.

16. Changulani, M., Okonkwo, U., Keswani, T., Kalairajah, Y. Outcome evaluation measures for wrist and hand: Which one to choose? Int Orthop. 2008, 32: 1-6.

17. Chen, A. C., Chan, Y. S., Yuan, L. J., Ye, W. L., Lee, M. S., Chao, E. K. Arthroscopically assisted osteosynthesis of complex intra-articular fractures of the distal radius. J Trauma. 2002, 53: 354-359.

18. Chen, A. C., Chiu, C. H., Weng, C. J., Chang, S. S., Cheng, C. Y. Early and late fixation of ulnar styloid base fractures yields different outcomes. J Orthop Surg Res. 2018, 13: 193.

19. Colles, A. Historical paper on the fracture of the carpal extremity of the radius (1814). Injury. 1970, 2: 48-50. 
20. Costa, M. L., Achten, J., Parsons, N. R. et al. Percutaneous fixation with kirschner wires versus volar locking plate fixation in adults with dorsally displaced fracture of distal radius: Randomised controlled trial. BMJ. 2014, 349: g4807.

21. Del Pinal, F. Technical tips for (dry) arthroscopic reduction and internal fixation of distal radius fractures. J Hand Surg Am. 2011, 36: 1694-1705.

22. Del Pinal, F., Studer, A., Thams, C., Moraleda, E. Sigmoid notch reconstruction and limited carpal arthrodesis for a severely comminuted distal radius malunion: Case report. J Hand Surg Am. 2012, 37: 481-485.

23. Del Pinal, F., Luchetti, R., Arthroscopic management of distal radius fractures. Berlin Springer Verlag, 2010.

24. Dijkstra, P. U., Groothoff, J. W., Ten Duis, H. J., Geertzen, J. H. Incidence of complex regional pain syndrome type i after fractures of the distal radius. Eur J Pain. 2003, 7: 457-462.

25. Doi, K., Hattori, Y., Otsuka, K., Abe, Y., Yamamoto, H. Intra-articular fractures of the distal aspect of the radius: Arthroscopically assisted reduction compared with open reduction and internal fixation. J Bone Joint Surg Am. 1999, 81: 1093-1110.

26. Dunning, C. E., Lindsay, C. S., Bicknell, R. T., Patterson, S. D., Johnson, J. A., King, G. J. Supplemental pinning improves the stability of external fixation in distal radius fractures during simulated finger and forearm motion. J Hand Surg Am. 1999, 24: 992-1000.

27. Duramaz, A., Bilgili, M. G., Karaali, E., Bayram, B., Ziroglu, N., Kural, C. Volar locking plate versus $\mathrm{k}$-wire-supported external fixation in the treatment of ao / asif type $\mathrm{c}$ distal radius fractures: A comparison of functional and radiological outcomes. Ulus Travma Acil Cerrahi Derg. 2018, 24: $255-262$.

28. Edwards, C. C., 2nd, Haraszti, C. J., McGillivary, G. R., Gutow, A. P. Intra-articular distal radius fractures: Arthroscopic assessment of radiographically assisted reduction. J Hand Surg Am. 2001, 26: 1036-1041.

29. Esposito, J., Schemitsch, E. H., Saccone, M., Sternheim, A., Kuzyk, P. R. External fixation versus open reduction with plate fixation for distal radius fractures: A meta-analysis of randomised controlled trials. Injury. 2013, 44: 409-416.

30. Farah, N., Nassar, L., Farah, Z., Schuind, F. Secondary displacement of distal radius fractures treated by bridging external fixation. J Hand Surg Eur. Vol. 2014, 39: 423-428.

31. Fernandez, D. L., Geissler, W. B. Treatment of displaced articular fractures of the radius. J Hand Surg Am. 1991, 16: 375-384.

32. Fok, M. W. M., Fang, C. X., Lau, T. W., Fung, Y. K. E., Fung, B. K. K., Leung, F. K. L. The status of triangular fibrocartilage complex after the union of distal radius fractures with internal plate fixation. Int Orthop. 2018, 42: 1917-1922.

33. Forward, D. P., Lindau, T. R., Melsom, D. S. Intercarpal ligament injuries associated with fractures of the distal part of the radius. J Bone Joint Surg Am. 2007, 89: 2334-2340.

34. Franceschi, F., Franceschetti, E., Paciotti, M., Cancilleri, F., Maffulli, N., Denaro, V. Volar locking plates versus k-wire / pin fixation for the treatment of distal radial fractures: A systematic review and quantitative synthesis. Br Med Bull. 2015, 115: 91-110.

35. Freeland, A. E., Geissler, W. B. The arthroscopic management of intra-articular distal radius fractures. Hand Surg. 2000, 5: 93-102.

36. Frykman, G. Fracture of the distal radius including sequelae - shoulder-hand-finger syndrome, disturbance in the distal radio-ulnar joint and impairment of nerve function. A clinical and experimental study. Acta Orthop Scand. 1967: Suppl 108:3+.

37. Geissler, W. B. Arthroscopically assisted reduction of intra-articular fractures of the distal radius. Hand Clin. 1995, 11: 19-29. 
38. Geissler, W. B. Arthroscopic management of scapholunate instability. J Wrist Surg. 2013, 2: 129-135.

39. Geissler, W. B., Freeland, A. E. Arthroscopic management of intra-articular distal radius fractures. Hand Clin. 1999, 15: 455-465, viii.

40. Geissler, W. B., Freeland, A. E., Savoie, F. H., McIntyre, L. W., Whipple, T. L. Intracarpal softtissue lesions associated with an intra-articular fracture of the distal end of the radius. J Bone Joint Surg Am. 1996, 78: 357-365.

41. Gouk, C. J. C., Bindra, R. R., Tarrant, D. J., Thomas, M. J. E. Volar locking plate fixation versus external fixation of distal radius fractures: A meta-analysis. J Hand Surg Eur. Vol. 2018, 43: 954-960.

42. Guofen, C., Doi, K., Hattori, Y., Kitajima, I. Arthroscopically assisted reduction and immobilization of intraarticular fracture of the distal end of the radius: Several options of reduction and immobilization. Tech Hand Up Extrem Surg. 2005, 9: 84-90.

43. Gupta, S., Halai, M., Al-Maiyah, M., Muller, S. Which measure should be used to assess the patient's functional outcome after distal radius fracture? Acta Orthop Belg. 2014, 80: 116-118.

44. Gwathmey, F. W., Jr., Brunton, L. M., Pensy, R. A., Chhabra, A. B. Volar plate osteosynthesis of distal radius fractures with concurrent prophylactic carpal tunnel release using a hybrid flexor carpi radialis approach. J Hand Surg Am. 2010, 35: 1082-8 e4.

45. Hagert, C. G. Distal radius fracture and the distal radioulnar joint - anatomical considerations. Handchir Mikrochir Plast Chir. 1994, 26: 22-26.

46. Hayes, A. J., Duffy, P. J., McQueen, M. M. Bridging and non-bridging external fixation in the treatment of unstable fractures of the distal radius: A retrospective study of 588 patients. Acta Orthop. 2008, 79: 540-547.

47. Haugstvedt, J. R., Langer, M. F., Berger, R. A. Distal radioulnar joint: Functional anatomy, including pathomechanics. J Hand Surg Eur. Vol. 2017, 42: 338-345.

48. Ilyas, A. M., Jupiter, J. B. Distal radius fractures - classification of treatment and indications for surgery. Orthop Clin North Am. 2007, 38: 167-173, v.

49. Jakim, I., Pieterse, H. S., Sweet, M. B. External fixation for intra-articular fractures of the distal radius. J Bone Joint Surg Br. 1991, 73: 302-306.

50. Jellad, A., Salah, S., Ben Salah Frih, Z. Complex regional pain syndrome type i: Incidence and risk factors in patients with fracture of the distal radius. Arch Phys Med Rehabil. 2014, 95: 487-92.

51. Joseph, S. J., Harvey, J. N. The dorsal horizon view: Detecting screw protrusion at the distal radius. J Hand Surg Am. 2011, 36: 1691-1693.

52. Kaempffe, F. A., Wheeler, D. R., Peimer, C. A., Hvisdak, K. S., Ceravolo, J., Senall, J. Severe fractures of the distal radius: Effect of amount and duration of external fixator distraction on outcome. J Hand Surg Am. 1993, 18: 33-41.

53. Kamano, M., Koshimune, M., Kazuki, K., Honda, Y. Palmar plating for ao/asif c3.2 fractures of the distal radius with arthroscopically assisted reduction. Hand Surg. 2005, 10: 71-76.

54. Kapoor, H., Agarwal, A., Dhaon, B. K. Displaced intra-articular fractures of distal radius: A comparative evaluation of results following closed reduction, external fixation and open reduction with internal fixation. Injury. 2000, 31: 75-79.

55. Kasapinova, K., Kamiloski, V. Influence of associated lesions of the intrinsic ligaments on distal radius fractures outcome. Arch Orthop Trauma Surg. 2015, 135: 831-838.

56. Kastenberger, T., Kaiser, P., Schmidle, G., Schwendinger, P., Gabl, M., Arora, R. Arthroscopic assisted treatment of distal radius fractures and concomitant injuries. Arch Orthop Trauma Surg. 2020.

57. Khanchandani, P., Badia, A. Functional outcome of arthroscopic assisted fixation of distal radius fractures. Indian J Orthop. 2013, 47: 288-294. 
58. Kim, J. K., Park, M. G, Shin, S. J. What is the minimum clinically important difference in grip strength? Clin Orthop Relat Res. 2014, 472: 2536-2541.

59. Knirk, J. L., Jupiter, J. B. Intra-articular fractures of the distal end of the radius in young adults. J Bone Joint Surg Am. 1986, 68: 647-659.

60. Koo, O. T., Tan, D. M., Chong, A. K. Distal radius fractures: An epidemiological review. Orthop Surg. 2013, 5: 209-213.

61. Kreder, H. J., Hanel, D. P., Agel, J. et al. Indirect reduction and percutaneous fixation versus open reduction and internal fixation for displaced intra-articular fractures of the distal radius: A randomised, controlled trial. J Bone Joint Surg Br. 2005, 87: 829-836.

62. Kuner, E. H., Mellios, K., Berwarth, H. [treatment of complicated fracture of the distal radius with external fixator. Follow-up-complications-outcomes]. Unfallchirurg. 2002, 105: 199-207.

63. Lattmann, T., Dietrich, M., Meier, C., Kilgus, M., Platz, A. Comparison of 2 surgical approaches for volar locking plate osteosynthesis of the distal radius. J Hand Surg Am. 2008, 33: 1135-1143.

64. Leclercq, C., Mathoulin, C. Members of E. Complications of wrist arthroscopy: A multicenter study based on 10,107 arthroscopies. J Wrist Surg. 2016, 5: 320-326.

65. Levy, H. J., Glickel, S. Z. Arthroscopic assisted internal fixation of volar intraarticular wrist fractures. Arthroscopy. 1993, 9: 122-124.

66. Lindau, T. Arthroscopic evaluation of associated soft tissue injuries in distal radius fractures. Hand Clin. 2017, 33: 651-658.

67. Lindau, T., Adlercreutz, C., Aspenberg, P. Peripheral tears of the triangular fibrocartilage complex cause distal radioulnar joint instability after distal radial fractures. J Hand Surg Am. 2000, 25 : 464-468.

68. Lutsky, K., Boyer, M. I., Steffen, J. A., Goldfarb, C. A. Arthroscopic assessment of intra-articular distal radius fractures after open reduction and internal fixation from a volar approach. J Hand Surg Am. 2008, 33: 476-484.

69. Lutsky, K. F., Beredjiklian, P. K., Hioe, S., Bilello, J., Kim, N., Matzon, J. L. Incidence of hardware removal following volar plate fixation of distal radius fracture. J Hand Surg Am. 2015, 40: 2410-2415.

70. Lutz, M., Arora, R., Krappinger, D., Wambacher, M., Rieger, M., Pechlaner, S. Arthritis predicting factors in distal intraarticular radius fractures. Arch Orthop Trauma Surg. 2011, 131: 1121-1126.

71. Ma, C., Deng, Q., Pu, H. et al. External fixation is more suitable for intra-articular fractures of the distal radius in elderly patients. Bone Res. 2016, 4: 16017.

72. MacDermid, J. C., Roth, J. H., Richards, R. S. Pain and disability reported in the year following a distal radius fracture: A cohort study. BMC Musculoskelet Disord. 2003, 4: 24.

73. MacIntyre, N. J., Dewan, N. Epidemiology of distal radius fractures and factors predicting risk and prognosis. $J$ Hand Ther. 2016, 29: 136-145.

74. Mandziak, D. G., Watts, A. C., Bain, G. I. Ligament contribution to patterns of articular fractures of the distal radius. J Hand Surg Am. 2011, 36: 1621-1625.

75. Margaliot, Z., Haase, S. C., Kotsis, S. V., Kim, H. M., Chung, K. C. A meta-analysis of outcomes of external fixation versus plate osteosynthesis for unstable distal radius fractures. J Hand Surg Am. 2005, 30: 1185-1199.

76. McKay, S. D., MacDermid, J. C., Roth, J. H., Richards, R. S. Assessment of complications of distal radius fractures and development of a complication checklist. J Hand Surg Am. 2001, 26: 916-922.

77. McQueen, M. M., Michie, M., Court-Brown, C. M. Hand and wrist function after external fixation of unstable distal radial fractures. Clin Orthop Relat Res. 1992: 200-204.

78. Mehrzad, R., Kim, D. C. Complication rate comparing variable angle distal locking plate to fixed angle plate fixation of distal radius fractures. Ann Plast Surg. 2016, 77: 623-625. 
79. Mehta, J. A., Bain, G. I., Heptinstall, R. J. Anatomical reduction of intra-articular fractures of the distal radius. An arthroscopically-assisted approach. J Bone Joint Surg Br. 2000, 82: 79-86.

80. Moritomo, $\mathrm{H}$. The function of the distal interosseous membrane and its relevance to the stability of the distal radioulnar joint: An anatomical and biomechanical review. Handchir Mikrochir Plast Chir. 2015, 47: 277-280.

81. Mrkonjic, A., Lindau, T., Geijer, M., Tagil, M. Arthroscopically diagnosed scapholunate ligament injuries associated with distal radial fractures: A 13- to 15-year follow-up. J Hand Surg Am. 2015, 40: 1077-1082.

82. Nakamura, T., Yabe, Y. Histological anatomy of the triangular fibrocartilage complex of the human wrist. Ann Anat. 2000, 182: 567-572.

83. Nakamura, T., Yabe, Y., Horiuchi, Y. Functional anatomy of the triangular fibrocartilage complex. J Hand Surg Br. 1996, 21: 581-586.

84. Nishiwaki, M., Welsh, M., Gammon, B., Ferreira, L. M., Johnson, J. A., King, G. J. Volar subluxation of the ulnar head in dorsal translation deformities of distal radius fractures: An in vitro biomechanical study. J Orthop Trauma. 2015, 29: 295-300.

85. Odumala, O., Ayekoloye, C., Packer, G. Prophylactic carpal tunnel decompression during buttress plating of the distal radius - is it justified? Injury. 2001, 32: 577-579.

86. Ogawa, T., Tanaka, T., Yanai, T., Kumagai, H., Ochiai, N. Analysis of soft tissue injuries associated with distal radius fractures. BMC Sports Sci Med Rehabil. 2013, 5: 19.

87. Ono, H., Furuta, K., Fujitani, R., Katayama, T., Akahane, M. Distal radius fracture arthroscopic intraarticular displacement measurement after open reduction and internal fixation from a volar approach. J Orthop Sci. 2010, 15: 502-508.

88. Ono, H., Katayama, T., Furuta, K., Suzuki, D., Fujitani, R., Akahane, M. Distal radial fracture arthroscopic intraarticular gap and step-off measurement after open reduction and internal fixation with a volar locked plate. J Orthop Sci. 2012, 17: 443-449.

89. Orbay, J. L., Fernandez, D. L. Volar fixation for dorsally displaced fractures of the distal radius: A preliminary report. J Hand Surg Am. 2002, 27: 205-215.

90. Orbay, J. L., Fernandez, D. L. Volar fixed-angle plate fixation for unstable distal radius fractures in the elderly patient. J Hand Surg Am. 2004, 29: 96-102.

91. Osada, D., Viegas, S. F., Shah, M. A., Morris, R. P., Patterson, R. M. Comparison of different distal radius dorsal and volar fracture fixation plates: A biomechanical study. J Hand Surg Am. 2003, 28: 94-104.

92. Palmer, A. K., Werner, F. W. Biomechanics of the distal radioulnar joint. Clin Orthop Relat Res. 1984: 26-35.

93. Patterson, R. W., Li, Z., Smith, B. P., Smith, T. L., Koman, L. A. Complex regional pain syndrome of the upper extremity. J Hand Surg Am. 2011, 36: 1553-1562.

94. Peicha, G., Seibert, F., Fellinger, M., Grechenig, W. Midterm results of arthroscopic treatment of scapholunate ligament lesions associated with intra-articular distal radius fractures. Knee Surg Sports Traumatol Arthrosc. 1999, 7: 327-333.

95. Rhee, P. C., Dennison, D. G., Kakar, S. Avoiding and treating perioperative complications of distal radius fractures. Hand Clin. 2012, 28: 185-198.

96. Richard, M. J., Wartinbee, D. A., Riboh, J., Miller, M., Leversedge, F. J., Ruch, D. S. Analysis of the complications of palmar plating versus external fixation for fractures of the distal radius. J Hand Surg Am. 2011, 36: 1614-1620.

97. Richards, R. S., Bennett, J. D., Roth, J. H., Milne, K. Jr. Arthroscopic diagnosis of intra-articular soft tissue injuries associated with distal radial fractures. J Hand Surg Am. 1997, 22: 772-776.

98. Rikli, D. A., Kupfer, K., Bodoky, A. Long-term results of the external fixation of distal radius fractures. J Trauma. 1998, 44: 970-976. 
99. Roh, Y. H., Lee, B. K., Baek, J. R., Noh, J. H., Gong, H. S., Baek, G. H. A randomized comparison of volar plate and external fixation for intra-articular distal radius fractures. J Hand Surg Am. 2015, 40: 34-41.

100. Roulet, S., Ardouin, L., Bellemere, P., Leroy, M. Scapholunate, lunotriquetral and tfcc ligament injuries associated with intraarticular distal radius fractures: Arthroscopic assessment and correlation with fracture types. Hand Surg Rehabil. 2020, 39: 102-106.

101. Rozental, T. D., Bozentka, D. J., Katz, M. A., Steinberg, D. R., Beredjiklian, P. K. Evaluation of the sigmoid notch with computed tomography following intra-articular distal radius fracture. J Hand Surg Am. 2001, 26: 244-251.

102. Ruch, D. S., Yang, C. C., Smith, B. P. Results of acute arthroscopically repaired triangular fibrocartilage complex injuries associated with intra-articular distal radius fractures. Arthroscopy. 2003, 19: 511-516.

103. Ruch, D. S., Papadonikolakis, A. Volar versus dorsal plating in the management of intra-articular distal radius fractures. J Hand Surg Am. 2006, 31: 9-16.

104. Ruch, D. S., Vallee, J., Poehling, G. G., Smith, B. P., Kuzma, G. R. Arthroscopic reduction versus fluoroscopic reduction in the management of intra-articular distal radius fractures. Arthroscopy. 2004, 20: 225-230.

105. Saito, T., Nakamura, T., Nagura, T., Nishiwaki, M., Sato, K., Toyama, Y. The effects of dorsally angulated distal radius fractures on distal radioulnar joint stability: A biomechanical study. $J$ Hand Surg Eur Vol. 2013, 38: 739-745.

106. Sander, A. L., Leiblein, M., Sommer, K., Marzi, I., Schneidmuller, D., Frank, J. Epidemiology and treatment of distal radius fractures: Current concept based on fracture severity and not on age. Eur J Trauma Emerg Surg. 2018.

107. Scheer, J. H., Adolfsson, L. E. Patterns of triangular fibrocartilage complex (tfcc) injury associated with severely dorsally displaced extra-articular distal radius fractures. Injury. 2012, 43: 926-932.

108. Schuind, F., Donkerwolcke, M., Rasquin, C., Burny, F. External fixation of fractures of the distal radius: A study of 225 cases. J Hand Surg Am. 1989, 14: 404-407.

109. Schuind, F. A., Cantraine, F. R., Fabeck, L., Burny, F. Radiocarpal articular pressures during the reduction of distal radius fractures. J Orthop Trauma. 1997, 11: 295-299.

110. Seigerman, D., Lutsky, K., Fletcher, D. et al. Complications in the management of distal radius fractures: How do we avoid them? Curr Rev Musculoskelet Med. 2019, 12: 204-212.

111. Seitz, W. H., Jr., Froimson, A. I., Leb. R., Shapiro, J. D. Augmented external fixation of unstable distal radius fractures. J Hand Surg Am. 1991, 16: 1010-1016.

112. Selles, C. A., Reerds, S. T. H., Roukema, G., van der Vlies, K. H., Cleffken, B. I., Schep, N. W. L. Relationship between plate removal and soong grading following surgery for fractured distal radius. J Hand Surg Eur. Vol. 2018, 43: 137-141.

113. Shukla, R., Jain, R. K., Sharma, N. K., Kumar, R. External fixation versus volar locking plate for displaced intra-articular distal radius fractures: A prospective randomized comparative study of the functional outcomes. J Orthop Traumatol. 2014, 15: 265-270.

114. Siripakarn, Y., Suntarapa, T., Chernchujit, B. Multipurpose external fixation for unstable comminuted intraarticular fracture of distal radius. J Med Assoc Thai. 2013, 96: 446-455.

115. Soong, M., van Leerdam, R., Guitton, T. G., Got, C., Katarincic, J., Ring, D. Fracture of the distal radius: Risk factors for complications after locked volar plate fixation. J Hand Surg Am. 2011, 36: 3-9.

116. Swart, E., Tang, P. The effect of ligament injuries on outcomes of operatively treated distal radius fractures. Am J Orthop (Belle Mead NJ). 2017, 46: E41-E6.

117. Trumble, T. E., Schmitt, S. R., Vedder, N. B. Factors affecting functional outcome of displaced intra-articular distal radius. J Hand Surg Am. 1994, 19: 325-340. 
118. Varitimidis, S. E., Basdekis, G. K., Dailiana, Z. H., Hantes, M. E., Bargiotas, K., Malizos, K. Treatment of intra-articular fractures of the distal radius: Fluoroscopic or arthroscopic reduction? J Bone Joint Surg Br. 2008, 90: 778-785.

119. Vidal, J. A. J., Connes, H. et al. A biomechanical study and clinical application of the use of hoffman's external fixator. Baltimore, Williams \& Wilkins. 1979.

120. Wadsten, M. A., Buttazzoni, G. G., Sjoden, G. O., Kadum, B., Sayed-Noor, A. S. Influence of cortical comminution and intra-articular involvement in distal radius fractures on clinical outcome: A prospective multicenter study. J Wrist Surg. 2017, 6: 285-293.

121. Walenkamp, M. M., Bentohami, A., Beerekamp, M. S. et al. Functional outcome in patients with unstable distal radius fractures, volar locking plate versus external fixation: A meta-analysis. Strategies Trauma Limb Reconstr. 2013, 8: 67-75.

122. Walenkamp, M. M., de Muinck Keizer, R. J., Goslings, J. C., Vos, L. M., Rosenwasser, M. P., Schep, N. W. The minimum clinically important difference of the patient-rated wrist evaluation score for patients with distal radius fractures. Clin Orthop Relat Res. 2015, 473: 3235-3241.

123. Waljee, J. F., Ladd, A., MacDermid, J. C., Rozental, T. D., Wolfe, S. W., Distal Radius Outcomes C. A unified approach to outcomes assessment for distal radius fractures. J Hand Surg Am. 2016, 41: 565-573.

124. Weber, S. C., Szabo, R. M. Severely comminuted distal radial fracture as an unsolved problem: Complications associated with external fixation and pins and plaster techniques. J Hand Surg Am. 1986, 11: 157-165.

125. Whipple, T. L. The role of arthroscopy in the treatment of intra-articular wrist fractures. Hand Clin. 1995, 11: 13-18.

126. Whipple, T. L., Marotta, J. J., Powell, J. H., 3rd. Techniques of wrist arthroscopy. Arthroscopy. 1986, 2: 244-252.

127. Wilcke, M. K., Abbaszadegan, H., Adolphson, P. Y. Wrist function recovers more rapidly after volar locked plating than after external fixation but the outcomes are similar after 1 year. Acta Orthop. 2011, 82: 76-81.

128. Williksen, J. H., Frihagen, F., Hellund, J. C., Kvernmo, H. D., Husby, T. Volar locking plates versus external fixation and adjuvant pin fixation in unstable distal radius fractures: A randomized, controlled study. J Hand Surg Am. 2013, 38: 1469-1476.

129. Wolfe, S. W. Distal radius fractures, 7th edn. Philadelphia, Elsevier, 2017.

130. Wolfe, S. W., Swigart, C. R., Grauer, J., Slade, J. F., 3rd, Panjabi, M. M. Augmented external fixation of distal radius fractures: A biomechanical analysis. J Hand Surg Am. 1998, 23: 127-134.

131. Wright, T. W., Horodyski, M., Smith, D. W. Functional outcome of unstable distal radius fractures: Orif with a volar fixed-angle tine plate versus external fixation. J Hand Surg Am. 2005, 30: 289-299.

132. Xie, X., Qin, H., Shen, L., Zhang, C. Comparison of internal and external fixation of distal radius fractures. Acta Orthop. 2013, 84: 286-291.

133. Zenke, Y., Sakai, A., Oshige, T., Moritani, S., Nakamura, T. The effect of an associated ulnar styloid fracture on the outcome after fixation of a fracture of the distal radius. J Bone Joint Surg Br. 2009, 91: 102-107. 


\section{Pateicības}

Pirmām kārtām es pateicos savai ǵimenei - sieviņai Daigai, meitām Laurai un Annai, dēlam Emīlam ar ğimeni -, kura pārcieta visus šos piecus un vairāk gadus, kad biju spiests nodarboties ar promocijas darba materiāla vākšanu, apkopošanu, kā arī rakstǐšanu. Esmu neizsakāmi priecīgs un pateicīgs, ka viṇi saprata ğimenei atņemtā laika izlietošanas iemeslus un brīžos, kad man viss likās apnicis, spēja mani iedvesmot un motivēt turpināt iesākto. Es pateicos maniem vecākiem Intai un Bruno un esmu laimīgs, ka viṇi, kuri ar̄̄ ir medicīnas darbinieki, spējuši mani iedvesmot kḷūt par mediķi un šobrīd joprojām ir kopāa ar mani šeit un tagad, dalot šī notikuma priekus kopīgi.

Nākamā pateicība ir maniem kolẹgiem un manai darbavietai Latvijas plastiskās, rekonstruktīvās un mikroḳirurg̣ijas centram, bez kura koleg̣iālā un finansiālā atbalsta šis projekts paliktu tikai idejas līmen̄̄. Es esmu patiesi gandarīts, ka strādāju komandā, kurā mājo attīstības, akadēmiskuma un inovāciju gars. Uzsākot plaukstas artroskopiskās operācijas Latvijāâ, mēs būtībā investējām nezināmajā, taču šobrīd varu ar lepnumu teikt, ka esam sasnieguši līmeni, ar kuru neatpaliekam no vadošajām Eiropas rokas ķirurğijas klīnikām.

Esmu laimīgs, jo Latvijas vārdu varu iznest pasaulē ar savu akadēmisko pieredzi, zināšanām un darba rezultātiem, kuri ir novērtēti Eiropas un arī pasaules rokas ķirurgu sabiedrībā.

Es pateicos arī RSU mācībspēkiem, kuri izglītoja mani doktorantūras studiju laikā, un ar patiesu cieņu pieminu docētājus un profesorus, kuri no manis izveidoja ārstu studiju laikā (tas bija sen, jo mācību iestādi, kuru es beidzu, sauca Latvijas Medicīnas akadēmija).

Visbeidzot es pateicos visiem cilvēkiem, kuri man tehniski, morāli un ar padomu palīdzēja gan citējamo rakstu tapšanā, gan promocijas darba noformēšanā, asistējot operācijās un palīdzot apkopot rezultātus. Īpaša pateicība Latvijas labākajai rokas ergoterapeitei Diānai Bringinai, bez kuras nenovērtējamām pūlēm un iecietības daḷa manu izoperēto pacientu nebūtu sasnieguši vēlamos rezultātus. 
Pielikumi 


\section{PRWE un MASS07 aptauja}

\section{PRWE aptauja.}

Vārds, Uzvārds Datums

Uzdotie jautājumi un Jūsu sniegtās atbildes laus mums izprast, cik lielu apgrūtinājumu un diskomfortu Jūs esat izjutuši, operētajā rokā, pagājušās nedēḷas laikā. Jums ir jāapraksta vidējos plaukstas simptomus pagājušās nedēlas laikā skalā no 0 līdz 10. Lūdzu sniedziet atbildes uz visiem jautājumiem. Ja jūs neesat veikuši kādas no minētajām darbībām, tad lūdzu IZVERTĒJIET iespējamo sāpju vai grūtību iespēju. Ja Jūs nekad neesat veikuši šādu darbību, Jūs drīkstat atstāt neatbildētu jautājumu.

1. SĀPES

Novērtējat vidējo sāpju apjomu pagājušās nedēḷs laikā, apvelkot skaitli no 0 līdz 10, kas Jūsuprāt vislabāk raksturo sāpes Jūsu operētajā plaukstā. Nulle ( 0 ) nozīmē, ka nekādu sāpju nav, bet desmit ( 10 ) nozīmē, ka Jums ir vislielākās sāpes, kādas vispār ir bijušas Jūsu dzīves laikā, vai arī Jūs nevarat veikt nekādas aktivitātes sāpju dēl.

Izvērtējat sāpes: ( parauga skala )

$$
\begin{array}{llllllllllll}
0 & 1 & 2 & 3 & 4 & 5 & 6 & 7 & 8 & 9 & 10
\end{array}
$$

Nav sāpju

Vislielākās sāpes mūžă

Miera stāvoklī

$\begin{array}{llllllllllll}0 & 1 & 2 & 3 & 4 & 5 & 6 & 7 & 8 & 9 & 10\end{array}$

Veicot darbību ar atkārtotām plaukstas kustībām

$\begin{array}{llllllllllll}0 & 1 & 2 & 3 & 4 & 5 & 6 & 7 & 8 & 9 & 10\end{array}$

Ceḷt smagu priekšmetu

Visspēcīgākās sāpes pagājušajā nedēẹā

$\begin{array}{lllllllllll}0 & 1 & 2 & 3 & 4 & 5 & 6 & 7 & 8 & 9 & 10\end{array}$

Cik bieži Jums sāp

$\begin{array}{lllllllllll}0 & 1 & 2 & 3 & 4 & 5 & 6 & 7 & 8 & 9 & 10\end{array}$

$\begin{array}{lllllllllll}0 & 1 & 2 & 3 & 4 & 5 & 6 & 7 & 8 & 9 & 10\end{array}$

Nekad

Visu laiku

\section{FUNKCIJAS}

A. Specifiskās aktivitātes

Izvērtējat grūtības pakāpi, kādu Jūs izjutāt, veicot tālāk minētās darbības, pēdējās nedēḷas laikā, atzīmējot skaitli skalā no 0 lĩdz 10. Nulle ( 0 ) nozīmē, ka Jums nav bijušas grūtības, veicot konkrēto darbību, bet desmit ( 10 ) nozīmē, ka Jūs pilnībā nespējat veikt konkrēto darbību.

Parauga skala

$$
\begin{array}{lllllllllll}
0 & 1 & 2 & 3 & 4 & 5 & 6 & 7 & 8 & 9 & 10
\end{array}
$$

$$
\text { Nav grūtību }
$$

Neiespējami veikt

Pagriezt durvju rokturi/slēdzeni ar operēto roku

$$
\begin{array}{lllllllllll}
0 & 1 & 2 & 3 & 4 & 5 & 6 & 7 & 8 & 9 & 10 \\
0 & 1 & 2 & 3 & 4 & 5 & 6 & 7 & 8 & 9 & 10 \\
0 & 1 & 2 & 3 & 4 & 5 & 6 & 7 & 8 & 9 & 10 \\
0 & 1 & 2 & 3 & 4 & 5 & 6 & 7 & 8 & 9 & 10 \\
0 & 1 & 2 & 3 & 4 & 5 & 6 & 7 & 8 & 9 & 10 \\
0 & 1 & 2 & 3 & 4 & 5 & 6 & 7 & 8 & 9 & 10
\end{array}
$$$$
\text { Griezt gaḷu, turot nazi operētajā rokā }
$$$$
\text { Aizpogāt pogas kreklam/blūzei }
$$$$
\text { Izmantot operēto roku, atspiežoties mo krēsla }
$$

Lietot tualetes papīru ar operēto plaukstu

B. Parastās aktivitātes

Lūdzu izvērtējiet tālāk minēto ikdienas aktivitāšu grūtības pakāpi pēdējās nedēḷ laikā, atzīmējot skaitli skalā no 0 līdz 10. "Parastās aktivitātes " nozīmē lietas, ko Jūs darījāt pirms plaukstas traumas. Nulle ( 0 ) nozīmē, ka Jums nav bijušas grūtības, veicot konkrēto darbību, bet desmit ( 10 ) nozīmē, ka Jūs pilnībā nespējat veikt konkrēto darbību.

Personiskā aprūpe ( gēerbšanās/ mazgāšanās ) $\begin{array}{lllllllllll}0 & 1 & 2 & 3 & 4 & 5 & 6 & 7 & 8 & 9 & 10\end{array}$ 
Mājas darbi ( tīrī̌sana/ kārtošana )
Strādāšana ( darbā vai ikdienas pienākumos )

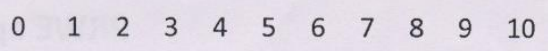

\section{MASS07 aptauja.}

Lūdzu izvērtējiet tālāk minēto aktivitāšu grūtības pakāpi pēdējās nedēlas laikā, lietojot operēto plaukstu, atzīmējot skaitli skalā no 0 līdz 10. Nulle ( 0 ) nozīmē, ka Jums nav bijušas grūtības, veicot konkrēto darbību, bet desmit ( 10 ) nozīmē, ka Jūs pilnībā nespējat veikt konkrēto darbību.

$\begin{array}{llllllllllll}\text { Rakstīt uz datora klaviatūras } & 0 & 1 & 2 & 3 & 4 & 5 & 6 & 7 & 8 & 9 & 10 \\ \text { Lietot datora peli } & 0 & 1 & 2 & 3 & 4 & 5 & 6 & 7 & 8 & 9 & 10 \\ \text { Lietot mobilo telefonu } & 0 & 1 & 2 & 3 & 4 & 5 & 6 & 7 & 8 & 9 & 10 \\ \text { Fotogrāfēt ar fotokameru } & 0 & 1 & 2 & 3 & 4 & 5 & 6 & 7 & 8 & 9 & 10 \\ \text { Izvilkt no kabatas kādu priekšmetu (atslēgas u.c.) } & 0 & 1 & 2 & 3 & 4 & 5 & 6 & 7 & 8 & 9 & 10 \\ \text { Parakstīties } & 0 & 1 & 2 & 3 & 4 & 5 & 6 & 7 & 8 & 9 & 10 \\ \text { Izṇemt banknoti no maka } & 0 & 1 & 2 & 3 & 4 & 5 & 6 & 7 & 8 & 9 & 10 \\ \text { lespraust kontaktdakšu elektrības rozetē } & 0 & 1 & 2 & 3 & 4 & 5 & 6 & 7 & 8 & 9 & 10 \\ \text { Mazgāt/salocit velu } & 0 & 1 & 2 & 3 & 4 & 5 & 6 & 7 & 8 & 9 & 10 \\ \text { Rakstīt uz skärienjūtīga ekrāna } & 0 & 1 & 2 & 3 & 4 & 5 & 6 & 7 & 8 & 9 & 10\end{array}$


Modificēta Gartland \& Werley skala

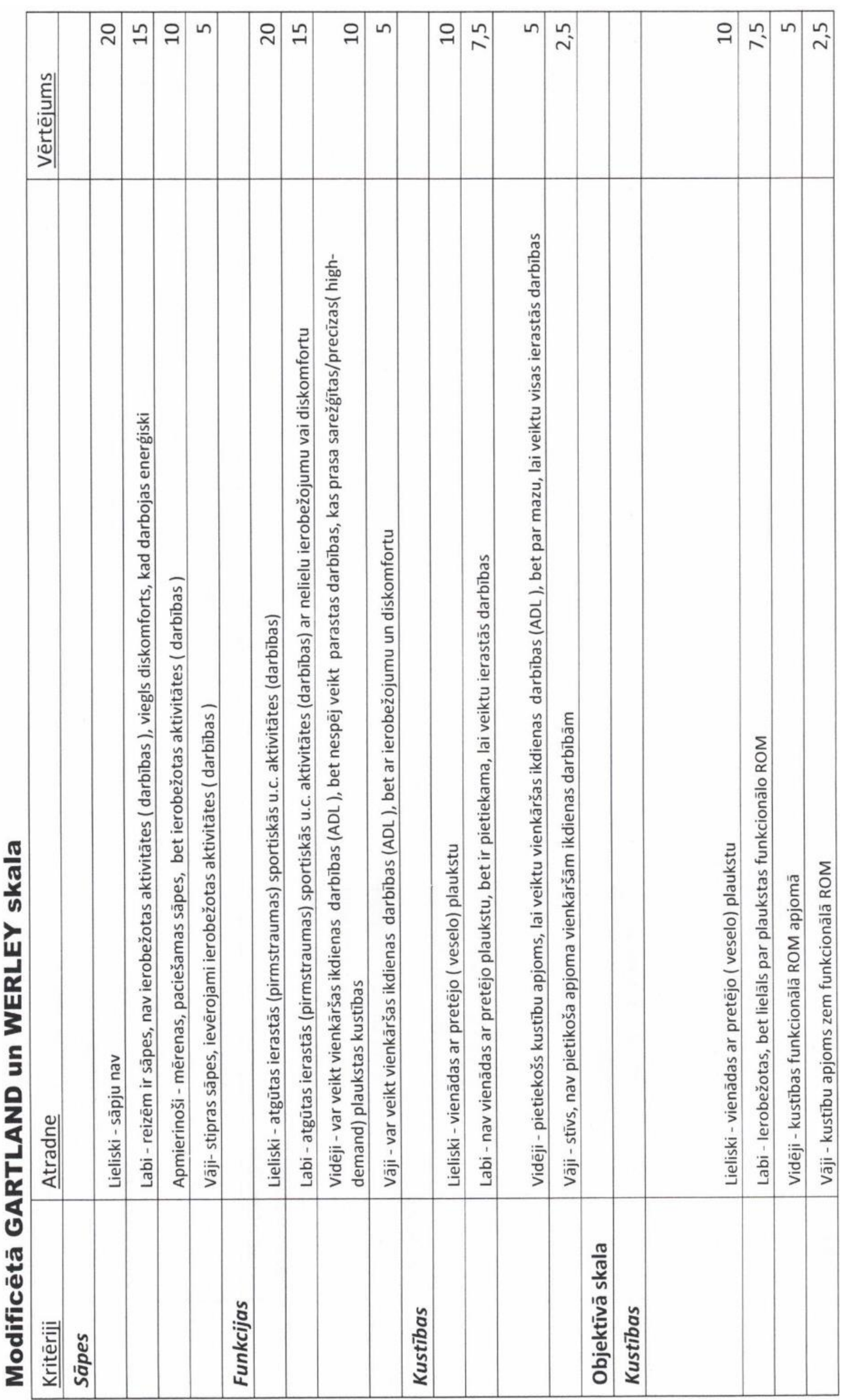


2. pielikuma turpinājums

Modificēta Gartland \& Werley skala

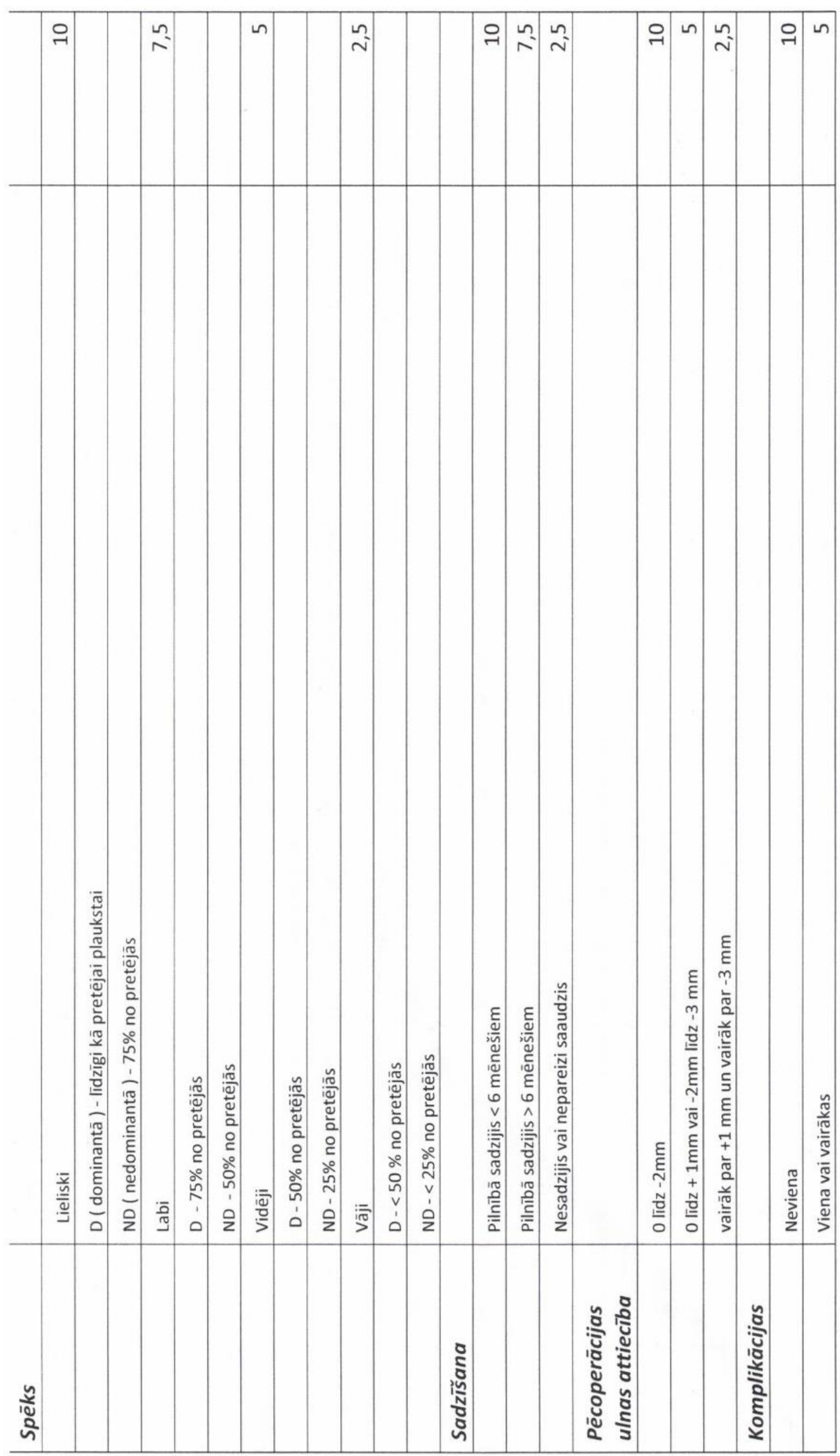




\section{Piekrišana pētījumam}

Cienītā kundze!

Godātais kungs!

Mēs uzaicinām Jūs / Jūsu bērnu vai aizbildināmo piedalīties pêtījumā “Ārstēšanas rezultātu izvērtējums pēc spiek̦a kaula distālo artikulāro lūzumu osteosintēzes ar artroskopiski kontrolētām iekšējās un ārējās fiksācijas metodēm”, ko veic Mikroḳirurğijas centra ārsts Uldis Krustiņš. Vēlamies Jūs iepazīstināt ar pētījuma mērḳi, norisi un saturu. Pirms šī dokumenta parakstīšanas rūpīgi izlasiet visu informāciju! Pirms dokumenta parakstīšanas Jums ir tiesības uzdot jautājumus par pētījumu un saņemt uz tiem atbildes.

\section{Pētījuma mērḳis}

Salīdzināt divas artroskopiski kontrolētas spieķa kaula distālās metaepifizzes multifragmentāru intraartikulāru lūzumu osteosintēzes metodes pēc to agrīnajiem un vēlīnajiem klīniskajiem, radiologiskajiem un funkcionālajiem rezultātiem.

\section{Pētījuma norise}

Jums / Jūsu bērnam jau ir veikta nepieciešamā operācija. Pēc veiktās operācijas tiek piedāvātas 3-4 vizītes pie ārstējošāā ārsta gada laikā, kurās tiks veikti funkcionālie mērījumi un dzīves kvalitāti izvērtējoša anketēšana (standarta pēcoperācijas novērtēšana). Katrā vizītē pacientam tiek veikts:

1) vizuālais novērtējums, kustību apjoma mērījumi, izmantojot digitālo goniometru, plaukstas un pirkstu tvēriena spēka mērījumi (Grip / Pinch strenght) ar Jamar dinamometru, iegūto rezultātu fiksēšana un izvērtěšana pēc Gartland un Werley skalas;

2) anketēšana ar PRWE (Patient-Rated Wrist Evaluation), VAS (Visual Analoge Scale) un MASS07 tabulām.

\section{Ieguvumi}

Tiks izstrādātas vienas vai otras metodes lietošanas indikācijas noteikta lūzuma gadījumā noteiktai pacientu grupai, prognozējot iespējamo ārstēšanas rezultātu un mazinot komplikāciju risku.

\section{Iespējamie riski}

Nav tiešu risku no kustību apjoma mērījumu veikšanas un anketas aizpildīšanas.

Ir potenciāli riski, kas saistīti ar iegūto traumu un veiktās ķirurğiskās ārstēšanas lietošanu brūču dzīšanas traucējumi, infekcijas risks, sāpes un kustību ierobežojumi pēc imobilizācijas un kustîbu iestrādes, kas ir obligāta ārstēšanas procesa (bet ne pētījuma) sastāvdaḷa.

\section{Konfidencialitāte}

Pacientu anketas tiek šifrētas burtu un ciparu kombinācijā.

Vārds, uzvārds un personas kods netiek lietoti. 
3. pielikuma turpinājums

\section{Brīvprātīga piedalīšanās}

Piedalīšanās šajā pētījumā ir brīvprātīga. Jums ir tiesības atteikties piedalīities pētījumā vai pārtraukt līdzdalību pētījumā jebkurā laikā. Jūsu atteikšanās piedalīties pētījumā vai līdzdalības pārtraukšana neradīs nekādu nevēlamu ietekmi uz Jums sniegtās veselības aprūpes kvalitāti.

Ja jums ir jebkādi jautājumi par šo pētījumu, lūdzu, sazinieties ar Dr. Uldi Krustiṇu Mikroķirurğijas centrā, tel. 67042641.

Šis dokuments ir divos eksemplāros, no kuriem viens atrodas pie pētījuma veicēja, bet otrs - pie pētāmās personas.

Es ar savu parakstu apliecinu, ka esmu iepazinies / usies ar šĩ dokumenta saturu. Es saprotu, ka mana / mana bērna līdzdalība šajā pētîjumā ir brīvprātīga un atteikšanās piedalīties neizraisīs nekādas nelabvēlīgas sekas. Man ir tiesības pārtraukt līdzdalību pêtījumā jebkurā laikā.
Vārds, uzvārds
Datums
Paraksts

Pētnieks:
Uldis Krustiňš Datums $\quad$ Paraksts


4. pielikums

\section{Pētijuma pēcoperācijas protokoli}

Pacientiem ar spieķa kaula distālu artikulāru lūzumu, kas operēti ar volāro kompresijas plāksni:

1. 2. pēcoperācijas dienā - aktīvās aspirācijas drenas evakuācija un pārsēja maiņa, izrakstīšana no stacionāra

2. Pārsēju maiṇa reizi 3-4 dienās

3. Šuvju noṇemšana 12-14 dienas pēc operācijas

4. Imobilizācija līdz šuvju noṇemšanai

5. Sākot ar 2. pēcoperācijas dienu - pleca, elkoṇa un pirkstu kustību uzsākšana pēc vienota protokola

6. Sākot ar 3. pēcoperācijas nedẹḷ - plaukstas locìtavas aktīvo un pasīvo kustību iestrāde MC rehabilitologa uzraudzībā

7. RTG kontrole 4 nedēḷas pēc operācijas

8. Kontroles pie ārstējošā ārsta 1, 3, 6 un 12 mēnešus pēc operācijas. Pēc tam - reizi gadā

Pacientiem ar spieķa kaula distālu artikulāru lūzumu, kas operēti ar stieplēm un ĀFA:

1. 2. pēcoperācijas dienā - pārsēja maiņa un izrakstīšana no stacionāra

2. Pārsēju maiṇa reizi 3-4 dienās

3. Ar 2. pēcoperācijas dienu - pleca, elkoṇa un pirkstu kustību uzsākšana pēc vienota protokola

4. Šuvju noṇemšana $12-14$ dienas pēc operācijas

5. RTG kontrole 4 nedēlas pēc operācijas

6. ĀFA un stiepḷu demontāža 4-6 nedēḷas pēc operācijas

7. Plaukstas locītavas aktīvo un pasīvo kustību iestrāde MC rehabilitologa uzraudzībā pēc fiksatoru izṇemšanas

8. Kontroles pie ārstējošā ārsta 1, 3,6 un 12 mēnešus pēc operācijas. Pēc tam - reizi gadā

Katrā vizītē pacientam tiek veikts:

- vizuālais novērtējums;

- $\quad$ kustību apjoma mērījumi, izmantojot digitālo goniometru;

- plaukstas un pirkstu tvēriena spēka mērījumi (Grip / Pinch strenght) ar Jamar dinamometru, iegūto rezultātu fiksēšana un izvērtēšana pēc Gartland un Werley skalas;

- $\quad$ anketēšana ar PRWE (Patient-Rated Wrist Evaluation) un MASS07 tabulām 


\section{$\bar{E}$ tikas komitejas atzinums}

\section{fonds.ētika}

Darbojas saskaņā ar SHK LKP noteikumiem

Nr. 22-A/15
03.09.2015.
Rīgā

Rīgas Austrumu klīniskās universitātes slimnīcas atbalsta fonda Medicīnisko un biomedicīnisko pētījumu Ētikas komitejas

\section{ATZINUMS}

Pētijjuma nosaukums : Ārstēšanas rezultātu izvērtējums pēc spieķa kaula distālo artikulāro lūzumu osteosintēzes ar artroskopiski kontrolētām iekšējās un ārējās fiksācijas metodēm

Pētījuma pieteikuma iesniedzējs: Uldis Krustiņš

Pētījuma pieteikuma iesniedzēja darba vieta: $\mathrm{RSU}$, doktorantūra

SIA "Rīgas Austrumu klīniskās universitātes slimnīcas" atbalsta fonda Medicīnisko un biomedicīnisko pētījumu Ētikas komiteja(sēdes prot.10/15., 03.09.15.) ir izvērtējusi plānotā zinātniskā pētījuma nozīmi un mērķi, iesniedzēja sniegto paredzamā ieguvuma un riska novērtējumu un tā pamatotību. Balstoties uz iesniegto dokumentu izvērtējumu, komiteja nolēma izteikt:

- pozitīvu atzinumu

$\square$ negatīvu atzinumu, ar iespēju veikt izmaiņas un iesniegt pieteikumu atkārtoti

$\square$ negatīvu atzinumu

par pieteikuma atbilstību zinātnisko pētījumu ētikas prasībām.

Rīgas Austrumu klīniskās universitātes slimnīcas atbalsta fonda Medicīnisko un biomedicīnisko pētījumu

Ētikas komitejas priekšsēdētājs Roberts Stašinskis

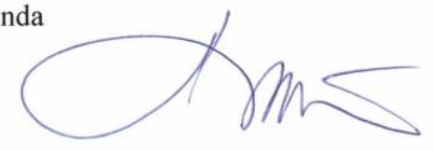




\section{RAKUS piekrišana akadēmiskā pētījuma veikšanai}

\section{aslimnica}

SIA Rīgas Austrumu klīniskã universitātes slimnīca Registrãcijas Nr.: 40003951628

Hipokrăta iela 2, Riga, LV-1038, Latvija

Tälr: 67042 400, fakss: 67042786

E-pasts: aslimnica@aslimnica.Iv,www.aslimnica.Iv

2016.gada 9.februārī

Nr. A1/1.1-07/16/
Pielikums Nr. 3

APSTIPRINĀTS

ar SIA „Rīgas Austrumu klīniskā universitātes

slimnīca" valdes

2014. gada 17. aprīḷa lēmumu Nr. V1/01-01/14/192
Rīgā

Dr. Uldim Krustiņam

Stacionārs „Gaiḷezers"

Rokas un plastiskās k̦irurğijas nodaḷa

PIEKRIŠANA AKADĒMISKĀ PĒTĪJUMA VEIKŠANAI

Esmu informēta par akadēmiskā pētījuma , „Arstēšanas rezultātu izvērtējums pēc spieķa kaula distālo artikulāro lüzumu osteosintēzes ar artroskopiski kontrolētām iekšējāas un ārējās fiksācijas metodēm”, atbildīgā pētnieka Dr.Ulda Krustiṇa vadībā, veikšanu SIA „Rīgas Austrumu klīniskā universitātes slimnīca“.

Piekrītu minētā pētijuma veikšanai Sabiedrības stacionārā „Gaiḷezers“.

Pētijums uzsākams pēc Ētikas komitejas atzinuma saṇemšanas un atzinuma kopijas iesniegšanas Zinātnes dạ̦ā.

Valdes priekšsēdētāja

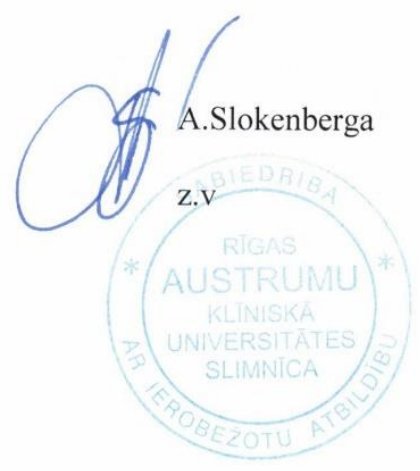

Sagatavoja:

Ita Sprukule

67014578

Ita.sprukule@aslimnica.Iv 


\title{
Konfidencialitātes apliecinājums
}

2. pielikums

APSTIPRINĀTS

ar SIA ,Rīgas Austrumu klīniskā universitātes slimnīca” valdes

2014. gada 17. aprīḷa lēmumu Nr. V1/01-01/14/192

\author{
KONFIDENCIALITĀTES APLIECINĀJUMS
}

Saskaṇā ar LR Pacienta tiesību likuma 10. panta „Pacienta datu aizsardzība” septītajā un astotajā daḷā minētajiem nosacījumiem par medicīniskajos dokumentos fiksēto pacientu datu izmantošanu pētījumā, es, Uldis Krustiņš, personas kods 310570-10536, RSU doktorants, Studenta apliecības Nr. 15-024453, ievērošu konfidencialitāti darbā ar slimnieku slimības vēsturēm un slimniekiem. Tāpat saskaṇā ar LR Fizisko personu datu aizsardzības likuma 11.pantu "Sensitīvo personas datu apstrāde" iegūtos pacientu medicīniskos datus, kā arī jebkāda veida citu informāciju par pacientiem vai to slimības vēsturēm izmantošu tikai zinātniski pētnieciskajam darbam.

Saskan̄ā ar LR Fizisko personu datu aizsardzības likumu un LR Pacienta tiesību likumu neizpaudīšu nekāda veida informāciju trešajām personām ne mutiski, ne rakstiski, ne elektroniskā veidā. Konfidencialitātes nosacījumus ievērošu arī pēc zinātniski pētnieciskā darba izstrādes pabeigšanas.

Solījumu apliecinu ar savu parakstu.

Darba autors: Uldis Krustiņš

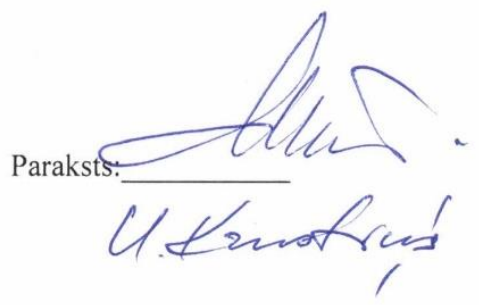

Datums: 27.01.2016. 
8. pielikums

\section{Pēcoperācijas novērojumu un rezultātu monitorēšanas pasākumu algoritms}

(lietojams spieḳkaula distālo galu lūzumu, kā arī plaukstas locītavas traumu vai ortopēdisko saslimšanu ārstēšanas subjektīvo un objektīvo rezultātu apkopošanai)

Objektīvo datu reǵistrācija

\section{Plaukstas locītavas aktīvo \\ kustību apjoms (fleksija,}

ekstensija, ulnārā un radiālā

deviācija, pronācija, supinācija)

Plaukstas satvēriena spēks Grip

(izmanto Jamar dinamometru)

Atslēgas tvēriena spēks Pinch

(izmanto pirkstu tvēriena

dinamometru)

\section{3 pirkstu tvēriena spēks 3P}

Pinch (izmanto pirkstu tvēriena dinamometru)

Radiologiskie parametri (radiālā inklinācija, volārā pārkare, spieķkaula augstums, elkoņkaula galviņas pozīcija - ulna + , neitrāla vai ulna - ). Šo rekomendēts veikt radiologam datorprogrammā.
Subjektīvo datu regiistrācija

\section{Patient-Related Wrist Evaluation} score (PRWE) (iespējamie rezultāti no 0 līdz 140, mazāks punktu skaits nozīmē labāku rezultātu)

Gartland un Werley skala (iespējamie rezultāti no 17,5 līdz 100, lielāks punktu skaits nozīmē labāku rezultātu)

MASS07 (Modern Activity Subjective Survey of 2007) (iespējamie rezultāti no 0 līdz 100, mazāks punktu skaits nozīmē labāku rezultātu)

Plaukstas locītavas ortopēdisko saslimšanu gadījumos datu reǵistrāciju un izvērtēšanu rekomendēts veikt arī pirms operācijas, lai varētu salīdzināt iegūtos parametrus pre- un postoperatīvi dinamikā.

Pēcoperācijas rezultātu izvērtēšanai dinamikā rekomendēts veikt datu pierakstu 1, 3, 6 un 12 mēnešus pēc operācijas, kā arī ilgtermiņā, ja tas paredzēts konkrēta pētījuma metodikā. 


\section{Algoritms artikulāro spieḳkaula distālā gala lūzumu ārstēšanas metožu izvēlei.}

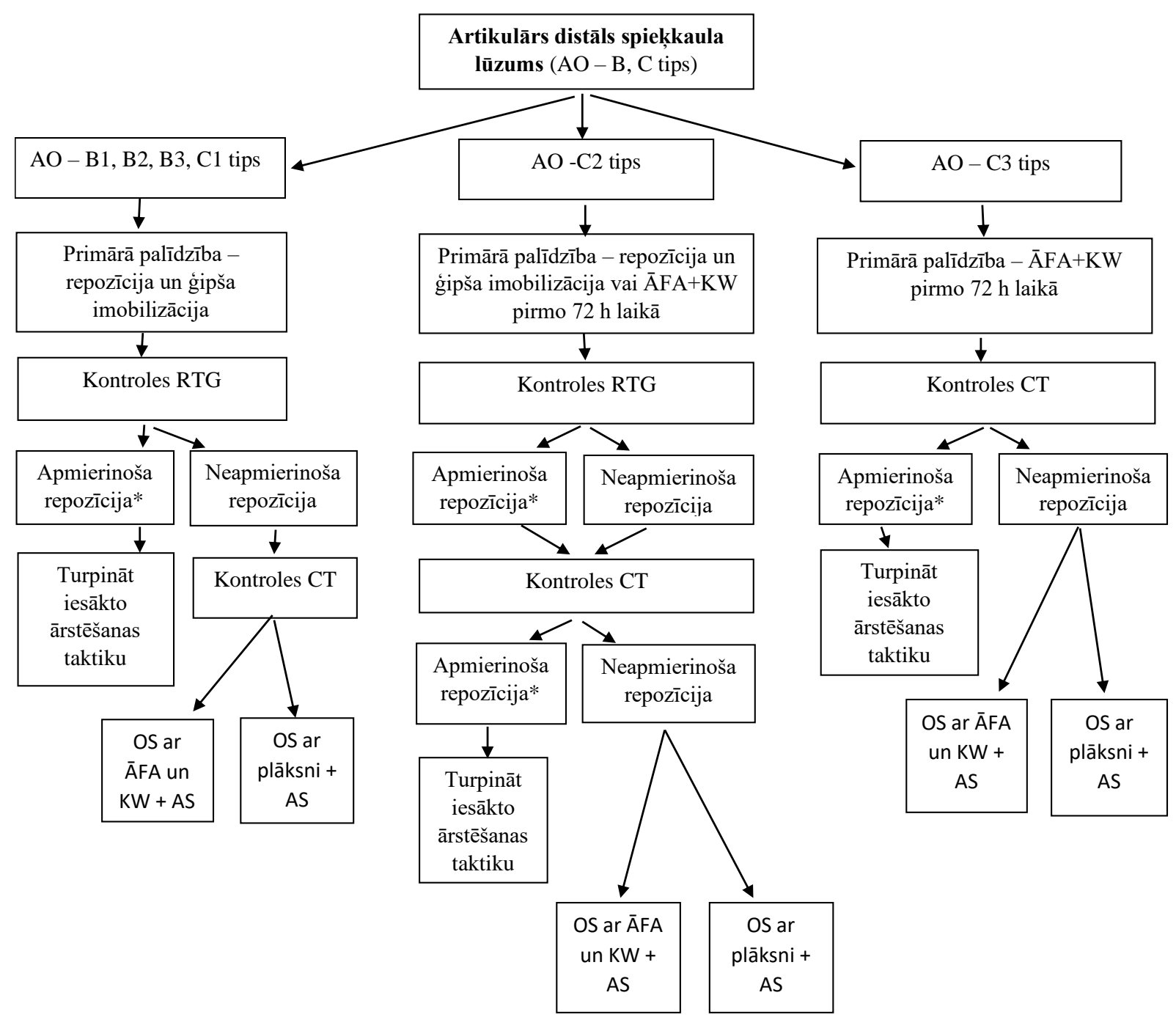

* Apmierinošas repoz̄̄ijas kritēriji: leṇku mērījumi - radiālā inklinācija, volārā pārkare, spieḳkaula augstums, elkoṇkaula galvinas pozīcija - ulna +, neitrāla vai ulna -, locītavu virsmu kongruence - distance vai pakāpiens mazāks par $1 \mathrm{~mm}$

Saīsinājumi: OS - osteosintēze, AS - artroskopija, ĀFA - ārējās fiksācijas aparāts, KW - Kiršnera stieple, CT komjūtertomogrāfija, RTG - rentgenogrāfija, AO - Arbeitsgemeinschaft für Osteosynthesefragen

Artroskopiski asistēta ostosintēze veicama stacionārā, kurā ir nepieciešamais tehniskais nodrošinājums, vēlams pirmo 7 dienu laikā pēc traumas 
10. pielikums

\section{RTG izmeklējuma veikšanas rekomendācijas}

Lūdzu veikt pacientam / -ei labās / kreisās (vajadzīgo apvilkt) plaukstas locītavas RTG izmeklējumus AP projekcijā $10^{\circ}-11^{\circ}$ leṇkị un LL projekcijā $20^{\circ}-22^{\circ}$ len,kīi.

Izmeklējumu veikt, pacientam esot sēdus pozīcijā ar sānu pret RTG galdu, pleca locītava pacelta vieglā abdukcijā un elkona locîtava saliekta $90^{\circ}$ leṇkī.

Ilustratīvie piemēri izmeklējuma pareizai veikšanai:

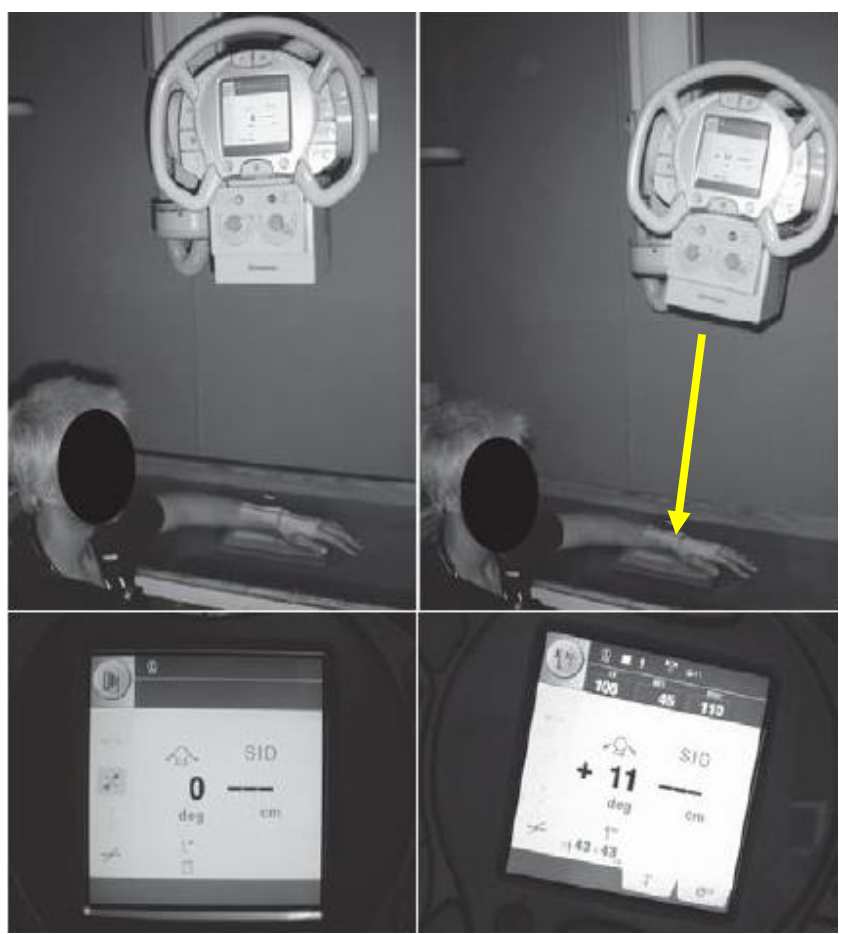

AP projekcija

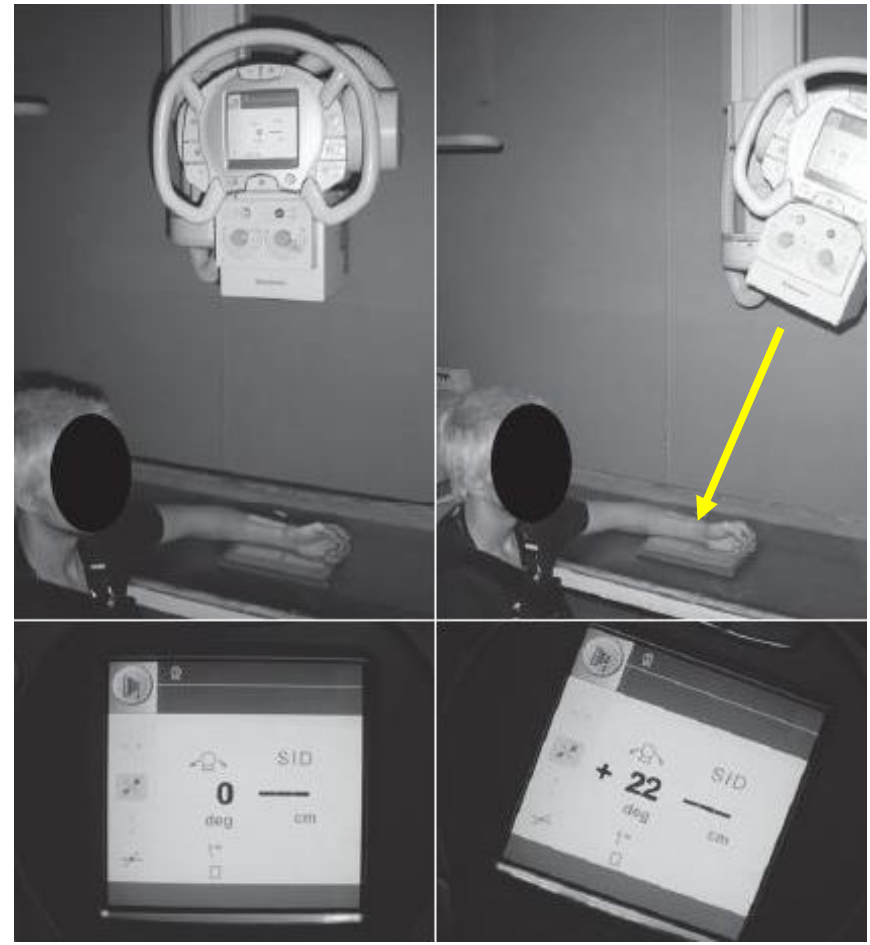

\section{LL projekcija}




\section{Patents}

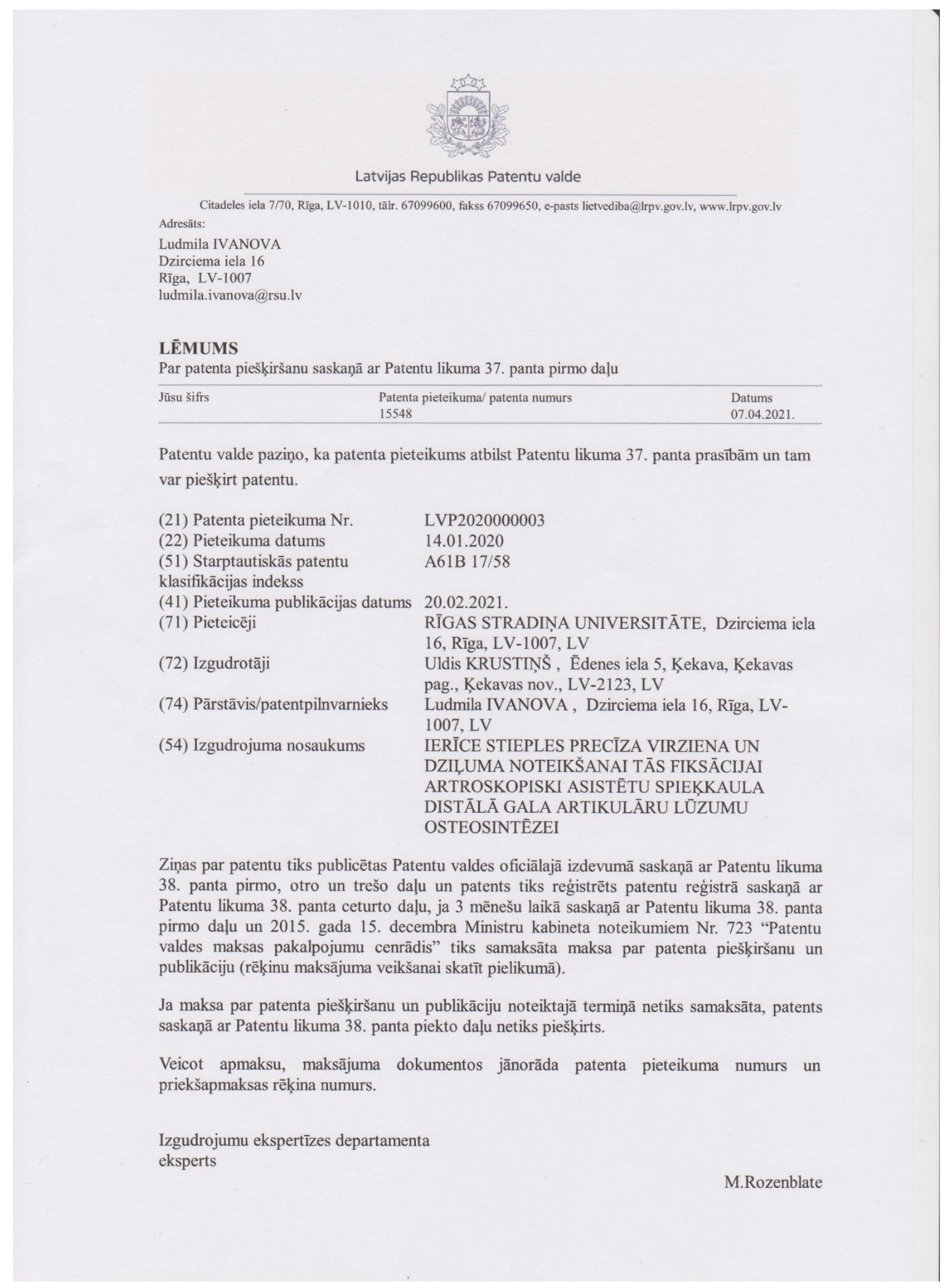

